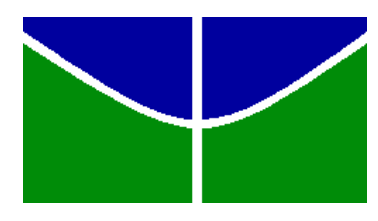

Universidade de Brasília - UnB

Programa de Pós-Graduação

em História - PPGHIS

\title{
A ATUAÇÃO DA JUSTIÇA EXPEDICIONÁRIA BRASILEIRA NO TEATRO DE GUERRA DA ITÁLIA (1944-1945)
}

WILLIAM PEREIRA LAPORT

BRASÍLIA/DF

2016 
WILLIAM PEREIRA LAPORT

\section{A ATUAÇÃO DA JUSTIÇA EXPEDICIONÁRIA BRASILEIRA \\ NO TEATRO DE GUERRA DA ITÁLIA (1944-1945)}

Dissertação de Mestrado apresentada ao Programa de Pós-Graduação em História da Universidade de Brasília, como parte dos requisitos necessários à obtenção do grau de Mestre em História.

Orientador: Prof. Dr. Francisco Monteoliva Doratioto

BRASÍLIA/DF

2016 


\section{Laport, William Pereira.}

A Atuação da Justiça Expedicionária Brasileira no Teatro de Guerra da Itália (1944-1945). /William Pereira Laport Brasília/DF, 2016.

$230 \mathrm{fls}$.

Dissertação de Mestrado apresentada ao Programa de PósGraduação em História da Universidade de Brasília - UNB, como requisito parcial para a obtenção do grau de Mestre em História. Orientador: Professor Doutor Francisco Doratioto.

1. $2^{\mathrm{a}}$ Guerra Mundial 2. Teatro de Operações da Itália.

3. Justiça Militar da FEB. 4. Condenações à Morte. 5. Indulto.

É concedida à Universidade de Brasília permissão para reproduzir cópias desta dissertação e emprestar ou vender tais cópias somente para propósitos acadêmicos e científicos. $\mathrm{O}$ autor reserva outros direitos de publicação e nenhuma parte desta dissertação pode ser reproduzida sem sua autorização, por escrito. 


\title{
A ATUAÇÃO DA JUSTIÇA EXPEDICIONÁRIA BRASILEIRA NO TEATRO DE GUERRA DA ITÁLIA (1944-1945)
}

Dissertação apresentada como requisito parcial para a obtenção do título de Mestre em História pelo Programa de Pós-Graduação em História da Universidade de Brasília - UnB.

Aprovado por:

Prof. Dr. Francisco Fernando Monteoliva Doratioto (Orientador) Universidade de Brasília - UnB

Prof. Dr. Thiago Tremonte de Lemos (Membro externo ao Programa ${ }^{1}$ ) Universidade de Brasília - UnB

Prof. Dr. Antônio José Barbosa (Membro externo ao Programa) Universidade de Brasília - UnB

Profa. Dr. Neuma Brilhante Rodrigues (Suplente)

\author{
BRASÍLIA/DF
}

2016

\footnotetext{
${ }^{1}$ Regulamento do Programa de Pós-Graduação em História. Art.20. A comissão examinadora para a defesa de dissertação de mestrado será:

I-composta e presidida pelo orientador e dois professores doutores, além de um suplente;

II- terá, pelo menos, um membro externo ao Programa.
} 
À minha querida mãe, Rita Laport (in memoriam) 


\section{AGRADECIMENTOS}

Agradeço ao Programa de Pós-Graduação em História da Universidade de Brasília pelo excelente curso oferecido, ao corpo docente por sua constante preocupação com a formação acadêmica dos alunos, e ao pessoal administrativo, que torna possível o dia- a- dia do curso de Mestrado em História.

Aos meus pais, Guiovaldo Laport e Rita Laport, exemplos de perseverança e retidão. A meu pai, por sempre depositar na educação a certeza da transformação da vida do homem. A minha mãe, pelo carinho, atenção, conforto e dedicação em nada menos que todos os momentos em que pude desfrutar de sua companhia.

À minha vó Ezy (em lembrança), pelo apoio permanente que me permitiu chegar até aqui.

À Paty, minha noiva, com quem tenho o privilégio de dividir as descobertas e experiências cotidianas, pelo carinho e compreensão; e por ter me ensinado a valorizar as conquistas já realizadas.

Gostaria de prestar meu sincero e profundo agradecimento ao Professor Francisco Fernando Monteoliva Doratioto, orientador desta dissertação, não apenas pelo trabalho árduo que comigo realizou para que, juntos, lográssemos concluir este estudo, mas principalmente pelo seu constante incentivo e pelas suas sábias orientações, que permitiram o aprimoramento do trabalho. 


\section{EPÍGRAFE}

"O Direito não é uma teoria, mas uma força viva. Por isso a Justiça sustenta numa das mãos a balança em que pesa o Direito e na outra, a espada de que se serve para defendê-lo. A espada sem a balança é a força bruta; a balança sem a espada é a impotência do Direito. Uma não pode avançar sem a outra, nem haverá ordem jurídica perfeita sem que a energia com que a Justiça aplica a espada seja igual à habilidade com que maneja a balança" (Rudolf von Ihering. A Luta pelo Direito) 


\section{RESUMO}

Quando a FEB foi organizada, a questão da Justiça em tempo de guerra exigiu alterações no sistema vigente, para adequar a legislação específica às contingências do envio de uma Força Expedicionária ao Teatro de Operações no além-mar. Assim, através do Decreto-lei $\mathrm{n}^{\circ}$ 6.678/44, foi criada a Justiça Militar da FEB, composta de um Conselho Supremo de Justiça Militar, um Conselho Militar e duas Auditorias. A partir da análise de seus julgados, constata-se que a maioria dos delitos foi praticada por pessoal do contingente da tropa em serviço de retaguarda ou depósito. Em um desses casos, duas sentenças da Justiça Militar foram proferidas dando a pena máxima: morte por fuzilamento. Acontece, porém, que a sentença tinha obrigatoriamente de ser comunicada ao Presidente da República que, valendo-se do sentimentalismo brasileiro, comutou a pena máxima para 30 anos de prisão, posteriormente reduzida, proporcionando aos condenados cumprir uma pena de apenas seis anos, antes de serem postos em liberdade. Em verdade, a maioria das sentenças proferidas pela Justiça Militar não foram cumpridas, pois o Governo, por meio do Decreto $\mathrm{n}^{\circ}$ 20.082/45, resolveu indultar a todos os oficiais e praças que, como integrantes da FEB, houvessem cometido crimes ou infrações que não de homicídio doloso ou deserção perante o inimigo. Os que ficaram de fora desse indulto, tiveram suas penas comutadas, o que causou um esvaziamento das funções desempenhadas por aquela Justiça especializada e um questionamento acerca de sua importância.

Palavras-chave: 1. $2^{\mathrm{a}}$ Guerra Mundial 2. Teatro de Operações da Itália. 3. Justiça Militar da FEB. 4. Condenações à Morte. 5. Indulto. 


\begin{abstract}
When the Brazilian Expeditionary Force ("FEB") was organized, the issue of wartime justice demanded changes in the current system to suit specific legislation to the contingencies of sending an expeditionary force to a theater of operations overseas. Thus, through the Decree-Law n. 6.678/44, the Military Justice of the FEB was established, comprised of a Supreme Council of Military Justice, a Military Council and two Military Courts. From the analysis of its sentences, it's noted that most of the crimes were committed by the personnel on rearguard force or deposit. In one of those cases, two capital trials resulted in death verdicts: death by firing squad. It turns out, however, that the sentence must had to be communicated to the President of Republic who, taking advantage of the Brazilian sentimentality, commuted the death penalty to 30 years of prison, later reduced, providing those convicts serving only a six years sentence, until they've been set free. In fact, most of the sentences of the Military Justice have not been met, because the Government, through de Decree n. 20.082/45, decided to pardon all officers and soldiers that had committed crimes or offenses other than murder or desertion in the presence of the enemy. Those who were left out of this pardon, have had their sentences commuted, which caused a stripping of the duties assigned to that specialized Justice, and a critical questioning about its importance.
\end{abstract}

Keywords: 1. World War II. 2. Theater of Operations from Italy. 3. Military Justice of Brazilian Expeditionary Force. 4. Death Penalties. 5. Pardon. 


\section{LISTA DE TABELAS}

Tabela 1: Da contribuição dos Estados para FEB

Tabela 2: Resumo da campanha da FEB na Segunda Guerra Mundial

Tabela 3: Composição do Supremo Tribunal Militar através dos tempos

Tabela 4: Quadro geral dos mortos na FEB por unidades

Tabela 5: Natureza dos crimes julgados pela Justiça Expedicionária

Tabela 6: Réus julgados pelas Auditorias Militares de campanha

Tabela 7: Quesitos do laudo de corpo de delito de Giovana Margelli

Tabela 8: Destaques das fichas funcionais de Adão Damasceno e Luís Bernardo

Tabela 9: Destaques do julgamento da Apelação no 21 pelo CSJM

Tabela 10: Casos análogos apenados de forma distinta 


\section{SUMÁRIO}

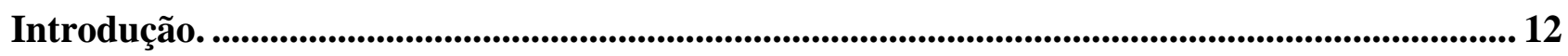

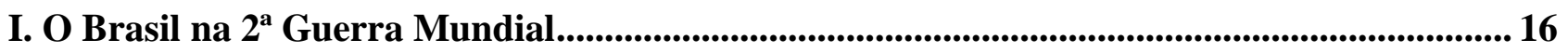

1.1. Do cenário internacional da Segunda Guerra Mundial ...................................................... 16

1.2 Da neutralidade à declaração de guerra. $O$ ingresso do Brasil no conflito....................... 22

1.3. A formação da Força Expedicionária Brasileira ................................................................. 31

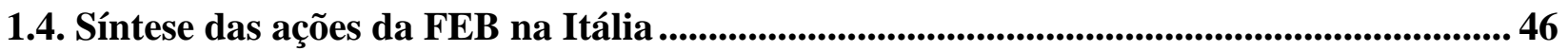

II. A Justiça Militar Brasileira ......................................................................................................... 53

2.1. Histórico da Justiça Castrense no Brasil .................................................................................. 55

2.2. A Justiça Militar no Estado Novo ............................................................................61

2.3. A criação da Justiça Militar Expedicionária .................................................................................. 65

III. A Atuação da Justiça Expedicionária no teatro operacional da Itália (1944/1945) ............ 70

3.1. Da organização da Justiça Castrense no teatro de operações ................................................ 70

3.2. Dos procedimentos processuais adotados pela Justiça Militar Expedicionária .............. 78

3.3. Visão panorâmica da atuação da Justiça Brasileira na Itália .......................................... 82

IV. Condenação à Morte: $\mathrm{O}$ caso Margelli....................................................................................... 111

4.1. Relato dos Acontecimentos ........................................................................................................... 111

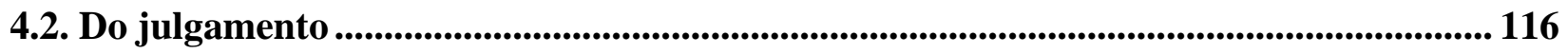

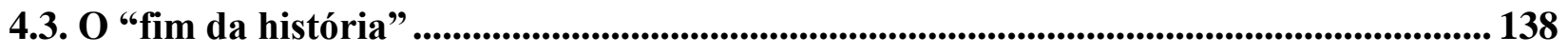

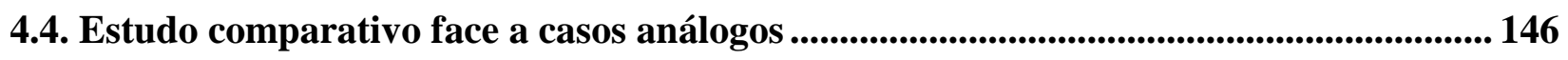

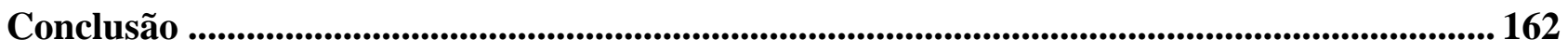

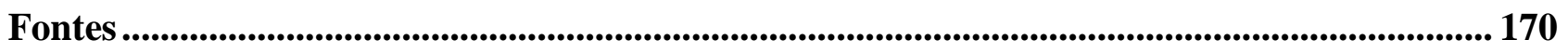

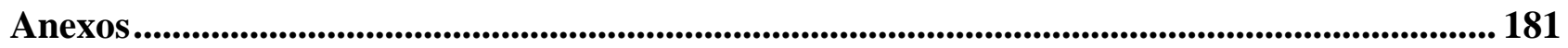




\title{
INTRODUÇÃO
}

\begin{abstract}
"Mesmo no quadro tormentoso da guerra, que é o recurso extremo e violento a que lançam mãos os homens para a solução dos conflitos internacionais, não se travariam combates e batalhas, e sim choques e encontros desordenados entre as facções ou hostes desenfreadas, se os exércitos em luta não se movessem dentro dos limites demarcados pelas regras e princípios regulamentares e os soldados individualmente não se submetessem à autoridade soberana da Lei". ${ }^{2}$ (General Mascarenhas de Moraes, Comandante da FEB).
\end{abstract}

A guerra é um assunto que apavora e encanta; desperta a curiosidade não só pelo fato em si, mas pela grandiosidade e abrangência do cenário e dos atores que envolvem tal acontecimento. Batalhas, heróis, causas e motivos, táticas de combates, tudo isso e muito mais, são aspectos que podem ser conhecidos e analisados em uma área da historiografia especializada denominada História Militar.

Contudo, deve-se ter em mente que a guerra não produz apenas heróis. Ela também constrói e desmascara atrocidades, embala pesadelos, dá visibilidade à mais vil e desumana parte do ser humano.

Isso porque, a guerra não é constituída somente de batalhas, mas, também, de incessantes horas de espera e vigília dos atores no front, o que remete à possibilidade da existência de um convívio social. Em relação à corporação militar, seus componentes interagem não só dentro do próprio corpo do exército, mas também com a população local onde estão alocados. Pode-se dizer então, que nestes cenários também são travadas outras batalhas nas quais tais populações recebem o rebatimento das condições físicas e emocionais dos militares. A população civil também acaba vítima do estado de guerra, de ações irracionais e patológicas que deixam marcas na história.

E assim, como em qualquer ambiente de convívio social, também é possível, e provável, a ocorrência de delitos, ou crimes propriamente ditos, tanto entre os membros do exército, quanto entre estes e a população local. E isto, não raro, ocorreu durante a $2^{\mathrm{a}}$ Guerra Mundial.

\footnotetext{
${ }^{2}$ Nota de Comandando, datada de 20 de abril de 1945. In: MASCARENHAS DE MORAES, João Baptista. A FEB pelo seu Comandante. Rio de Janeiro: Biblioteca do Exército Ed., 2005.
} 
O falecido jornalista Joel Silveira, correspondente de guerra brasileiro na Itália, deixou registrado em documentário ${ }^{3}$ produzido pelo repórter Geneton Moraes Neto, no qual demonstrou que na retaguarda dos conflitos as brutalidades podem ser piores do que na frente de combate. E realmente ele tinha razão.

O debate contemporâneo acerca da temática se vale da interlocução com várias áreas do conhecimento- Direito, Sociologia, Antropologia, Psicologia, Geografia, Política, Economia, História Contemporânea, e vem subsidiar a História Militar com dados e fatos que promovem o complemento da "História Oficial".

O compromisso do acadêmico nessa área do conhecimento reside em desvendar os acontecimentos e os fatos em suas diferentes dimensões, a fim de que os que o sucedam possam criar alicerces de verdades em suas condições de existência.

Assim, considera-se fundamental destacar tanto os feitos heroicos dos batalhões, e não foram poucos os êxitos obtidos pela Força Expedicionária Brasileira ("FEB") em combate no teatro de operações da Itália, bem como trazer à tona e ao conhecimento geral, crimes que foram cometidos por estes soldados em solo estrangeiro, na qualidade de representantes da nação na defesa de um ideal.

Em verdade, inúmeros foram os estudos, livros e trabalhos acadêmicos que já trataram da participação do Brasil na Segunda Guerra Mundial. No entanto, apesar das profundas abordagens realizadas por renomados historiadores, ainda restam passagens pontuais no referido conflito que merecem maiores esclarecimentos.

Dentre elas, destaca-se a atuação da Justiça Militar Expedicionária Brasileira, composta de advogados de ofício, promotores e juízes, a fim de acompanhar praças e oficiais da FEB, competindo-lhes, no próprio teatro de guerra em que os pracinhas brasileiros combatiam, aplicar e executar o ordenamento jurídico brasileiro.

O estudo da Justiça Militar na Campanha da Itália, por conseguinte, é de extrema importância, pois reflete a realidade brasileira e sua conjuntura histórica na $2^{\mathrm{a}}$ Guerra Mundial. O interesse acadêmico reside no estudo da aplicação e execução do sistema jurídico brasileiro, em tempo de guerra, com ênfase na pesquisa de fontes

\footnotetext{
3 Documentário: "Garrafas ao mar: a víbora manda lembranças". Disponível em: https://archive.org/details/GarrafasAoMar (acesso em 22.09.2016).
} 
históricas, com o fito de compreender o quão relevante foi a atuação dessa Justiça Especializada junto à FEB.

Com esta perspectiva, o problema enfrentado na presente dissertação consiste na análise da atuação da Justiça Militar Expedicionária Brasileira no Teatro de Guerra na Itália, durante a $2^{\mathrm{a}}$ Guerra Mundial, e ao tratamento por ela dado aos crimes cometidos pelos pracinhas brasileiros que compunham a FEB, analisando-se, em destaque, suas razões de decidir ao sentenciar a pena de morte, única naquela campanha, a dois combatentes brasileiros, ante a acusação de crime sexual, mais especificamente a violência carnal e homicídio cometido para garantir a execução do primeiro delito, bem como os motivos que levaram esta Justiça especializada a julgar demais delitos semelhantes de forma diferenciada.

Hockett ${ }^{4}$ defende que - "a revisão crítica dos dados reunidos é o passo mais importante na pesquisa histórica"--, já que o historiador deve utilizar-se de "escritas carregadas de interpretações", o que deve configurar na capacidade do investigador -- "de reconhecer a objetividade do fato"--.

Nesse sentido, em referência ao quadro teórico-metodológico empregado, tendo em vista a natureza das variáveis a serem trabalhadas, foi conduzida uma pesquisa descritiva e explicativa, com a finalidade de elucidar a atuação da Justiça Militar Expedicionária Brasileira na Itália, tendo em mente que - "não se pode pretender formular leis gerais em história, porque elas se reduziriam a banalidades; é preciso, em vez disso, contentar-se com explicações racionais"

A metodologia de pesquisa adotada residiu na condução de um estudo interdisciplinar, sobretudo junto à área acadêmica do Direito, a fim de melhor abordar a temática retratada, bem como em pesquisa bibliográfica e documental, em acervos das bibliotecas do Rio de Janeiro, Brasília e de Instituições e Tribunais Militares, destacandose, como de maior valia, o Arquivo Histórico do Exército (“AHEx"), localizado no Palácio Duque de Caxias ("PDC"), no Rio de Janeiro e o Arquivo do Superior Tribunal Militar (“STM”), em Brasília.

Isto posto, define-se para a pesquisa ${ }^{6}$ a Itália, como área geográfica; o tempo considerado como o período da participação do Brasil na Segunda Guerra Mundial, entre os anos de 1944 e 1945; a atividade humana em foco como sendo os crimes perpetrados

\footnotetext{
${ }^{4}$ RICHARDSON, R.J. Pesquisa Social Métodos e Técnicas. $3^{\text {a }}$ Edição. São Paulo: Atlas S.A., 1999. p. 249.

${ }^{5}$ DRAY, William. Laws and Explanations in History. Londres: Oxford University Press, 1957.

${ }^{6}$ RICHARDSON, p. 249.
} 
pelos combatentes brasileiros naquele teatro de operações, destacando-se as violências carnais e homicídios e; quantos às pessoas envolvidas, considera-se não só os soldados e as vítimas, mas também todas as autoridades julgadoras, representantes das leis brasileiras em território estrangeiro.

O trabalho foi estruturado em quatro capítulos.

O capítulo I realiza uma breve contextualização dos cenários internacional e nacional que preconizaram a $2^{\mathrm{a}}$ Guerra Mundial, demonstrando como o Brasil foi da neutralidade à declaração de Guerra, bem como destrinchando de que forma se deu a formação da FEB, estruturada à luz da Portaria ministerial n. 4.744/43, além de apresentar uma breve síntese da ação militar brasileira no teatro de guerra da Itália.

O capítulo II trata, especificamente, da Justiça Castrense, oferecendo um breve histórico desde sua criação, perpassando por sua presença ao longo das Constituições brasileiras, sua participação no Estado Novo de Vargas e de que forma foi estabelecida a Justiça Militar Expedicionária brasileira.

O capítulo III expõe de que forma se deu a organização da Justiça Expedicionária no teatro de operações e busca materializar a ação dessa Justiça Especializada, oferecendo uma "visão panorâmica" de sua atuação, através de suas ações, seus julgamentos, crimes analisados e estatísticas de seus trabalhos.

O capítulo IV apresenta o percurso de toda a marcha processual do único caso sentenciado com a pena capital, depois de instaurada a República, perpassando em detalhes as circunstâncias fáticas e processuais que permearam a ação penal. Busca-se tracejar, ainda, um estudo comparativo face aos demais casos análogos julgados pela Justiça Expedicionária, buscando compreender o porquê de este ser o único sentenciado à pena de morte.

Finalizam este trabalho as Considerações Finais, apontando que em dezembro de 1945, o Governo Brasileiro, por meio do Decreto n. 20.082 (Anexo n. 7), houve por bem indultar todos os oficiais e praças que, como integrantes da FEB, tivessem cometidos crimes, que não de homicídio doloso ou deserção perante os inimigos, o que causou um "esvaziamento" das ações da Justiça Expedicionária. Seguem-se as Referências Bibliográficas e os Anexos, que enriquem e suportam a dissertação. 


\title{
I. O BRASIL NA 2a GUERRA MUNDIAL
}

\author{
"A guerra faz o Estado e o Estado faz a guerra". (TILLY, Charles. How \\ war made states, and vice versa. In: Coercion, Capital and European \\ States AD 990-199, Cambridge (Mass.): Blackwells Publishers, 1992).
}

\section{(i) Do cenário internacional da Segunda Guerra Mundial.}

Entre 01 de setembro de 1939 e 02 de setembro de 1945, o mundo viveu um dos maiores confrontos bélicos retratados na história humanidade, a Segunda Guerra Mundial.

Buscando as raízes maiores da luta, não há como se distanciar da inquietante fase que a antecedeu. O silenciar das armas, com a paz imposta pelo Tratado de Versalhes (1919) ao término da Primeira Guerra Mundial, não representou a conciliação dos interesses nacionais em jogo. Em verdade, dados os termos impostos pelo Tratado de Versalhes, a paz não podia ser duradoura: levava em si o estopim de uma nova guerra e era de se prever que esta, mais cedo ou mais tarde, seria deflagrada.

Fatores como o não cumprimento dos princípios de igualdade dispostos naquele tratado; a parcialidade com a qual a Liga das Nações atuava em prol das potências "vencedoras"; o revanchismo adotado pelos "vencedores", em contrapartida ao rancor estabelecido nas nações "vencidas", que responderam a severas sanções; a criação artificiosa de certos Estados, como a Tchecoslováquia e a engrandecida Sérvia (transformada em Iugoslávia), a despeito de toda lei geográfica e étnica estabelecida naquela localidade; o estabelecimento de anomalias geopolíticas, como o Corredor de Dantzig e; a subida ao poder, em alguns países, de governos de caráter belicoso, fizeram dos vintes anos subsequentes ao Tratado de Versalhes, um tempo de contínuo sobressalto e angustiante expectativa.

Arvoraram-se, assim, regimes políticos em arautos de novos tempos em que a redenção do homem assentava-se na grandeza de uma raça ou na hegemonia social de uma classe. Mobilizando crescente poderio bélico para a implantação de Estados militaristas e consecução de intuitos expansionistas, com forte apelo nacionalista, um bloco de países regidos por líderes totalitários (Alemanha, Itália e Japão) promoveu crises que levaram as nações a um clima de intimidações. 
No processo histórico, é tarefa por demais complexa encontrar um único responsável, um motivo preponderante pela nova guerra. Diante da crise mundial que se manifestava, aspirações imperialistas desempenharam papel significativo, razão pela qual, a força motriz da deflagração da Segunda Guerra Mundial pode levar a um estudo das relações internacionais do imperialismo, com o consequente crescimento do nacionalismo e o desenvolvimento da indústria bélica.

Nada obstante, ainda mais decisiva foi a vontade de hegemonia de Adolf Hitler diante do governo da Alemanha, visando construir uma nova ordem conforme os princípios do nazismo, o que deu à guerra a dimensão de uma cruzada pela nova civilização.

Grande parte da nação alemã repudiava a derrota imposta pelas armas, inaceitável para o orgulho da pátria. O inconformismo e a frustração provocaram um ressentimento nacional, exacerbado pelo Tratado de Versalhes, que o povo alemão chama de "Versailles Diktat".

Esse desapontamento agravou-se ainda mais com o caos econômico em que mergulhou o país, uma hiperinflação até hoje estudada e citada como modelo clássico.

Assim, em uma atmosfera de grande depressão, causada, sobretudo, pelos efeitos da crise de 1929 sobre a economia alemã - entre eles uma inflação descontrolada e o desemprego em massa -, chegou ao poder em 1933, sob a liderança de Hitler, o Partido Nacional Socialista da Alemanha, implementando o que ficou marcado na história como o "III Reich"7.

Com efeito, o Reichswher, exército alemão consentido pelo Tratado de Versalhes, tornou-se um núcleo de profissionais altamente competentes que se preparou, se aperfeiçoou e, através de uma análise do que ocorrera na I Grande Guerra, elaborou novas técnicas e estratégias para uma próxima guerra.

O núcleo de oficiais do Reichswehr organizou, pacientemente, uma formidável máquina militar, que passou a ser conhecida e temida em todo o mundo, com o nome de Wehrmacht e criou uma tendência favorável para a implantação de um Governo forte e totalitário $^{8}$.

\footnotetext{
${ }^{7}$ Chamou-se III Reich porque havia o I Reich (o Sacro Império Romano Germânico que Oton I fundou em 962 e durou até 1806); e o II Reich, nascido em 1871 sob Guilherme I, com a unificação alemã.

${ }^{8}$ SILVEIRA, Joaquim Xavier da. A FEB por um soldado. Rio de Janeiro: Biblioteca do Exército, 2001. p. 23 e 24.
} 
Apoiado na ideologia anti-semita do nazismo, o programa de governo ${ }^{9}$ de Hitler visava a recuperação econômica e militar da Alemanha, através da reorganização das Forças Armadas e ao desenvolvimento da produção de armamentos; bem como a revisão dos termos do combatido Tratado de Versalhes, assinado por ocasião da Conferência de Paz de Paris de 1919.

França e Inglaterra, a seu turno, desejavam manter uma política nãointervencionista na Europa, a fim de evitar qualquer desgaste que desatasse em um novo confronto armado.

Não por outro motivo, ambas as nações se mantiveram inertes diante da guerra civil espanhola (1936-1939), envolvendo fascistas espanhóis e republicanos, da qual decorreu a implementação de um Estado de característica fascistas na Espanha- o 'Fascismo'; e foi essa a mesma reação que adotaram ante as reivindicações territoriais de Hitler, numa política conhecida como “appeasement” (política de expansão territorial).

Valendo-se da omissão das nações europeias que tinham se sagrado vencedoras na Primeira Guerra Mundial, a Alemanha nazista agiu, enviando tropas à zona desmilitarizada do Reno; incorporando a Áustria em 1938 (Anschluss); e ocupando a região dos Sudetos, na Tchecoslováquia, através dos Acordos de Munique de 1938, firmados entre Alemanha, Itália, França e Inglaterra.

Houve então a primeira grave advertência: o Governo inglês, chefiado pelo pacifista Chamberlain, comunicou ao Governo do III Reich que aquela seria a última reivindicação territorial tolerada. A Inglaterra e a França assinaram, em 25 de agosto de 1939, um tratado com a Polônia, que figurava, provavelmente, como próximo alvo do expansionismo nazista ${ }^{10}$.

Contudo, após a assinatura do pacto de não-agressão junto à União Soviética (pacto Ribbentrop-Molotov), beneficiando a Alemanha ao evitar uma possível guerra em duas frentes (oriental e ocidental), a política externa expansionista implementada por Hitler teve continuidade com a invasão da metade ocidental da Polônia, iniciada em $1^{\circ} \mathrm{de}$ setembro de 1939.

\footnotetext{
${ }^{9}$ Em verdade, o novo Reich buscou o desenvolvimento com base em planos quadrienais. No Primeiro Plano, iniciado em 1933, realizaram-se obras públicas para absorver desempregados: aeroportos, estradas, ferrovias, tudo com finalidade estratégica. O desemprego desapareceu em 1937. Mas o grande trunfo estava no desenvolvimento secreto da indústria bélica, que provocou a retomada industrial. O Segundo Plano Quadrienal, a partir de 1936, tinha por finalidade libertar a Alemanha de matérias-primas importadas. Em 1939, a indústria alemã é a segunda do mundo. Mas faltam minérios para a siderurgia. A agricultura fornece $75 \%$ do que o país precisa. A indústria bélica exige mais e mais matéria-prima. Havia, então, limites para essa autarquia- essa autossuficiência econômica. A acumulação de estoques levaria necessariamente à tese expansionista, à busca do espaço vital. Essa necessidade vinha a calhar para a propaganda nazista em torno da questão nacional.

${ }^{10}$ SILVEIRA, p. 25.
} 
França e Inglaterra não poderiam se manter inertes diante da invasão da Polônia, na medida em que ambos haviam assumido um compromisso de garantir a integridade territorial polonesa. Dessa forma, dois dias depois da invasão alemã à Polônia, França, Inglaterra, Austrália e Nova Zelândia declararam guerra à Alemanha, dando início à Segunda Grande Guerra, na Europa.

O Brasil mantinha sua neutralidade, propalada pelo Decreto-Lei n. 1.361/39, que anunciava o --“"resguardo de sua neutralidade na guerra entre potências estrangeiras não americanas" $" 11$--.

Não demorou muito para que outros países europeus, alvo da política de ocupação alemã, se vissem envolvidos no conflito. Foi o que aconteceu, no ano de 1940, com Dinamarca e Noruega (09 de abril), Bélgica, França, Luxemburgo e Países Baixos (10 de maio), a expulsão dos ingleses de Dunkerque (04 de junho) e a rendição da França, em 25 de junho daquele ano; todos vítimas do poderio nazista implementado pela política externa hitlerista ${ }^{12}$.

A União Soviética, que até então vinha adotando uma posição de quase aliança com a Alemanha (pacto Ribbentrop-Molotov), terminou por declarar guerra a esse país após ter seu território atacado pelos alemães em junho de 1941.

Foi também em 1941, em resposta ao ataque sofrido em sua base militar de Pearl Harbor, em 07 de dezembro daquele ano, que os Estados Unidos decidiram intervir no conflito em desfavor da Alemanha nazista e seus aliados, transformando uma guerra europeia em um conflito mundial ${ }^{13}$.

Nesse meio tempo, em outra parte do globo, o Japão buscava a constituição da "Grande Ásia”, anexando a Manchúria e outras regiões da China, respaldado em seu alinhamento junto à Alemanha, que se dera com a assinatura do Pacto Anti-Komintern, em janeiro de 1936.

Da mesma forma a Itália, sob o signo do fascismo implantado por Mussolini, conquistara a Abissínia (Etiópia) e a Albânia. Igualmente decidira apoiar o governo de Hitler, com base no Pacto Ítalo-Germânico de março de 1936, formando o eixo RomaBerlim, a ser combatido.

\footnotetext{
${ }^{11}$ Carlos Eduardo Franco Azevedo, Gláucio Érico de Almeida Silva, Eros José Sanches (organizadores). 5 Batalhão de engenharia de combate blindado: 100 anos de história - Tomo II - União da Vitória (PR): UNIUV, 2015.

${ }^{12}$ Idem. p. 194.

${ }^{13}$ SILVEIRA, p. 259.
} 
Essa foi, portanto, a configuração do maior conflito bélico da história contemporânea, com duração oficial de seis anos, considerando-se a invasão da Polônia, em $1^{\circ}$ de setembro de 1939 e a rendição japonesa no dia 2 do mesmo mês, no ano de 1945.

De um lado, viu-se disposto um bloco de países regidos por líderes totalitários, denominado forças do Eixo, que almejava o expansionismo através da força, criando uma tirania global. Do outro, as potências democráticas - dentre as quais destaca-se França, Inglaterra, EUA e, mais tardiamente o Brasil, com ajuda decisiva da ex-União das Repúblicas Socialistas Soviéticas (URSS) comunista, lutavam para defender a soberania de sua aliança, detendo a marcha do nazi-fascismo.

Em breve escorço do desenrolar operacional do conflito, pode-se afirmar que, até cerca de junho de 1942, a guerra se caracterizou pela expansão vitoriosa das forças do Eixo, com a crescente ocupação de territórios nas mais diversas partes do globo.

Dessa forma, a primeira fase da guerra foi marcada pela vitória do Eixo- de 1939 a meados de 1942. A Alemanha adotou a "blitzkrieg"- guerra relâmpago, que consistia numa tática de operação combinada (naval, aérea e terrestre).

Nessa primeira fase, a Alemanha ocupou a Polônia, Dinamarca, Noruega, Holanda, Bélgica e França. A França, após a invasão, ficou dividida em duas áreas: uma zona de ocupação pelos nazistas e uma zona "livre", governada pelos simpatizantes do nazismo.

Em 1941 o Eixo recebeu o apoio da Hungria, Romênia e Bulgária, ocasião em que houve a ocupação da Iuguslávia e da Grécia. No mesmo ano houve o desembarque da Afrikakorps (comandada por Rommel) com o objetivo de conquistar o canal de Suez.

Contudo, entre os anos de 1941 e 1943 houve um período de equilíbrio entre as forças na guerra. Em junho de 1941 a Alemanha deu início à Operação Barbarrosa- a partir da qual ocorreu a invasão da União Soviética, incialmente exitosa, mas que, dado o longo período pelo qual perdurou, fora responsável pela inversão do fluxo de combate, fazendo a Wermacht recuar.

Em dezembro de 1941, conforme destacado anteriormente, o Japão atacou a base naval americana de Pearl Habor, durante seu expansionismo pela Ásia, fato que marcou a entrada dos Estados Unidos no conflito, e a virada definitiva em favor dos Aliados.

A partir de então, até fevereiro de 1943, deu-se a contenção do expansionismo do Eixo e deflagrou-se o início da contraofensiva dos Aliados. 
Entre 1943 e 1945 a guerra decorreu, enfim, no sentido da vitória das forças contrárias ao Eixo.

A Batalha de Stalingrado, vencida pelos comunistas, marca o início da derrocada dos nazistas; em 1944 inicia-se a Operação Overlord (Dia D) e o desembarque dos aliados na Normandia.

A Overlord, nome código da invasão da Normandia, envolveria um contingente nunca antes visto numa operação militar durante a II Guerra até aquele momento. Seriam mais de 4 mil embarcações envolvidas, sendo que 213 eram navios de guerra, como encouraçados e cruzadores- além de 13 mil aviões de diversos tipos.

No desembarque inicial, 5 Divisões de infantaria e de blindados inglesas, norte-americanas e canadenses estariam responsáveis pelo assalto às cinco praias escolhidas na Baia do Sena. Haveria, ainda, o assalto de três divisões aerotransportadas, duas norte-americanas e uma inglesa, atrás das linhas inimigas, em pontos estratégicos.

Nos dias seguintes à invasão seriam desembarcadas mais divisões, compondo dois Exércitos, o I Exército Americano e o II Exército Britânico. Para compor essas unidades foram deslocadas Divisões que atuavam em outros fronts. Algumas unidades do VIII Exército Inglês e do V Exército Americano que formavam as forças aliadas na Itália foram cedidas à Overlord.

A invasão da Normandia seria complementada por outra ação ao sul da França, a Operação Anvil. A 15 de agosto de 1944, o VII Exército Norte-Americano, apoiado por 9 porta-aviões e mais de 800 embarcações variadas desembarcaram Forças entre Toulon e Cannes. Mais uma vez unidades experientes foram deslocadas de outras frentes de batalha, incluindo a Itália.

\footnotetext{
"Essencialmente, as forças que dela participam provém do desmembramento do exército da Itália. A 28 de julho, em plena perseguição, depois da tomada de Livorno, Pisa e Siena, o $6^{\circ}$ Corpo norte-americano e o Corpo expedicionário Francês foram retirados do general Clark e levados ao Sul da Itália para serem desembarcados com destino à costa provençal"14.
}

É neste contexto, no âmbito estratégico, que deve ser entendida a participação da FEB no V Exército Norte-Americano, no teatro operacional da Itália, ao longo do conflito mundial, o qual será melhor abordado nos capítulos subsequentes.

Em 1944 os brasileiros foram ao teatro de guerra europeu a fim de cobrir claros deixados pelas unidades que eram deslocadas para as ações na França, combatendo

\footnotetext{
${ }^{14}$ CARTIER, Raymond. A Segunda Guerra Mundial. Rio de Janeiro: Larousse do Brasil- Paris Match, 1967, p. 622.
} 
em um país que já havia se rendido aos Aliados desde setembro de 1943, com a assinatura de um acordo de paz em separado, embora tropas alemãs permanecessem em seu território.

Em 07 de maio de 1945 o governo alemão capitulou, pondo fim à guerra na Europa.

Finalmente, em 14 de agosto daquele mesmo ano, o Japão se rendeu às forças aliadas, em seguida ao lançamento, pelos Estados Unidos, de duas bombas atômicas sobre as cidades de Hiroshima e Nagasaki, causando enorme destruição.

O conflito bélico envolveu diretamente 29 países e, durante os seis anos de guerra, estima-se a perda de 50 milhões de vidas, entre militares e civis, nos diversos teatros de operações ${ }^{15}$. Destes, importante não olvidar, mais de cinco milhões de judeus foram exterminados em campos de concentração nazistas, como parte da política antisemita implementada por Hitler.

\section{(ii) Da neutralidade à declaração de guerra. O ingresso do Brasil no conflito.}

Com exceção de quem viveu à época, pouco se sabe, nos dias de hoje, do impacto da Segunda Guerra Mundial no cotidiano do povo brasileiro. A maioria dos livros de história costuma restringir a participação do Brasil às batalhas da Itália ao lado dos americanos. Contudo, a decisão de Getúlio Vargas sobre que lado o país deveria assumir no conflito, o dos Aliados ou o dos países do Eixo, não foi tomada de um dia para o outro, mas construída em um processo político lento e tortuoso, iniciado anos antes do conflito estourar na Europa, em 1939.

Em novembro de 1930, após perder as eleições para Júlio Prestes, Getúlio Vargas foi alçado ao poder pela Junta Militar Provisória, que depôs o presidente Washington Luís 22 dias antes do término do mandato, através de um movimento armado de cunho corporativista denominado tenentista ${ }^{16}$.

Inspirado até certo ponto pela filosofia positivista, segundo Nelson Werneck Sodré $^{17}$, o tenentismo era -“superficial (...) e modesto em suas reivindicações. Começava por supor que tudo dependia dos homens que estavam no poder e que a simples substituição deles levaria a resultados significativos"--.

\footnotetext{
${ }^{15}$ Teatro de Operações é o terreno onde se realizavam as operações militares durante as Guerras.

${ }^{16}$ SKIDMORE TE. Brasil: Getúlio Vargas a Castelo Branco (1930-1964). $7^{\text {a }}$ ed. Rio de Janeiro (RJ): Paz e TERRA; 1996.

${ }^{17}$ SODRÉ, Nelson Werneck. Formação histórica do Brasil. $5^{\text {a }}$ ed. São Paulo: Editora Brasiliense, 1969.
} 
O país, com aproximadamente 37 milhões de habitantes à época, passava por uma grave crise econômica e social decorrente dos reflexos da quebra dos mercados financeiros internacionais de 1929. Caíram dramaticamente as exportações do então principal produto brasileiro, o café, e o balanço de pagamentos estava bastante deficitário.

As classes dominantes cindiram-se, e os políticos fora do eixo tradicional do poder, situado em São Paulo e Minas, uniram-se para mais um levante militar ${ }^{18}$. Assim, em 03 de novembro de 1930, Getúlio Vargas, líder do movimento, entrou no Rio de Janeiro à frente das tropas revolucionárias comandadas pelo general Góis Monteiro, declarando estar -“assumindo provisoriamente o governo da República, como delegado da Revolução, em nome do Exército, da Marinha e do Povo", ${ }^{19--}$.

Nomeado Chefe Provisório da República (os revolucionários não aceitavam o título de presidente), Getúlio Vargas passou pelo governo provisório (1930-1934) e pelo governo constitucional (1934-1937), apoiado por militares e pela população. Não tardou para que, ante a ameaça de um falso plano comunista para tomada do poder (Plano Cohen), Vargas implantasse um novo regime político, caracterizado pela centralização, pelo nacionalismo, anticomunismo e por um irrestrito autoritarismo ${ }^{20}$.

Assim, na manhã de 10 de novembro de 1937, Getúlio deu um putsch, um autogolpe, baixando decreto que suspendia as garantias constitucionais e dissolvia o Congresso Nacional por ação da Polícia, a fim de evitar a presença ostensiva do exército ${ }^{21}$. Às dez horas do dia seguinte, foi assinada nova carta constitucional ${ }^{22}$, conhecida mais tarde como "Polaca", minutada em sua maior parte por Francisco Campos $^{23}$, homem com fortes inclinações fascistas, dando início, assim, ao denominado Estado Novo $^{24}$ (1937-1945), no qual Getúlio assumiu todo o poder para si próprio, governando por meio de decreto ${ }^{25}$.

Getúlio demorou a definir o rumo ideológico de seu governo. Como ditador de um país de dimensões continentais na América do Sul, Vargas nutria grande admiração

\footnotetext{
${ }^{18}$ Idem. p. 320.

${ }^{19}$ BASBAUM, Leôncio. História sincera da República. V. III. São Paulo: Alfa-Omega, 1976.

${ }^{20}$ BRANDI, Paulo. Vargas: da vida para a história. Rio de Janeiro: Zahar, 1983, p. 03.

${ }^{21}$ FAUSTO, Boris. Getúlio Vargas. São Paulo: Companhia das Letras, 2006. p. 80 e ss.

22 A Constituição Federal de 1937 tinha muitas semelhanças com o tipo de governo que existia na Itália, contendo artigos semelhantes aos que existiam no regime fascista de Benito Mussolini. Fonte: MONTEIRO, Marcelo. U-507: o submarino que afundou o Brasil na Segunda Guerra Mundial. Santos-Salto, SP: Schoba, 2012. p. 26.

${ }^{23}$ Francisco Campos, ministro da Justiça de 1937 a 1941, autor da Constituição estadonovista, teceu elogios a Hitler, em livro, comentando efusivamente o avanço histórico do totalitarismo, afirmando que -"não há hoje um povo que não clame por um César"--. A obra referida é 'O Estado Nacional, sua estrutura, seu conteúdo ideológico', lançado em 1940. ${ }_{24}$ Que segundo Thomas E. Skidmore -"representava a versão brasileira abrandada do método fascista europeu"-.SKIDMORE, p. 283.

${ }_{25}$ BURNS, E. Bradford. A History of Brazil. 3ed. Nova York: Columbia University Press, 1993.p. 356-ss.
} 
pelos regimes ditatoriais da Europa. Por essa razão, em 1931, recebeu Italo Balbo, jovem comandante da aviação italiana e um dos mais truculentos seguidores do líder fascista Benito Mussolini, no Palácio do Catete.

O encontro, tratado com grande festividade, aproximou Vargas de Mussolini em uma parceria que vigoraria pelos 11 anos seguintes.

Em paralelo, a idolatria por Hitler crescia na Alemanha e entre aliados importantes do governo brasileiro, que fazia vista grossa para as atividades do Partido Nazista no país. A seção fundada em 1928, em Timbó, Santa Catarina, amealhava legalmente seguidores na comunidade germânica. A simpatia pela causa nazifascista era tamanha que chegou à constituição brasileira promulgada por Vargas em 1934, a "Polaca".

Preocupado com o avanço do nazismo na América Latina ${ }^{26}$, em 1936, o presidente americano Franklin Delano Roosevelt estendeu sua política de boa vizinhança e visitou Getúlio no Rio de Janeiro. A empatia entre os dois foi imediata, o que favoreceu a construção de parceria junto aos americanos, em troca de certos benefícios econômicos.

Nada obstante, a situação econômica e financeira do Brasil se deteriorava de forma substancial, uma vez que o déficit do balanço de pagamentos crescia em decorrência da queda dramática do saldo da balança comercial, consequência da diminuição dos preços internacionais das mercadorias agrícolas. Foi então que, em 1938, Getúlio Vargas declarou a moratória unilateral da dívida externa, o que fez o Brasil perder acesso aos mercados financeiros voluntários internacionais ${ }^{27}$.

\footnotetext{
${ }^{26}$ Num dos capítulos do livro 'Hitler m'a dit' (Hitler me disse), escrito por um dos seus mais íntimos colaboradores- o ex-oficial prussiano Hermann Rauschning, que combatera na Primeira guerra e, em 1932, se filiara ao Partido NacionalSocialista-, está reproduzida uma conversa dele com o ditador, ocorrida em 1934, da qual participou também um convidado que acabara de chegar da América do Sul. Nela, se comprovava que os planos de Hitler de estender os seus domínios até a América Latina, e especialmente ao Brasil, eram reais e para lá de ambiciosos: "O Brasil me interessa, particularmente. Lá, edificaremos uma nova Alemanha. Ali se acham reunidas todas as condições para uma revolução que permitiria transformar em alguns anos um estado governado e habitado por mestiços corrompidos numa possessão germânica. De resto, nós temos direitos sobre esse continente onde os Fagger, os Welser e outros pioneiros alemães possuem herdades e feitorias. Nosso dever é reconstituir esses velhos patrimônios que uma Alemanha degenerada deixou se dispersarem". Diante da observação do convidado de que a Alemanha teria boas chances de impor seu poder, Hitler afirmou: "Os brasileiros precisam de nós, se quiserem fazer alguma coisa por seu país. O que lhes falta não é tanto capital para frutificar, porém o espírito de empreendimento e talento de organização. Nós daremos ainda uma terceira coisa: nossas ideias políticas. Se há um continente onde a democracia é uma insanidade, esse é a América Latina (...) Trata-se de convencer esses povos de que eles podem sem escrúpulos lançar por terra o seu liberalismo e seu democratismo (...) Eles ainda têm vergonha de ostentar seus bons instintos. Creem-se obrigados a interpretar farsa democrática. Além disso, o Brasil já começa a ter bastante dos Estados Unidos, que não sonham em outra coisa senão em explorar o país". Os trechos principais foram traduzidos para o português. Todo o material faz parte do acervo do Arquivo Público do Estado do Rio de Janeiro. Setor Alemão. Pasta 10. Caixa 0755. Fonte: SANDER, Roberto. O Brasil na mira de Hitler: A história dos afundamentos de navios brasileiros pelos nazistas. Rio de Janeiro: Objetiva, 2007.p. 213 e 215.

${ }^{27}$ A perda de acesso aos mercados financeiros voluntários internacionais de crédito por força moratória, juntamente ao déficit no balanço de pagamentos, levou o Brasil, forçosamente, a uma política de substituição de importações, o que representou um incremento substancial da indústria leve no País. Por outro lado, aumentou a intervenção direta do Estado em ferrovias, navegação e indústrias básicas, como petróleo e aço. Fonte: SKIDMORE, p. 76.
} 
Na Europa, o nazismo crescia. No início de 1939, Lutero Vargas, filho mais velho de Getúlio, apaixonou-se por uma jovem e bela alemã, Ingeborg ten Haeff, durante um jantar em Berlim. Visto com reservas pelo Alto-Comando alemão, o namoro improvável da germânica de sangue ariano com seu amante brasileiro resistiu.

Em $1^{\circ}$ de setembro do mesmo ano, tropas de Hitler invadiram a Polônia. O governo Vargas não demorou a declarar sua neutralidade diante do conflito.

De fato, tal posição assumida pelo Governo Vargas não destoava de seus pares no continente americano. Isso porque, com a irrupção do conflito internacional promovido pelo totalitarismo europeu, reuniram-se, no Panamá, os chanceleres das repúblicas americanas, os quais afirmaram solenemente, em outubro de 1939, a posição de neutralidade geral de seus países ${ }^{28}$.

Contudo, o avanço da situação político-militar da Europa e as ameaças eixistas impuseram, em julho de 1940, uma nova Reunião de Consulta dos Chanceleres, desta vez em Havana. Decorreu desse conclave a deliberação -“de que todo atentado de Estado não-americano contra a integridade ou a inviolabilidade do território, contra a soberania ou independência política de um Estado americano será considerado como ato de agressão contra os estados que firmam esta declaração"--29.

Em maio de 1940, Mussolini, em uma demonstração de simpatia e lealdade para com Getúlio, informou às autoridades brasileiras que a fase mais violenta da guerra estava por começar, e mandou seu filho Bruno buscar Lutero na Alemanha, pilotando um avião militar de seu país, para levá-lo ao Rio de Janeiro. Inge, como era chamada, veio em seguida de navio, casou-se com Lutero e foi morar no Palácio da Guanabara, fato que gerou inúmeras especulações ${ }^{30}$.

Oscilando entre países do Eixo e os Aliados ${ }^{31}$, o regime de Vargas tolerou durante anos as atividades do Partido Nazista no Brasil, que continuou em funcionamento até a entrada do país na guerra ao lado dos Aliados, em 1942.

\footnotetext{
${ }^{28}$ MASCARENHAS DE MORAES, p. 23.

${ }^{29}$ Idem. p. 24.

${ }^{30}$ Ademais, convém acrescentar que a colônia alemã no Brasil era estimada, em 1940, entre 700 e 900 mil pessoas. Havia 937 escolas alemãs no Rio Grande do Sul em 1930, e a população de origem alemã também era grande em Santa Catarina, no Paraná e em São Paulo. A imprensa alemã se propagava. O jornal Deutsche Zeitung atingiu a expressiva tiragem de 55 mil exemplares diários em 1928. Fonte: SEITENFUS, Ricardo. O Brasil vai à guerra- O processo de envolvimento brasileiro na Segunda Guerra Mundial. São Paulo: Manole, 2003. p.11 e 15.

${ }^{31}$ Segundo relato do embaixador norte-americano no Brasil, Jefferson Caffery, ao Secretário do Departamento de Estado americano, a política exterior de Getúlio Vargas consistia em extrair o máximo dos Estados Unidos, de um lado, e o máximo dos poderes fascistas, de outros. Fonte: Jefferson Caffery to Cordell Hull, Rio, 22 abr. 1939, 832.00/1255, RG59. Washington EUA: National Archives.In: MEIRA MATTOS, Carlos de. O General Mascarenhas de Moraes e sua Época. Rio de Janeiro: Biblioteca do Exército Editora, 1983.
} 
Enquanto o regime de Getúlio Vargas flertava com os países do Eixo, o Brasil registrava sua primeira baixa na Segunda Guerra Mundial: José Francisco Fraga, conferente do navio mercante Taubaté.

Fraga morreu quando a embarcação foi atacada por um avião da Luftwaffe próximo à costa do Egisto, em 22 de março de 1941. Segundo relatos do comandante Tinoco, o ataque não cessou mesmo com a bandeira brasileira claramente visível e com o içamento às pressas de uma bandeira branca no mastro principal. Treze tripulantes ficaram feridos.

Em 13 de junho do mesmo ano, outro navio mercante, o Siqueira Campos, foi parado por um submarino alemão próximo ao arquipélago do Cabo Verde. A embarcação só foi liberada depois de ser vistoriada e de ter os documentos fotografados.

Em 14 de agosto de 1941, ainda com os Estados Unidos fora da guerra, o primeiro-ministro britânico Winston Churchil e o presidente americano Franklin Delano Roosevelt emitiram a Carta do Atlântico na chamada Conferência do Atlântico (sob o codinome "Riviera"), a bordo do HSM Prince of Wales ancorado em Argentia, província canadense de Terra Nova ${ }^{32}$.

O documento, com apenas oito diretrizes trazia consigo algumas intenções e a criação de uma visão de mundo após o término da guerra: organizar o caos no qual o nazi fascismo mergulhava a Europa e atrair países aliados para a causa britânica contra Hitler e Mussolini.

Em paralelo, a parceria do Brasil com os Estados Unidos prosperava e produzia frutos. Entre outros incentivos econômicos e comerciais importantes, de se ressaltar a construção da CSN (Companhia Siderúrgica Nacional), em Volta Redonda, financiada pelos americanos com o objetivo de fornecer aço aos Aliados durante a guerra.

No entanto, a Carta do Atlântico não impediu os países do Eixo de atacarem os Estados Unidos em 07 de dezembro de 1941, quando uma esquadra da Marinha Imperial japonesa dizimou a frota americana ancorada na base naval de Pearl Harbor.

Um dia após o ataque japonês à Pearl Harbour, o governo Vargas declarava a solidariedade aos Estados Unidos; por sua vez, no dia 11 de dezembro de 1941, a Alemanha e Itália declararam guerra ao país americano, que logo assumiu uma posição de destaque na guerra.

\footnotetext{
${ }^{32}$ PLESCH, Dan. America, Hitler and the UM-How the Allies won World War II and Forged a Peace. Londres: I. B. Taurus, 2011.
} 
Em $1^{\circ}$ de janeiro daquele ano, foi assinada, em Washington, a Declaração das Nações Unidas, uma aliança militar entre os Estados Unidos, o Reino Unido, a União Soviética e mais 23 países. Os signatários comprometiam-se a empreender todos os esforços possíveis para alcançar a mais pronta derrota do Eixo, ao mesmo tempo em que se obrigavam a não fazer a paz em separado com os inimigos.

Uma reunião ${ }^{33}$ de consultas entre os ministros de todas as Américas foi imediatamente convocada para a tomada de decisão conjunta, no Hemisfério Ocidental, sobre a situação de guerra que agora envolvia a potência norte-americana. O Departamento de Estado queria que todos os países da área rompessem suas relações diplomáticas com as potências do Eixo e, com a exceção do Chile e da Argentina, todos assim agiram.

Nesses auspícios, ao ver seu mais importante parceiro econômico arrastado para dentro do conflito, o Governo do Brasil, em 28 de janeiro de 1942, viu-se pressionado a atender à resolução $\mathrm{n}^{\circ} 15$ da Segunda Reunião ${ }^{34}$ de Consulta dos Chanceleres das Repúblicas Americanas e rompeu relações diplomáticas com os países do Eixo (Alemanha, Itália e Japão).

Sobre esse evento, Aranha afirmou que -“não foi Getúlio, nem fui eu, nem foi ninguém que nos forçou a romper relações. Foi a nossa posição geográfica, a nossa economia, a nossa história, a nossa cultura, enfim, a condição nossa de vida e a necessidade de procurar sobreviver"-- ${ }^{35}$.

Foi o estopim para o início do torpedeamento sistemático de embarcações brasileiras ao redor do mundo, a campanha submarina do eixo ${ }^{36}$, o que resultou em uma dúzia de navios brasileiros atacados em águas nacionais e internacionais por submarinos alemães e italianos, de fevereiro a junho de $1942^{37}$.

\footnotetext{
${ }^{33}$ No período de 15 a 28 de janeiro de 1942, ocorreu a III Conferência de Ministros do Exterior, no Rio de Janeiro.

${ }^{34} \mathrm{Na}$ ocasião, o chanceler brasileiro Oswaldo Aranha, velho amigo e colega de Vargas na Faculdade de Direito de Porto Alegre, alertara o ditador brasileiro, com grande realismo, a respeito da proclamada intenção de neutralidade da Argentina, no sentido de que o Brasil dependia mais dos Estados Unidos (quatro quintos do café exportado, empréstimos) que o país da Bacia do Prata. Fonte: CERVO, Amado Luiz. As relações históricas entre o Brasil e a Itália. Brasília: UNB, 1991. p. 167.

${ }^{35}$ HILTON, Stanley. Oswaldo Aranha- Uma Biografia. Rio de Janeiro: Objetiva, 1994. p. 389.

${ }^{36}$ A convite do Ministério da Marinha, o Almirante Jorgen Horhwer esteve no Brasil e, no dia 28 de março de 1982, na Escola de Guerra Naval, pronunciou uma conferência intitulada "Operações navais da Alemanha". O almirante, que combateu pela marinha alemã na última guerra, não só confirmou como relatou de forma precisa como os submarinos de seu país torpedearam navios brasileiros, no litoral. O depoimento histórico abrange todas as operações navais realizadas nesta parte do oceano Atlântico, do início ao fim das hostilidades, e foi publicado, na íntegra, no número 18 da revista Navigator. Depois da comprovação fornecida pelo arquivo alemão e do depoimento do Almirante Horhwer, querer sustentar que foram submarinos aliados que torpedearam navios brasileiros deixa de ter sentido. Fonte: SILVEIRA, p. 41 e 42.

${ }^{37}$ SANDER, p. 31.
} 
No entanto, entre os dias 16 e 19 de agosto daquele mesmo ano, uma série de ataques empurrou o governo brasileiro de uma vez por todas para dentro do conflito. Em apenas 40 horas, o poderoso submarino alemão U-507 torpedeou seis navios mercantes brasileiros (Baependy, Araraquara, Annibal Benevolo, Itagiba, Arara e Jacyra), causando a morte de centenas de homens, mulheres e crianças ${ }^{38}$.

Tais atentados à soberania brasileira, aliado às manifestações populares de repúdio aos ataques, dirigidas especialmente contra imigrantes alemães, japoneses e italianos, conduziram Getúlio a declarar guerra ao Eixo dias depois ${ }^{39}$, baixando o decreto n. 10.358 , de 31 de agosto de 1942 .

O Brasil, então, se colocava de modo claro e definitivo ao lado dos Aliados, o que não deixava de ser uma grande contradição. O Brasil de estrutura ditatorial, que ainda mantinha encarcerados aqueles que contestavam seu regime; o Brasil da censura, sem representação parlamentar; o Brasil, enfim, com as liberdades cerceadas entrava na guerra pela democracia contra o Eixo totalitário.

No mês posterior ao rompimento das relações com o Eixo, foram assinados importantes acordos comerciais ${ }^{40}$ com os EUA envolvendo material bélico, ferro e borracha $^{41}$.

Naquele momento, o Exército do Brasil tinha um contingente de aproximadamente 66 mil soldados, organizados em 05 divisões de infantaria, das quais 03 foram transferidas para o nordeste, sob o comando do general Leitão de Carvalho. O restante da tropa ficaria, como de hábito, na fronteira do País com a Argentina, então percebida como principal inimigo externo potencial do Brasil ${ }^{42}$.

O empenho por parte do presidente Roosevelt em estreitar relações com o Brasil tinha uma motivação clara: com diversos países da Europa já ocupados pelo Eixo, a importância estratégica do litoral brasileiro crescia aos olhos dos Aliados. Para os Estados

\footnotetext{
${ }^{38}$ Carlos Eduardo Franco Azevedo, Gláucio Érico de Almeida Silva, Eros José Sanches (organizadores). $5^{\mathbf{0}}$ Batalhão de engenharia de combate blindado: 100 anos de história - Tomo II - União da Vitória (PR): UNIUV, 2015. p. 196 e 197.

${ }^{39}$ Só restou ao Governo Brasileiro a declaração de guerra, efetivada no dia 22 de agosto de 1942: "O Senhor Presidente da República reuniu hoje seu ministério, tendo comparecido todos os ministros. Diante da comprovação dos atos de guerra contra a nossa soberania, foi reconhecida a situação de beligerância entre o Brasil e as nações agressoras". Fonte: SILVEIRA, p. 43

${ }^{40}$ Em 03 de março de 1942, os Estados Unidos firmaram com o Brasil um acordo Lend-Lease (empréstimoarrendamento), o qual contemplava o fornecimento de armas e munições de guerra no expressivo valor, para a época, de 360 milhões de dólares, integralmente pagos pelo Brasil em parcelas, a última delas liquidada em $1^{\circ}$ de julho de 1954. Veja, nesse sentido, o texto "Causas e consequências da participação do Brasil na II Grande Guerra", publicado pelo Departamento de Imprensa Nacional, em 1958, no Rio de Janeiro.

${ }^{41}$ No caso da borracha, o acordo previa o fornecimento de toda a produção nacional para a exportação por um período de cinco anos.

${ }^{42}$ CAMPBELL, Keith. Brazil in the Second World War. Pretoria, South Africa: Unisa Centre for Latin American Studies, 1992. p.5.
} 
Unidos, era inconcebível ter um país de dimensões continentais na América do Sul dominado pelos nazistas. Por essa razão, enquanto se alinhavam acordos econômicos ${ }^{43}$, o embaixador americano Jefferson Caffery endereçou uma carta a Getúlio Vargas solicitando, em nome de Roosevelt, permissão para a instalação de bases militares na costa brasileira.

A mais importante delas estava situada bem perto do saliente do Nordeste, ao lado da cidade de Natal, no campo denominado Parnamirim, que ficou conhecido também como “Trampolim para a Vitória”. Localizada no ponto mais próximo entre os continentes sul-americano e africano, a base aérea de Parnamirim teve papel fundamental na batalha de El Alamein, no norte da África, uma vez que as rotas para Dakar estavam bloqueadas pelas tropas nazistas na Europa.

Essa base tornou-se responsável por um triângulo que defrontava o teatro de operações meridional, compreendendo o sul da Europa, o norte da África, o Caribe e a costa brasileira, sendo, por algum tempo, a mais movimentada base norte-americana fora das fronteiras dos Estados Unidos ${ }^{44}$.

A esse respeito, afirma $\mathrm{McCann}^{45}$ :

"[...]a base aérea de Parnamirim (Natal, RN) foi o ponto focal do sistema de transporte aéreo que se estendeu para o norte, através de Belém e Guiana até Miami e para o leste via Ilha de Ascensão e a África até o teatro-de-operações China-Burma-Índia. Foi orgulhosa e corretamente chamada de trampolim para a vitória, já que, sem ela, os problemas de suprimento em 1941 e 1942 teriam sido insuplantáveis".

Porém, Getúlio Vargas não estava contente. Em dezembro de 1942, percebendo que -“em tempos normais de paz, o Brasil não teria uma margem de negociação privilegiada" 46 e, visando vantagens em um pós-guerra favorável aos Aliados, almejava que a participação do país no conflito não se limitasse a atos formais e a cessão de bases, o fornecimento de materiais estratégicos, ou "contingentes simbólicos".

\footnotetext{
${ }^{43}$ No dia 23 de maio de 1942 foi assinado em Washington o acordo que criou a Comissão Mista de Defesa BrasilEstados Unidos (Joint Brazil/United States Defense Comission), no qual foram estabelecidas normas e condições necessárias para regular o uso de força militar, auxílio econômico e fornecimento de matéria-prima. Dispunha, também que o Brasil operaria bases aeronavais no Nordeste e estas poderiam ser utilizadas por forças militares norte-americanas, da forma como seria definido posteriormente. Fonte: SILVEIRA, p. 42.

${ }^{44}$ A história oficial do Exército norte-americano atesta que -"em maio de 1943 a base aérea de Natal estava lidando com mais movimentações de aviões por dia do que lidara por mês um ano antes. A rota área para o Brasil, planejada para a defesa hemisférica, tornou-se em 1943 o funil aéreo para os campos de batalha do mundo"--. CONN, Fairchild. The Framework of Hemisphere Defense, p. 326.

${ }_{45}$ McCANN JR. Aliança Brasil-Estados Unidos, 1937/1945, p.194.

${ }^{46}$ NETO, Lira. Getúlio 1930-1945: Do governo provisório à ditadura do Estado Novo. São Paulo: Companhia das Letras, 2013.
} 
Desejava que o país modernizasse as forças armadas nacionais e executasse ações militares fora do continente americano ${ }^{47}$, no que contava com o apoio do Exército e do Ministério das Relações Exteriores ${ }^{48}$, formando consenso interno. O envio de um grande contingente representaria, ainda, a experiência necessária para garantir a soberania contra os inimigos regionais reais ou imaginários, principal pleito dos militares.

Ademais, pensavam as lideranças políticas e militares nacionais que, com seus soldados lutando na Europa, o Brasil estaria pronto para tomar parte no "concerto das Grandes Nações"49.

Sua intenção tomou corpo quando Roosevelt o visitou em Natal, em 28 de janeiro de 1943, poucos meses depois de vencida a batalha de El Alamein.

A Conferência entre Roosevelt e Getúlio Vargas, ocorrida como apêndice da Conferência de Casablanca ${ }^{50}$, é geralmente aceita como o momento em que o presidente norte-americano passa a apoiar a iniciativa de participação direta do Brasil na guerra ${ }^{51}$, e teve, de fato, a intenção de tratar de questões estratégicas relacionadas à cooperação militar de uma campanha conjunta.

Roosevelt, mantendo-se fiel à sua política de boa vizinhança, aceitou apoiar a ação, a despeito da posição contrária dos líderes militares norte-americanos ${ }^{52} \mathrm{e}$, o projeto da FEB andou a partir deste momento. Tratava-se da criação de um instrumento militar nacional destinado a desagravar a ofensa e a cooperar com as Nações Unidas na missão de destruir o inimigo comum.

Na ocasião, o Brasil aderiu à Carta do Atlântico ${ }^{53}$, acertando-se igualmente a participação de tropas brasileiras ${ }^{54}$ no teatro de guerra europeu. Foi, então, criada a FEB,

\footnotetext{
${ }^{47}$ Getúlio, ainda que estivesse envolvido na guerra, certamente não considerava a derrota do Eixo a mais importante meta de sua política exterior. Isso era objetivo e obrigação das grandes potências. A aliança com os Estados Unidos devia dar frutos imediatos no sentido da modernização e industrialização do Brasil. Fonte: ALVES, Vágner Camilo. Da Itália à Coréia: decisões sobre ir ou não à guerra. Belo Horizonte: Editora UFMG; Rio de Janeiro: IUPERJ, 2007. p. 80.

${ }^{48}$ O MRE apoiava porque acreditava que tal medida cimentaria a aliança especial com os Estados Unidos e daria maior acesso, para o país, às decisões internacionais do pós-guerra. Já o Exército, porque queria, imediatamente, um volume maior de auxílio militar. Fonte: Idem. P; 124 e 125.

${ }^{49}$ MAXIMIANO, César Campiani. Barbudos, sujos e fatigados: soldados brasileiros na Segunda Guerra Mundial. São Paulo: Grua, 2010. p. 37.

${ }^{50}$ Conferência de Casablanca foi realizada entre 14 e 23 de janeiro de 1943, no Marrocos, na qual o presidente dos Estados Unidos se reuniu com o Primeiro Ministro Britânico para deliberar sobre a estratégia comum de guerra dos dois países. Os resultados dessa Conferência, aliás, têm muita relação com a pauta discutida em Natal, caminho de retorno de Roosevelt para casa. A despeito de algumas discordâncias entre britânicos e norte-americanos, de Casablanca saiu a decisão formal de que a guerra somente acabaria com a rendição incondicional das potências do Eixo. Esta declaração visava fortalecer o apoio doméstico à guerra nos dois respectivos países, e também dar garantias de aliança aos russos, que enfrentavam o grosso do esforço de guerra alemão em seu próprio território e mostravam aberta insatisfação com o desequilíbrio na "divisão de esforços" entre os Aliados. Fonte: ALVES, p. 77 e 78.

${ }^{51}$ CONN, p. 328.

52 ALVES, p. 125.

53 ALMEIDA, Paulo Roberto. Relações Internacionais e Política Externa do Brasil. Porto Alegre: Editora da Universidade Federal do Rio Grande do Sul. 1998. p. 122-ss.
} 
Força Expedicionária Brasileira, fruto da resolução no 16 da Comissão Mista de Defesa Brasil-EUA e da portaria MG no 47/44, na data de 09 de agosto de 1943, a respeito da qual se tece maiores comentários a seguir.

No folclore da época corria uma anedota: preocupado com a escolha do comandante e com o embarque da força expedicionária, o Presidente Vargas teria confidenciado esse estado de espírito a um velho chefe militar. O confidente ficou mudou e meditativo. Instado pelo Presidente Vargas sobre o motivo do silêncio, respondera: "Não estou pensando na ida da FEB, e sim na sua volta" ${ }^{\text {"55. }}$.

Assim, em 07 de outubro de 1943, o general de divisão João Batista Mascarenhas de Moraes, tido como -“homem tranquilo, cuja falta de ambição política agradava a Getúlio"-foi nomeado comandante da FEB. Sob as ordens do general Mascarenhas de Moraes, estavam o general Euclides Zenóbio da Costa, comandante da infantaria, o general Cordeiro de Farias, comandante da artilharia, e o general Olympio Falconière da Cunha, responsável pelos elementos não divisionários. $\mathrm{O}$ chefe da inteligência era o tenente-coronel Amaury Kruel, e o responsável pelas operações de guerra foi o tenente-coronel Humberto Castello Branco. ${ }^{56}$

\section{(iii) A formação da Força Expedicionária Brasileira.}

Para melhor situar a FEB no contexto da história do Exército, é conveniente que se relembre os primórdios do Exército brasileiro, do tempo do Brasil-Colònia, sua constituição, evolução até a época do episódio FEB e concluir com fatos ocorridos posteriormente.

No tempo do Brasil-Colônia, o Exército era um prolongamento do exército da metrópole e, portanto, recebia através deste a influência das várias escolas militares europeias mais desenvolvidas, refletida em regulamentos e no comportamento da tropa estacionada no Brasil.

Após a Independência, o Exército Imperial começou a tomar forma própria dentro de regulamentos coloniais anteriores. Começaram a surgir as lideranças militares verdadeiramente brasileiras, tais como Caxias e Osório. Por ocasião da guerra da Tríplice

\footnotetext{
${ }^{54}$ Segundo Boris Fausto -“(...) a decisão de enviar os contingentes- exemplo único entre os países latino-americanosresultou de fatores combinados, entre eles o interesse do governo Vargas em reforçar seu prestígio, considerando-se o entusiasmo da opinião pública pela iniciativa, bem como o desejo de ter uma posição importante nas negociações do pós-guerra, especialmente no âmbito da Organização das Nações Unidas (ONU), de cuja organização as grandes potências já cogitavam"--. Fonte: FAUSTO, p. 105.

${ }^{55}$ COSTA, Octavio. Trinta anos Depois da Volta. Rio de Janeiro, Biblioteca do Exército Editora, 1976, p. 83.
} 
Aliança, ou Guerra do Paraguai, essas lideranças cresceram, não só no Exército como também na Marinha Imperial.

Cessado o conflito com o Paraguai, apesar de a tropa imperial sair vitoriosa, iniciou-se um período de decadência das Forças Armadas. Os militares se viram diante de antagonismos políticos, alguns inexplicáveis, expressos nas chamadas "questões militares" $" 57$.

Proclamada a República, seus dois primeiros presidentes foram militares de carreira. Mas, apesar da marcante atuação do Exército no movimento republicano, seu papel foi em realidade de segundo plano.

No primeiro ano do século XX, um grupo de oficiais iniciou um movimento nativista na tentativa de melhorar a condição técnica e operacional do Exército. Refletia-se aí o profissionalismo militar europeu, principalmente o alemão, observado por esses oficiais reformistas.

Este movimento revelava, supostamente, o início de uma forte influência alemã no Exército. Tudo se encaminhava para que o Brasil recebesse sua primeira missão militar, que seria, evidentemente, alemã. Com a eclosão da I Guerra Mundial, esse movimento ficou anulado.

Sobreveio o fim do conflito, e com a vitória aliada, não havia mais condições técnicas, nem políticas, para a vinda de uma missão militar alemã. Pelo contrário, os tratados diplomáticos encaminharam-se na direção da França, razão pela qual, ainda na década de 20, o país acolheu a Missão Militar Francesa.

Essa missão, voltada principalmente para oficiais de patentes de major para baixo, na tentativa de preparar futuros comandantes, tinha como primeira diretriz o desenvolvimento e reformulação dos órgãos de ensino militar, dentro dos conceitos da doutrina francesa, exercendo também influência no serviço cartográfico e, evidentemente, no investimento, na França, de material militar do qual o Exército Brasileiro estava carente.

Assim, no início da década de 20 a Missão Francesa tinha influenciado a doutrina e a organização das Forças Armadas. À época, o prestígio do exército francês tinha atingido o auge por força de suas vitórias na Primeira Guerra Mundial, o que levou os países periféricos a buscarem inspiração em suas doutrinas militares.

\footnotetext{
${ }^{56}$ BOURNE, V. Richard. Getúlio Vargas- A Esfinge dos Pampas. São Paulo: Geração Editorial, 2012. p. 161.

${ }^{57}$ SILVEIRA, p. 260.
} 
Quando do ingresso do Brasil na Segunda Guerra Mundial, não foi pequeno o impacto das transformações necessárias no sentido de adaptar as suas Forças Armadas às exigências do novo conflito, uma vez que os comandantes brasileiros tiveram de se adequar a diretrizes distintas daquelas que haviam orientado a sua atuação até então.

O Exército possuía um efetivo de 60 mil homens concentrados no Rio Grande do Sul, Rio de Janeiro e São Paulo. Sua instrução, desde 1920, obedecia a padrões da Missão Militar Francesa. O armamento era a base do adquirido pela organização de 1908, liderada pelo Marechal Hermes da Fonseca. Constituía-se de fuzis Mauser 1908, metralhadoras Madsen e canhões Krupp 75. Predominava o transporte e a tração à base do cavalo e do muar ${ }^{58}$.

As Forças Armadas brasileiras precisaram abandonar princípios organizacionais aprendidos com os franceses e adotar, com urgência, ensinamentos capazes de proporcionar condições de enfrentar o exército alemão na Itália. Porém, tal tarefa não era fácil, considerando-se que a década de 30 havia sido especialmente desfavorável às Forças Armadas, em razão da crise econômica, que contribuiu para o sucateamento do equipamento militar.

A tendência inicial do Exército brasileiro foi a de se aproximar da Alemanha nazista, processo facilitado pelo incremento das relações comerciais entre aquele país e o Brasil no final da década de 30. Parecia a muitos que o futuro pertencia aos países fascistas e que o tempo das democracias liberais havia, em definitivo, ficado para trás, como Vargas profetizaria- erroneamente- no dia 11 de junho de 1940, em discurso a bordo do Minas Gerais. ${ }^{59}$

Contudo, poucos anos depois, não somente o Brasil autoritário romperia politicamente com a Alemanha, aliando-se aos seus adversários democráticos, como as democracias liberais iriam derrotá-la completamente no campo de batalha.

A simpatia de militares e determinados políticos civis em relação aos países fascistas europeus, porém, não contaminou todo o governo brasileiro, pois certos setores governamentais mantinham-se firmes no entendimento de que o Brasil deveria se alinhar aos Estados Unidos e não à Alemanha nazista.

Em 31 de agosto de 1942 o Brasil decretou o estado de guerra, por intermédio do Decreto presidencial de $\mathrm{n}^{\mathbf{o}}$ 10.358. Ainda assim, o Estado brasileiro retardou,

\footnotetext{
${ }^{58}$ BENTO, Claudio Moreira (Org.) et GIORGIS, Luiz Ernani Caminha. Brasil- Lutas contra invasões, ameaças e pressões externas (Em defesa de sua Integridade, Soberania, Unidade, Independência e Integração; e da Liberdade e Democracias Mundiais). Resende-RJ: FAHIMTB/IHTRGS, 2014. p. 396.

${ }^{59}$ Idem. p. 691 e 692.
} 
sobremaneira, o envio de suas tropas ao teatro de operações italiano em decorrência das dificuldades de organizar, armar e treinar adequadamente uma divisão de combate.

A declaração de guerra contra o Eixo tornou-se inevitável, considerando-se os ataques efetuados por submarinos alemães aos navios mercantes brasileiros no hemisfério Norte e, posteriormente, no próprio litoral nacional, atitude agressiva que desencadeou

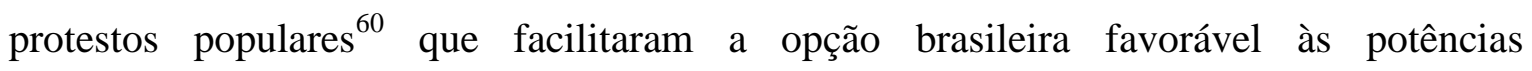
$\operatorname{antinazistas}^{61}$.

Para que se possa fazer uma ideia da agressão, foram mais de 31 navios atingidos pela ação dos submarinos alemães até 23 de outubro de 1943, com perdas de 971 pessoas, sendo 469 tripulantes e 502 passageiros ${ }^{62}$.

A gravidade de tais ataques e do bloqueio do litoral brasileiro foi de tamanha monta que, em 1942, o governo brasileiro chegou a cogitar a interrupção da navegação de cabotagem, o que, se ocorresse, causaria a asfixia da economia nacional ${ }^{63}$.

Por outro lado, também não se pode esquecer de forma alguma que, à época, já estava suficientemente claro quem venceria a guerra, embora não se soubesse exatamente quando isto ocorreria ${ }^{64}$. A clara desproporção de forças e de recursos humanos e materiais entre os Aliados e o Eixo, sobretudo após a entrada dos Estados Unidos na guerra, tornou-se evidente para o governo, o que fez o oficialato germanófilo, perder influência em detrimento de políticos favoráveis aos americanos, a exemplo de Oswaldo Aranha.

É preciso registrar, ainda, que o alinhamento aos Estados Unidos poderia trazer, aos olhos de Vargas ${ }^{65}$, (como trouxe) inegáveis vantagens ${ }^{66}$ ao Brasil, ao passo que a adesão ao Eixo ou a neutralidade diante do conflito mundial em nada beneficiaria o Estado sul-americano.

Assim, o Brasil permitiu que os americanos construíssem bases aéreas no Norte-Nordeste do país- a de Natal era a maior delas-, cedendo aos norte-americanos, por

\footnotetext{
${ }^{60}$ Getúlio reconheceria isso, quando em discurso de 7 de setembro de 1942, lembrou: "Protestastes com indignação, solicitastes por todas as formas de expressar a vontade popular que o governo declarasse guerra aos agressores, e assim foi feito", VIGEVANI. Questão nacional e política exterior. Um estudo de caso: formulação da política internacional do Brasil e motivações da Força Expedicionária Brasileira. p. 244,245 e 353.

${ }^{61}$ Werneck Sodré, por exemplo, escreveu que - “diante da pressão popular, foi inevitável encarar o problema da participação de forças militares brasileiras no teatro de guerra europeu”--. SODRÉ, p. 286.

62 SANDER, p. 146.

${ }^{63}$ BONALUME, Ricardo Neto. A nossa Segunda Guerra. Rio de Janeiro: Expressão e Cultura, 1995. p. 119.

${ }^{64}$ ALVES, p. 86.

${ }^{65}$ Vargas, presidente e ditador, líder máximo do Estado Novo, era, sem a menor dúvida, o decisor mais importante. Sua primazia é, por sinal, aceita pela maior parte da literatura especializada: ver McCANN JR, p. 242; e VIGEVANI, p. $213 / 214$.

66 Stanley Hilton aponta como razão quase que exclusiva para a criação da FEB o desejo de manter ou mesmo incrementar o fluxo de armas dos Estados Unidos para o Brasil, transferido por meio do Lend-Lease. HILTON, p. 409.
} 
10 anos, o uso de 10 aeroportos estratégicos naquela localidade ${ }^{67}$, além de cooperação nas operações antissubmarinas.

Nessa senda, Estados Unidos e Brasil concordaram com o envio de uma força militar $^{68}$ para integrar as tropas aliadas que avançavam lentamente na frente italiana, "o último ganho de grande porte do aliado especial”, a qual, muito embora fosse secundária, nem por isso era completamente destituída de efetiva importância.

A FEB, em verdade, tinha dupla finalidade no que tangia ao Estado brasileiro. Do ponto de vista militar, era uma forma de aparelhar e modernizar o Exército através do auxílio norte-americano. Em termos diplomáticos, a FEB devia selar a aliança BrasilEUA, levando o Brasil a uma posição internacional muito mais importante no pós-guerra, parte atuante nas futuras conferências de paz e no processo de reordenamento internacional como aliado incontestável dos Estados Unidos. ${ }^{69}$

Contudo, o significado e a importância do engajamento das Forças Armadas continuam a ser objeto de intensos debates ${ }^{70}$. É claro que a presença aliada no norte da Itália, menos importante das três áreas de atuação aliada ${ }^{71}$, serviu para impedir que o avanço de segmentos do Exército alemão. Mas, ainda que se admita que a guerra na Itália contribuiu para a derrota da Alemanha, não se pode deixar de notar que a diminuta força enviada revelou-se secundária, ainda mais em se tratando de um teatro de operações relativamente desimportante, como foi o italiano.

Neste aspecto, tem razão Ricardo Bonalume Neto quando afirma que, para os aliados -“a guerra na Itália aconteceu por falta de coisa melhor ${ }^{72,--. ~ E s t a ~ ' c o i s a ~ m e l h o r ', ~}$ como a história veio a demonstrar tardiamente, veio a ser a invasão à Normandia, que demoraria a ser concretizada.

No entanto, é preciso levar em conta dois aspectos muito importantes. Quando o Brasil entrou na guerra, a vitória ainda estava longe de ser uma certeza para os aliados, e

\footnotetext{
${ }^{67}$ ALVES, p. 86.

${ }^{68}$ Idem. p 106 e 107.

${ }^{69}$ MOURA. Sucessos e ilusões- relações internacionais do Brasil durante e após a Segunda Guerra Mundial, p. 38.

${ }^{70}$ A esse respeito, recorda-nos Cesar Campiani Maximiano que --" "a grandiloquência e ufanismo das versões oficiais tornaram necessários trabalhos críticos em razão inversamente proporcional às respostas dadas aos esforços de difamar o desempenho brasileiro na Itália: foi preciso igualmente que os pesquisadores reduzissem sua produção a níveis constrangedores de explicações básicas sobre a inserção da tropa da FEB em uma coalizão multinacional e sobre os limites de atuação de uma única divisão de infantaria que, sozinha, jamais poderia ter feito mais do que lhe cabia"--. MAXIMIANI, p. 32. De outro lado, Francisco Ferraz, afirma que a visão segundo a qual a participação da FEB foi insignificante na guerra demonstra um desconhecimento de um dos princípios básicos da história militar contemporânea, pois todas as frentes são interligada e os soldados que estão em uma frente "secundária" são tão importantes quanto aqueles que estão nos combates cruciais. Fonte: A participação brasileira na Segunda Guerra Mundial e a reintegração social dos veteranos de guerra da Força Expedicionária Brasileira: Notas de Pesquisa. Júlia Amabile Aparecida de Souza Pinta e Francisco César Alves Ferraz.

${ }^{71}$ ALVES, p. 86.

${ }^{72}$ BONALUME, p. 136.
} 
quando iniciou a formação de sua força expedicionária, em 1943, era uma nação essencialmente agrícola, quase sem indústrias, com uma população em torno de 50 milhões de habitantes ${ }^{73}$.

Contudo, a importância da participação brasileira na Segunda Guerra Mundial é outra, pois fez com que o Brasil se posicionasse, a partir de então, ao lado dos Estados Unidos durante toda a Guerra Fria; ademais, contribuiu para despertar a consciência dos brasileiros no tocante à natureza autoritária do Estado Novo e, finalmente, expressou o compromisso do Brasil com a derrota das forças nazifascistas.

Com um efetivo de 25.334 homens, a FEB participou ativamente das operações de guerra no Teatro do Mediterrâneo de julho de 1944 a maio de 1945, na Campanha da Itália, atuando à luz de uma inevitável influência dos ensinamentos doutrinários americanos. Recorda a esse respeito um importante pesquisador da FEB, -"para os milhares de brasileiros incorporados ao Exército Americano, essa interação trouxe mudanças profundas em termos de treinamento, alimentação, fardamento, equipamento, armamento e relações disciplinares. Pela primeira vez, os soldados brasileiros recebiam exatamente a mesma ração e uniformes que seus superiores ${ }^{74, "-.}$

Naturalmente, pode-se imaginar o impacto que tais mudanças acontecidas no Exército tiveram entre soldados acostumados ao 'mandonismo' que impregnava as relações sociais no Brasil, inclusive nas Forças Armadas ${ }^{75}$. É possível conceber que tais militares não saíram ilesos de tal experiência, passando a experimentar a sensação de que o Brasil era, no fundo, um país iníquo e pouco democrático, no qual predominavam formas acentuadamente hierarquizadas de interação social.

Quanto à composição da FEB, não se deve furtar ao esclarecimento de que sua mobilização ${ }^{76}$, instituída através do decreto $n^{\circ} 10.451$, de 16 de setembro de 1942, foi

\footnotetext{
${ }^{73}$ SILVEIRA, p. 17.

${ }^{74}$ MAXIMIANO, p. 28.

${ }^{75} \mathrm{Na}$ FEB houve uma grande quantidade de soldados convocados, ou seja, civis e entre os oficiais de baixa patente, especialmente tenentes, também havia um número significativo de homens que não tinham nas Forças Armadas sua profissão. Como foi percebido por Cesar Maximiano, no caso da FEB os tenentes eram os oficiais que os praças e graduados mais tinham contato, razão pela qual ocorreu uma flexibilização na convivência entre civis e militares de carreira de forma mais fácil.

${ }^{76}$ A mobilização dos efetivos da FEB esbarrou em problemas de difícil solução, alguns dos quais acabaram se tornando ensinamentos para reformas no sistema de mobilização após a Segunda Guerra Mundial. Resumidamente foram eles: (i) Reserva desprovida de pessoal especializado para fazer face aos novos armamentos e equipamentos de transporte, guerra química, comunicações, engenharia, etc; (ii) Alta percentagem de incapazes para o serviço (em especial problemas dentários e psicológicos), levando ao abrandamento dos critérios de seleção e a consequências indesejáveis; (iii) a seleção intelectual deixou a desejar em diversos aspectos, com centenas de analfabetos tendo sido incorporados não atendendo às necessidades de pessoal para lidar com equipamentos sofisticados, o que exigia um nível intelectual mais elevado; (iv) rodízios e substituições excessivos dos elementos incorporados, sobrecarregando a administração e retardando a instrução; (v) interesses pessoais em jogo (fundo afetivo e emotivo) e; (vi) falta de preparação psicológica do país para a guerra, cujo povo não chegou a compreender bem as causas que levaram seus filhos a participarem de
} 
tarefa complexa. A sociedade de massas criou a guerra feita não mais por milhares de soldados profissionais, mas por toda a população, recrutada seja para o combate, seja para produzir armas ou alimentos em escala gigantesca. Foi um dos raros momentos em que o conceito de "nação em armas" deixou de ser ideologia e virou realidade ${ }^{77}$.

De fato, nem todos os soldados que participaram da guerra estavam ligados Exército Brasileiro, sendo necessária a convocação de civis, policiais de São Paulo ${ }^{78}$ e expressivo número de oficiais da reserva ${ }^{79}$ formados pelo CPOR e NPOR, para integrarem a FEB e serem transformados em soldados, armeiros, enfermeiras, médicos e oficiais militares $^{80}$.

Para tal, foram constituídas Juntas Médicas de Seleção, em 1943, às quais caberia a seleção dos efetivos sob o ponto de vista médico. A rigorosa seleção médica dos efetivos destinados às tropas combatentes foi um dos pontos marcantes na mobilização do Exército na $2^{\mathrm{a}}$ Guerra Mundial, com rígidos índices que levaram a um alto número de incapacitados ${ }^{81}$-- fato que também foi visto em outros países, incluindo os Estados Unidos $^{82}$.

A expectativa inicial era a seleção de cerca de 60.000 a 100.000 homens para integrarem a FEB, num espaço de tempo de três meses, cujo perfil desejável seguia índices e coeficientes norte-americanos, consoante determinação do General Souza Ferreira, então Diretor de Saúde, e residia na busca pelo vigor físico, equilíbrio emocional e mental, além de um mínimo de desenvolvimento intelectual com certa maturidade. ${ }^{83}$

Para ser escolhido para a FEB, no princípio dos processos de seleção médica, era obrigatório que o indivíduo fosse classificado como "Classe Especial". Isso implicava um grande aumento do padrão de saúde necessário para que um homem fosse enviado à Europa, superior àquele exigido para o Exército. Assim, um homem podia ser apto para o Exército e inapto para a $\mathrm{FEB}^{84}$.

\footnotetext{
uma campanha externa. Fonte: http://www.aman.ensino.eb.br/histgeo/AFEBna2GM/capitulo_3APrepdaFEB.htm (acesso em 23.08.2002).

${ }^{77}$ BONALUME, p. 7.

${ }^{78}$ TElHADA, Paulo Adriano L.L. A Polícia de São Paulo nos Campos da Itália. KMK Gráfica e Editora Ltda. 2001. 632 páginas.

${ }^{79}$ Esses jovens tinham completado o serviço militar nos Tiros de Guerra, recebendo instrução militar mais sumária em meio período, o que permitia um aproveitamento das horas vagas para estudo ou trabalho nas profissões civis. Fonte: MAXIMIANO, p.54.

${ }^{80}$ BENTO, Claudio Moreira (Org.), p. 411.

${ }^{81}$ http://www.aman.ensino.eb.br/histgeo/MedMil/SelMedFEB.htm (A Seleção Médica para a Força Expedicionária Brasileira) (acesso em 23.08.2002).

${ }^{82}$ Editorial da revista "The Nation", de 22 de julho de 1944, sob o título "The Health Scandal".

83 http://www.aman.ensino.eb.br/histgeo/MedMil/SelMedFEB.htm (A Seleção Médica para a Força Expedicionária Brasileira) (acesso em 23.08.2002).

${ }^{84}$ MAXIMIANO, p.55.
} 
Com o andamento dos trabalhos e as análises dos resultados obtidos, verificou-se a necessidade de serem introduzidas algumas alterações, sobretudo nos índices e critérios observados.

Afinal, conforme McCann $\mathrm{Jr}^{85}$, os exame realizados em todo o território nacional:

“(...) proporcionaram um quadro depressivo da situação da saúde no Brasil: subnutrição generalizada, desenvolvimento físico precário, tuberculose, saúde dentária pobre, sífilis e lesões correlatas, disfunções do sistema cardiovascular e a prevalência de problemas viróticos, como o tracoma. Os exames expuseram também um dos mais tristes aspectos do subdesenvolvimento- saúde pobre e pobre assistência de saúde. Podiam também ter convencido o estado-maior geral da temeridade de uma extensa mobilização(...)."

Em 1949, um grupo variado de oficiais da reserva produziria um polêmico livro com sérias críticas ao Exército e à FEB. Em 'Depoimentos de Oficiais da Reserva' o então tenente José Alfio Piason declara:

“(...) Estudado e organizado um exame contencioso e completo nos moldes do executado no Exército Americano, médicos civis foram chamados a colaborar, em grande número, e a máquina começou a funcionar. A percentagem dos julgados incapazes foi inicialmente, enorme; mas, contornou-se o resultado, aconselhando-se exames mais brandos, ou seja, não levando em conta certos pequenos detalhes, como, por exemplo, o estado dos dentes, tanto que "dezenas de militares brasileiros (centenas ou milhares, diríamos nós), inclusive vários oficiais, apresentaram-se com os dentes em precária situação e em condições, portanto, de lhes ameaçar o equilíbrio físico", logo após a chegada do $1^{\circ}$ Escalão à Itália, como se lê às páginas 45 e 46 do livro "A FEB pelo seu comandante" do Marechal J.B. Mascarenhas de Moraes. (...) Praticamente todos os soldados examinados foram julgados capazes, Classe E (perfeita integridade física e psíquica!)."

\section{O $1^{\mathrm{o}}$ Tenente R2 de Infantaria, Clovis Garcia ${ }^{87}$, que seguiu no $1^{\mathrm{o}}$ Escalão da}

FEB, com o $6^{\circ}$ R.I., como comandante de pelotão de metralhadoras, fez uma denúncia ainda mais grave, ao relatar este episódio:

“(...) como as condições requeridas nesses exames dessem uma percentagem pequena de homens considerados aptos para a guerra- alguns médicos da comissão examinadora afirmaram-nos extra-oficialmente, naquela ocasião, que $80 \%$ dos efetivos examinados do Regimento tinham sido julgados incapazes- as autoridades militares adotaram um critério surpreendente e cômodo para completar os efetivos da $1^{\text {a }}$ Divisão Expedicionária, pelo menos em nosso Regimento. Ao invés de convocar novos elementos e continuar as inspeções médicas até conseguir o número desejado de soldados aptos (e não seria crível

\footnotetext{
${ }^{85}$ Mc CANN JR, p. 291 e 292.

${ }^{86}$ Itálicos e aspas do autor. O tenente Piason serviu como Oficial de Informações (S-2) do I/6 ${ }^{\circ}$ RI. PIASON, José A. "Alguns erros fundamentais observados na FEB". In: ARRUBA, Demócrito C. de. (Org.) Depoimento de oficiais da reserva sobre a FEB. São Paulo: Ipê, 1949, p. 78 e 79.

${ }^{87}$ Clovis Garcia. Depoimentos de Oficiais da Reserva sobre a FEB. São Paulo: IPÊ, 1950. p.290.
} 
que numa população de 45 milhões não se conseguisse 25 mil homens normais, ou seja, $0,0002 \%$ da população), a decisão tomada foi a de rever as fichas dos exames já feitos. Foram dispensados os médicos civis e, reorganizadas as juntas, agora só com os médicos militares, estes receberam ordem de efetuar a revisão, mas no papel, sem novo exame dos candidatos. Atenuando o rigor das inspeções e revendo os laudos médicos sem um critério objetivo, essa decisão das autoridades só poderia dar um resultado. Começamos a receber soldados em péssimas condições, atestando a precariedade da inspeção médica. Basta notar, por enquanto, que no meu pelotão, quando embarcamos, havia soldados sem nenhum dente na boca, um que sofria do coração além de gago e, finalmente, ainda outro sujeito a ataques de origem epiléptica e que muito trabalho deu, posteriormente, na Itália".

No relatório apresentado pelo então General de Divisão, comandante da FEB, Mascarenhas de Moraes ${ }^{88}$, ao Ministro da Guerra, fazendo um balanço das ações do Brasil no Teatro de Operações da Itália, podemos observar a dificuldade em compor os quadros da unidade expedicionária:

"Estabelecidas as condições mínimas a satisfazer para integrar a FEB, as diversas Juntas de Inspeção (...) começaram o seu penoso trabalho, constatandose desde logo as maiores decepções, pela massa de homens, oficiais e praças, que nem sequer se classificaram na categoria "Normais".

No $11^{\circ}$ RI (S. João d'El Rey) apenas três homens: um capitão, um sargento e um soldado conseguiram a classificação "Especial", isto é, a única que permitiria integrar a FEB. O mesmo descalabro se assinalava em todas as outras unidades. Tão calamitosa se apresentou a situação que a Diretoria de Saúde recebeu instruções para admitir, também, os homens da categoria "Normal".

As medidas para o complemento dos efetivos em face dos aspectos verdadeiramente alarmantes da Seleção Física, foram drásticas, estendendo-se a todas as Regiões Militares, com resultados compensadores, principalmente pelos elementos oriundos das $3^{\mathrm{a}}$ e $5^{\mathrm{a}} \mathrm{RM}$, que enviaram sucessivos contingentes selecionados criteriosamente." ${ }^{, 89}$

Nada o obstante, ao fim da seleção pelas Juntas, foram efetuadas 107.609 inspeções de saúde para a FEB, nas 10 regiões militares do Brasil ${ }^{90}$ e restou especificado que as necessidades desejáveis em pessoal não foram conseguidas, tanto em quantidade, como em qualidade ${ }^{91}$.

\footnotetext{
${ }^{88}$ A propósito da designação do General Mascarenhas de Moraes para organizar e instruir a $1^{\text {a }}$ DIE, transcrevem-se abaixo os telegramas trocados com o Ministro da Guerra sobre o convite para comandar uma divisão brasileira na guerra: “25/H.1- Urgente- 9-VIII-1943- Cifrado- General Mascarenhas de Moraes- São Paulo. Consulto prezado camarada se aceita comando de uma das divisões que constituirão Corpo Expedicionário pt Impõe-se resposta urgente porque caso afirmativo fará estágio Estados Unidos pt General Eurico Dutra- Ministro da Guerra"

“General Dutra- Rio- Urgentíssimo- De São Paulo- 20-40-10-VIII-1943- 17,15 horas. 345- Muito honrado e com satisfação respondo afirmativamente consulta Vossa Excelência acaba fazer-me vg em rádio 25-H-1. (a)- General Mascarenhas de Moraes- comandante $2^{\mathrm{a}} \mathrm{RM}$ ".

${ }^{89}$ Força Expedicionária Brasileira- Relatório Secreto. Volume I- 1943-1945.Pp. 17-18. AHEx. 1 ${ }^{\text {a }}$ D.I.E.- Relatórios.

${ }^{90}$ MAXIMIANO, p.55.

${ }^{91}$ Ao ser o homem identificado, examinado pelos médicos e dentistas, entrevistado e submetido aos devidos testes, eram classificados em quatro grupos:
}

Apto Especial (E)

Apresentando todos os requisitos de aptidão;

Mínimo de 1,60 m de altura para oficiais e 1,55m para praças; 
O Exército se valeria, então, de outro artifício no intuito de preencher os claros nas unidades selecionadas para ir à Itália: passaria a transferir soldados com péssimas fichas de serviços de variadas unidades para os regimentos expedicionários. A FEB se tornaria o destino certo de muitos praças classificados como indisciplinados, ainda segundo Piason:

“(...) Para os já avançados em instrução que saiam, (instrução, é verdade, à moda da casa), cuidou-se de substituir por outros em igual fase de instrução das unidades não expedicionárias. A ordem, baixada assim simplesmente, foi cumprida; mas, nela encontraram as unidades não expedicionárias um ótimo meio para se livrarem de boa parte de seus maus elementos, baseados também na mentalidade de que para eles a guerra era -"castigo" merecido!"92.

O tenente Mário Amaral, que serviu no $6^{\circ} \mathrm{RI}$, faz coro às considerações de seu colega Piason quanto ao aproveitamento de soldados de má conduta para a FEB:

\begin{abstract}
"Certa vez em que o Regimento recebia um contingente de perto de 150 homens vindos de diversas Unidades, o oficial encarregado de sua recepção ordenou: -quem estiver no bom comportamento, levante o braço; os braços permaneceram abaixados; nova pergunta; -- quem estiver no comportamento regular, levante o braço; ninguém se moveu; -- quem estiver no mau comportamento, levante o braço; a só tempo como que movidos por uma satisfação em demonstrar as suas "qualidades", os braços se ergueram em posição vertical.."93
\end{abstract}

No mesmo sentido, se pauta o depoimento ${ }^{94}$, em forma de anedota, contado pelo Marechal Waldemar Levy Cardoso ${ }^{95}$ à edição comemorativa de 60 anos do STM em revista ${ }^{96}$ :

Peso compatível;

Visão sem correção;

Equilíbrio emocional e mental; e

Idade mental de 10 anos.

Apto Normal (N)

Dentro da Normalidade porém sem exigência de critérios rígidos de visão, altura e peso.

Incapaz Temporariamente $(\mathbf{T})$

Portadores de doenças, afecções ou síndromes suscetíveis de tratamento e recuperação a curto prazo.

Incapaz Definitivo (D)

Portadores de doenças, afecções, síndromes que incapacitassem conforme as Instruções Reguladoras das Isenções, Baixa ou Reformas (Aviso ${ }^{\circ}$ 55, de 18 de abril de 1934).

Conforme a categoria, o homem recebia o seu destino determinado:

-Tipo E, destinado à Força Expedicionária Brasileira;

-Tipo N, destinado à outras organizações militares;

-Tipo T, deveria retornar em 30 dias para novo exame e;

-Tipo D, incapacitado para o Serviço Militar.

${ }_{92}$ PIASON, p. 76.

${ }^{93}$ O tenente Mário Amaral serviu no $6^{\circ}$ RI como oficial de ligação com unidades americanas. AMARAL, Mário. "A instrução da FEB”. In: ARRUDA. (Org.), p. 148.

${ }_{94}$ Entrevista realizada em 18 de novembro de 2005 com o Marechal Levy, em sua casa no Rio de Janeiro, in: STM em Revista, Ano 2, n 2, Julho-Dezembro de 2005, Edição “60 anos da atuação da Justiça Militar na Segunda Guerra”.

${ }^{95}$ Nascido em 04 de dezembro de 1900, o então Tenente-Coronel Levy comandou cerca de 400 homens do $1^{\circ}$ Grupo de Artilharia Expedicionária no teatro de guerra da Itália e desempenhou, na conquista de Monte Castelo, o papel de Oficial de Ligação entre a Artilharia Divisionária Expedicionária e o Regimento de Infantaria, encarregado do ataque. 
“(...) durante o período de formação de seu grupo, recebeu soldados de várias unidades, mas, antes de ir para a Itália, fez uma seleção rigorosa e comunicou ao Ministro da Guerra: --"estou deixando no quartel verdadeiros bandidos. O senhor tome providências para nomear um Oficial que tenha pulso para dirigir essa gente".

Nada obstante, além dos óbices apontados, a escolaridade também se mostrou problemática, na medida em que as tropas da FEB restaram integradas, em sua grande maioria, por indivíduos provenientes dos estratos sociais mais baixos da população brasileira, uma vez que -“o Exército pagava mal e frequentemente com atraso, prejudicando assim aqueles que não conseguiam ou não podiam fugir ao tributo de sangue ${ }^{, 97--.}$

A maioria dos filhos dos setores médios e altos da população encontrou meios para evitar a participação na guerra: rapazes em idade de serem convocados casavam-se às pressas, subornavam recrutadores ou conseguiam empregos no governo e eram repentinamente requisitados a permanecer no $\operatorname{Brasil}^{98}$.

Até mesmo doenças, diagnósticos e outros mecanismos eram inventados, forjados para que se evitasse o episódio da guerra, como analisado por Demócrito Cavalcante de Arruda ${ }^{99}$ :

"Essa dança de oficiais no comando, às vésperas do embarque, verificou-se, em pelo menos cinco companhias de fuzileiros das nove existentes no regimento, por motivo de doenças, de cirurgias de última hora. Desses substituídos, só um, baixado por pneumonia, apareceu depois na Itália."

No mesmo sentido, testemunhou o $1^{\mathrm{o}}$ Tenente R2 de Infantaria, Clovis $\operatorname{Garcia}^{100}$ :

“(...) Cabe aqui apontar outra irregularidade: os exames de saúde "encomendados". Exemplo disso tivemos vários, como este ocorrido no III Batalhão do $6^{\circ}$ Regimento de Infantaria. Um jovem $2^{\circ}$ tenente da ativa foi classificado na Força Expedicionária Brasileira. Havia saído há pouco da Escola Militar, necessariamente em condições de saúde satisfatória para ser declarado Oficial. E menos de um mês antes da sua classificação no Regimento, fora em inspeção médica para efeito de sua promoção a $2^{\circ}$ tenente, considerado apto e consequentemente promovido. Incluído no Regimento, foi novamente inspecionado e aprovado. Era um tipo forte, praticando continuamente esportes violentos. Quando, porém, começou a concentração para embarque, com a ida do Regimento para o Rio, tudo indicando a iminência da nossa partida para a

\footnotetext{
96 STM em Revista, Ano 2, $\mathrm{n}^{\mathbf{0}}$ 2, Julho-Dezembro de 2005, Edição “60 anos da atuação da Justiça Militar na Segunda Guerra".

${ }^{97}$ FERRAZ, Francisco César Alves. Os veteranos da FEB e a sociedade brasileira. p. 368.

${ }^{98}$ LOPEZ, Adriana. História do Brasil: uma interpretação. -São Paulo: Editora Senac, 2008. $2^{a}$ edição. p. 693.

${ }^{99}$ Demócrito Cavalcante de Arruda, p.42.

${ }^{100}$ Clovis Garcia, p. 291.
} 
Europa, fomos surpreendidos com uma ordem, em boletim, para que esse jovem e robusto oficial, e somente ele, fosse submetido novamente a exame de saúde. O novo laudo médico considerou-o incapaz, por deficiência cardíaca, sendo então transferido para outra unidade não expedicionária, sediada em um local onde, "coincidentemente", residia a sua noiva, em lugar da sua reforma, como deveria ter acontecido, segundo os regulamentos em vigor. O "mistério" somente começou a esclarecer-se quando soubemos que o pai do referido oficial, coronel do Exército, servia no Gabinete do Ministro da Guerra”.

Essas ausências foram sentidas. Nesse viés, o chefe do Estado- Maior divisionário, coronel Lima Brayner, destaca como um dos principais obstáculos enfrentados a carência de especialistas e técnicos necessários para constituir unidades nos "moldes norte-americanos". Nas suas palavras, eram precisos -"eletricistas, mecânicos, motoristas, operadores e mecânicos de rádio, armeiros, radiotelegrasistas etc..."--. Porém, --“onde encontra-los, não se tratando de elementos de formação normal no âmbito do Exército?"-- ${ }^{101}$.

De fato, segundo a historiadora Maria de Lourdes Lins, numa amostragem de 500 militares da FEB, apenas 7\% teria instrução superior e 17\% formação secundária, concentrados entre oficiais e graduados. A maioria absoluta dos soldados tinha apenas o grau de instrução primário ${ }^{102}$.

Com efeito, a situação social do país exerceu seus efeitos sobre a preparação da tropa. Nos anos 1940, educação escolar secundária era um artigo de alto luxo. De cada mil crianças brasileiras em 1940, apenas trinta haviam passado por escolas ${ }^{103}$.

Contudo, em termos gerais, o nível de formação dos integrantes da FEB era mais alto que o da média da população brasileira ${ }^{104}$, o qual ainda era bastante baixo. Devido à sua natureza mais eminentemente técnica, na arma de artilharia encontravam-se os soldados e oficiais com melhor escolaridade. Pode-se dizer que, levando em conta a realidade social nacional e, em particular, a infantaria da FEB, o Brasil dispunha de -“uma tropa que havia sido bem selecionada, mas pobremente treinada ${ }^{105,--.}$

Por conseguinte, a baixa escolaridade e a insuficiente "qualidade" obtida na seleção dos integrantes da FEB, sem dúvida, cobrou seu preço, afinal, a guerra moderna

\footnotetext{
${ }^{101}$ BRAYNER. A verdade sobre a FEB: memórias de um chefe do estado-maior na campanha da Itália, p. 31.

${ }^{102}$ A historiadora utilizaria os dados fornecidos pela Associação de Veteranos de São Paulo. LINS, Maria de Lourdes F. A Força Expedicionária Brasileira: uma tentativa de interpretação USP, 1975 (dissertação de mestrado), p. 41.

${ }^{103}$ MAXIMIANO, p. 39.

${ }^{104}$ César Campiano Maximiano destaca esse ponto em seu livro ao afirmar que: "Considerando o movimento postal da FEB, a abundância de publicações variadas como panfletos de ordens do dia, volantes de propaganda, manuais de orientações para tropa e o variado número de jornais de trincheira, é possível afirmar que a tropa, em sua maioria, era composta de homens alfabetizados. Milhões de cartas foram trocadas entre a Itália e o Brasil em 15 meses (lembrando que o contingente da FEB e FAB era de cerca de 26 mil homens), e os jornais de trincheira como ... 'E a Cobra Fumou!' e órgãos do comando como o 'Cruzeiro do Sul' eram avidamente procurados pelos homens”. Idem. p. 54 e 55.

${ }^{105}$ FERRAZ, p. 75.
} 
depende mais da formação técnica do que, como no passado, de disposição para o combate e de músculos.

A complexidade do manuseio dos armamentos moderno e, em geral, do equipamento militar de última geração, como o americano, construído para ser operado pela população provavelmente mais instruída do mundo- o ensino básico gratuito e universal foi pioneiramente implantado nos Estados Unidos ainda no século XIX- exigiu um grande esforço de adaptação do soldado brasileiro ${ }^{106}$.

Ademais, a maioria dos soldados da Força Expedicionária Brasileira nunca tinha saído do Brasil. Menos ainda eram os que já tinham visto neve, ou escalado alfo mais alto que uma colina. Um número ainda menor de soldados já tinha alguma vez participado de algum tipo de combate, com uns poucos tendo seu batismo de fogo na revolução de 1924, na perseguição à Coluna Miguel Costa-Prestes e na Revolta Constitucionalista Paulista de $1932^{107}$, além da Intentona Comunista de 1935.

Nenhuma dessas experiências contra forças irregulares, no entanto, mostravase, na prática, adequada para fazer frente ao profissionalismo das Forças Armadas da Alemanha, a Wehrmacht. Os conhecimentos adquiridos em conflagrações de menor vulto só poderiam ser úteis em situações muito limitadas ${ }^{108}$.

De toda sorte, apesar das dificuldades ${ }^{109}$ evidenciadas, e do superficial treinamento que receberam, os soldados apresentavam elevada motivação para realizar as tarefas que lhes eram destinadas.

Nas palavras de um respeitável pesquisador da participação da FEB na Segunda Guerra Mundial -“interpretações apressadas dos relatórios americanos podem fazer crer que a força brasileira era uma tropa completamente destreinada e sem motivação de combate. Os fatos demonstram que não. A FEB foi aprendendo. As missões dadas aos brasileiros foram cumpridas, e que não há dúvida de que, quando acabou a guerra, os pelotões brasileiros de infantaria poderiam ser comparados a quaisquer outros exércitos aliados ${ }^{110,--.}$

\footnotetext{
106 Em verdade, a constituição das unidades designadas foi solucionada com certa engenhosidade, inspirada na experiência americana: para compor o Pelotão de Polícia, foi aberto voluntariado na Guarda Civil de São Paulo; técnicos para os serviços de transmissões foram convocados das companhias de telefonia e eletricidade públicas e o corpo de enfermeiras foi criado a partir do recrutamento de jovens interessadas. Fonte: MAXIMIANO, p. 39.

107 BONALUME, p 120.

${ }^{108}$ MAXIMIANO, p. 47.

${ }^{109}$ A esse respeito: “- (...) o treinamento da Força Expedicionária foi precário, pois a concentração de tropas foi muito tardia, começando em janeiro de 1944 e durando até março, deixando apenas abril e maio para o treinamento da tropa como Divisão"--. Fonte: ALBINO, Daniel. Cobras fumando: a Força Expedicionária Brasileira Brasileira na Campanha da Itália. In: o Brasil e a Segunda Guerra Mundial. Rio de Janeiro: Multifoco, 2010. p. 321.

${ }^{110}$ BONALUME, p. 211.
} 
É possível, de fato, que a FEB tenha apresentado elevado padrão durante a campanha italiana, mas não resta dúvida de que os convocados enfrentaram problemas nem um pouco desprezíveis durante o treinamento no Brasil. Faltavam instalações militares adequadas para recebê-los, assim como equipamentos, ao que se somou a desorganização administrativa.

Relatos atestam, ainda, o elevado grau de incompreensão do país acerca das causas da intervenção brasileira na guerra, o que provocou certa relutância dos cidadãos em compor a FEB ${ }^{111}$.

Segundo o veterano Boris Schnaiderman ${ }^{112}$, mesmo no seio da tropa expedicionária, ninguém se empolgava com o discurso padrão de "vontade de lutar pelas liberdades", "ódio ao inimigo" ou "cumprimento do dever". Ao contrário disso, o que mais se via, segundo o depoente, era uma passividade contagiante, uma aceitação conformada com o destino reservado àqueles que não conseguiram de forma alguma escapar da convocação.

Por essa razão,

“(...) diariamente eram aberto novos claros, mesmo entre oficiais e graduados, pois além dos julgados incapazes, eram retirados os que tinham encargos de família- os casados, os pais mesmo que solteiros, os que já tinham um irmão incorporado ou que concorressem, de algum modo, para auxiliar o sustento da família e, entre vários outros motivos, o de ser portador de doença venérea, facilmente adquirível. A tudo isso se somava a rejeição aos 'má-conduta' (...), mas as que causavam mais revolta eram as exclusões determinadas por apadrinhamentos políticos ou afetivos. Bastava, muitas vezes, um simples apelo para que o suplicante fosse de imediato excluído da Força Expedicionária Brasileira." $" 113$

Segundo Manoel Castello Branco - "os quartéis, com acomodações para 2.000 homens, em média, tiveram que acomodar 3.500"--, o que fez com que os convocados fossem -“comprimidos em pátios e alojamentos, tornando o ambiente interno excitante e desagradável, propício a manifestações de toda ordem, que muito preocuparam os comandos superiores"--. As consequências não tardaram a surgir, dentre elas as fugas, que -“de origem mais sentimental do que disciplinar"--, passaram a ser cada

\footnotetext{
${ }^{111} \mathrm{O}$ ex-combatente, Joaquim Xavier da Silveira (Op. Cit.) fez um interessante resumo das circunstâncias em que vivia o homem brasileiro dos anos 40: “(...) na época em que a FEB foi organizada, a eletrificação rural era praticamente inexistente, o rádio a pilha ainda não tinha sido inventado, as notícias do mundo chegavam como um eco distante. Havia assim uma enorme faixa da população que, dos acontecimentos que originaram a guerra e do envolvimento do Brasil e dos motivos que levaram o País a intervir no conflito, tinha total e completo desconhecimento. Por isso, uma parcela expressiva dos soldados da FEB foi para a Itália sem saber o motivo da guerra, ignorando assim porque lutava (...)." Fonte: SILVEIRA, 136 e 137.

${ }^{112}$ SCHNAIDERMAN, Boris. Guerra em surdina: história do Brasil na segunda Guerra Mundial. 3 ed., São Paulo: Brasiliense, 1995, p. 11, 22 e 89.
} 
vez mais corriqueiras, obrigando o comando a reforçar a vigilância exercida sobre eles, inclusive mediante o recurso à colocação de sentinelas e patrulhas nas estações de trem ${ }^{114}$.

Assim, ao final de toda a mobilização da FEB, o resultado obtido foi a formação de uma tropa expedicionária que refletia a realidade social brasileira, ou seja, uma tropa composta, em sua maioria de soldados pobres, que integrava negros, brancos (a FEB foi à única tropa racialmente integrada), com baixa escolaridade e que pouco sabiam das razões de lutar contra o Eixo ${ }^{115}$.

De acordo com um ex-combatente ${ }^{116}$ :

“A FEB era típica do Brasil em 1944, mas era também um stratum escolhido já que exigia brasileiros com cinco anos de escolaridade, 26 dentes na boca (essa foi a maior causa de rejeição médica), altura de $1,65 \mathrm{~m}$ no mínimo, peso mínimo de $60 \mathrm{~kg}$, e uma saúde aparente boa (os exames psíquicos foram, como se pôde ver depois, deficientes)".

\section{TABELA 1: ${ }^{117}$ DA CONTRIBUIÇÃO DOS ESTADOS PARA A FEB}

\begin{tabular}{|c|c|c|}
\hline ESTADO & $\begin{array}{c}\text { QUANTIDADE DE } \\
\text { HOMENS }\end{array}$ & PORCENTAGEM \\
\hline Distrito Federal $^{118}$ & 6.094 & $16,41 \%$ \\
\hline São Paulo & 3.889 & $12,43 \%$ \\
\hline Minas Gerais & 2.947 & $8.19 \%$ \\
\hline Rio de Janeiro & 1.942 & $7,93 \%$ \\
\hline Rio Grande do Sul & 1.880 & $6,51 \%$ \\
\hline Paraná & 1.542 & $4,03 \%$ \\
\hline Santa Catarina & 956 & $2,89 \%$ \\
\hline Bahia & 686 & $2,86 \%$ \\
\hline Mato Grosso & 679 & $2,75 \%$ \\
\hline Pernambuco & 651 & $1,59 \%$ \\
\hline Ceará & 377 & $1,47 \%$ \\
\hline Paraíba & 349 & \\
\hline
\end{tabular}

${ }^{113}$ ALMEIDA, Cel. Adhemar Rivermar de. Montese: Marco Glorioso de uma trajetória. 1 ${ }^{\text {a}}$-Ed, BIBLIEX, 1985.

${ }^{114}$ CASTELLO BRANCO, Manoel Thomas. A Força Expedicionária Brasileira; p. 145.

${ }^{115}$ A participação brasileira na Segunda Guerra Mundial e a reintegração social dos veteranos de guerra da Força Expedicionária Brasileira: Notas de Pesquisa. Júlia Amabile Aparecida de Souza Pinta e Francisco César Alves Ferraz.

116 BONALUME, p. 126.

${ }^{117}$ MAXIMIANO, p. 407.

${ }^{118} \mathrm{O}$ antigo Distrito Federal, depois Estado da Guanabara, é, hoje, capital do Estado do Rio de Janeiro. 


\begin{tabular}{|c|c|c|}
\hline Espírito Santo & 345 & $1,46 \%$ \\
\hline Rio Grande do Norte & 341 & $1,44 \%$ \\
\hline Pará & 281 & $1,19 \%$ \\
\hline Sergipe & 192 & $0,81 \%$ \\
\hline Alagoas & 148 & $0,62 \%$ \\
\hline Maranhão & 134 & $0,57 \%$ \\
\hline Goiás & 111 & $0,47 \%$ \\
\hline Amazonas & 91 & $0,38 \%$ \\
\hline Piauí & 67 & $0,28 \%$ \\
\hline
\end{tabular}

Como a FEB foi constituída de soldados de todos os Estados da Federação havia, portanto, uma grande heterogeneidade de fenótipos na tropa, desde os descendentes de germânicos do Sul aos caboclos do Centro-Oeste. Era a diversidade da composição da sociedade brasileira refletida em verde-oliva para a guerra.

O efetivo total da FEB foi de 25.334 pessoas, representantes de 21 estados brasileiros $^{119}$, cujo número de combatentes se restringiu a $15.069^{120}$, integrada, em maior número, por habitantes do Sul e do Sudeste do Brasil ${ }^{121}$ e por moradores da região urbana $^{122}$, que lutaram durante longos meses naquele teatro operacional, conforme se detalha no capítulo subsequente.

\section{(iv) Síntese das ações da Força Expedicionária Brasileira na Itália.}

Quando chegaram à Itália, as tropas da FEB encontraram um país em plena guerra civil, pois havia sido deposto Mussolini em 08 de setembro de 1943 e firmado um armistício com os aliados. A Itália estava arruinada e, perdedores no conflito, os italianos não mais se identificavam com antigo líder, odiando-o tanto quanto o tinham amado ${ }^{123}$.

\footnotetext{
${ }^{119}$ MASCARENHAS DE MORAES, p. 313.

${ }^{120}$ A participação brasileira na Segunda Guerra Mundial e a reintegração social dos veteranos de guerra da Força Expedicionária Brasileira: Notas de Pesquisa. Júlia Amabile Aparecida de Souza Pinta e Francisco César Alves Ferraz.

${ }^{121}$ Tais regiões foram favorecidas por dois motivos principais: em primeiro lugar, as unidades escolhidas para compor a Infantaria Divisionária estavam sediadas nos Estados do Rio de Janeiro, São Paulo e Minas Gerais, em função das análises que conferiram $\mathrm{m}$ grau mais avançado de prontidão. Outra razão foi o melhor estado geral de saúde dos convocados das áreas mais ao sul do país. A seleção para a FEB tornou ainda mais transparente a triste realidade dos baixos padrões de vida no Norte e Nordeste brasileiros. Fonte: MAXIMIANO, p.56.

${ }^{122}$ A eficácia do recrutamento dependeu da capacidade do Estrado de chegar até os convocados. As cidades onde o recrutamento se mostrou mais eficiente foram justamente aquelas alcançadas pela malha ferroviária nos anos 40 . Fonte: Idem. p.59

${ }^{123}$ INNOCENTI, Marco. Ciano- Il fascista che sfidò Hitler. Milano: Ugo Mursia, 2013. p. 117.
} 
Mussolini foi libertado pelos alemães e instalado na chamada República de Salò. Tropas fascistas em número expressivo lutavam ao lado dos alemães, que efetivamente controlavam as áreas não libertas da Itália. Gradativamente, tropas italianas também foram introduzidas ao lado dos Aliados, no qual já se contava um contingente importante de partigiani engrossado por cerca de 5 mil voluntários soviéticos ${ }^{124}$. Tratavase, em verdade, de uma verdadeira guerra civil.

$\mathrm{Na}$ ocasião, a Itália estava devastada pela guerra; os italianos passavam por dificuldades indescritíveis, uma vez que as cidades tinham sido duramente bombardeadas pela aviação e pela artilharia das forças aliadas, estando semidestruídas.

O povo italiano, desesperançado, passava frio, fome e sede, mas não perdia o sentido da crítica e cantava -"Mussolini, o Duce que nos conduz, de dia falta pão e à noite falta a luz"--.

A FEB foi uma das 20 divisões aliadas a combater naquele período no teatro de operações da Itália, integrada ao $4^{\circ}$ Corpo de exército norte-americano, subordinado ao V Exército dos Estados Unidos. Entre as tropas que combateram ao lado da FEB estavam os quadros segregados das $92^{\mathrm{a}}$ (negros) ${ }^{125}$ e $442^{\mathrm{a}}$ (nipônicos) divisões norte-americanas, bem como tropas italianas antifascistas, de colônias britânicas e também as francesas.

Os febianos tiveram seu batismo de fogo no mês de setembro de 1944. A primeira fração da FEB a entrar em combate na Itália foi o $6^{\circ}$ Regimento de Infantaria ("6 $6^{\circ}$

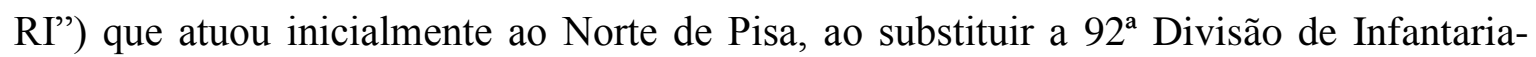
composta por soldados negros, embora comandada por oficiais brancos- no dia 15 de setembro daquele ano- que operava em situação crítica pela carência de infantaria, já que sete divisões haviam sido transferidas para o teatro francês de operações (Operação Overlord).

Após um mês e meio de atuação, o $6^{\circ}$ RI liberou algumas cidades e vilas italianas, fazendo 243 prisioneiros alemães e italianos ao custo total de 30 mortes, dentre os quais 03 oficiais, além de 93 feriados e 10 desaparecidos. A primeira cidade liberada pela FEB foi Massarosa, em 16 de setembro de 1944, que era um relevante entroncamento

\footnotetext{
${ }^{124}$ SEMIRIAGA, M. I. Missão libertadora das forças armadas soviéticas na Segunda Guerra Mundial. Rio de Janeiro: Livraria Ciência e Paz, 1985. p. 31.

${ }^{125}$ A esse respeito, cumpre destacar que a FEB era a única formação racialmente integrada o campo de batalha. $\mathrm{O}$ contraste era flagrante com a $92^{a}$ Divisão de Infantaria americana, formada por negros mas com oficiais brancos, como se fosse uma unidade colonial (os indianos no Exército britânico tinham oficiais europeus, assim como os senegaleses e marroquinos tinham oficiais franceses). A divisão era chamada "Divisão búfalo", porque esse era o apelido dos soldados negros, dados pelos índios americanos no século XIX. Para os nativos, a pele escura e o cabelo crespo dos soldados negros lembravam o búfalo. Fonte: BONALUME, p 130.
} 
ferroviário e rodoviário, importantíssimo estrategicamente ${ }^{126}$, que ficava nos contrafortes dos Apeninos, ligação norte-sul na consta mediterrânea noroeste da Itália.

Nesse primeiro momento, contudo, a tomada mais importante foi a da cidade de Camaiore, com população de 5.000 habitantes ${ }^{127}$. Para tomá-la foram empregados 100 homens que, após enfrentarem fogo de morteiro e canhões, fizeram com que os alemães a abandonassem $^{128}$. Naquela região operava, na ocasião, a tão veterana quanto experiente $148^{a}$ divisão alemã, que era apoiada pelas divisões fascistas "Itália", "San Marco" e "Monte Rosa", e contava ainda com elementos de diversos outros agrupamentos fascistas idiossincráticos.

No início de suas atividades, a FEB encontrou menores dificuldades, pois as tropas alemãs estavam a se retirar para uma posição defensiva fortificada mais ao norte, na região montanhosa dos Apeninos ${ }^{129}$.

Posteriormente, quando os alemães empreenderam a habitual tenaz e sistemática resistência nas novas posições fortificadas montanha acima, os brasileiros enfrentaram aquele que, até então, seria o seu maior teste na Itália: Monte Castelo ${ }^{130}$.

A batalha em torno da célebre elevação, alvo de cinco ataques, não foi, contudo, a mais sangrenta da guerra para os brasileiros --posto herdado pela tomada de Montese, que causou o maior número de baixas --, mas sem dúvida foi a mais importante pelo seu simbolismo. No entendimento dos Comandantes militares brasileiros, tomar o Monte Castelo representaria a chave para a evolução da ofensiva aliada no setor da península italiana na qual se encontravam ${ }^{131}$.

A partir de Montese, conquistada em 14 de abril de 1945, a $1^{\text {a }}$ DIE lançou-se em um movimento do leste, próximo ao Adriático, onde estava, de retorno para o oeste, de onde partira, de volta em direção ao Mediterrâneo e ao porto de Gênova, para tentar cortar a retirada das tropas alemãs que se dirigiam para o norte da Itália em direção à Alemanha. Nesse difícil avanço de 209 quilômetros, feito em poucos dias em situação adversa, a FEB

\footnotetext{
${ }^{126}$ Massarosa controlava a rodovia e a ferrovia que, da costa, levavam a Pistoia, a Florença e a Bolonha, importante centro industrial e comercial das proximidades do mar Adriático.

${ }^{127}$ Por ser a primeira cidade de algum vulto tomada pela FEB, mereceu destaque da imprensa no Brasil. Uma maneira simples de acompanhar como foi noticiada a campanha é a seleção de reproduções das primeiras páginas de 'O Globo', no livro 'O Globo Expedicionário', da Agência Globo.

128 BONALUME, p. 138 e 139.

129 A Linha Gótica ia de Pisa, no litoral toscano, até Rimini, no litoral adriático, cortando a península itálica de oeste a leste, mas era situada, na sua maior parte, no terreno montanhoso dos Apeninos.

${ }^{130}$ A descrição dos combates em Monte Castelo encontra-se em: BONALUME, p. 172 e ss.

${ }^{131}$ MAXIMIANO, p. 92.
} 
liberou Alessandria, importante entroncamento situado a apenas $50 \mathrm{~km}$ a noroeste de Gênova, objetivo estratégico dos aliados, e Fornovo ${ }^{132}$.

Nessa localidade, a FEB entrou novamente em contato com a $148^{\mathrm{a}}$ Divisão de Infantaria Alemã, fechando o cerco e cortando sua retirada para o Norte, encurralando-a pela retaguarda, contra os Apeninos, até a rendição incondicional feita pelo general Otto Fetter Pizo ${ }^{133}$, fato que preconizou o maior feito da FEB de repercussão estratégica no conflito $^{134}$.

No dia 27 de abril de 1945, Mussolini foi preso pelos partigiani italianos, portando expressiva quantidade de ouro e libras esterlinas, quando tentava evadir-se para a Alemanha, vestido de soldado em um comboio alemão, tendo sido fuzilado no dia seguinte $^{135}$. Seu corpo mutilado foi exposto na Piazzale Loreto, em Milão, junto com o de sua amante, Claretta Petacci ${ }^{136}$.

Acabou, assim, a infausta aventura do fascismo, que desgraças, desventuras e sofrimentos levou ao povo italiano. Da mesma maneira, concluiu-se a ação da tanto artificial como bizarra República de Salò ${ }^{137}$, governo fascista instaurado pelos alemães na parte setentrional do país por eles controlada após a rendição da Itália, em 28 de agosto de 1943.

Em meados de abril, as tropas do Exército Vermelho, sob o comando do marechal Georgy Zhukov, atingiram Berlim ${ }^{138}$. A capital alemã, uma cidade cuja população antes da guerra era de 4,5 milhões tinha caído na ocasião para cerca de 3 milhões, dos quais 2 milhões eram mulheres e 120 mil crianças.

Na ocasião, as tropas aliadas ainda não haviam alcançado a linha do rio Pó, no norte da Itália, em virtude da tenaz resistência alemã, ao difícil terreno e operações. Destarte, pode-se concluir que a vitória final e decisiva no teatro de operações da Itália foi causada pelo sucesso das tropas soviéticas na Alemanha, quando desmoronaram as forças armadas alemãs que ainda resistiam no norte da Itália.

$\mathrm{Na}$ fase final da campanha na Itália, tropas da FEB chegaram a Turim, na região do Piemonte, para posteriormente avançar até a fronteira italiana com a França,

\footnotetext{
${ }^{132}$ CLARK E CLARK, Mark Wayne e Mark. Il comandante dela V armata. Associazione Culturale Sarasota. p. 461.

${ }^{133}$ Legião Paranaense do Expedicionário, Roteiro da Força Expedicionária Brasileira na Camapanha da Itália, Imprensa Oficial, s/d.

${ }^{134}$ BENTO, Claudio Moreira (Org.), p. 405.

${ }^{135}$ HIBBERT, Christopher. Mussolini, the rise and fall of il Duce. Nova York: Palgrave Macmillan, 2008.

${ }^{136}$ MONTI, Luisa Sturani. Antologia della Resistenza. Torino: Centro del Libro Popolare, 1951.p. 293.

${ }^{137}$ Pequena cidade na margem ocidental do lago de Garda.

${ }^{138}$ ROBERTS, Geoffrey. Stalin's General- The Life of Georgy Zhykov. Londres: Icon Books, 2012. p. 224 e ss.
} 
novamente em região montanhosa dos Alpes Mediterrâneos, onde fizeram o encontro de junção com as tropas deste país.

O ditador Adolf Hitler suicidou-se no seu abrigo bunker, em Berlim, no dia 01 de maio de $1945^{139}$. Na mesma data do suicídio de Hitler, Joseph Stalin, ditador soviético, anunciou a queda de Berlim para o mundo ${ }^{140}$. As tropas alemãs renderam-se às forças aliadas no dia 7 de maio de 1945, em Berlim, terminando a fase europeia da $2^{\text {a }}$ Guerra Mundial $^{141}$.

Pela ocasião da rendição das tropas alemãs e fascistas aos Aliados e a consequente cessação das hostilidades, o general João Batista Mascarenhas de Moraes baixou sua ordem ${ }^{142}$ do dia, publicada no Boletim Interno $\mathrm{n}^{\mathrm{o}} 123$, de 3 de maio de 1945 , da $1^{\text {a }}$ DIE, que passaria para a História, na qual afirmou, com sensibilidade:

\begin{abstract}
“(...) Hoje, é quase toda a humanidade que se ajoelha contrita, espírito reanimado pela esperança, coração revivido pela fé e pensamento voltado para a reconstrução do mundo e o bem da coletividade. (...)

Eu me sinto justamente orgulhoso de vos ter comandado nessa memorável campanha e considero a presente oportunidade o maior e melhor prêmio que poderia receber pelos meus 46 anos de efetivo serviço ao Exército e ao Brasil. Vós também podereis estar orgulhosos de terdes cumprido dignamente o vosso dever e concorrido brilhantemente para que à nossa Pátria fosse reservado um lugar na reconstrução do Mundo. E com orgulho sem jactância, e confiança sem exageros, retornemos aos nossos lares, aos nossos quartéis e postos de trabalho, para prosseguirmos na faina sagrada de fazer um Brasil forte e respeitado, num mundo livre e feliz".
\end{abstract}

Seria responsável, o aludido e saudoso comandante de transmitir, ainda, dois telegramas sobre o fim da guerra na Itália, às duas mais altas autoridades no que concerne à defesa da soberania do país, os quais se passa a transcrever a seguir:

\begin{abstract}
Ao Presidente da República
Dr. Getúlio Vargas- Palácio do Catete, Rio, Brasil- M- 164- Em 5-5-1945.

Com o encerramento dia dois corrente Campanha do Teatro Operações da Itália vg com fulminante e integral vitória Armas Aliadas vg em cujo âmbito forças brasileiras tiveram desempenho à altura da confiança que lhe foi outorgada pela Nação vg sinto-me orgulhoso tê-la comandando em tão transcendentes circunstâncias pt Cumprida nossa árdua missão vg estamos liberados para regressar Pátria vg com consciência tranquila por tê-la bem servido vg atraindo para seu nome glorioso estima e respeito dos povos que amam liberdade pt Congratulando-me com vossência vg chefe Nação Brasileira vg por nos ter proporcionado o excepcional ensejo de revelar mundo civilizado determinação dos nossos soldados em cumprir sagrados compromissos sua Pátria pt fim
\end{abstract}

\footnotetext{
${ }^{139}$ RYAN, Cornelius. The Last Battle. Estados Unidos: Popular Library, 1966. p. 507.

${ }^{140}$ ROBERTS, p. 230.

${ }^{141}$ No teatro asiático, o Japão rendeu-se incondicionalmente em 2 de setembro de 1945, na baía de Tóquio.

${ }^{142}$ MASCARENHAS DE MORAES, p. 220-ss.
} 


\begin{abstract}
Ao Ministro da Guerra
General Eurico DUTRA- Ministro da Guerra, Rio, Brasil- M- 163- Em 5-51945.

Com encerramento a dois Campanha Armas Brasileiras Teatro Operações Itália vg sinto-me possuído mais justo e orgulho e congratulo-me com vossência pelos feitos praticados pelos nossos soldados vg que fizeram jus à admiração e à gratidão da humanidade angustiada pt Bendigo destino reservou a mim suprema glória comandá-los nesta trágica encruzilhada da vida dos povos pt É pois vivamente emocionado que asseguro a vossência que eles fizeram jus à imorredoura gratidão da Pátria pt Prontos a regressar ao recesso dos lares patrícios vg levarão consigo a certeza de terem feito pelo Brasil vg todo o trabalho de uma geração que não os esquecerá jamais pt fim
\end{abstract}

A FEB, contou com um efetivo total de 25.445 soldados em solo italiano, dentre os quais 465 morreram e 2722 foram feridos em 239 dias (setembro de 1944 a maio de 1945). Como fruto de sua atuação, acolheu um contingente de 20.573 combatentes alemães e fascistas italianos, entre os quais dois generais, 892 oficiais, 80 canhões, 5 mil viaturas e 4 mil cavalos, número que equivalia ao próprio contingente da força expedicionária brasileira.

Durante a guerra, os brasileiros mortos em combate foram sepultados em dois outros cemitérios além do de Pistoia. Somente após a cessação das hostilidades foram todos os expedicionários mortos trasladados para o Cemitério Militar Brasileiro ${ }^{143}$.

Em aviso 217-185, de 06 de julho de 1945, o então Ministro da Guerra determinou que as unidades da FEB ficassem, desde sua chegada ao Rio de Janeiro, subordinadas ao general comandante da $1^{\text {a }}$ Região Militar. A decisão, por certo, subtraía o comando do General Mascarenhas de Moraes e desmobilizava a tropa.

Consoante preceituava o aludido documento ministerial, na medida em que as unidades expedicionárias desembarcassem no Rio de Janeiro, os seus elementos integrantes tomavam novos destinos, retornando às atividades do tempo de paz.

Quando viram, já era tarde para a adoção de diversas medidas, conquanto muitas das experiências adquiridas em campanhas se perderam, não foram aplicadas nem transmitidas a outras unidades do Exército. A observação incluída em documento secreto $^{144}$ do comando americano, que considerava a FEB capaz de transmitir as

\footnotetext{
${ }^{143}$ MAXIMIANO, p.151.

${ }^{144}$ O Departamento de Guerra americano enviou, em 06 de abril de 1945, correspondência ao general comandante das forças do Exército dos EUA no Atlântico Sul, sob as quais as tropas brasileiras se viam subordinadas, alertando para a inconveniência da desmobilização imediata da Força Expedicionária Brasileira ("FEB") quando do seu retorno ao Brasil. Observavam no comentado documento que -"uma vez que é a única unidade do Exército brasileiro inteiramente treinada pelos EUA, considera-se que tem grande valor como um núcleo para o treinamento de outros elementos do Exército brasileiro e como uma contribuição potencialmente valiosa do Brasil à defesa hemisférica."

Em que pese a preocupação exposta pelos Estados Unidos e, mesmo compartilhando com a máquina de guerra daquele país, os planejamentos e a execução de todas as etapas de combate, nenhuma ação de reintegração social dos "pracinhas"
} 
experiências de campanha, não foi aceita. A política de executar a imediata desmobilização da FEB se sobrepunha a qualquer outra consideração.

A determinação ministerial significou, portanto, em última análise, a formal dissolução da Força Expedicionária Brasileira.

Tabela 2: Resumo da campanha da FEB na Segunda Guerra Mundial

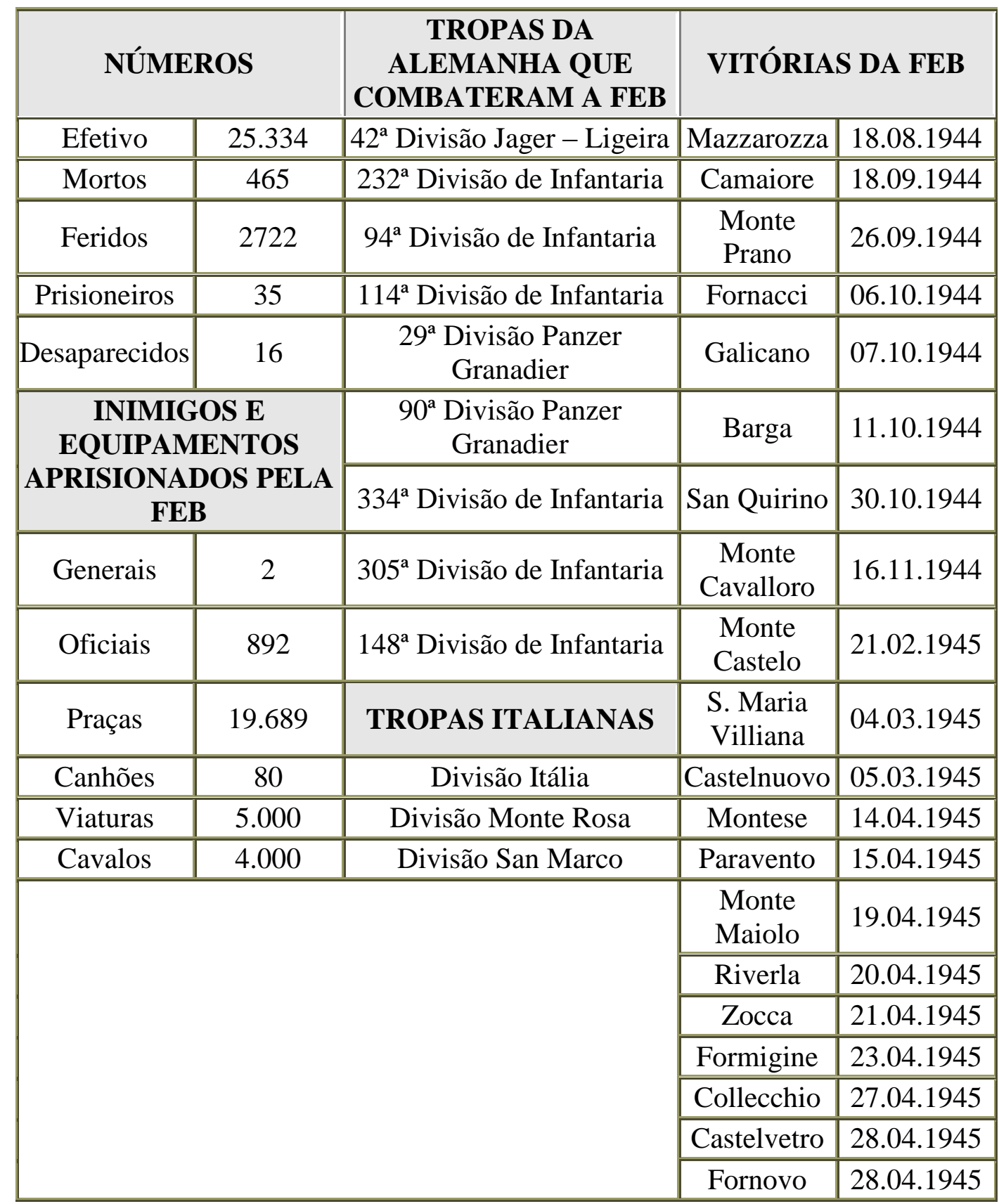

Fonte: www.exercito.gov.br (18.03.2016)

veio a ser preparada pelo Governo brasileiro , tendo as autoridades militares brasileiras optado por desmobilizar sumariamente a FEB. Fonte: FERRAZ, Francisco César Alves. A guerra que não acabou: a reintegração social dos veteranos da Força Expedicionária Brasileira. 2003. Tese (Doutorado em História)- Faculdade de Filosofia, Letras e Ciências Humanas, Universidade de São Paulo, São Paulo. 


\title{
II. A JUSTIÇA MILITAR BRASILEIRA
}

\begin{abstract}
"A justiça tem numa das mãos a balança em que pesa o direito e, na outra, a espada de que se serve para defendê-lo. A espada sem a balança é a força brutal; a balança, sem a espada, é a impotência do direito". (Revista do Ministério Público Militar. - Ano 1, n. 1 (1974)- ano 36, n. 21 (abr. 2010). pg. 178.- Brasília: Procuradoria-Geral de Justiça Militar, 1974)
\end{abstract}

\section{(i) Histórico da Justiça Castrense no Brasil.}

No Brasil, a Justiça Militar existiu antes mesmo da Justiça Comum, tendo chegado a bordo das primeiras naus portuguesas.

O direito militar, noticia-se, tem o seu início na época colonial da História do Brasil, quando os antigos donatários exerciam o poder militar (relativos às armas, artilharia, pólvora, salitre, enxofre, chumbo e munições de guerra) em suas terras, os quais lhes eram delegados pela própria Coroa Portuguesa ${ }^{145}$.

Tem-se conhecimento de que a Carta de Doação de 10.03.1534 e o Foral de 4 de setembro foram os primeiros documentos escritos da legislação militar, advindo, em seguida, as disposições do Regimento do Governo Geral do Brasil de 17 de dezembro de 1534, destinado a Tomé de Souza, com cunho essencialmente militar ${ }^{146}$.

Vigoravam no Brasil as Ordenações Filipinas e os Artigos de Guerra do Conde de Lippe. A esse respeito, cumpre destacar que, em 1763, o Conde de Lippe ${ }^{147}$, a pedido do Marquês de Pombal, condensou a dispersa legislação penal militar portuguesa e produziu os Códigos de Guerra ${ }^{148}$, que previam penas severas e castigos corporais, próprios da época, como o arcabuzamento e os pranchaços.

Conquanto a primeira legislação penal militar no Brasil refira-se aos Artigos de Guerra do Conde de Lippe, aprovados em $1763^{149}$, foi a vinda da família real

\footnotetext{
${ }^{145}$ TEIXEIRA, Sílvio Martins. Código Penal Militar. Rio de Janeiro: Freitas Bastos, 1946.

${ }^{146}$ ROMEIRO, Jorge Alberto. Curso de Direito Penal Militar: parte geral. São Paulo: Saraiva, 1994.

${ }^{147}$ Schaumburg-Lippe, oficial alemão, convidado pelo rei D. José I, de Portugal, para ordenar o exército (apesar de alemão, alistou-se e destacou-se como oficial na Marinha Inglesa). Conhecido como Conde de Lippe, Marechal General dos Exércitos de Portugal. Elaborou os Regulamentos para Infantaria, Cavalaria e os chamados Artigos de Guerra, utilizados no Brasil até a entrada em vigor dos Códigos pátrios versando sobre o direito penal militar. O regulamento dispunha sobre diversas áreas da atividade militar: a questão disciplinar, composição dos exércitos, dos pagamentos, da carreira militar, do manuseio de armas, da organização para os dias de festa, etc. Entretanto, o regulamento do Conde de Lippe é conhecido pela crueldade das penas impostas, como chicotadas e pranchadas.

${ }^{148}$ ROMEIRO, p.33.

149 Os Artigos de Guerra foram inspirados nos Artigos de Guerra da Alemanha, que remontavam aos da Inglaterra de 1621, de Gustavo Adolfo. Compunha-se de vinte e nove artigos, compreendendo as penas de arcabuzamento, expulsão com infâmia, morte, cinquenta pancadas de espada de prancha, etc.
} 
portuguesa à terra brasileira, motivada pelo avanço das tropas do Général Junot, que acabou por instalar formalmente a Justiça Militar no Brasil ${ }^{150}$.

Assim, convém asseverar que o período joanino (1808-1821), momento-chave da emancipação política do Brasil colônia, teve sua gênese na decisão da Coroa Portuguesa de não aderir, no ano de 1806, ao Bloqueio Continental decretado por Napoleão Bonaparte, numa tentativa de isolar e asfixiar economicamente o Reino Unido.

Consoante os termos ditados pelo Imperador francês, normatizado em 21 de novembro de 1806 com a emanação do decreto de Berlim, os países então submetidos ao domínio do Primeiro Império Francês (1804-1814) deveriam impedir o acesso de navios do Reino Unido da Grã-Bretanha e Irlanda a seus portos, numa forma de evitar o estabelecimento de quaisquer relações comerciais junto àqueles países.

Os portugueses, contudo, dependentes da economia britânica e fortemente pressionados por seus credores, optaram por não aderir ao bloqueio. A nação portuguesa se viu, então, entre as pressões britânicas, cuja assistência se mostrava indispensável, tanto econômica como militarmente, e a França, cada vez mais ameaçadora ${ }^{151}$. Não tardou até que, em 27 de outubro de 1807, a França assinasse o Tratado de Fontainebleau ${ }^{152}$ com a Espanha, estipulando a invasão de Portugal, além de acordos para a posterior divisão do Reino Português e seus domínios signatários.

Diante da iminente invasão de seu território, em novembro de 1807, quando as tropas de Napoleão já estavam nas cercanias de Lisboa, D. João- ainda como príncipe regente- tomou a decisão de, juntamente à corte portuguesa, deixar Portugal rumo ao Brasil, que veio a se tornar, a partir de então, sede da monarquia portuguesa ${ }^{153}$.

Assim sendo, o ano de 1808 deu início a um processo que, em 1815, definiuse juridicamente, em nível internacional, pela elevação do Brasil à categoria de Reino Unido a Portugal e Algarves: a colônia se transformara num Estado autônomo, com seu próprio mecanismo de governo e o direito de autodeterminação na política econômica ${ }^{154}$.

A Metrópole e a colônia estavam unidas, mas no curso dos acontecimentos a colônia se tornaria efetivamente a "Pátria-Mãe", num processo que restaria denominado

\footnotetext{
${ }^{150}$ ASSIS, Jorge César. Direito militar: aspectos penais, processuais penais e administrativos. Curitiba: Juruá, 2007.

${ }^{151}$ MARQUES, Antônio Henrique Rodrigo de Oliveira, História de Portugal, Volume I. Edições Àgora, Lisboa, 1973, p. 576.

${ }_{152} \mathrm{http} / / /$ seuhistory.com/hoje-na-historia/foi-firmado-o-tratado-de-fontainebleau acesso em 02.05.2016.

${ }^{153}$ LIMA, Manoel de Oliveira. D. João VI no Brasil. Rio de Janeiro: Topbooks, 1996.

${ }^{154}$ MARQUES, p. 580.
} 
como “inversão da metrópole"155, na medida em que a Administração Pública Portuguesa se encontrava em solo brasileiro.

Ao chegar ao Brasil no século XIX, foi possível à corte portuguesa vislumbrar que sua colônia era povoada, praticamente, por indígenas e negros. Inexistia qualquer avanço tecnológico. Não havia ensino superior, imprensa, indústria, serviços públicos. Contudo, em menos de dois meses após a chegada da família real, tal cenário foi modificado $^{156}$.

Foram criadas várias instituições que inexistiam até então, como a Guarda Real, a Biblioteca Nacional, faculdades de engenharia e medicina, o Banco do Brasil e o Jardim Botânico. Contudo, a primeira grande medida tomada por D. João no Brasil, através da Carta Régia de 28 de janeiro de 1808, foi a abertura dos portos às nações amigas, o que beneficiou a Inglaterra, dada a ruptura com o pacto colonial que outrora se estabelecera.

A segunda grande medida de impacto tomada pelo monarca português deu-se com a assinatura do alvará de $1^{\circ}$ de abril de 1808, também conhecido como o alvará da liberdade industrial, por meio do qual se autorizou o livre estabelecimento de fábricas e manufaturas no Brasil, rompendo-se a lógica do pacto colonial, que vedava a livre atividade industrial no país.

Ademais, por meio da assinatura do Alvará Régio com força de lei de abril de 1808, o príncipe regente D. João criou também, o Conselho Supremo Militar e de Justiça, na cidade do Rio de Janeiro, primeiro Tribunal Superior de Justiça instituído no Brasil (Anexo n. 2), presidido por D. José Xavier de Noronha Camões de Albuquerque Souza Muniz, Marquês de Angeja, Conde e Senhor de Vila Verde ${ }^{157}$.

Estava implantada, assim, a Justiça Militar no Brasil, representada pela mais antiga Corte de Justiça do País, com jurisdição em todo o território nacional, gênese do atual Superior Tribunal Militar ${ }^{158}$.

\footnotetext{
${ }^{155}$ CALMON, Pedro. História do Brasil. Rio de Janeiro: José Olympio Editora, 1961.

${ }^{156}$ Coletânea de Estudos Jurídicos. Publicação em comemoração ao Bicentenário da Justiça Militar no Brasil./ Maria Elizabeth Guimarães Teixeira Rocha, Zilah Maria Callado Fadul Petersen, coordenadoras; Samantha Ribeiro Meyer Pflug, colaboradora.- Brasília: Superior Tribunal Militar, 2008. 831 p.

${ }_{157}$ BARBOSA, Raymundo Rodrigues. História do Superior Tribunal. Rio de Janeiro: Departamento de Imprensa Nacional, 1952.

${ }^{158}$ Naquele tempo, chamava-se Conselho Superior Militar e de Justiça e era presidido pelo próprio príncipe regente. Os imperadores Pedro I e Pedro II, filho e neto de D. João VI, também o presidiram, assim como os marechais Deodoro e Floriano Peixoto, nos primeiros anos da república. Com essa observação, ressalta-se a importância desse órgão para Portugal e para o Brasil. Apenas em 1893, por meio da edição do decreto legislativo $n^{\circ} 149$, que a presidência da instituição passou a ser assumida por um dos seus integrantes, eleito por seus pares, e não mais por um representante do governo, como era o caso do Conselho Supremo Militar e de Justiça, presidido pelo imperador, concedendo certo grau de autonomia à instituição, desvinculando-a, formalmente, da esfera política. Integraram também o Superior Tribunal Militar, além dos já citados Chefes de Estado, outras personalidades, eminentes brasileiros cujos nomes estão inseridos
} 
Criada, portanto, no ano de 1808, a Justiça Militar foi inicialmente organizada em torno de duas instâncias: os Conselhos de Guerra e o Conselho Supremo Militar e de Justiça ("CSMJ") ${ }^{159}$, que acumulava funções de caráter administrativo e jurídico ${ }^{160}$, espelhando o modelo existente na metrópole desde 1640 e configurando-se como uma herança portuguesa amparada na tradição do Antigo Regime ${ }^{161}$.

O mais antigo tribunal superior do País, CSJM, funcionava na cidade do Rio de Janeiro, cumulando as funções de (i) Supremo Conselho Militar, compondo-se, de nove Conselheiros de Guerra e de três Vogais, com amplas atribuições de cunho administrativo $^{162}$ e; (ii) de Supremo Tribunal de Justiça, formado pelos mesmos Conselheiros e Vogais, além de outros três Juízes togados, com funções circunscritas ao conhecimento, em reexame necessário, dos processos oriundos dos Conselhos de Guerra e atribuições relacionadas à defesa da corte e da colônia.

O primeiro grau da Justiça Militar, a seu turno, esteve organizado desde a sua criação em Juntas ou Conselhos mistos, que compunham os Conselhos de Guerra. A partir de 1813, esses Conselhos, que até então funcionavam apenas no Rio de Janeiro, passaram a operar em outras localidades. Eram compostos por um oficial superior, que o presidia, um auditor e cinco oficiais militares, num total de sete membros ${ }^{163}$.

Contudo, o tempo e as mudanças ocorridas, inclusive no status político do Brasil, contribuíram para a transformação da Justiça Militar, cuja estrutura e competência foi submetida a diversas modificações até atingir as configurações atuais.

Em verdade, seu périplo institucional foi longo, conforme se passa a expor em breve análise de sua presença nas Constituições brasileiras.

\footnotetext{
na história do Brasil, tais como: Duque de Caxias, o Patrono do Exército; o Almirante Tamandaré, o Patrono da Marinha; o Dr. Joaquim Pedro Salgado Filho, que em 1941, com a criação de uma nova Força Armada, deixou o Tribunal para assumir o cargo de Ministro da Aeronáutica; e, mais recentemente, renomados juristas, dentre os quais se destaca o Dr. João Romeiro Neto; o Dr. João Mendes da Costa Filho e o Dr. Alcides Vieira Carneiro (fonte: Coletânea de Estudos Jurídicos. Publicação em comemoração ao Bicentenário da Justiça Militar no Brasil./ Maria Elizabeth Guimarães Teixeira Rocha, Zilah Maria Callado Fadul Petersen, coordenadoras; Samantha Ribeiro Meyer -Pflug, colaboradora.- Brasília: Superior Tribunal Militar, 2008. p.89 e 90)

${ }^{159}$ Desde sua origem, a Organização Judiciária Militar brasileira adotou o princípio do duplo grau de jurisdição, ou seja, estrutura em duas instâncias. Para maiores informações sobre a história da Justiça Militar Brasileira ver: CASTRO, Therezinha de. José Bonifácio e a Unidade Nacional. Rio de Janeiro: Biblioteca do Exército Editora, 1984.

${ }^{160}$ Ao mesmo tempo em que julgava os processos criminais, desempenhava atividades como, por exemplo, concessão de patentes, requerimentos de reforma, de pensão, de promoção, lavratura de patentes e uso de insígnias, sobre as quais se manifestava por meio de parecer, quando consultado.

${ }^{161}$ O Conselho Supremo Militar e de Justiça de Portugal teve origem em 11 de dezembro de 1640, sob a denominação de Conselho de Guerra e se regulava pelo Regimento de 22 de dezembro de 1643 (Resoluções e Ordens Régias do Conselho de Guerra de Lisboa), transformando-se em Conselho Supremo em 20 de agosto de 1777 e, entre outras atribuições, funcionava como Tribunal de Apelação para certos crimes praticados por militares. Ver: PESSÔA, Ruy de Lima. Superior Tribunal Militar. Revista do Superior Tribunal Militar. Brasília, 1988.

${ }_{162} \mathrm{Na}$ função de caráter administrativo eram discutidas questões referentes a requerimentos, cartas-patentes, promoções, soldos, reformas, nomeações, lavratura de patentes e uso de insígnias, sobre as quais manifestava seu parecer.

${ }^{163}$ FREITAS, Ricardo. Memória histórica do Ministério Público Mililtar.- Brasília: MPM, 2012.
} 
A primeira Constituição do Império do Brasil, de 25 de março de 1824, outorgada por D. Pedro I, foi a primeira Carta Magna brasileira a prever a existência do Poder Judiciário ${ }^{164}$, a sua organização e a competência, de acordo com o - "Título $6^{\circ}$ - Do Poder Judicial- Capítulo Único- Dos Juízes e Tribunais de Justiça"--. Todavia, não se constata qualquer referência à Justiça Militar nessa Constituição.

Com a queda da Monarquia e a instituição da República, a Constituição de 24 de fevereiro de 1891 prescreveu em seu art. $77^{165}$ a existência da Justiça Militar e do Supremo Tribunal Militar, delineando as primeiras competências para esses órgãos, ao especificar que --“os militares de terra e de mar terão foro especial nos delitos militares"166--. Posteriormente, a organização e as atribuições do Supremo Tribunal Militar vieram a ser definidas pela Lei $\mathrm{n}^{\circ} 149$, de 18.7.1893, sendo substituída em 30 de outubro de 1920, quando da criação do Código de Organização Judiciário e Processo Militar, pelo Decreto $\mathrm{n}^{\circ} 14.450$.

Em 1920, portanto, a Justiça Militar foi reorganizada. De acordo com o Código de Organização e Judiciária e Processo Militar daquele ano, o território brasileiro estaria dividido em doze Circunscrições, para administração da Justiça Castrense. As Auditorias Militares passaram a funcionar como primeira instância dessa justiça especializada, tendo o CSJM como instância de recurso ${ }^{167}$.

No âmbito das Auditorias Militares, passaram a funcionar os Conselhos de Justiça Militar, que eram compostos por um auditor e quatro juízes militares, que deveriam ser sorteados entre o oficialato, para servir no Conselho durante seis meses consecutivos, período no qual estariam dispensados do serviço militar.

O CSJM era composto de nove ministros vitalícios, nomeados pelo presidente da República, sendo quatro civis, três do Exército e dois da Armada, deixando clara a proeminência do Exército.

\footnotetext{
${ }^{164}$ Constituição do Império do Brazil- Carta da Lei, de 25 de março de 1824.

Art. 10. Os Poderes Políticos reconhecidos pela Constituição do Império do Brazil são quatro: o Poder Legislativo, o Poder Moderador, o Poder Executivo, e o Poder Judicial.

${ }^{165}$ Constituição da República dos Estados Unidos do Brasil, de 24 de fevereiro de 1891.

Art. 77- Os militares de terra e mar terão foro especial nos delitos militares.

$\S 1^{\circ}$ - Este foro compor-se-á de um Supremo Tribunal Militar, cujos membros serão vitalícios, e dos conselhos necessários para a formação da culpa e julgamento dos crimes.

$\S 2^{\circ}$ - A organização e atribuições do Supremo Tribunal Militar serão reguladas por lei.

${ }^{166}$ Art. $81, \S 3^{\circ}$.

${ }^{167}$ A partir desse Código de Organização Judiciária, o processo passou a se iniciar "com o recebimento da denúncia pelo auditor, efetiva-se com a citação do acusado e se extingue quando a sentença definitiva se torna irrecorrível" (SAMPAIO, Carlos Alberto H. de Oliveira. "Justiça Militar brasileira”, in Revista do Superior Tribunal Militar, Brasília, 1976, s/n, p. 65-81).
} 
A Carta Política de 16 de julho de 1934 incorporou, finalmente, a Justiça Castrense $^{168}$ à estrutura do Poder Judiciário ${ }^{169}$ como decorrência da vontade soberana da Assembleia Nacional Constituinte, angariando a competência para julgar civis nos casos nela expressamente referidos. De se consignar, ainda, que a Constituição de 1934 foi pródiga na regulamentação ${ }^{170}$ da justiça primaz do Brasil.

O Golpe de Estado ocorrido em 10 de novembro de 1937, a seu turno, institucionalizou o chamado 'Estado Novo' no Brasil. Contudo, a Constituição "Polaca"171 outorgada pela ditadura getulista manteria a Justiça Militar integrada ao Poder Judiciário, assegurando-lhe a competência e as regulamentações atribuídas na Constituição anterior $^{172}$. No que se refere à segurança externa, todavia, foi além ao tratar da defesa do Estado, acrescentando a possibilidade de aplicação das penas da legislação militar e da jurisdição dos tribunais militares ${ }^{173}$ nas zonas de operações, durante grave comoção interna $^{174}$.

Ainda, não é despiciendo aclarar que um tribunal exótico, o Tribunal de Segurança Nacional (“TSN"), foi criado por meio da Lei $\mathrm{n}^{\circ}$ 244, de 11 de setembro de 1936, que o instituiu como órgão da Justiça Militar, para julgar os acusados de "crimes

\footnotetext{
${ }^{168}$ O Supremo Tribunal Militar era composto por 11 Ministros, nomeados pelo Presidente da República, sendo 04 dentre os Generais efetivos do Exército, 03 dentre os Generais efetivos da Armada e 04 civis. Dos Ministros togados, 02 eram escolhidos dentre os brasileiros natos de notória competência jurídica e reputação ilibada, com prática forense superior a 10 anos e idade entre 35 e 58 anos. As demais eram ocupadas por um Auditor e pelo Procurador Geral, que deveriam ter mais de 35 anos de idade e pelo menos 06 anos de exercício funcional.

${ }^{169}$ Constituição da República dos Estados Unidos do Brasil, de 16 de julho de 1934.

Art. 63- São órgãos do Poder Judiciário: a) a Corte Suprema; b) os Juízes e Tribunais federais; c) os Juízes e Tribunais militares; d) os Juízes e Tribunais eleitorais.

${ }^{170}$ Como se pode ver no art. 63, alínea c); 76, alínea n) nº3); 78; 81, alínea i); Seção V, Art. 84 a 87; nos arts. 165, $\$ 1^{\circ}$ e $175, \S 4^{\circ}$.

${ }^{171} \mathrm{http}: / /$ www.revistadehistoria.com.br/secao/artigos/a-polaca (acesso em 02.05.2016).

172 Bastando apenas a leitura dos arts. 90, "c" e 111, da Constituição de 1937, para sua compreensão.

${ }^{173}$ Constituição dos Estados Unidos do Brasil, de 10 de novembro de 1937.

Art. 111- Os militares e as pessoas a eles assemelhadas terão foro especial nos delitos militares. Este foro poderá estender-se aos civis, nos casos expressos em lei, para os crimes contra a segurança externa do País, ou contra as instituições militares.

Art. 172- Os crimes cometidos contra a segurança do Estado e a estrutura das instituições serão sujeitos à Justiça e processos especiais, que a lei prescreverá. $§ 1^{\circ}$ A lei poderá determinar a aplicação das penas da legislação militar e jurisdição dos tribunais militares na zona de operações durante grave comoção intestina.

${ }^{174}$ Quando se escreve a respeito da Justiça Militar, não se pode deixar de relacionar a sua existência com os diversos fatos históricos que marcaram a evolução política e social do país, particularmente no que se refere aos julgamentos de militares e civis que participaram de movimentos políticos/insurrecionais/revolucionários, como os abaixo nomeados:

-a Revolta da Chibata, em 1873;

-a $2^{\mathrm{a}}$ Revolta da Armada, em 1893;

- a Revolta dos Dezoito do Forte, no Rio de Janeiro, em 1922;

- a Revolução Constitucionalista de 1932;

- a Intentona Comunista de 1935;

- o levante da Ação Integralista Brasileira, em 1938;

- as Revoltas de Jacareacanga/Aragarças em 1956/1959;

- os diversos fatos políticos pós março de 1963, quando à Justiça Militar foi atribuído o encargo de processar e julgar os crimes tipificados na Lei de Segurança Nacional. (fonte: Coletânea de Estudos Jurídicos. Publicação em comemoração ao Bicentenário da Justiça Militar no Brasil./ Maria Elizabeth Guimarães Teixeira Rocha, Zilah Maria Callado Fadul Petersen, coordenadoras; Samantha Ribeiro Meyer -Pflug, colaboradora.- Brasília: Superior Tribunal Militar, 2008. p.88)
} 
contra a segurança externa do Estado", e "crimes contra as instituições militares", definidos na lei que estabelecia os crimes contra a ordem política e social ${ }^{175}$, estabelecendo, inicialmente, a possibilidade de recursos contra suas decisões ao STM, sem efeito suspensivo $^{176}$.

Nesse período de 1936 a 1937, a Justiça Militar funcionou, por pouco mais de um ano $^{177}$, como auxiliar do processo de punição da ditadura varguista, mas não foi cogitada para assumir o papel de instituição central no processo e julgamento de opositores políticos, ou seja, não atuou diretamente como um tribunal de exceção ${ }^{178}$.

Em 09 de dezembro de 1938, foi instituído o novo Código de Justiça Militar, com o Decreto-Lei n. 925, a fim de atualizar a organização e a regulamentação da Justiça Militar. Veio acompanhado, em 1944, da edição de um novo Código Penal Militar, cujo artífice foi o desembargador Sílvio Martins Teixeira, e que viria a servir de base para a tipificação de todos os delitos julgados pela Justiça Expedicionária Brasileira durante a $2^{\mathrm{a}}$ Guerra Mundial.

Promulgada novel Lei Maior em 1946, esta manteria os preceitos relativos à Justiça Militar estabelecidos pelos dois Textos anteriores (art. 94, III e 108, caput), ficando a competência da Justiça Militar restrita ao julgamento de crimes militares e de civis, nos crimes cometidos contra a segurança externa do país ou às instituições militares, e introduzindo pequena modificação, ao alterar o nome do Supremo Tribunal Militar ${ }^{179}$, existente desde 1891, para Superior Tribunal Militar ${ }^{180}$, mantido ainda hoje.

No regime que se organizou a partir da Constituição democrática de 1946, o TSN foi considerado como "Justiça de Exceção" e sua extinção tornou-se um imperativo, sendo a competência da Justiça Militar, para o julgamento de civis, novamente restrita aos crimes contra a segurança externa e contra as instituições militares.

\footnotetext{
${ }^{175}$ Lei $\mathrm{n}^{\mathrm{o}} 38$, de 04 de abril de 1935.

${ }^{176}$ Histórias de Vida/ Coordenação: Centro de Memória do MPM; organização: Gunter Axt.- Brasília, 2016. pg. 24.

${ }^{177}$ O vínculo do TSN com a Justiça Militar acabou em 20 de dezembro de 1937, com a edição do decreto-lei n. 88, segundo o qual os recursos do TSN seriam julgados por ele mesmo.

${ }^{178}$ Para maiores referências sobre a conexão entre o TSN e o CSJM no período, ver - D’ ARAUJO, Maria Celina S. da. Militares, democracia e desenvolvimento: Brasil e América do Sul. Rio de Janeiro: FGV, 2010.

${ }^{179}$ A comentada alteração se deu mediante proposta do deputado Silvestre Péricles (CARNEIRO, Márcio Tibúrcio Gomes, Estudos de Direito Penal Militar, p. 45), restringindo-se apenas ao Pretório Excelso, o título de Supremo.

${ }^{180}$ A partir de então, a presidência da instituição passou a ser assumida por um dos seus integrantes e não mais por um representante do governo, como era o caso do CSJM, que fora presidido pelo imperador, concedendo certo grau de autonomia à instituição, desvinculando-a, formalmente, da esfera política.
} 
Com o golpe de 1964, o novo regime fez mudanças, pela Carta de 1967, na composição do Superior Tribunal Militar, tais como: a alteração do número de seus membros, a inclusão de representantes do Ministério da Aeronáutica e a ampliação da sua competência:

Tabela 3: Composição do Supremo Tribunal Militar através dos tempos

\begin{tabular}{|c|c|c|c|c|}
\hline \multicolumn{5}{|c|}{ Composição através dos tempos } \\
\hline Nome & Legislação & Membros & Título & \\
\hline $\begin{array}{l}\text { Conselho Supremo } \\
\text { Militar e de Justiça }\end{array}$ & Álvará de 01/04/1808 & 15 & $\begin{array}{c}\text { Conselheiros de Guerra } \\
\text { Conselheiros do Amirantado } \\
\text { Wgais }\end{array}$ & \multirow{4}{*}{$\begin{array}{c}\text { Poder } \\
\text { Executivo }\end{array}$} \\
\hline \multirow{4}{*}{$\begin{array}{l}\text { Supremo Tribunal } \\
\text { Militar }\end{array}$} & $\begin{array}{c}\text { Decreto Legislativo n } \\
149, \text { de } 18 / 09 / 1893\end{array}$ & 15 & \multirow{6}{*}{ Ministros } & \\
\hline & $\begin{array}{c}\text { Decreto } 14450, \text { de } \\
30 / 10 / 1920\end{array}$ & 9 & & \\
\hline & $\begin{array}{c}\text { Decreto } 17231-1 \text {, de } \\
26 / 02 / 1926\end{array}$ & 10 & & \\
\hline & $\begin{array}{l}\text { Constituição de } \\
16 / 07 / 1934\end{array}$ & 11 & & \multirow{3}{*}{$\begin{array}{c}\text { Poder } \\
\text { Judiciário }\end{array}$} \\
\hline \multirow{2}{*}{$\begin{array}{c}\text { Superior Tribunal } \\
\text { Militar }\end{array}$} & $\begin{array}{l}\text { Constituição de } \\
18 / 09 / 1946\end{array}$ & 11 & & \\
\hline & $\begin{array}{l}\text { Ato Institucional } n^{\circ} 2 \text {, } \\
\text { de } 27 / 10 / 1965\end{array}$ & 15 & & \\
\hline
\end{tabular}

Cabe lembrar também que, face ao art. $8^{\circ}$ do Ato Institucional $\mathrm{n}^{\mathrm{o}} 2$, de 27.10.65, a competência da Justiça Militar para julgar civis foi ampliada, compreendendo não só os crimes contra as instituições militares, como também os contra a segurança nacional, açambarcando tanto a externa, quanto à interna ${ }^{181}$.

O diploma político e Carta Constitucional de 1967, bem como a Emenda Constitucional de 1969, mantiveram as normas constitucionais então vigentes em relação à Justiça Castrense, introduzindo a novidade do recurso ordinário ao Supremo Tribunal Federal ("STF”) ${ }^{182}$ contra as decisões proferidas pela Justiça Militar, nos casos previstos em lei, contra civis, Governadores e Secretários de Estado ${ }^{183}$.

\footnotetext{
${ }^{181}$ COSTA, Álvaro Mayrink. Crime Militar.p.30.

182 Constituição da República Federativa do Brasil, de 24 de janeiro de 1967.

Art. 119-Compete ao Supremo Tribunal Federal: (...) II- Julgar em recurso ordinário: (...) b) os casos previstos no art. $129, \S 1^{\circ}$ e $\S 2^{\circ}$.

${ }^{183}$ Art. 129- À Justiça Militar compete processar e julgar, nos crimes militares definidos em lei, os militares e as pessoas que lhe são assemelhadas. $\$ 1^{\circ}$ Esse foro especial estender-se-á aos civis nos casos expressos em lei, para repressão de crimes contra a segurança nacional ou as instituições militares. $\S 2^{\circ}$ Compete originariamente ao Superior Tribunal Militar processar e julgar os Governadores de Estado e seus Secretários nos crimes de que trata o $\S 1^{\circ}$.
} 
O terceiro Código Penal Militar da História do Brasil foi editado em 1969, sob o regime militar que se instaurara em 1964, persistindo em constante vigência até os dias atuais.

Encerrado esse período, a vigente Lei Maior promulgada em 1988 manteve os Tribunais e Juízes Militares como integrantes do Poder Judiciário nacional, deslocando, para a Justiça Federal, a competência para o processo e julgamento dos crimes políticos e a apreciação dos crimes contra a Segurança Nacional, --“excluídas as contravenções e ressalvada a competência da Justiça Militar e da Justiça Eleitoral'--. Contudo, ampliou suas atribuições competência ao remeter o tópico da definição de sua competência para a legislação infraconstitucional ${ }^{184}$, mantendo "in totum" o recurso ao STF. Esse é, em síntese, o resultado da evolução da Justiça Militar brasileira.

\section{(ii) A Justiça Militar no Estado Novo.}

A vitória da Revolução de 30 no Brasil ensejou transformações profundas na estrutura política nacional. O governo provisório revolucionário, chefiado por Getúlio Vargas, dissolveu as câmaras legislativas federais, estaduais e municipais, de maneira a enfeixar tanto o poder executivo como o legislativo.

Excetuando-se o Estado de Minas Gerais, todos os governadores foram destituídos dos seus cargos, tendo sido nomeados interventores, subordinados ao governo central, para governar os Estados ${ }^{185}$.

A partir daí os governos estaduais perderam o poder de contrair empréstimos sem autorização do poder central e tampouco despender recursos significativos com equipamento das Polícias Militares e remuneração de seus efetivos.

A direção política do novo governo era clara ao tomar tais medidas: tratava-se de limitar a autonomia dos Estados, então considerada excessiva pelas forças da revolução ${ }^{186}$.

Ao mesmo tempo em que intervinha na esfera política, o novo governo tratou de concentrar a direção da política econômica nacional, algo que, em parte, atendia às exigências do panorama econômico internacional. Em 1931, foi suspenso o pagamento da

\footnotetext{
${ }^{184}$ Constituição da República Federativa do Brasil, de 05 de outubro de 1988.

Art. 124- À Justiça Militar compete processar e julgar os crimes militares definidos em lei. Parágrafo único. A lei disporá sobre a organização, o funcionamento e a competência da Justiça Militar.

${ }^{185}$ FAUSTO, Boris. História do Brasil. 2 ed. São Paulo: Edusp, 1995.

${ }^{186}$ FAORO, Raymundo. Os donos do poder: formação do patronato político brasileiro. 6. ed. Porto Alegre: Globo, 1984.
} 
dívida externa e o governo assumiu o controle monopolista do câmbio, obrigando os exportadores a trocar a receita em moeda estrangeira por dinheiro brasileiro ${ }^{187}$.

$\mathrm{Na}$ esfera social, a estratégia adotada pelo governo revolucionário consistiu no esforço para ampliar seu apoio junto à classe trabalhadora. Com tal objetivo, reprimiu duramente o Partido Comunista Brasileiro de maneira a subtrair a sua influência junto aos sindicatos, ao mesmo tempo em que estimulou a organização sindical, subordinando-a aos seus desígnios ${ }^{188}$.

Para isso, foi criado o Ministério do Trabalho, Indústria e Comércio em 1930, além de toda uma legislação trabalhista e órgãos destinados a arbitrar o conflito entre empregadores e empregados: as Juntas de Conciliação e Julgamento; regulamentado o trabalho dos menores e das mulheres, o direito a férias remuneradas e a jornada de trabalho de oito horas.

Além disso, atrelaram-se os sindicatos ao governo. Para integral controle sobre os órgãos de representação dos interesses dos trabalhadores, foi adotada a unidade sindical- cada categoria profissional teria apenas um sindicato numa dada base territorial-, além de se exigir o reconhecimento do governo para sua existência legal. Assim, restou extinto todo e qualquer traço de autonomia sindical.

Quanto à natureza do governo revolucionário, pode-se dizer que se tratava de um governo reformista que pretendia assegurar a hegemonia da burguesia liberal conservadora mediante a modernização das estruturas nacionais por intermédio de processos que combinavam práticas do coronelismo com a mobilização das massas trabalhadoras sob o controle da burocracia estatal ${ }^{189}$.

O método utilizado para atingir tais fins consistia na manipulação política e na repressão de qualquer dissidência que pudesse ameaçar tal projeto ${ }^{190}$.

Tais características do regime que a Revolução de 30 inaugurou são explicadas corretamente por Lincoln Penna ${ }^{191}$, segundo o qual o novo regime, instaurado numa sociedade ainda marcada por fortes traços preliminares ao capitalismo que se tinha conhecimento na época, carecia -“(...) de uma representação burguesa capaz de conceber um projeto para o exercício de seu poder e de uma classe operária interpretasse do

\footnotetext{
${ }^{187}$ CORSI, Francisco Luiz. Estado Novo: política externa e projeto nacional. São Paulo: Unesp, 2000.

${ }^{188}$ Idem.

${ }^{189}$ FAORO, p. 4.

${ }^{190}$ LOPEZ, Adriana; MOTA, Carlos Guilherme. História do Brasil: uma interpretação. São Paulo: SENAC, 2008.p. 640.

${ }^{191}$ PENNA, Lincoln de Abre. República brasileira: Nova Fronteira, 1999. p. 188.
} 
mundo do trabalho. A hipertrofia do Estado surge, assim, como decorrência natural desse quadro"--.

Em 14 de julho de 1934, uma nova Constituição política substituiu a de 1891, adequando a estrutura legal do país aos novos tempos. Tratava-se de uma carta constitucional nacionalista e, por outro lado, de tendência social democrata, traduzindo a tendência intervencionista estatal daqueles tempos. Em pouco tempo, uma série de crises políticas propiciariam a instauração de um governo autocrático no país, liderado por Getúlio Vargas ${ }^{192}$.

No ano da promulgação da Constituição de 1934, o país encontrava-se em plena ebulição política. Por um lado, greves operárias se somavam à insatisfação da classe média para pressionar o governo; por outro, ocorria uma radicalização política entre a esquerda, representada, sobretudo, pelo Partido Comunista, e a extrema direita, na qual se encontrava o Partido Integralista, organização fascista tipicamente nacional que apresentava pontos em comum com o fascismo então em evidência no continente europeu.

Tal conjuntura decerto favoreceu a ascensão de forças autoritárias ao poder político, a exemplo das Forças Armadas, interessadas na preservação da ordem imposta ao conjunto da sociedade. A resposta imediata de tais setores às reivindicações sociais consistiu numa Lei de Segurança Nacional promulgada em 04 de abril de 1935 com o objetivo de combater à "subversão" da ordem econômica e social 193 .

Dias antes, mais precisamente em 30 de março de 1935, surgiu a Aliança Libertadora Nacional (“ANL”), organização sob a hegemonia do Partido Comunista Brasileiro, com um programa nacionalista, presidida por Luís Carlos Prestes. Em 11 de julho de 1935, contudo, o governo decretou o encerramento das atividades da referida organização política. Inconformado, em 23 de novembro de 1935, o Partido Comunista tentou, de forma fracassada, derrubar o governo. Na oportunidade, o Congresso Nacional decretou estado de sítio, o qual perduraria até $1937^{194}$.

Em fins de 1936, foi criado o $\mathrm{TSN}^{195}$, como órgão da Justiça Militar, destinado a julgar crimes políticos e contra a segurança do país, que funcionaria com sede $^{196}$ no Distrito Federal até o fim do Estado Novo.

\footnotetext{
192 FAUSTO, p. 95.

${ }^{193}$ CARVALHO, José Murilo de. Forças armadas e política no Brasil. Rio de Janeiro: Jorge Zahar Editora, 2005.

${ }^{194}$ FAORO, p. 198.

${ }^{195}$ Lei $\mathrm{n}^{\circ} 244$, de 11 de setembro de 1936.

${ }^{196}$ Lei Constitucional no 14 , de 17 de novembro de 1945.
} 
Quando de sua criação, o TSN era presidido por um Ministro do Supremo Tribunal Federal e integrado, até 1937, por cinco membros, sendo dois militares. Era, como dito, órgão de $1^{a}$ instância da Justiça Castrense, com competência para processar e julgar crimes contra a segurança externa do país e as instituições militares, --"sempre que decretado o estado de guerra e até que se ultime o processo dos crimes de sua competência"-- ${ }^{197}$, inclusive para os fatos puníveis cometidos anteriormente à data de sua criação, desde que não julgados.

Ademais, o TSN destinava-se a julgar, em primeira instância, militares e civis acusados de "crimes contra a segurança externa da República" e "crimes contra as instituições militares". Os delitos tipicamente militares permaneceram de competência da Justiça Castrense.

Contudo, havia sempre a possibilidade de recurso das decisões do TSN para o STM, em que pese a inexistência de efeito suspensivo ${ }^{198}$, com a necessidade de cumprimento imediato da sentença decretada.

Os insurretos de 1935 (“intentona comunista ${ }^{199 » "), ~ c u j a s ~ c o n d u t a s ~ f o r a m ~}$ consideradas como causadoras de "comoção intestina grave" por suas finalidades subversivas análogas ao estado de guerra, foram todos processados e julgados pelo TSN.

Como bem recorda Maria Celina D’Araújo, -“a insurreição de 1935 fora um levante militar e o governo estava particularmente preocupado em expurgar o Exército de suas vozes dissidentes"--. Tal preocupação da cúpula militar com as facções levou Góis Monteiro a dizer, na ocasião, que -"era preciso acabar com a política no Exército e impor a política do Exército"-- 200.

Em verdade, entre os meses de setembro de 1936 e dezembro de $1937^{201}$, o TSN condenou 1.420 pessoas, sendo a maioria delas residentes no Rio de Janeiro (533); Rio Grande do Norte (222) e São Paulo (165) $)^{202}$.

\footnotetext{
${ }^{197}$ Art. $1^{\circ}$, da lei n. 244, de 11.09.1936.

${ }^{198}$ Histórias de Vida/ Coordenação: Centro de Memória do MPM; organização: Gunter Axt.- Brasília, 2016. p. 24.

$199 \mathrm{http}: / /$ www.sohistoria.com.br/ef2/eravargas/p2.php (acesso em 02.05.2016).

200 FREITAS, p. 201.

${ }^{201}$ A Constituição de 1937, por sinal, admitia a aplicação da pena de morte de civis nas seguintes hipóteses relacionadas em seu artigo 122: (a) tentar submeter o território da Nação ou parte dele à soberania de Estado estrangeiro; (b) tentar, com auxílio ou subsídio de Estado estrangeiro ou organização de caráter internacional, contra a unidade da Nação, procurando desmembrar o território sujeito à sua soberania; (c) tenta por meio de movimento armado o desmembramento do território nacional, desde que para reprimi-lo se torne necessário proceder a operações de guerra; (d) tentar, com auxílio ou subsídio de Estado estrangeiro ou organização de caráter internacional, a mudança da ordem política ou social estabelecida na Constituição; (e) tentar subverter por meios violentos a ordem política e social, com o fim de apoderar-se do Estado para o estabelecimento da ditadura de uma classe social; (f) o homicídio por motivo fútil e com extrema perversidade.

${ }^{202}$ Idem.
} 
Após a decretação do Estado Novo, o TSN tornou-se órgão jurisdicional especial autônomo e permanente, e não mais um órgão da Justiça Militar, passando a ser integrado por um total de seis magistrados, sendo três militares, sob a presidência de um magistrado civil, todos nomeados pelo Presidente da República ${ }^{203}$.

Durante o Estado de Guerra, decretado oficialmente no Brasil a partir de 31 de agosto de 1942, com a vigência do Decreto n 10.358, ainda estava em funcionamento o TSN, que processava e julgava os crimes militares e contra a ordem social e política do país, consoante o processo penal militar regido pelo Código de Justiça e Organização Militar de 1938. Eram tempos autoritários.

Com a edição da Portaria de 09 de agosto de 1943, assinada pelo Ministro Eurico Gaspar Dutra, foi criada a $1^{\text {a }}$ Divisão de Infantaria, deu-se o passo inaugural na estruturação das tropas que seriam enviadas para operações no continente europeu.

Surgiu, assim, a necessidade da instauração de um Tribunal especializado que pudesse julgar as causas de soldados brasileiros, bem como de indivíduos que atentassem contra a segurança da Nação brasileira, em solo estrangeiro.

A seguir, expõe-se de forma detalhada como se deu a criação da Justiça Militar Expedicionária Brasileira, o comissionamento de seus membros e a edição da legislação que amparou toda sua atuação no teatro de guerra da Itália.

\section{(iii) A criação da Justiça Militar Expedicionária.}

Há mais de meio século os integrantes da FEB, escreveram seus nomes na história contemporânea do Brasil. Mais de 25 mil militares do Exército e da Aeronáutica brasileira chegaram à Itália para lutar, ao lado das Forças Aliadas, contra os países que compunham o Eixo (Alemanha, Itália e Japão).

As campanhas de Monte Castelo, Castelnuovo, Montese, Vale do Pó e tantas outras, possíveis com a superação dos combatentes brasileiros que fizeram parte da guerra, também contaram com homens tão determinados quanto os oficiais e praças da FEB. Eram juízes, promotores, advogados e servidores que, usando os uniformes da FEB e uma balança, tendo como fiel uma espada por distintivo ${ }^{204}$, atuaram junto às Forças Expedicionárias Brasileiras, com a missão de processar e julgar os crimes que, porventura, viessem a ser cometido pelos militares no teatro operacional durante a II Guerra Mundial.

\footnotetext{
${ }^{203}$ LOBÃO, Célio. Direito Penal Militar atualizado. Brasília, DF: Brasília Jurídica,1995.

${ }^{204}$ Aviso de 1.649, de 21 de junho de 1944.
} 
Em relação a esses membros que compuseram a Justiça Expedicionária, é necessário esclarecer ter havido o comissionamento de civis que oficiavam perante a Justiça Militar brasileira para atuarem no teatro de guerra europeu.

Naquele momento histórico, o Código de Justiça Militar ${ }^{205}$, ao tratar da inamovibilidade desses membros civis da Justiça Militar brasileira, excepcionava, em seu art. 62, parágrafo único, que dita inamovibilidade não excluiria a obrigação de acompanharem as Forças junto às quais tivessem de servir.

Tratando especificamente da Justiça Militar em tempo de guerra, o art. 377, do Código de Justiça Militar, asseverava que --“os auditores, promotores, advogados e demais funcionários, acompanharão, nas operações de guerra, as unidades que lhe forem designadas, segundo as conveniências do serviço, provendo-se a substituição deles, na sede da auditoria, na forma do art. 54. (...)"---

Com efeito, portanto, a questão da Justiça em tempo de guerra exigiu alterações no sistema vigente, para adequar a legislação específica às contingências do envio de uma Força Expedicionária ao Teatro de operações no além-mar.

Por essa razão, a fim de acompanharem a FEB, criou-se, através da edição de Decreto-Lei ${ }^{206}$, na Reserva da $2^{\mathrm{a}}$ Classe do Exército, um Quadro Especial para os Membros da Justiça Militar da Força Expedicionária Brasileira para atender às peculiaridades da FEB, efetivando-se, assim, o comissionamento de membros da Magistratura, do Ministério Público, da Advocacia e outros servidores (escrivães e oficiais de justiça) em postos militares.

Nesse Quadro Especial, o Ministro Civil do Supremo Tribunal Militar ${ }^{207}$ tinha o posto de General-de-Divisão; o Procurador-Geral, membro do Ministério Público que atuava perante o CSJM, o de General-de-Brigada; os Auditores de $2^{\mathrm{a}}$ e $1^{\mathrm{a}}$ entrância, respectivamente, os de Coronel e Tenente-Coronel; os Promotores de $2^{\mathrm{a}}$ e $1^{\mathrm{a}}$ entrância, respectivamente, os de Major e Capitão; e os Advogados e os Escrivães, o de $2^{\circ}$ Tenente.

Assim, em 28.07.1944, foram inseridos no Quadro Especial de Oficiais da Reserva de $2^{\text {a }}$ Classe, o Ministro do CSJM Washington Vaz de Mello, com o posto de General-de-Divisão; o Procurador-Geral da Justiça Militar, Waldomiro Gomes Ferreira, com o posto de General-de-Brigada; os Juízes- Auditores Adalberto Barreto e Eugênio Carvalho do Nascimento, com o posto de Tenente-Coronel; os Promotores da Justiça

\footnotetext{
${ }^{205}$ Decreto-Lei n ${ }^{\circ}$ 925, de 02.12.1938.

${ }^{206}$ Decreto-Lei n. 6.509, de 18.05.1944, alterado pelo Decreto-Lei n. 6.678, de 13.07.1944.

${ }^{207}$ Atual Superior Tribunal Militar.
} 
Militar Orlando Moutinho Ribeiro da Costa e Amador Cysneiros do Amaral, com o posto de Capitão; os Advogados Raúl da Rocha Martins e Bento Costa Lima Leite de Albuquerque, com os postos $2^{\circ}$ Tenente; o Secretário do CSJM, Iberê Garcindo Fernandes, com o posto de $1^{\circ}$ Tenente e; os Escrivães Ari Abott Romero e Valter Belo Faria, com o posto de $2^{\circ}$ Tenente ${ }^{208}$.

Tal sistema, aparentemente discriminatório aos olhos da sociedade, na medida em que atribuía postos hierarquicamente superiores aos julgadores e acusadores, em oposição à patente rasa delegada aos advogados, pautava-se na legislação vigente à época, como nos recorda Assis ${ }^{209}$.

Não é demais lembrar que, à época, os auditores, defensores e membros do Ministério Público junto à Justiça Militar eram, todos, nomeados pelo Presidente da República $^{210}$, existindo, além daqueles nomeados por concurso, a possibilidade de nomeação de suplentes de auditor e adjuntos de promotor, sem o necessário concurso público $^{211}$, bastando àqueles, bacharéis de direito com mais de quatro anos de prática forense e, a estes, também bacharéis, mais de dois anos de prática forense, todos mediante proposta do então Ministro da Guerra ou da Marinha, ouvido o Supremo Tribunal Militar, ao qual todos ficariam subordinados.

O Procurador-Geral, que chefiava a instituição do Ministério Público Militar, por exemplo, era escolhido entre doutores e bacharéis em direito, com oito anos de prática forense e notório conhecimento jurídico, além de reputação ilibada. Deveria, ainda, ter idade superior a 35 anos e inferior a 58 anos $^{212}$. Podia, contudo, ser nomeado e demitido livremente pelo Presidente da República ${ }^{213}$. Ademais, no terreno das garantias funcionais, poderia perder o cargo, da mesma forma que os demais membros do Ministério Público Militar, mediante sentença judicial ou, em caso de falta grave, por intermédio de procedimento administrativo instaurado pelo Supremo Tribunal Militar.

Dessa forma, portanto, se deu o comissionamento de auditores, membros do Ministério Público e advogados de ofício, em postos de oficiais militares, a fim de acompanharem a FEB na Itália, demonstrando (i) visível discriminação de advogados em favorecimento de Promotores e Magistrados e; (ii) a subordinação de membros do

\footnotetext{
${ }^{208}$ Pelo Decreto de ${ }^{\circ} 16.243 / 44$.

209 Jorge César de Assis; Comissionamento em postos militares de Juízes-Auditores, membros do Ministério

Público Militar e da Defensoria Pública da União, por ocasião do Tempo de Guerra; p.2.

${ }^{210}$ Art. 29, do Decreto-Lei n 925/38.

${ }_{211}$ Arts. 37 e 38, do Decreto-Lei n. 925/38.

212 FREITAS, p. 95.

${ }^{213}$ MAZZILI, Hugo Nigro. Introdução ao Ministério Público. p. 43.
} 
Ministério Público ao judiciário, tornando letra morta a pretensa independência funcional desse órgão acusatório; tudo amparado na legislação vigente.

Tal vínculo de subordinação do Ministério Público Militar para com a Justiça Militar tornava letra morta dispositivo do Código de Justiça e Organização Militar de 1938 que repetia a regra prevista no Decreto n 14.450, de 30 de outubro de 1920 que previa, no tocante ao exercício funcional, a independência recíproca entre os órgãos do Ministério Público e os do Judiciário Militar.

Esse fato, era de certa forma, preocupante, pois nos termos da legislação penal militar de 1938, o Ministério Público Militar era o titular absoluto da ação penal. Na ordem jurídica militar, nos termos do artigo 187, não só a ação penal poderia ser promovida apenas pelo Ministério Público Militar, como também previa ao Parquet Castrense a proeminência de incorporar a persecutio criminis, cabendo-lhe, pois, a excelência do manejo da ação penal militar.

Nada obstante, em cada um dos processos julgados, incumbia a esses membros comissionados, ademais de tutelar o bem jurídico violado no caso específico, o auxílio na preservação da hierarquia e disciplina da FEB, em uma situação extrema como a guerra, quando os homens têm suas virtudes e fraquezas colocadas à prova.

Atuaram perante uma Justiça Expedicionária que restou organizada e regularizada pelo Decreto-Lei $n^{\circ}$ 6.396, datado de $1^{\circ}$ de abril de 1944 (Anexo n. 3), assinado pelo então presidente da República, Getúlio Vargas. A nova legislação continha normas relativas à estrutura dos órgãos judiciários e suas competências, além daquelas relativas à instrução dos processos e recursos.

Nessa senda, o decreto em questão regulou o processo penal militar que deveria ter curso no âmbito da beligerância, contemplando os procedimentos que deveriam ser seguidos, as normas relativas à instrução criminal, bem como os recursos passíveis de manejo.

Assim, embora estivesse em franca vigência o Código de Justiça Militar instituído pelo Decreto-Lei ${ }^{\circ}$ 925, de 02 de dezembro de 1938, que previa a organização e funcionamento da Justiça Militar em tempo de guerra, o Presidente da República houve por bem editar o Decreto-Lei $n^{\circ}$ 6.396, que passou, então, a reger o processo penal ante os órgãos da Justiça Militar instalada no teatro de operações da Itália.

No que diz respeito ao direito material, o Decreto-Lei $n^{\circ} 6.227$, de 24 de janeiro de 1944, promulgou o Código Penal Militar de 1944, que viria a ser utilizado nos julgamentos ocorridos no teatro de Guerra da Itália e disciplinava em sua parte especial, os 
crimes cometidos em tempo de paz e os praticados em tempo de guerra; restringindo a estes a sentença à pena de morte, executada por meio de fuzilamento.

Convém assinalar que toda a legislação pertinente à Justiça Militar da FEB se resume a seis Decretos-Leis ${ }^{214}$, um Decreto ${ }^{215}$, um Regimento ${ }^{216}$ e um Aviso Ministerial $^{217}$, dos quais, excetuados um Decreto-Lei ${ }^{218}$ e um Decreto ${ }^{219}$, referentes à dissolução da Justiça da FEB e ao indulto presidencial, expedidos em 1945, todos remetem ao ano de 1944.

Nesse contexto, a Justiça Militar Expedicionária, competente para o processo e julgamento dos crimes praticados em zonas de operações militares ou em território estrangeiro, militarmente ocupado por forças brasileiras ${ }^{220}$, se organizou consoante a seguinte divisão ${ }^{221}$ :

(I) o Conselho Supremo de Justiça Militar ${ }^{222}$, competente $^{223}$ para processar e julgar, originariamente, os oficiais generais;

(II) os Conselhos de Justiça ${ }^{224}$, constituídos especificamente para cada processo e competente ${ }^{225}$ para decidir sobre o arquivamento ou a instauração de processos, bem como julgar oficiais, até o posto de Coronel, inclusive;

(III) as Auditorias ${ }^{226}$, competentes ${ }^{227}$ para presidirem a instrução e julgarem os processos das praças, civis e oficiais até o posto de Tenente-Coronel.

Toda a Justiça Militar funcionou inicialmente na Itália, ficando o Conselho Supremo de Justiça sediado em Nápoles. Este representava a segunda instância da Justiça Expedicionária, funcionou naquela cidade de julho a dezembro de 1944, instalando-se em

\footnotetext{
${ }^{214}$ Decreto-Lei $\mathrm{n}^{\circ}$ 6.396, de $1^{\circ}$ de Abril de 1944; Decreto-Lei $\mathrm{n}^{\circ}$ 6.509, de 18 de maio de 1944; Decreto- Lei $\mathrm{n}^{\circ}$ 6.595, de 16 de junho de 1944; Decreto-Lei ${ }^{\circ}$ 6.678, de 13 de julho de 1944; Decreto-Lei $n^{\circ} 7.507$, de 20 de novembro de 1944; Decreto-Lei n ${ }^{\circ} 8.443$, de 26 de dezembro de 1945.

${ }^{215}$ Decreto $^{\circ} 20.082$, de 03 de dezembro de 1945 .

${ }^{216}$ Regimento Interno do Conselho Supremo de Justiça Militar, de 06 de junho de 1944.

${ }^{217}$ Aviso $^{\circ} 1.649$, de 21 de junho de 1944.

${ }^{218}$ Decreto-Lei no 8.443 , de 26 de dezembro de 1945.

${ }^{219}$ Decreto $^{\circ} 20.082$, de 03 de dezembro de 1945.

${ }^{220}$ Art. $2^{\circ}$, do Decreto-Lei ${ }^{\circ} 6.396$, de $1^{\circ}$ de Abril de 1944.

${ }^{221}$ Decreto-Lei n. 6.396, de 01.04.1944.

${ }^{222}$ Composto por dois oficiais generais, um magistrado militar de carreira, um procurador geral e um advogado de ofício, segundo a redação dos Arts. $3^{\circ}$ e $4^{\circ}$ do Decreto-Lei n ${ }^{\circ} 6.396$, de $1^{\circ}$ de Abril de 1944.

${ }^{223}$ Art.10, I, do Decreto-Lei n ${ }^{\circ} 6.396$, de $1^{\circ}$ de Abril de 1944.

${ }^{224}$ Compostos por um juiz militar de carreira e dois oficiais nomeados pelo Comandante da Divisão, de patente superior ou igual à do acusado, segundo a redação do Art. $6^{\circ}$ do Decreto-Lei n 6.396 , de $1^{\circ}$ de Abril de 1944.

${ }_{225}$ Art. $9^{\circ}$, I e II, do Decreto-Lei $n^{\circ} 7.057$ de 20 de novembro de 1944.

${ }^{226}$ Art. $7^{\circ}$ do Decreto-Lei $n^{\circ}$ 6.396, de $1^{\circ}$ de Abril de 1944, dispunha que haveria uma Auditoria em cada divisão da FEB, composta por um juiz auditor, um promotor, um advogado de ofício, um escrivão e escreventes.
} 
palacete na Via Posillipo, ${ }^{\circ}$ 66, Vialle Costa. Perante esta última instância, atuava pelo Ministério Público Militar, o Procurador-Geral, a quem competia, privativamente, intentar ações penais contra Oficiais-Generais e Coronéis que praticassem crimes militares, bem como emitir pareceres nos recursos interpostos contra as decisões de primeira instância.

O Ministro da Guerra, General Dutra, em viagem de inspeção à Itália, concluiu que não era necessário o CSJM permanecer naquela cidade, já que havia facilidade de comunicação entre o Brasil e o Teatro de Operações. Certamente o Ministro também foi levado a tomar essa decisão ao constatar certa desproporção no quadro da Justiça Militar, que contava com quatro generais para julgar delitos praticados por um efetivo que não excedia de uma Divisão, quando em todo o Teatro de Operações a Justiça Militar americana era supervisionada por apenas um general.

Transferida a sua sede para o Rio de Janeiro pelo Decreto-Lei $\mathrm{n}^{\circ}$ 7057, de 20 de setembro de 1944, o CSJM funcionou, na então capital do Brasil, nas dependências da Escola de Educação Física do Exército, na Fortaleza de São João, na Urca.

Em relação às Auditorias Expedicionárias, divididas em duas, estas se deslocaram constantemente a fim de realizar diligências e instruções de processos para melhor atender às necessidades de apuração dos casos de julgamento, e tomar conhecimento in loco dos acontecimentos relacionados com o processo ${ }^{228}$, muitas vezes em unidades que estavam na frente de combate. Funcionaram, durante o período de hostilidades bélicas, a todo o tempo na Itália, tendo tido como sedes fixas naquele país as cidades de Bagnoli, Vada, San Rossore, Pistóia e Pavana. No Brasil, o Rio de Janeiro foi sede das Auditorias quando o efetivo da FEB retornou.

\section{DA ATUAÇÃo DA JUSTIÇA EXPEDICIONÁRIA NO TEATRO OPERACIONAL DA ITÁLIA (1944/1945)}

\section{(i) Da organização da Justiça Castrense no teatro de operações.}

A fim de melhor expor a forma como se deu a organização ${ }^{229}$ da Justiça Militar Expedicionária Brasileira, convém apresentar as peculiaridades de cada um dos órgãos que compuseram essa Justiça Especializada:

\footnotetext{
${ }^{227}$ Art. $8^{\circ}$ do Decreto-Lei $n^{\circ} 7.057$ de 20 de novembro de 1944.

${ }^{228}$ CASTELO BRANCO, M.T. O Brasil na II Grande Guerra. Rio de Janeiro, Biblioteca do Exército. p. 338.

${ }^{229}$ O Conselho Supremo de Justiça Militar foi integrado pelos seguintes membros: Presidente: General de Divisão Boanerges Lopes de Souza- substituído em julho de 1945 quando transferido para a reserva pelo General de Divisão
} 


\title{
CONSELHO SUPREMO DE JUSTIÇA MILITAR ${ }^{230}$ (“CSJM")
}

\author{
Composição (todos nomeados pelo presidente da República):
}

\author{
- Presidente do CSJM: General de Divisão Boanerges Lopes de Souza \\ - Membro: General de Brigada Francisco de Paula Cidade \\ - Ministro do STM: General de Divisão R2 Washington Vaz de Mello 231 \\ - Procurador-Geral: General de Brigada R2 Waldemiro Gomes Ferreira ${ }^{232}$
}

Heitor Augusto Borges, General de Brigada Francisco de Paula Cidade, General de Divisão Washington Vaz de Melo e
o General de Brigada e Procurador-Geral Waldomiro Gomes Ferreira.
A $1^{\mathrm{a}}$ Auditoria da $1^{\mathrm{a}}$ Divisão de Infantaria Expedicionária tinha os seguintes magistrados: Tenente-Coronel Adalberto
Barreto (Juiz-Auditor), Capitão Orlando Moutinho Ribeiro da Costa (Promotor) e o $2^{\circ}$ Tenente Raul da Rocha Martins
(Advogado de Ofício).
A $2^{\mathrm{a}}$ Auditoria da $1^{\mathrm{a}}$ Divisão de Infantaria Expedicionária tinha como integrantes: Tenente-Coronel Eugênio Carvalho do
Nascimento (Juiz-Auditor), Capitão Amador Cysneiros do Amaral (Promotor) e $2^{\circ}$ Tenente Bento Costa Lima Leite de
Albuquerque (Advogado). Um mês após seu deslocamento ao front, o Promotor da Justiça Militar junto à $2^{\mathrm{a}}$ Auditoria retornou ao Brasil, sendo substituído por Orlando Moutinho Ribeiro da Costa.

${ }^{230}$ Arts. $3^{\circ}, 4^{\circ}$ e $5^{\circ}$ do Decreto ${ }^{\circ} 6.396 / 44$.

${ }^{231}$ Washington Vaz de Mello, Ministro do Supremo Tribunal Militar. Mineiro, nascido em Viçosa em 11 de setembro de 1895, era filho de Carlos Vaz de Mello e D. Maria Augusta Vaz de Mello.

Seu pai fora deputado federal por Minas Gerais, nos períodos de 181 a 1885 e 1894 a 1903 . Ocupou a presidência da Câmara dos Deputados, de 1899 a 1903, e exerceu o mandato de senador, de 1903 a 1904, ano em que faleceu.

Bacharelou-se pela Faculdade de Direito no Rio de Janeiro, então Distrito Federal, em 1919.

Em dezembro de 1920, foi nomeado promotor da então $11^{\text {a }}$ Circunscrição Judiciária Militar, no Rio Grande do Sul, onde atuou até novembro de 1922, quando se tornou consultor jurídico do então ministro da Guerra, o General de Divisão Fernando Setembrino de Carvalho. Em fevereiro de 1924, ocupou o cargo de curador de órfãos do Distrito Federal. A partir de abril de 1926 tornou-se Procurador-Geral da Justiça Militar, cargo que ocupou até o ano de 1940 (a mais longa gestão à frente do Ministério Público Militar até hoje).

Atuou como promotor na ação penal instaurada contra os envolvidos no levante comunista da Aliança Nacional Libertadora (“ANL”), em novembro de 1935, chefiada pelo ex- capitão Luís Carlos Prestes.

Em fevereiro de 1941 foi nomeado Ministro do Superior Tribunal Militar e, como tal, integrava o CJSM junto à FEB, tendo participado também da Comissão que elaborou o anteprojeto que criou aquela Justiça Militar especial (DecretoLei n. 6.396/44). Recebeu elogios por sua destacada atuação e foi designado para representar o Exército Brasileiro na Conferência sobre Direito Militar realizada em Chicago, Estado de Illinois, nos Estados Unidos da América.

Exerceu a vice-presidência do Superior Tribunal Militar de 1960 a 1964. Em 1965 assumiu a presidência de tal pretório e tornou-se o único ministro togado a ocupar esse cargo até a data de hoje. Aposentou-se em agosto de 1965, por ter alcançado o limite de idade.

Casou-se com D. Dorotildes Adam Vaz de Mello, com quem teve dois filhos.

Integrou a Comissão Redatora do Código de Justiça Militar, aprovado em dezembro de 1938. Em 1944, participou da comissão encarregada de elaborar o Código Penal Militar. Foi membro da comissão que elaborou os códigos de Organização Judiciária Militar e de Processo Penal Militar, editados, em 1969, pela junta militar que substituiu o presidente da República Marechal Artur da Costa e Silva, quando de seu afastamento, por motivo de enfermidade. Membro efetivo do prestigioso Instituto dos Advogados do Brasil (IAB), a mais alta academia de letras jurídicas da América Latina, desde 1932. Recebeu a patente de general de divisão do quadro especial da Justiça Militar. Faleceu em 23 de dezembro de 1987. (Fonte: Procuradores-Gerais de Justiça Militar 1920-2016/ Centro de Memória do MPM.Brasília, 2016. Pgs 28/31).

${ }^{232}$ Waldomiro Gomes Ferreira, Procurador-Geral da Justiça Militar de 1941 a 1953, que acompanhou a FEB durante a campanha italiana. Mineiro, nascido em Queluz/MG- atualmente, Conselheiro Lafayette- em 18 de novembro de 1891, filho de João Gomes Ferreira e de D. Amélia Zebral Gomes. Bacharelou-se em Ciências Jurídicas e Sociais pela Faculdade de Direito, exerceu o cargo de delegado de Polícia no município de Viçosa, também em Minas Gerais.

De 1918 a 1922, serviu como oficial de gabinete do governador do Estado de Minas Gerais, o futuro presidente da República Artur Bernardes. 
- Advogado: $2^{\circ}$ Tenente R2 Bento de Costa Lima Albuquerque

- Secretário: $1^{\circ}$ Tenente R2 Iberé Garcindo Fernandes de Sá.

O Conselho Supremo de Justiça Militar da Força Expedicionária Brasileira, órgão judiciário de $2^{\mathrm{a}}$ instância, era integrado por dois Oficiais Generais, da ativa ou da reserva, além de um Juiz militar de carreira, egresso, preferencialmente, do Supremo Tribunal Militar, o qual seria nomeado pelo Presidente da República.

Por sua vez, o Ministério Público Militar funcionava perante o CSJM por intermédio de um Procurador-Geral, Waldomiro Gomes Ferreira, nomeado pelo Presidente da República, que atuava tanto na qualidade de fiscal da lei, opinando nas apelações interpostas contra as decisões de $1^{\mathrm{a}}$ instância, quanto na condição de parte, quando deduzia a pretensão acusatória nos processos de competência originária daquele órgão de $2^{\mathrm{a}}$ instância (oficiais generais).

As funções do CSJM eram, originariamente, as de processar e julgar, privativamente, Oficiais Generais e Coronéis; para examinar e decidir as apelações das sentenças de $1^{\mathrm{a}}$ instância e; para apreciar os embargos interpostos de decisões nos processos de sua competência originária, os quais se prestavam a aclarar algum ponto controverso da decisão. Ainda, era sua competência proferir decisão final nos processos em que o promotor não oferecesse denúncia, ou caso a denúncia fosse rejeitada.

Antes de embarcar à Itália, o Conselho Supremo da Justiça Militar realizou duas sessões em território brasileiro, nas quais aprovou o seu regimento interno. Em julho de 1944 transferiu-se a Nápoles, tendo permanecido em território italiano até dezembro do mesmo ano (a última sessão realizada é de 19 de dezembro de 1944), tendo julgado 121 apelações nesse período, quando teve a sua sede transferida novamente ao Brasil.

Em 20 de novembro de 1944, o Decreto-Lei n. 7.057 (Anexo. n. 6) determinou a transferência de sua sede para o Rio de Janeiro (então capital federal) -- onde passou a funcionar nas dependências da Escola de Educação Física do Exército, na Fortaleza de

\footnotetext{
Em Decreto de 27 de março de 1926, foi nomeado subprocurador-geral da Justiça Militar. Atuou como consultor do Ministério da Guerra, perante os gabinetes dos generais de divisão Góis Monteiro e João Gomes Monteiro, titulares daquela Pasta. No ano de 1936, serviu na Auditoria de Correição, na qualidade de representante do Ministério Público. Foi, tal qual o Juiz militar de carreira que oficiava no CJSM, um dos integrantes da Comissão de juristas incumbida de elaborar o anteprojeto do Decreto-Lei n ${ }^{\circ}$ 6.396/1944, que instituiu a Justiça Militar da Força Expedicionária Brasileira (FEB).

Acompanhou a decantada FEB ao teatro de operações da Itália e foi incluído no Quadro Especial de Oficiais da Reserva de $2^{\text {a }}$ Classe, criado pelo Decreto-Lei n. 6.678, de 13 de julho do mesmo ano, no posto de general de brigada. No interregno em que exerceu suas funções junto ao CSJM, substituiu-lhe como Procurador-Geral interino Fernando Moreira Guimarães (de julho de 1944 a dezembro de 1945) (Fonte: Procuradores-Gerais de Justiça Militar 19202016/ Centro de Memória do MPM.- Brasília, 2016. p. 32 e 34).
} 
São João, na Urca-- sob o argumento, constante da sua exposição de motivos, de que -“as condições especiais que revestem atualmente as operações em que estão empenhadas as Forças Expedicionárias Brasileiras, não exigem o acompanhamento das tropas pelos tribunais de segunda instância"--.

Com o retorno ao Brasil, parcela dos poderes do CSJM, porém, foi transferida aos Auditores e aos Conselhos de Justiça pelo referido Decreto-Lei.

Os Conselhos de Justiça ampliaram sua competência, podendo julgar Coronéis e não apenas Tenentes-Coronéis. Além disso, passaram a ter competência para arquivar inquéritos policial-militares e para instaurar ação penal nos casos de violência contra o inferior, para compeli-lo ao cumprimento do dever legal, ou em repulsa à agressão.

No tocante aos Auditores, foi estendida a sua competência para presidir, monocraticamente, a instrução criminal dos processos com denunciados Coronéis, o que redundou em um problema jurídico: como ele poderia presidir a instrução e julgar Coronéis se estavam comissionados no posto de Tenente-Coronel? Felizmente, considerando-se que nenhum Coronel foi submetido a processo criminal na vigência do referido Decreto-Lei, tal problema jurídico não teve repercussão prática.

Merece registro o expresso reconhecimento ao trabalho e ao saber jurídico do Magistrado Civil que atuava perante o CSJM, Washington Vaz de Mello, e do ProcuradorGeral, Waldemiro Gomes Ferreira, por parte do General de Brigada Francisco de Paula Cidade, um dos integrantes daquela instância recursal na Itália. Em artigo ${ }^{233}$ publicado no Jornal do comércio do Rio de Janeiro em 29 de junho de 1947, o oficial descreveu desta maneira a sua experiência na mais alta corte de justiça da FEB:

“(...) Enfim, integrado no mais alto órgão da justiça militar brasileira em campanha, situação por mim nem sequer imaginada, busquei desempenhar, do melhor modo possível, as delicadas funções que me cabiam. Não queria, de qualquer maneira, sacrificar a modesta reputação adquirida em muitos anos de serviço. O bom senso logo me indicou que, mais que os livros, os dois togados, Washington Vaz de Melo e Waldemiro Gomes Ferreira, muito me podiam auxiliar nos estudos que ia empreender. Efetivamente, devo a esses dois juristas ter apreendido, em pouco tempo, alguma coisa de técnica processual. Dono qualquer deles de vasta cultura profissional, senhor qualquer deles de todas as praxes, mestres ambos na técnica dos tribunais, tive-os sempre solícitos, mesmo quando discordávamos, para que esclarecessem sobre os pontos doutrinários, que me pudessem embaraçar nas questões de direito puro. O resto, procurei sempre fazer por mim mesmo. Num exame de consciência, que me deixa orgulhoso do papel que desempenhei nessa quadra de minha agitada vida de soldado, rendo graças a Deus pelo que me permitiu fazer de bom. E da sua

\footnotetext{
${ }^{233}$ CIDADE, Francisco de Paula. A Justiça Militar na FEB. Do Diário de Um Expedicionário. Rio de Janeiro: Nação
} Armada, 1945. p. 197 e 244. 
infinita misericórdia espero o perdão dos erros que involuntariamente tenha cometido, ao apreciar os delitos ou as fraquezas de meus semelhantes."

Em junho de 1945, por decreto publicado no Diário Oficial do dia 25 daquele mês, foi concedida transferência para reserva do Presidente do CSJM, General de Divisão Boanerges Lopes de Souza. Para sua vaga foi nomeado, através de decreto publicado no D.O.U. em 17 de julho de 1945, o General de Divisão Heitor Augusto Borges que, por força da lei, assumiu a presidência do CSJM até a dissolução da Justiça Militar da Força Expedicionária Brasileira.

Funcionou, ainda, como Magistrado Civil no CSJM, substituindo o General de Divisão Washington Vaz de Mello, quando de sua ausência do Conselho para realizar viagem aos Estados Unidos, a fim de representar o Brasil no Congresso de Direito Militar realizado em Chicago, o Juiz Auditor da $2^{\mathrm{a}}$ Auditoria da $1^{\mathrm{a}}$ DIE, Tenente Coronel Eugênio Carvalho do Nascimento, convocado pela Portaria de 08 de março de 1945.

$\mathrm{Na}$ qualidade de ajudantes de ordens e oficiais à disposição dos membros do Conselho Supremo, serviram ao órgão de $2^{\text {a }}$ instância da Justiça Militar da FEB ${ }^{234}$ :

(i) Na Itália, os oficiais: Capitão José Carneiro de Oliveira; o $1^{\circ}$ Tenente Luiz Wilson Marques de Souza; o $1^{\circ}$ Tenente R2 Amilcar da Costa Rubim e o $2^{\circ}$ Tenente R2 Gerardo Magela Machado. As pracas: $2^{\circ}$ Sargento Vinicio Gomes de Aguiar; os $3^{\circ}$ Sargentos Amaury Tavares Sotero de Farias e Emido Perim; o Cabo José Macedo do Nascimento e os Soldados Quintino dos Santos Cardoso, Cristiano Pereira Duarte, Tolentino Andrade de Camargo e Adalberto Alves Pinho, este último como motorista dos Generais do Conselho. Os civis italianos, como contratados: Maresca Archangelo (cozinheiro); Maelia Risaliti (copeira); Carmine Paesano (servente); Afonso Paesano (jardineiro); Antonio Gemito (cozinheiro); Alberto Gemito (ajudante de cozinheiro); Maria Barbato (copeira arrumadeira); Salvatore Nuccio (motorista); Rosa Esposito (camareira); Rafaela Boreli (copeira) e; Nuccio Santa (ajudante de cozinheiro).

(ii) No Brasil, os oficiais: Capitães Edgard Leite Borges e Antônio Joaquim Correia da Cosa, o primeiro como ajudante de ordens do $2^{\circ}$ Presidente do

\footnotetext{
${ }^{234}$ FREITAS, Ricardo. Memória histórica do Ministério Público Militar.- Brasília: MPM, 2012.
} 
Conselho e o último substituindo o Capitão Carneiro, nomeado para outra comissão. As praças: $3^{\circ}$ Sargento Osmar Campos Filho; o Cabo Edno Alexandre Haddad e; os Soldados Oliver Froes da Cruz, Firmino Formalo, Teodoro Kospizak e Percilio Ferreira. Os civis brasileiros: os civis Brasil Bastos e João Jacy Tome (auxiliares de secretaria).

\section{CONSELHOS DE JUSTIÇA MILITAR ${ }^{235}$}

Os Conselhos de Justiça Militar, diferentemente do CSJM e das Auditorias, não possuíam um corpo permanente, sendo criados à medida que os casos se apresentassem. Quando instituídos, eram compostos por (i) um Auditor e (ii) dois oficiais (nomeados pelo Comandante da Divisão), cuja atuação se limitava ao julgamento de oficiais até o posto de coronel, inclusive.

Competia ao Conselho da Justiça Militar, conforme artigo $9^{\circ}$ do Decreto-Lei $\mathrm{n}^{\mathrm{o}} 7057$--"decidir sobre o arquivamento dos autos de inquérito, se o fato estiver justificado, ou sobre a instauração do processo; na hipótese contrária, nos casos de violência praticada contra inferior para compeli-lo ao cumprimento do dever legal, ou em repulsa a agressão"--.

\section{AUDITORIAIS DE JUSTIÇA MILITAR ${ }^{236}$}

\section{Auditorias:}

Integrantes (Designados pelo Ministro da Guerra entre o pessoal efetivo ou substituto do quadro da Justiça Militar):

- Um auditor (tenente-coronel).

- Um promotor (capitão).

-Um advogado de ofício (segundo tenente).

-Um escrivão (segundo tenente).

Ao auditor competia presidir a instrução criminal dos processos em que fossem réus praças, civis, ou oficiais, até o posto de coronel; julgar as praças e os civis.

\footnotetext{
${ }^{235}$ Art. $6^{\circ}$ do Decreto ${ }^{\circ} 6.396 / 44$.

${ }^{236}$ Art. $7, \S^{\circ}$ do Decreto ${ }^{\circ} 6.396 / 44$.
} 
Atribuiu-se exclusivamente aos auditores, portanto, as funções de juiz instrutor dos processos em todos os casos de oficiais, praças e civis, e de juiz singular, para o julgamento das praças e civis.

A despeito da enorme responsabilidade designada às Auditorias, houve uma atenuação com a instituição da lei de guerra que estabelecia expressamente que, em todos os casos de condenação era obrigatório o recurso à Instância Superior, CSJM ${ }^{237}$.

Funcionaram, no teatro de operações da Itália, duas auditorias, consoante a seguinte divisão:

\section{- $\underline{1^{\mathrm{a}} \text { Auditoria da } 1^{\mathrm{a}} \text { Divisão de Infantaria Expedicionária }}$}

Composição $1^{\mathrm{a}}$ Auditoria da $1^{\mathrm{a}} \mathrm{DIE}$ (fonte. A Feb pelo seu comandante. Pg. 289):

- Juiz-Auditor: Ten Cel Dr Adabelto Tinoco Barreto

- Promotor: Cap Dr Orlando Moutinho Ribeiro da Costa

- Advogado: Ten Dr Raul da Rocha Martins

- Escrivão: Ten Dr Ary Abbott Romero

Constituída por Portaria publicada no dia 26 de maio de 1944 no D.O.U.

Os oficiais componentes da $1^{\mathrm{a}}$ Auditoria da $1^{\mathrm{a}}$ DIE deixaram o Rio de Janeiro, com destino ao Teatro de Operações, em 12 de julho de 1944, chegando a Natal no mesmo dia. Por via aérea, seguiram em direção ao "front" italiano, alcançado Nápoles no dia 20 de julho daquele ano.

O regresso ao Brasil se deu em julho de 1945. Por via aérea retornou o Ten Cel Dr. Adalberto Tinoco Barreto e por via marítima os Ten Dr. Raul da Rocha Martins e Ten Dr. Ary Abbott Romero, embarcando em Nápoles no transporte norte-americano “Gen Meiggs" a 06 de julho e chegando ao Rio de Janeiro a 18 do mesmo mês.

Permaneceu na Itália com a $2^{\mathrm{a}}$ Auditoria o Cap Dr. Orlando Ribeiro da Costa, que acumulava as funções de representante do Ministério Público junto às duas Auditorias

\footnotetext{
${ }^{237}$ Decreto-Lei ${ }^{\circ}$ 6.396/44.

Art. 30- O Promotor apelará, obrigatoriamente:

I- da sentença de absolvição, se a lei cominar para o crime, no máximo, pena privativa de liberdade por tempo superior a seis anos;

II- quando se tratar de crime que a lei comine pena de morte e a sentença for absolutória, ou não aplicar a pena ao máximo.

Art. 31- O advogado de ofício apelará, obrigatoriamente, das sentenças condenatórias.
} 
da FEB, sendo, por isso, o membro da Justiça Militar que mais tempo permaneceu ausente da Pátria em serviço de guerra ${ }^{238}$.

O escrevente da $1^{\text {a }}$ Auditoria era o $3^{\circ}$ Sgt. Wander Soares, responsável pela eficiência dos serviços do Cartório dirigido pelo Ten Ary Abbott Romero.

Como oficial de justiça da $1^{\mathrm{a}}$ Auditoria funcionou o cabo Darcy Pinheiro Carra, promovido a $3^{\circ} \mathrm{Sgt}$ no final da Campanha na Itália. A ele incumbia a realização das intimações dos investigados e denunciados.

O ordenança do Ten Cel Dr. Adalberto Tinoco Barreto, responsável por atender a todos os seus pleitos e solicitações, era o Sd Batistini do efetivo da Cia do QG da $1^{\mathrm{a}}$ DIE.

\section{- $\underline{2^{\mathrm{a}} \text { Auditoria da } 1^{\mathrm{a}} \text { Divisão de Infantaria Expedicionária }}$}

Composição $2^{\mathrm{a}}$ Auditoria da $1^{\mathrm{a}} \mathrm{DIE}$ :

- Juiz-Auditor: Ten Cel Dr Eugênio de Carvalho do Nascimento

- Promotor: Cap Dr Orlando Moutinho Rebeiro da Costa/

Cap R/2 Amador Cisneiros do Amaral

- Advogado: Ten Dr Bento da Costa Lima Leite de Albuquerque

- Escrivão: Ten Dr Walter Bello Faria

Constituída por Portaria de 12 de julho de 1944, seus oficiais foram incluídos no Quadro Especial de Oficiais da Reserva de $2^{\mathrm{a}}$ classe do Exército, pelo Decreto $\mathrm{n}^{\mathrm{o}}$ 16243, publicado no Diário Oficial de 31 de julho de 1944, e convocados para o serviço ativo do Exército pela Portaria n ${ }^{\circ}$ 6977, publicada no D.O.U de 03 agosto 1944.

A $2^{\text {a }}$ Auditoria seguiu para a Itália em 22 de setembro de 1944, a bordo do navio Transporte de Guerra Norte-Americano Gen. 'W.A.MANN', chegando ao porto de Nápoles a 06 de outubro de 1944. Embarcou de regresso no dia 04 setembro de 1945, no transporte Gen. 'MEIGS', desembarcando no Rio de Janeiro a 17 do mesmo mês e ano.

A partir de 15 de fevereiro de 1945, assumiu o exercício do cargo de Auditor da $2^{\text {a }}$ Auditoria o Ten. Cel. Dr. Adalberto Barreto, por motivo de viagem ao Brasil do Ten. Cel. Dr. Eugênio Carvalho do Nascimento, que só veio a reassumir seu posto em 26 de abril de 1945.

\footnotetext{
${ }^{238}$ FREITAS, p. 50.
} 
O Cap. Dr. Orlando Moutinho Ribeiro da Costa foi, praticamente, o Promotor das duas Auditorias da FEB. Da $2^{\mathrm{a}}$ Auditoria foi afastado o promotor Amador Cysneiros do Amaral, que chegou a ir à Itália, sendo evacuado para o Brasil com pouco mais de mês de campanha. Seu substituto foi o Cap. Dr. Clóvis Bevilacqua Sobrinho, que não chegou, contudo, a seguir para o front, entrando em exercício a 26 de outubro de 1945 e funcionando até a dissolução da Justiça Militar Expedicionária, no Brasil.

Como escreventes serviram à $2^{\mathrm{a}}$ Auditoria os Sargentos Vinicio, Hilário e Acioly e o Oficial de Justiça da $2^{\text {a }}$ Auditoria era o Soldado Joselito de Menezes ${ }^{239}$.

\section{(ii) Dos procedimentos processuais adotados pela Justiça Militar Expedicionária.}

O processamento das ações penais era bastante célere. Toda a marcha processual estava definida em um único instrumento legal: Decreto no 6.396/1944 (Anexo n. 3), o que facilitava e simplificava, sobremaneira, a consulta dos operadores do direito à escorreita tramitação processual.

Em apertada síntese, a partir da notícia ou ciência de um crime, fosse ela recebida através da Polícia Militar, dos carabineiros, ou mesmo de um civil ou militar, era aberto um Inquérito, que consistia num caderno investigativo, a fim de proceder com verificações e confirmações das suspeitas de crimes que teriam sido levadas ao conhecimento da Justiça Militar.

Normalmente, nesse primeiro momento, a notícia de um crime era levada ao conhecimento do Auditor mais antigo, com o posto de Tenente-Coronel, que designava um encarregado para proceder com as investigações e inquirições necessárias. Importante aclarar que em sede inquisitorial, buscavam-se tão somente indícios de autoria e materialidade, ou seja, indícios da ocorrência do crime e de quem o teria cometido, num prazo regulamentar de cinco dias, o qual poderia ser prorrogado, caso necessário, por mais três dias (art. 42 do Decreto $n^{\circ}$ 6.396/44).

Formava-se, então, um caderno investigativo, com documentos, laudos e termos de inquirições, os quais eram remetidos pelo encarregado ao Juiz Auditor que, em seguida, dava vista imediata ao promotor (representante do Ministério Público que oficiava perante a Auditoria) o qual, dentro de 24 horas, deveria verificar a conveniência de apresentar denúncia (art. 12 do Decreto $n^{\circ}$ 6.396/44) ou promoção de arquivamento.

${ }^{239}$ FREITAS, 78. 
Na denúncia, consoante a dicção do Decreto-Lei nº 6.396/44, deveria conter o nome do réu, a exposição sucinta dos fatos, a classificação do delito, a indicação das circunstâncias agravantes (que teriam o escopo de agravar a pena definida em lei) expressamente definidas na lei penal e a indicação das testemunhas.

Uma vez oferecida a denúncia, caberia novamente ao Juiz Auditor verificar se todos os requisitos estavam presentes e poderia proceder de duas formas: receber ou rejeitar a denúncia. Caso esta fosse rejeitada, era submetida a exame obrigatório pelo Conselho Supremo de Justiça Militar a quem competia a decisão final sobre seu recebimento ou rejeição da denúncia (art. 17 do Decreto nº 6.396/44).

De outro lado, recebida a denúncia, o réu era imediatamente citado (era levado ao conhecimento do acusado a abertura de processo contra ele), bem como eram intimadas as eventuais testemunhas arroladas pelo órgão de acusação, cujo número variava entre duas e quatro. Na hipótese da denúncia se fundar em prova documental, o rol de testemunhas seria dispensado. Um advogado de ofício, no posto de $2^{o}$ Tenente, encarregava-se da defesa do acusado, o qual poderia oferecer defesa escrita e juntar documentos no prazo de 24 horas.

Havia uma brecha na lei que permitia ao réu dispensar a assistência de um advogado caso julgasse estar em condições de fazer a sua própria defesa (art. 13, parágrafo único, do Decreto $\mathrm{n}^{\circ}$ 6.396/44). Tal dispositivo, na concepção do autor, só pode ser compreendido pela vontade do legislador de conceder celeridade à marcha processual ou dar proeminência à oralidade do julgamento, o que não justificaria a concessão ao réu do direito de ser condenado sem o auxílio de uma defesa técnica.

Pois bem. Um dia depois de efetivada a citação do réu, ocorreria a audiência de instrução e julgamento. Nessa audiência, as testemunhas eram inquiridas e, por último, o réu prestava declarações (art. 15 do Decreto $n^{\circ}$ 6.396/44). Importante destacar que o réu, caso quisesse, era dispensado de comparecer a essa audiência (art. 15, §4 $4^{\circ}$ do Decreto $\mathrm{n}^{\circ}$ 6.396/44). Dessa forma, fica evidente que, caso não estivesse instruído, um réu poderia ser condenado sem ouvir, sem ser ouvido e sem apresentar uma única defesa.

Finda a audiência de instrução, caso o réu fosse praça (cabo ou soldado) ou civil, o julgamento competia monocraticamente ao Juiz Auditor (julgava sozinho o caso, consoante seu próprio convencimento), que deveria proferir a sentença noutra audiência no prazo de 24 horas, sendo precedido por alegações orais da acusação e da defesa (art. 18 do Decreto $n^{\circ}$ 6.396/44). 
Sendo oficiais os acusados- até o posto de Tenente-Coronel-, era instituído um Conselho de Justiça (Auditor e dois oficiais nomeados pelo Comandante de Divisão, de patente igual ou superior ao acusado- os quais, destaque-se, não estiveram presentes na audiência de instrução, presidida pelo Auditor), órgão competente para julgá-los. Neste caso, após o compromisso, liam-se as peças do processo e, em seguida, depois dos debates orais que duravam, no máximo, 20 minutos para cada uma das partes fazer a sustentação, o Conselho reunia-se em sessão secreta para deliberar. A sentença deveria ser lavrada no prazo máximo de 24 horas (art. 19 do Decreto no 6.396/44).

Sendo Coronel ou Oficial-General o acusado, a competência para processá-lo e julgá-lo era do Conselho Supremo da Justiça Militar. Em tal hipótese, as funções do Ministério Público eram desempenhadas pelo Procurador-Geral, mas o rito processual era o mesmo utilizado nos crimes praticados por oficiais.

Contudo, da sentença proferida pelo CSJM, nos julgamentos de coronel ou generais, cabia, apenas e tão somente, recursos de embargos (art. 25 do Decreto $n^{\circ}$ 6.396/44). Os recursos de embargos se prestam a esclarecer uma dúvida, contradição ou obscuridade que tenha permanecido no dispositivo da sentença. Não havia oportunidade, portanto, de oferecer um recurso a fim de que fosse proferida uma nova análise (apelação) das sentenças do Conselho Superior, o que suprimia uma instância aos denunciados de patente superior.

Quanto aos processos instaurados para apuração do crime de deserção (cometido pelo expedicionário que se ausentasse de suas funções por quatro dias ou mais), havia um procedimento ainda mais célere (art. 27 do Decreto ${ }^{\circ}$ 6.396/44). É de ser ressaltado que o prazo de graça, em tempo de guerra, era de apenas 04 dias, ou seja, metade do prazo já previsto, então, para a deserção em tempo de paz (08 dias). Após o transcurso desse prazo, o Comandante do desertor faria lavrar um termo com todas as circunstâncias do fato, assinando-o, com duas testemunhas, o que já serviria para formação da culpa (apuração de autoria e materialidade).

Os documentos relativos à deserção deveriam ser remetidos, depois da apresentação voluntária ou da captura do réu, ao Juiz Auditor, e permaneceriam em cartório pelo prazo de 24 horas, com vista ao advogado de ofício, para apresentar defesa escrita. Seguia-se o julgamento pelo Auditor ou Conselho de Justiça, conforme o caso. Não havia denúncia oferecida pelo Ministério Público Militar, uma vez que o Termo de Deserção equivalia à formação da culpa. 
Quanto aos recursos das sentenças de $1^{\mathrm{a}}$ instância, cabia a Apelação, obrigatória à acusação (caso houvesse absolvição) e obrigatória à defesa (caso houvesse condenação). Ou seja, em última instância, não havia condenação ou absolvição sem o crivo anterior do CSJM (arts. 30 e 31 do Decreto $n^{\circ}$ 6.396/44).

Este era, em suma, o procedimento legal a ser adotado pela Justiça Militar, a fim de julgar um expedicionário da FEB.

Contudo, ademais de instituir o rito processual a ser seguido pelos membros da Justiça Expedicionária, impende destacar algumas curiosidades dispostas no Decreto $\mathrm{n}^{\circ}$ $6.396 / 44$.

A primeira delas é a constatação de não haver previsão legal de habeas corpus. $\mathrm{O}$ habeas corpus é um remédio judicial que se presta a fazer cessar a violência e coação que indivíduos possam estar sofrendo. A impetração dessa medida visa, em última instância, proteger o direito de ir e vir, a liberdade de locomoção do sujeito. O fato do artigo 41 do Decreto $n^{\circ}$ 6.396/44 expressamente lhe negar vigência, fala bastante sobre o significado da justiça e da vigência de certas garantias constitucionais em tempo de guerra.

Ademais, e corroborando com essa visão turva acerca das garantias que são tolhidas pelo próprio órgão incumbido de prover o melhor direito e a Justiça, salta aos olhos a leitura do art. 43 do Decreto ${ }^{\circ}$ 6.396/44, que assim dispõe:

\footnotetext{
"Art. 43. Nos casos de violência, praticada contra inferior, para compeli-lo ao cumprimento do dever legal, ou em repulsa à agressão, os autos do inquérito serão remetidos, diretamente, ao Conselho Supremo de Justiça Militar, que determinará o arquivamento, se o fato estiver justificado, ou a instauração do processo em caso contrário."
}

Ora, havia previsão clara e expressa autorizando o uso de violência contra inferior, a fim de compeli-lo ao cumprimento do dever legal ou em repulsa à agressão. Caso um soldado se negasse a cumprir uma ordem, seu superior poderia agredi-lo a fim de que o fizesse. E caso esse inferior lhe desrespeitasse, o superior, ademais de agredi-lo, poderia mandar prendê-lo, sem que houvesse previsão legal de ser solto, vez que era negada vigência à medida judicial cabível ao fato, o uso do habeas corpus.

O cenário retratado era, portanto, dos mais rigorosos, e a lei (Decreto $n^{\circ}$ 6.396/44) velava para que assim o fosse, com o fito de que, ao fim e ao cabo, a disciplina e a hierarquia da tropa fossem preservadas a todo custo. 
Por fim, a respeito da capitulação da pena de morte, havia a previsão de que esta ocorresse por meio de fuzilamento. E o Decreto $\mathrm{n}^{\circ} 6.396 / 44$, em seu art. 44, era explicito ao consignar a forma como ocorreria a execução e o uniforme que deveria ser vestido, uniforme comum e sem as insígnias, ademais de venda nos olhos no momento em que fosse receber as descargas. As vozes de fogo deveriam ser substituídas por sinais. Era, contudo, num ato de graça, facultado ao condenado receber socorros espirituais, caso assim o desejasse. Maiores detalhes a respeito da forma como se daria a execução não foram encontradas pelo autor em suas pesquisas aos atos normativos da época.

Contudo, uma vez consumada a execução da pena de morte, deveria ser lavrada uma ata circunstanciada que, assinada pelo executor e três testemunhas, seria remetida ao comandante-Chefe das Forças Expedicionárias, para ser publicada em ordem do dia ou boletim. Provavelmente, a publicação consistiria numa forma de tentativa de correção e manutenção da ordem na tropa, de forma indireta, através do exemplo e do temor.

\section{(iii) Visão panorâmica da atuação da Justiça Brasileira na Itália.}

Neste capitulo será exposto representativo resumo das atividades da Justiça da FEB na campanha da Itália. Contudo, a fim de melhor compreender a atuação daquela Justiça Expedicionária, é necessário, antes, compreender o cenário que permeava a Divisão Expedicionária Brasileira no Teatro de Guerra da Itália, no qual ela era chamada a aplicar as leis.

Nesse sentido, é importante inicialmente aclarar que o Exército americano tinha 16.624 oficiais e 249.441 praças quando Hitler invadiu a França em 1940, atingindo ao término das hostilidades o volumoso contingente de 772.863 oficiais e 7.305.854 praças $^{240}$. Uma vez que a incorporação de oficiais da reserva e conscritos do Exército Americano atingiu a casa da centena de milhares e a dos milhões, a tensão e os atritos entre profissionais e convocados tenderam à diluição ${ }^{241}$, com o passar da guerra.

Consequentemente, observados os hábitos de convívio entre praças e oficias americanos, a conclusão era que o Exército Americano se tornara uma corporação mais liberal e equilibrada no trato com os subalternos, mas que nem por isso apresentava menor eficácia em combate.

\footnotetext{
${ }^{240}$ STOUFFER, S. The American Soldier, Adjustment during Army Life, p. 54.

${ }^{241}$ Kennet, L. G.I. The American Soldier in World War II. Norman: University of Oklahoma Press, 1997. P. 66.
} 
Ao observarem as relações mais apaziguadas entre os militares de diferentes graduações do Exército Americano, a pergunta que muitos pracinhas se faziam era: "Por que, então, o Exército Brasileiro continuava a apresentar a mesma inflexibilidade em suas relações hierárquicas e disciplinares?"242.

É bem verdade que a missão francesa, conforme mencionado, ainda deixara hábitos arraigados. Contudo, o contato com unidades do Exército Americano havia posto em marcha um processo de mudança de influência, sentidos através do desenvolvimento de princípios igualitários na FEB.

Entretanto, paradoxalmente, essa influência, percebida através do surgimento de um trato disciplinar mais democrático, surgiu inicialmente nas unidades de combate, engajadas no front e que menos contato tinham com americanos.

Diferentemente da experiência americana, a incorporação dos milhares de civis no Exército Brasileiro não bastou para o estreitamento da cadeia hierárquica nas divisões expedicionárias. Tanto nos quartéis distribuídos pelo território nacional, quanto nas unidades da FEB alocadas a serviços de retaguarda, permaneceram claros os padrões disciplinares típico do "Exército Caxias".

No entanto, ainda que alguns oficiais fossem afeitos a hábitos menos hierarquizantes, o fator determinante e generalizante do relaxamento da disciplina foi o combate e a permanência no front. De outro lado, a proximidade de convívio entre oficiais e praças diminuía proporcionalmente ao afastamento da linha de frente ${ }^{243}$.

A hipótese de que o estreitamento de convívio entre oficiais e praças não ocorreu em toda a dimensão da tropa expedicionária, tendo se limitado às unidades de combate, é verificada por relatos de Oficiais da Reserva que compuseram a FEB, dentre eles o do $1^{\circ}$ Tenente R2 de Infantaria, José X. Góis de Andrade, segundo o qual:

\footnotetext{
"Quando cheguei à Itália, sento logo que os soldados dividiam em dois o Exército Nacional: referiam-se à FEB como a um "novo exército", bem diferente daquele outro exército que ficara no Brasil e que eles sempre ouviram chamar "Exército de Caxias".

(...) para o soldado, "Caxias" é o oficial, o sargento, o praça exagerado, rigoroso em demasia. É o militar que vive com o dedo nos artigos do Regulamento, sem a tolerância da equidade.

(...) "O Exército de Caxias", tão seu conhecido e tão diverso daquele outro, da FEB, que não era mais o mesmo e, o pracinha, ao contar as suas histórias e críticas da vida de quartel, precisava (...) a diferenciação real entre os dois "exércitos" estava na técnica. No poderio de suas nações diferentes. Uma
}

\footnotetext{
${ }^{242}$ MAXIMIANO, César Campiani. Barbudos, sujos e fatigados: soldados brasileiros na Segunda Guerra Mundial. São Paulo: Grua, 2010. P. 365.

${ }^{243}$ MAXIMIANO, César Campiani. Barbudos, sujos e fatigados: soldados brasileiros na Segunda Guerra Mundial. São Paulo: Grua, 2010. p. 374.
} 
adiantada e outra atrasada. A americana e a brasileira. Na primeira, o homem vale mais do que a máquina e o lema é:- Um homem se faz em vinte anos. Uma máquina em vinte minutos. Na segunda, a máquina vale amis do que o homem e o lema é: - Esta máquina custa os olhos da cara! Poupe-se a máquina! E o homem? Raios que o partam (...)"244

Isso leva a crer que imperava, na retaguarda, o mandonismo característico das tradições patriarcais e remanescente da missão francesa, que ainda regia o funcionamento das Forças Armadas brasileiras.

Em verdade, como um reflexo da vida civil, a disciplina nas casernas trazia a marca da disciplina coletiva. O poder do superior hierárquico se assemelhava ao poder do senhor de terras. O elemento disciplinador dominante ainda era o medo, o receio do castigo, o estabelecimento, enfim, de um modus vivendi desigual; e condição de "senhor" e de subordinado com as suas regalias e desvantagens.

O clima que imperava na retaguarda fica mais claramente explicitado através do testemunho prestado por Demócrito Cavalcante de Arruda ${ }^{245}, 1^{\text {o }}$ Tenente R2 de infantaria, comandante do pelotão de petrechos da $4^{\mathrm{a}}$ Companhia do $6^{\circ}$ R.I:

\begin{abstract}
"Nossos chefes, de modo geral, se apegam mais à letra de um regulamento de disciplina, por exemplo, que proíbe o inferior de fumar na presença do superior, ou não retirar a mão da pala, na continência, enquanto não receber autorização, do que à conquista da confiança dos homens pela tolerância, pelo tacto (sic), pela compreensão e interesse dos sentimentos dos subordinados. A consequência é que em lugar da cordialidade, existe nas fileiras uma surda hostilidade; a má vontade, em vez de uma solícita cooperação; direi mesmo uma atmosfera de temor que se exprime na desconfiança com que o nosso pracinha se aproxima da maioria dos nossos Generais, ou oficiais superiores. Porque a maioria das vezes em que um soldado encontra seu superior é dentro da rigidez protocolar do serviço e de uma calculada austeridade que só deixam raiva e decepção nos homens. Cria-se uma atmosfera de constrangimento para estes que, até em licença, preferem desviar-se do caminho a ter contacto (sic) com os seus Chefes.

(...) $\mathrm{Na}$ guerra, apesar do exemplo contagiante dos americanos, essa situação pouco mudou; as razões para o pouco contacto se acumularam e os soldados poucas vezes viam os seus generais, a não ser quando iam para a retaguarda, para serem, então, admoestados sobre um botão que faltava na túnica, sobre as botinas mal engraxadas, sobre uma continência mal feita, ou qualquer mesquinharia dessa espécie para homens que acabavam de sair dos "fox-holes" ou trincheiras da frente".
\end{abstract}

Com efeito, uma das coisas por que as praças, em geral, tinham antipatia era o rigor disciplinar que os divorciava dos oficiais. Há relatos que de tal antipatia não se restringia à diversificação dos ranchos, alojamentos, dos "círculos", mas à maneira de

\footnotetext{
${ }^{244}$ FEB. Depoimento de Oficiais da Reserva sobre a FEB. $3^{\text {a }}$ ed. Porto Alegre: COBRACI Publicações, s/d. p. 313 e 314.

${ }^{245}$ Idem. p.42.
} 
falar, à rigidez das atitudes e, principalmente, à continência em toda parte, a cada canto, a todo momento ${ }^{246}$.

O $1^{\mathrm{o}}$ Tenente Ruy de Oliveira Fonseca relatou uma experiência ocorrida no QG da $1^{\text {a }}$ D.I.E, numa ocasião em que os banhos estavam liberados para os oficiais vindos da linha de frente.

“Os banhos em Porretta estão franqueados, mas desta vez, quando fui lá direitinho, os oficiais do QG acordaram tarde e deram o golpe de estrelas em nós, tenentes. Quando reclamei, o sujeito era um major; quase fui preso e ainda levei um golpe sujo: depois de esperar na fila por mais de uma hora, o tal furou a fila e trancou-se no banheiro com a cara dura! Não volto mais lá. Nunca mais !, 247

Algumas semanas depois, o tenente Ruy teve a chance de visitar alguns companheiros recém-chegados à Itália junto com o Depósito Pessoal da FEB. Suas observações:

\begin{abstract}
"Passamos o dia apreciando o movimento daquela Unidade da FEB e demos graças a Deus de estarmos na frente de combate, pois ali o velho 'Caxias' andava solto, conforme os figurinos prescritos pelo R. Cont. (Regulamento de Continência), RISG (Regulamento de Instrução e Serviços Gerais) e RDE (Regulamento Disciplinar do Exército). Voltamos rapidamente, dando o maior valor às velhas casas de pedra dos contadini, naturalmente." 248
\end{abstract}

Em verdade, convém aclarar que a tropa do QG e o Depósito de Pessoal foram unidades que não restaram expostas aos períodos de linha de frente—onde a tendência se pautou por maior aproximação entre os combatentes, sobretudo em razão dos efeitos da guerra: o medo, o instinto de conservação e a camaradagem. Tais efeitos podem ser comprovados a partir do quadro a seguir exposto, que indica o perigo vivenciado pelos que serviam na linha de frente, demonstrando número de maior de mortos e feridos em relação àqueles órgãos que operavam na retaguarda:

Tabela 4: Quadro Geral dos mortos da FEB, por unidades

\begin{tabular}{|c|c|c|c|c|c|}
\hline Unidades & Em ação & Acidentados & Doenças & $\begin{array}{c}\text { Outros } \\
\text { motivos }\end{array}$ & Total \\
\hline $1^{\mathbf{0}}$ RI & 128 & 14 & - & 2 & 144 \\
\hline $6^{\circ}$ RI & 87 & 12 & 1 & 3 & 103 \\
\hline $1^{\mathbf{0}}$ RI & 116 & 5 & 2 & 1 & 124 \\
\hline I Grupo & 2 & - & - & - & 2 \\
\hline
\end{tabular}

${ }^{246}$ Idem. p. 367.

${ }^{247}$ Idem. p. 374.

${ }^{248}$ Idem. p. 375. 


\begin{tabular}{|c|c|c|c|c|c|}
\hline II Grupo & 1 & 3 & - & - & 4 \\
\hline III Grupo & 1 & 3 & - & - & 4 \\
\hline IV Grupo & - & 3 & 1 & - & 4 \\
\hline Btl Engenharia & 6 & 3 & - & - & 9 \\
\hline Btl Saúde & 5 & 1 & 1 & 1 & 8 \\
\hline $\begin{array}{c}\text { Esq } \\
\text { Reconhecimento }\end{array}$ & 3 & 1 & - & - & 4 \\
\hline Cia. Transmissões & 3 & 1 & - & - & 4 \\
\hline $\begin{array}{c}\text { Cia. De } \\
\text { Manutenção }\end{array}$ & 1 & 1 & - & - & 2 \\
\hline Cia. do QG & 1 & - & - & - & 1 \\
\hline Bia Cmdo da AD & - & 1 & - & - & 1 \\
\hline Cia. Intendência & - & 2 & - & - & 2 \\
\hline QG da DIE & - & 2 & - & 2 & 4 \\
\hline Cia. de Polícia & - & 1 & - & 1 & 2 \\
\hline Depósito de Pessoal & - & 7 & 4 & - & 11 \\
\hline Desconhecidos & 10 & - & - & - & 10 \\
\hline Total & 364 & 60 & 9 & 10 & $\overline{443}$ \\
\hline
\end{tabular}

Fonte: A Feb pelo seu Comandante. p. 314.

A despeito da maior exposição aos hábitos americanos nos órgãos de retaguarda da $1^{a}$ D.I.E, neles era notada uma alocação maior de oficiais em comparação aos regimentos engajados em combate, o que serve de indicativo do porquê da preservação da disciplina típica do Exército Brasileiro, que relembrava ao soldado da frente a vida militar no Brasil ("Exército Caxias").

E o homem do front sentiu isto de tal forma que consideraria um castigo se o enviassem para o Depósito ${ }^{249}$. É possível que os órgãos de retaguarda (QG e Depósito de Pessoal da FEB) tenham inspirado maior revolta dos que lá serviam, levando às "deserções ao contrário" ${ }^{250}$, exatamente por ser um ambiente no qual ainda predominava o habitual espírito dos quartéis no Brasil e, por ser comandado por um coronel conhecido pela forma desumana como tratava os subalternos.

A verificação se dá com o relato do $1^{\circ}$ Tenente R2 de Infantaria, José X. Góis de Andrade, segundo o qual:

“(...) O soldado da frente que batesse ali, estava frio. Não poderia sair, a não ser fugido; tinha que ficar naquela favela feita de pinheiros abatidos; sem contacto

\footnotetext{
${ }^{249}$ Idem. p. 369.

${ }^{250}$ Eram casos de soldados que fugiam da retaguarda em direção à linha de frente.
} 
(sic) com mulheres, sem distração, deslocado do ambiente dos seus camaradas do front. Acordava com a alvorada. Tinha que entrar em forma para os exercícios de ordem unida e combates simulados. E se quisesse sair por ali apenas com o elegante e confortável gorrinho de lã ao invés do capacete de aço, caiam-lhe em cima como vespas. Não fizesse continência aos duzentos oficiais que por ali vivam para ver uma coisa!

(...) Quando terminou a guerra, um sargento meu foi até lá, conseguir um meio de receber os seus vencimentos. Quando o sargento voltou, eu perguntei:

-Como vai o Depósito?

-Ah! Tenente, lá a guerra não terminou ainda! (...).,"251

Houve episódios em que soldados feridos no front, após se recuperarem do tratamento de saúde, foram lotados no Depósito de Pessoal, do qual fugiram, voltando à unidade de origem. A ânsia de permanecer junto aos companheiros, burlando algumas vezes a burocracia militar e cometendo transgressões para retornar à linha de frente, está registrada em documentos da Justiça Militar da FEB contemporâneos à guerra.

Numa ocasião, dois soldados do Depósito de Pessoal da FEB foram julgados por se rebelarem contra a intransigência que imperava naquela unidade. Segundo a sentença, os dois homens, após se embriagarem, receberam ordem de se dirigirem ao xadrez, ao que responderam nos seguintes termos:

"Não vou, não há quem me leve, e eu vou the quebrar todo, vou ajustar contas
com você, seu caxias filho da puta. Esta é a oportunidade que tenho para me
vingar deste caxias filho da puta, que só quer saber de dar instrução e traquejar.
Eu mato. Há muito que eu desejo tirar uma desforra dessa caxiagem.".252

Casos de indisciplina soam comuns a todos os exércitos, mas o conteúdo e as razões das vociferações daquele integrante do Depósito Pessoal parecem ser a reação a abusos sofridos.

Francisco Campello Salviano, que embarcou para a Itália num dos escalões que transportou o Depósito de Pessoal, em seguida foi designado para o $1^{\circ}$ Regimento de Infantaria. A respeito do Depósito, Salviano registrou que -“aquilo era um campo de concentração. Aquele coronel, Archimínio, não se de quê, era um tirano. Eu vi aquele homem estaquear um cabo naquele morro em frente ao Sampaio" ${ }^{253}$--.

Ademais de toda a tensão envolvida na experiência ímpar que a FEB vivenciava no Teatro Operacional da Itália, as divisões de retaguarda ainda haviam de se deparar com as cruéis práticas decorrentes do mandonismo que norteava o regulamento das Forças Armadas no Brasil, dentre as quais cita-se o "estaqueamento”, castigo corporal

\footnotetext{
${ }^{251}$ FEB. Depoimento de Oficiais da Reserva sobre a FEB. $3^{\text {a }}$ ed. Porto Alegre: COBRACI Publicações, s/d. p. 369 e 370 .

${ }^{252}$ Albuquerque. B.C.L. L. A Justiça Militar na Campanha da Itália. Fortaleza: Imprensa Oficial, 1958. p. 291.
} 
que, a despeito das poucas referências existentes, não estava em completo desuso nos anos 40, tendo havido situações extremas de agressão entre oficiais e praças na FEB.

Cumpre aqui rememorar o alarde feito no tópico anterior, no qual se demonstrou que no art. 43 do Decreto $n^{\circ}$ 6.396/44 havia previsão clara e expressa autorizando o uso de violência contra inferior, a fim de compeli-lo ao cumprimento do dever legal ou em repulsa à agressão.

Assim, na campanha da Itália, o uso da força bruta para manutenção da disciplina não se limitou aos estaqueamentos do Depósito de Pessoal, obrigando a intermitente ação da Justiça Militar da FEB, na tentativa de zelar pela disciplina em observância às normativa legais.

Dos tenentes mortos em combate, dois eram conhecidos por recorrerem ao emprego da força física para lidar com soldados impertinentes, de má conduta ou “respondões". Novamente o $1^{\circ}$ Tenente Ruy Leal Campello escreveu sobre um soldado que se apresentou, aparentemente embriagado, proferindo injúrias contra seu capitão ${ }^{254}$ :

\footnotetext{
"Quando o soldado, escoltado pelo sargento, já estava no corredor, o capitão a quem eu comunicara o que tinha acontecido, aproximou-se e ordenou-lhe: 'Repita o que você anda dizendo...' O soldado Cyro, com uma voz arrastada, talvez efeito do álcool, respondeu: 'São todos uns covardes...' De imediato, valente soco derruba o soldado no meio do corredor ... Todos os que ali se encontravam assistiram à cena e demonstraram satisfação com o encerramento do caso, sendo o soldado enviado preso ao PC/Btl."
}

Porém, a narrativa de Ruy Leal Campello não oferece o mesmo nível de detalhamento que o inquérito elaborado pela $1^{\mathrm{a}}$ Auditoria Militar da FEB. O homem acusado de embriaguez (citado na documentação oficial como tendo a graduação de cabo) teria dito que seu capitão era "covarde e sacana" e "que dos capitães que havia no Batalhão ele era o único que não tinha seguido os pelotões no combate ao Morro do Castelo". Na opinião dos julgadores, a intenção seria ferir a autoridade do capitão, o que teria invocado a atuação da Justiça Militar ${ }^{255}$.

Os indícios da ampla aversão à disciplina de caserna não se restringem a um punhado de relatos. O próprio comandante da FEB, general de divisão João Batista Mascarenhas de Moraes, teceu considerações sobre a resistência à disciplina militar observada na infantaria brasileira:

\footnotetext{
${ }^{253}$ MAXIMIANO, p. 376.

${ }^{254}$ Idem.

${ }^{255}$ ALBUQUERQUE, p. 107. A pena do cabo Cyro foi relativamente leve, de um ano, seis meses e vinte dias de prisão.
} 
'Nos riscos e angústias dos 'foxholes', os combatentes brasileiros adquiriram aquela esnobe arrogância, que lhes tirava a atitude militar e o cuidado no porte dos uniformes, em cujo esmero sobressaíam exemplarmente os soldados e oficiais americanos." 256

O pesquisador poderia perder o interesse em trabalhar e investigar os órgãos de retaguarda, se levasse em consideração o controverso relato de César Maximano—— $O s$ anais da Justiça Militar apontam menor ocorrência de infrações disciplinares registradas no Depósito de Pessoal e outros órgãos de retaguarda ${ }^{257}-$.-

Contudo, os dados estatísticos comprovam o contrário. Com efeito, houve maior incidência de delitos nos órgãos de retaguarda ${ }^{258}$, sobretudo na unidade de Depósito de Pessoal da FEB, onde estavam os expedicionários mais insatisfeitos; aqueles privilegiados postos de provisão e comando foram, em verdade, responsáveis por abrigar os delitos mais reprováveis aos olhos dos julgadores militares, conforme se demonstrará.

Somando-se as sanções penais aplicadas aos condenados pela Justiça Militar em tempo de guerra, tem-se um total de 406 anos, 11 meses e 24 dias de penas ${ }^{259}$. Houve duas condenações à pena capital, provenientes de expedicionários lotados em órgãos da retaguarda (as quais restarão detalhadas no próximo capítulo).

Em levantamento realizado na Seção de Arquivo do STM, onde estão armazenados os processos originados à época da Campanha da Itália, e em pesquisas realizadas em diversas publicações de época, pôde-se verificar que os crimes mais comuns cometidos durante a campanha da Itália foram os de deserção e os de lesão corporal. Registre-se que, antes mesmo do embarque, ou seja, no período de treinamento no Brasil, já haviam sido julgadas 28 deserções na $2^{\mathrm{a}}$ Auditoria da $1^{\mathrm{a}}$ Divisão de Infantaria do Exército.

Para uma visualização das diversas espécies de delitos militares cometidos durante a campanha italiana, seus autores, das sanções penais correspondentes e da composição dos órgãos da Justiça Militar e do Ministério Publico Militar, apresenta-se o elucidativo quadro a seguir:

\footnotetext{
${ }^{256}$ MASCARENHAS de Moraes, J.B. A FEB pelo seu comandante (para esta referência, $2^{\text {a }}$ edição, 1960), 303.

${ }^{257}$ A $1^{a}$ Auditoria da DIA registrou trinta julgamentos com elementos do Depósito de Pessoal para 66 com os demais órgãos divisionários. A $2^{\text {a }}$ Auditoria julgou 133 militares da FEB, dos quais 38 eram do Depósito de Pessoal. Grosso modo, o Depósito constituía 40\% do efetivo total da expedição. Albuquerque, p. 622, 628 e 629. Fonte: MAXIMIANO, p. 371.

${ }^{258}$ ALBUQUERQUE, p. 622 e 628.

${ }^{259}$ Idem. p. 620.
} 
Tabela 5: Natureza dos Crimes julgados pela Justiça Expedicionária

\begin{tabular}{|c|c|c|}
\hline NATUREZA & $1^{\mathrm{a}} \mathrm{AUD} / 1^{\mathrm{a}} \mathrm{DIE}$ & $2^{\mathrm{a}} \mathrm{AUD} / 1^{\mathrm{a}} \mathrm{DIE}$ \\
\hline Abandono de posto & 07 & 01 \\
\hline Lesão corporal dolosa & 10 & 14 \\
\hline Lesão corporal culposa & 07 & 12 \\
\hline Homicidio doloso & 02 & 02 \\
\hline Homicidio culposo & 04 & 10 \\
\hline Resistência & 02 & 01 \\
\hline Desacato & 08 & 13 \\
\hline Deserção & 14 & 28 \\
\hline Dano & 03 & - \\
\hline Roubo & 05 & 01 \\
\hline Furto & 09 & 10 \\
\hline Desobediência & 04 & 04 \\
\hline Peculato & 02 & 01 \\
\hline Crimes sexuais & 05 & 10 \\
\hline Violência contra superior & 03 & 04 \\
\hline Apropriação indébita & 02 & - \\
\hline Cobardia & 01 & 01 \\
\hline Insubordinação & 04 & 05 \\
\hline Desrespeito a superior & 01 & - \\
\hline Falsidade & 01 & - \\
\hline Abandono de posto & - & 01 \\
\hline
\end{tabular}

$\underline{\text { Resumo Estatístico das Auditorias da } 1^{\text {a }} \text { Divisão de Infantaria Expedicionária }}$

\section{- DISTRIBUIÇÃO DE PROCESSOS}

A $2^{\text {a }}$ Auditoria, por ser o seu titular o Juiz Auditor mais antigo, tinha a seu encargo, por disposição legal, a incumbência da distribuição dos processos.

Durante o funcionamento, foi feita a seguinte distribuição:

$\mathbf{1}^{\mathrm{a}}$ Auditoria - Processos de Oficiais (07) + Praças e civis (128) $=\mathbf{1 3 5}$

$\mathbf{2}^{\mathbf{a}}$ Auditoria - Processos de Oficiais (06) + Praças e civis (130) $=136$ 
- TOTAL DAS PENAS APLICADAS

A Justiça Militar de $1^{\text {a }}$ instância da FEB, aplicou um total de 406 anos, 11 meses e 24 dias de penas restritivas da liberdade (reclusão, detenção e prisão), assim distribuídas:

- $\mathbf{1}^{\text {a }}$ Auditoria - Juiz Auditor Ten Cel Dr Adalberto Barreto = 206Anos 09Meses 22Dias

- 2a Auditoria - Juiz Auditor Ten Cel Dr Eugênio Carvalho do Nascimento = 200Anos 02Meses 02Dias

Tabela 6: Réus julgados pelas Auditorias Militares de Campanha

\begin{tabular}{|l|c|c|c|c|}
\cline { 2 - 5 } \multicolumn{2}{l|}{} & \multicolumn{2}{c|}{$1^{\mathrm{a}}$ AUD/1 ${ }^{\mathrm{a}}$ DIE } & \multicolumn{2}{c|}{$2^{\mathrm{a}}$ AUD/1 ${ }^{\mathrm{a}}$ DIE } \\
\hline CIVIL & 01 & & 02 & 01 \\
\hline SOLDADO & 66 & 14 & & - \\
\hline CABO & 06 & 04 & 65 & 38 \\
\hline SARGENTO & 01 & 01 & 03 & 03 \\
\hline $1^{\circ}$ TENENTE R2 & 01 & 01 & - & 05 \\
\hline $2^{\circ}$ TENENTE R1 & 01 & - & - & - \\
\hline $2^{\circ}$ TENENTE R2 & - & 01 & 01 & - \\
\hline SUBTENENTE & - & - & 01 & - \\
\hline
\end{tabular}

A $1^{\text {a }}$ Auditoria da $1^{\text {a }}$ Divisão de Infantaria do Exército proferiu sentença em 96 processos (76 condenações e 21 absolvições). Apenas um civil foi julgado, tendo sido condenado. Em comparação, 80 militares foram julgados, sendo que 66 soldados foram condenados e 14 absolvidos. Dentre os militares, 02 Sargentos foram julgados, sendo um deles condenado e o outo absolvido. Da mesma forma, $021^{\circ}$ Tenentes foram processados e julgados, com uma condenação e uma absolvição. Ao todo, a $1^{\text {a }}$ Auditoria foi responsável pela aplicação de 206 anos, nove meses e 22 dias em penas. 
A seguir, expõe-se em detalhes os julgamentos efetivos pelo Juízo da $1^{\text {a }}$ Auditoria, com citação das iniciais dos envolvidos, delitos que lhes foram imputados e menção ao cumprimento da pena ${ }^{260}$ :

Ten. Cel. Adalberto Barreto-

Juiz da $1^{\text {a }}$ Auditoria da $1^{\text {a }}$ D.I.E

\begin{tabular}{|c|c|c|}
\hline ENVOLVIDO & DELITO IMPUTADO & PENA \\
\hline $\begin{array}{c}\text { J.V. } \\
\text { Soldado da } 5^{\mathrm{a}} \text { Cia. de Depósito } \\
\text { Pessoal }\end{array}$ & Desacato a superior & Indultado \\
\hline $\begin{array}{c}\text { O.B. } 3^{\circ} \text { Sgt. Manipulador de } \\
\text { Farmácia }\end{array}$ & Embriaguez em Serviço & Absolvido \\
\hline $\begin{array}{c}\text { A. A. da S. Soldado do } 9^{\circ} \\
\text { B.E }\end{array}$ & Uso indevido de insígnia & Indultado \\
\hline $\begin{array}{c}\text { A. } \text { L. } \\
\text { Soldado do Depósito do } \\
1^{\circ} \text { R.I. }\end{array}$ & Desrespeito a superior & Indultado \\
\hline $\begin{array}{l}\text { M.G. da S. Soldado do Depósito } \\
\text { Pessoal }\end{array}$ & Desacato a superior & Indultado \\
\hline $\begin{array}{l}\text { A.J.N Soldado do Regimento } \\
\text { Sampaio }\end{array}$ & Desacato a superior & Indultado \\
\hline $\begin{array}{l}\text { H. da S. Cabo do } 6^{\circ} \text { Regimento de } \\
\text { Infantaria }\end{array}$ & $\begin{array}{c}\text { Desacato a superior e oposição à } \\
\text { execução de ato legal }\end{array}$ & Indultado \\
\hline $\begin{array}{c}\text { C.J. da S. Soldado do Depósito } \\
\text { Pessoal da FEB }\end{array}$ & $\begin{array}{c}\text { Desacato e violência contra superior. } \\
\text { Lesão Corporal }\end{array}$ & Indultado \\
\hline $\begin{array}{l}\text { M.M. } \\
\text { M.I. da S. } \\
\text { Soldados do Depósito Pessoal da } \\
\text { FEB }\end{array}$ & Peculato & Indultado \\
\hline $\begin{array}{l}\text { L.C. de S. } \\
\text { Soldado do Depósito Pessoal da } \\
\text { FEB }\end{array}$ & Lesão Corporal & Absolvido \\
\hline $\begin{array}{c}\text { J.V.C. Soldado do Depósito } \\
\text { Pessoal da FEB }\end{array}$ & Desacato a superior & Indultado \\
\hline $\begin{array}{c}\text { A.V. de J. Soldado do Depósito de } \\
\text { Pessoal da FEB }\end{array}$ & $\begin{array}{l}\text { Desacato e violência contra superior. } \\
\text { Lesão Corporal }\end{array}$ & Indultado \\
\hline $\begin{array}{c}\text { B.P.C. } \\
\text { Soldado do } 1^{\circ} \text { Batalhão de }\end{array}$ & Deserção & Indultado \\
\hline
\end{tabular}

${ }^{260}$ A tabela apresentada com todos os feitos processados e julgados pela Justiça Expedicionária Brasileira no Teatro Operacional da Itália (1944-1945) foi obtida a partir de consulta ao livro: Albuquerque. B.C.L. L. A Justiça Militar na Campanha da Itália. Fortaleza: Imprensa Oficial, 1958. p. 291. 


\begin{tabular}{|c|c|c|}
\hline Infantaria & & \\
\hline W.M. da S. & Deserção & Absolvido \\
\hline $\begin{array}{l}\text { H.P. C. Soldado do Depósito de } \\
\text { Pessoal da FEB }\end{array}$ & Deserção & Processo nulo \\
\hline $\begin{array}{c}\text { P.A.S } \\
\text { Cabo do } \text { 11 }^{\circ} \text { Rgt de Infantaria }\end{array}$ & Deserção & Processo nulo \\
\hline $\begin{array}{c}\text { J.F. do A. } \\
\text { Cabo do Dep. De Pessoal da FEB }\end{array}$ & Deserção & Processo nulo \\
\hline $\begin{array}{c}\text { P.T. Soldado do Depósito de } \\
\text { Pessoal da FEB }\end{array}$ & Deserção & Processo nulo \\
\hline $\begin{array}{c}\text { R.M.P. Soldado do Dep. de } \\
\text { Pessoal da FEB }\end{array}$ & Deserção & Processo nulo \\
\hline E.A. da S. Soldado do $4^{\circ}$ G.A. & Deserção & Processo nulo \\
\hline $\begin{array}{c}\text { C.de O. } \\
\text { Soldado do Dep. de Pessoal da } \\
\text { FEB }\end{array}$ & Deserção & Absolvido \\
\hline $\begin{array}{c}\text { L.N. } \\
\text { Soldado do } 11^{\circ} \text { Rgt de Infantaria }\end{array}$ & Deserção & Absolvido \\
\hline $\begin{array}{l}\text { D.N. Soldado do Dep. de Pessoal } \\
\text { da FEB }\end{array}$ & Deserção & Processo nulo \\
\hline $\begin{array}{c}\text { A.dos S.A. } \\
\text { Soldado do Dep. Pessoal da FEB }\end{array}$ & Deserção & Processo nulo \\
\hline $\begin{array}{c}\text { W. de A. R. } \\
\text { Soldado do Dep. Pessoal da FEB }\end{array}$ & Deserção & Processo nulo \\
\hline $\begin{array}{c}\text { M.B.S. Cabo do Dep. Pessoal da } \\
\text { FEB }\end{array}$ & Deserção & Processo nulo \\
\hline $\begin{array}{c}\text { O. dos S.R. Aspirante a Oficial do } \\
\text { Dep. Pessoal da FEB }\end{array}$ & Homicídio culposo & Indultado \\
\hline
\end{tabular}

A. A. M.

Soldado do Dep. de Pessoal

da FEB
Deserção

Indultado

\section{M.B.S.}

E.C.

Desacato a Superior

Indultados

Soldados do $6^{\circ}$ Rgt de Infantaria

J.H.S.

Soldado do Departamento do

Pessoal da FEB

H.M. da S.

Soldado do Departamento do

Furto

Indultado

Pessoal da FEB

A. X. P

Desacato a Superior

Indultado

Cabo do Depto do Pessoal da FEB
A. B. S.
Lesão Corporal
Indultado

Cabo do I Batalhão de Saúde 


\begin{tabular}{|c|c|c|}
\hline $\begin{array}{c}\text { J.G. Soldado do I Batalhão de } \\
\text { Saúde }\end{array}$ & Desaparecimento de viatura militar & Indultado \\
\hline $\begin{array}{l}\text { L.G.B. } \\
\text { Soldado do Dep. de Pessoal da } \\
\text { FEB }\end{array}$ & Deserção & Indultado \\
\hline $\begin{array}{c}\text { G. R. } \\
\text { Soldado do Regimento Sampaio }\end{array}$ & Deserção & Indultado \\
\hline $\begin{array}{l}\text { S. D. Soldado do Dep. de Pessoal } \\
\text { da FEB }\end{array}$ & Deserção & Indultado \\
\hline 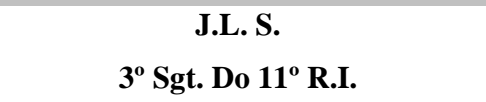 & Deserção & Indultado \\
\hline $\begin{array}{c}\text { A. } \text { de S. C. } \\
\text { Soldado do } 6^{\circ} \text { R.I. }\end{array}$ & Deserção & Indultado \\
\hline $\begin{array}{l}\text { J.B. } \\
\text { Soldado do Dep. de Pessoal da } \\
\text { FEB }\end{array}$ & Deserção & Indultado \\
\hline $\begin{array}{c}\text { A. } \text { R. } \\
\text { Soldado do Dep. de Pessoal } \\
\text { da FEB }\end{array}$ & Deserção & Indultado \\
\hline $\begin{array}{c}\text { J.P. B } \\
\text { Soldado da Cia de Intendência da } \\
\text { DIE }\end{array}$ & Deserção & Indultado \\
\hline W.M. & Lesão Corporal & Absolvido \\
\hline $\begin{array}{c}\text { J.M. A. dos S. } \\
\text { 30 Sargento da Cia de Manutenção }^{\text {Leve }}\end{array}$ & Furto & Indultado \\
\hline R. S. (italiano) & Homicídio culposo & Absolvido \\
\hline $\begin{array}{c}\text { A.R.S. } \\
\text { Soldado do } 1^{\circ} \text { G.A. }\end{array}$ & Lesão Corporal & Absolvido \\
\hline $\begin{array}{c}\text { A.N. da S. } \\
\text { Cabo da Cia. do Q.G. da } 1^{\text {a }} \text { DIE }\end{array}$ & Lesão Corporal & Absolvido \\
\hline $\begin{array}{l}\text { J. de C.M.- soldado N.F.J.- cabo } \\
\text { da } 2^{\text {a }} \text { G.A. }\end{array}$ & Fuga de Preso & Indultado \\
\hline $\begin{array}{c}\text { J.S. } \\
\text { Soldado do Batalhão de Saúde }\end{array}$ & Lesão Corporal & Indultado \\
\hline $\begin{array}{c}\text { A.L. } \\
\text { Cabo do } 18^{\circ} \text { R.I. }\end{array}$ & Oposição à execução de ato legal & Indultado \\
\hline $\begin{array}{c}\text { E.P. } \\
\text { Soldado do } 6^{\circ} \text { R.I. }\end{array}$ & Conjunção Carnal & Indultado \\
\hline $\begin{array}{l}\text { A.T.B. } \\
\text { Soldado do II Grupo de Artilharia }\end{array}$ & Lesão Corporal & Indultado \\
\hline $\begin{array}{c}\text { M.B.S } \\
\text { E.C. } \\
\text { Soldados do } 6^{\circ} \text { Rgt de Infantaria }\end{array}$ & Desacato a Superior & Indultados \\
\hline
\end{tabular}




\begin{tabular}{ccc}
\hline J.H.S. & & \\
Soldado do Departamento do & Furto & Indultado \\
Pessoal da FEB & & \\
H.M. da S. & Furto & Indultado \\
Soldado do Departamento do & & \\
Pessoal da FEB & Indultado \\
A.X.P. & Lesão Corporal & Indultado a superior \\
Cabo do Depto do Pessoal da FEB & & Indultado \\
A.B.S. & & \\
\hline Cabo do I Batalhão de Saúde & & \\
J.G. & & Desaparecimento de viatura militar \\
\hline
\end{tabular}

No mesmo período, a $2^{\mathrm{a}}$ Auditoria da $1^{\mathrm{a}}$ D.I.E julgou 119 réus (72 condenadas e 47 absolvidas). Um oficial, um Subtenente, 03 Sargentos, 65 Cabos e Soldados e dois civis foram condenados, ao passo que 05 oficiais, 03 Sargentos, 38 Cabos e Soldados e um civil foram absolvidos. Pela Defesa foram interpostos 72 recursos de apelação, enquanto o Ministério Público Militar só recorreu de 06 absolvições. A $2^{\text {a }}$ Auditoria foi responsável pela aplicação de 200 anos, dois meses e dois dias em penas.

Apesar da contabilização de penas ter sido menor, a $2^{\mathrm{a}}$ Auditoria foi o órgão judicante que permaneceu por mais tempo na Itália, julgou o maior número de casos, 98, e sentenciou as penas mais severas, dentre elas, a pena capital a dois pracinhas da FEB. Assim, o Tenente-Coronel Eugênio Carvalho do Nascimento, responsável pela $2^{\mathrm{a}}$ Auditoria, foi o único juiz, depois de proclamada a República, a condenar dois réus à morte.

Os dois brasileiros condenados ao fuzilamento eram soldados do Pelotão de Defesa do QG de Retaguarda e foram julgados em Pistóia. Denunciados nos tipos do Código Penal Militar de 1944, que tratavam de homicídio e violência sexual, apesar de sentenciados apenas na pena do homicídio; tiveram a pena confirmada no Conselho Supremo de Justiça Militar, conforme será detalhado no capítulo seguinte.

À semelhança do exposto em relação aos julgados da $1^{\mathrm{a}}$ Auditoria, seguem síntese do trabalho realizado pela $2^{\mathrm{a}}$ Auditoria no Teatro de Operações da Itália: 
Ten. Cel. Eugênio Carvalho do Nascimento-

Juiz Auditor da $2^{\text {a }}$ Auditoria da $1^{\text {a }}$ D.I.E

\begin{tabular}{ccc}
\hline ENVOLVIDO & DELITO IMPUTADO & PENA \\
\hline S. dos S. & Homicídio culposo & Indultado \\
Sd $3^{\text {a }}$ Bia $/ 3^{\circ}$ Grupo & & Absolvido \\
A.C. & Desacato a superior &
\end{tabular}

$3^{\circ}$ Sgt. do IV G.A.

$\begin{array}{|ccc|}\text { A.F.L. } & \text { Homicídio culposo } & \text { Absolvido } \\ \text { P.P. } & & \\ \text { Soldado do Depósito de Pessoal da } & \text { Desrespeito a superior } & \text { Absolvido } \\ \text { FEB } & & \\ \text { W.A.R } & \text { Violência contra superior } & \text { Absolvido } \\ \text { Soldado do } \mathbf{1}^{\mathbf{0}} \text { R.I. } & & \\ \text { L.C. dos S. } & \text { Desrespeito a superior } & \text { Absolvido }\end{array}$

Soldado do $11^{\circ}$ R.I.

$\begin{array}{|ccc|}\text { H.S. } & \text { Insubordinação } & \text { Extinta a punibilidade } \\ \text { Soldado do } \mathbf{3}^{\circ} \text { Grupo de Artilharia } & & \\ \text { A.R. da S. } & \text { Abuso de autoridade } & \text { Extinta a punibilidade } \\ \text { Soldado do } \mathbf{1}^{\circ} \text { Grupo de Artilharia } & & \\ \text { L.N.D. } & \text { Furto } & \text { Extinta a punibilidade } \\ \text { Soldado do Depósito de Pessoal do } & & \\ \mathbf{5}^{\circ} \text { Btl. } & & \end{array}$

R.S.- Cabo

N. de O.- Soldado do Correio Reg Furto Extinta a punibilidade

de Nápoles

G..J. do N. Deserção Absolvido

Soldado do $3^{\circ}$ Grupo da A.D.

O.O. de O. Deserção Absolvido

Soldado do Regimento Sampaio

\begin{tabular}{|c|c|c|}
\hline $\begin{array}{c}\text { V.C.V. } \\
3^{\text {o }} \text { Sgt. do Regimento Sampaio }\end{array}$ & Deserção & Absolvido \\
\hline $\begin{array}{l}\text { V. de P. da C. } \\
\text { Soldado do Dep. de Pessoal da } \\
\text { FEB }\end{array}$ & Deserção & Absolvido \\
\hline $\begin{array}{c}\text { F.D.D. } \\
\text { Soldado do Regimento Sampaio }\end{array}$ & Deserção & Absolvido \\
\hline $\begin{array}{c}\text { A.P.G. } \\
\text { Soldado do Regimento Sampaio }\end{array}$ & Deserção & Absolvido \\
\hline $\begin{array}{l}\text { G.J. da S. } \\
\text { Soldado do Dep. de Pessoal da } \\
\text { FEB }\end{array}$ & Deserção & Absolvido \\
\hline
\end{tabular}

J.A. dos S. 


\begin{tabular}{|c|c|c|}
\hline $\begin{array}{c}\text { Soldados do Dep. de Pessoal da } \\
\text { FEB }\end{array}$ & Deserção & Absolvido \\
\hline $\begin{array}{c}\text { V. de P. da C. } \\
\text { Soldado do Dep. de Pessoal da } \\
\text { FEB }\end{array}$ & Deserção & Absolvido \\
\hline $\begin{array}{l}\text { E. A. de O. } \\
\text { Soldado do Dep. de Pessoal da } \\
\text { FEB. }\end{array}$ & Deserção & Absolvido \\
\hline $\begin{array}{c}\text { J. M. da C. } \\
\text { Soldado do Rgt. Sampaio }\end{array}$ & Deserção & Absolvido \\
\hline $\begin{array}{c}\text { E. R. } \\
\text { Soldado do } \mathbf{1 1}^{\circ} \text { R.I. }\end{array}$ & Deserção & Absolvido \\
\hline $\begin{array}{c}\text { I.P. de S. } \\
\text { Soldado do Rgt Sampaio }\end{array}$ & Deserção & Absolvido \\
\hline N.P. & Deserção & Processo nulo \\
\hline $\begin{array}{l}\text { J.S. de M. } \\
\text { Soldado do Dep. de Pessoal da } \\
\text { FEB }\end{array}$ & Deserção & Absolvido \\
\hline $\begin{array}{l}\text { S. S. } \\
\text { Soldado do Dep. de Pessoal da } \\
\text { FEB }\end{array}$ & Deserção & Absolvido \\
\hline $\begin{array}{c}\text { A. da S. } \\
\text { Soldado do Dep. de Pessoal } \\
\text { da FEB }\end{array}$ & Deserção & Absolvido \\
\hline $\begin{array}{l}\text { A.V. } \\
\text { Soldado do Dep. de Pessoal da } \\
\text { FEB }\end{array}$ & Deserção & Nulo \\
\hline $\begin{array}{c}\text { A.M. das N. } \\
\text { Soldado do C.I. }\end{array}$ & Deserção & Extinta a punibilidade \\
\hline $\begin{array}{l}\text { J. A. da S. } \\
\text { Soldado do Dep. de Pessoal da } \\
\text { FEB }\end{array}$ & Deserção & Extinta a punibilidade \\
\hline $\begin{array}{c}\text { I.P. de S. } \\
\text { Cabo do } 1^{\circ} \text { Grupo do Rgt } \\
\text { Sampaio }\end{array}$ & Deserção & Extinta a punibilidade \\
\hline $\begin{array}{c}\text { J.A. das S. } \\
\text { Soldado do Rgt. Sampaio }\end{array}$ & Deserção & Extinta a punibilidade \\
\hline $\begin{array}{c}\text { L. A. de O. } \\
\text { Soldado do Rgt. Sampaio }\end{array}$ & Deserção & Extinta a punibilidade \\
\hline R.A. de O. & Deserção & Processo nulo \\
\hline $\begin{array}{c}\text { M.M. } \\
\text { Soldado do II/1 }{ }^{\circ} \text { R.O. }\end{array}$ & Lesão Corporal & Absolvido \\
\hline $\begin{array}{c}\text { H.A. dos S. } \\
\text { Soldado do II } / 1^{\circ} \text { R.O. }\end{array}$ & Homicídio culposo & Absolvido \\
\hline
\end{tabular}




\begin{tabular}{|c|c|c|}
\hline $\begin{array}{c}\text { N.R. de } S . \\
\text { R.P. de } S . \\
\text { Soldados } \\
\text { O.B.L.- Cabo- } 1^{\circ} \text { R.I. }\end{array}$ & Lesão Corporal & Absolvidos \\
\hline $\begin{array}{c}\text { A.B. } \\
\text { Soldado do } 1^{\circ} \text { R.I. }\end{array}$ & $\begin{array}{c}\text { Abandono de posto em presença do } \\
\text { inimigo }\end{array}$ & $\begin{array}{c}\text { Extinta a ação penal por falecimento } \\
\text { do réu }\end{array}$ \\
\hline $\begin{array}{l}\text { E.P. } \\
\text { Soldado do II Grupo de Artilharia }\end{array}$ & Negligência no exercício da função & Absolvido \\
\hline $\begin{array}{l}\text { U. de A. } \\
\text { Soldado do Serviço Especial da } \\
\text { FEB }\end{array}$ & Lesão Corporal & Indultado \\
\hline $\begin{array}{c}\text { W. C. } \\
\text { Soldado do Serviço Especial da } \\
\text { FEB }\end{array}$ & Homicídio & Absolvido \\
\hline $\begin{array}{c}\text { J.M. de F. } \\
\text { Soldado do } 11^{\circ} \text { Regimento de } \\
\text { Infantaria }\end{array}$ & Lesão Corporal & Absolvido \\
\hline $\begin{array}{c}\text { D. da L. L. } \\
\text { Soldado da Pagadoria fixa }\end{array}$ & Lesão corporal & Absolvido \\
\hline $\begin{array}{c}\text { M.J.D. } \\
\text { Soldado do III Grupo de } \\
\text { Artilharia }\end{array}$ & Homicídio culposo & Extinta a punibilidade \\
\hline
\end{tabular}

A respeito do órgão supremo de julgamento da Justiça Expedicionária, o Conselho Supremo de Justiça Militar, convém destacar que foi responsável por julgar, no total, 121 apelações, tendo realizado 65 sessões, sendo 14 na Itália e 51 em território nacional. Além disso, se pronunciou em 32 casos de arquivamento de inquérito policialmilitar, em uma única rejeição de denúncia e em 03 revisões criminais, tendo examinado, também, 04 prisões em flagrante ${ }^{261}$.

Julgadores:

Gen. Boanerges Lopes de Souza-Presidente

Gen. Washington Vaz de Melo

Gen. Francisco de Paula Cidade

Gen. Waldemiro Gomes Ferreira- Procurador-Geral

\begin{tabular}{ccc}
\hline ENVOLVIDO & DELITO IMPUTADO & PENA \\
\hline J. da S. & Abandono de posto & 2 meses e 20 dias de prisão simples \\
Soldado do $\mathbf{1}^{\circ}$ Rgt de obuses AR & & \\
\hline
\end{tabular}

${ }^{261}$ Idem. p. 621. 


\begin{tabular}{|c|c|c|}
\hline $\begin{array}{c}\text { J.M. } \\
\text { Soldado do Rgt Sampaio }\end{array}$ & Desacato a Superior & 2 anos de reclusão \\
\hline $\begin{array}{c}\text { C.P.B } \\
\text { Soldado da } 3^{\text {a }} \text { Bia do } 1^{\circ} \text { Rgt de } \\
\text { Art. P. C. }\end{array}$ & Lesão Corporal & 5 meses e 10 dias de prisão simples \\
\hline $\begin{array}{c}\text { A. de. A. } \\
\text { Soldado do } 1^{\circ} \text { G do } 2^{\circ} \text { Rgt } \\
\text { Obuses AR }\end{array}$ & Desobediência à ordem legal & 6 meses e 20 dias de prisão simples \\
\hline $\begin{array}{c}\text { P.T. dos R. } \\
\text { Soldado do II/1 R.G. }\end{array}$ & Agressão a superior & 2 anos e 8 meses \\
\hline $\begin{array}{c}\text { M.F. } \\
\text { Soldado do } 6^{\circ} \text { R.I. }\end{array}$ & Deserção & 3 meses e 5 dias \\
\hline $\begin{array}{c}\text { R.T. } \\
\text { Cabo do } 6^{\circ} \text { R.I. }\end{array}$ & $\begin{array}{l}\text { Homicídio doloso e lesões corporais } \\
\text { culposas }\end{array}$ & $\begin{array}{c}10 \text { anos e } 3 \text { meses (homicídio) e } 2 \\
\text { meses e } 26 \text { dias (lesões) }\end{array}$ \\
\hline $\begin{array}{c}\text { A. } \quad \text { R. de L. } \\
\text { Soldado do } 6^{\circ} \text { R.I. }\end{array}$ & Deserção & 3 anos de detenção \\
\hline $\begin{array}{c}\text { M.G. } \\
\text { J.A. de Q. } \\
\text { Soldados } 3^{\circ} \text { Bia } \\
\text { do II/1 } \mathbf{1}^{\circ} \text { R.O.AR }\end{array}$ & Conjunção carnal & 2 anos de reclusão \\
\hline $\begin{array}{c}\text { H.C. } \\
3^{o} \text { Sgt da Cia de Manutenção }\end{array}$ & Incêndio culposo & 8 meses e 20 dias de prisão simples \\
\hline $\begin{array}{l}\text { J. N. } \\
\text { Soldado do Batalhão de Saúde }\end{array}$ & Dano & Absolvido \\
\hline $\begin{array}{c}\text { C.P. } \operatorname{dos} S . \\
1^{\circ} \text { Ten. Do } 11^{\circ} \text { R.I. }\end{array}$ & Homicídio culposo & 20 meses de prisão \\
\hline $\begin{array}{c}\text { A.A. } \\
\text { M.B. } \\
\text { P.O. } \\
\text { A.C. } \\
\text { A.S.S } \\
\text { Soldados de Dep. de Pessoal }\end{array}$ & Roubo e extorsão & $\begin{array}{l}\text { A.A.: } 12 \text { anos, } 11 \text { meses e } 2 \text { dias. } \\
\text { M.B: } 13 \text { anos. } \\
\text { P.O.: } 12 \text { anos e } 12 \text { dias. } \\
\text { A.C.: } 11 \text { anos e } 30 \text { dias. } \\
\text { A.S.S.: Absolvido }\end{array}$ \\
\hline $\begin{array}{c}\text { J.V.P. } \\
\text { Soldado do } 11^{\circ} \text { B.I. }\end{array}$ & Desobediência à ordem legal & 6 meses e 6 dias \\
\hline $\begin{array}{c}\text { B.L.F. dos S. } \\
\text { Soldado do } 9 \text { B.E }\end{array}$ & Furto & 1 ano e 6 meses de reclusão \\
\hline $\begin{array}{c}\text { C.M. } \\
\text { Cabo do Reg. Sampaio }\end{array}$ & Desacato a superior & 1 ano, 6 meses de reclusão \\
\hline $\begin{array}{c}\text { P.C. } \\
\text { Soldado do } 6^{\circ} \text { B.I. }\end{array}$ & Desacato a superior & 1 ano e 8 meses de reclusão \\
\hline $\begin{array}{c}\text { A.N. da V. } \\
\text { Soldado do } 11^{\circ} \text { B.I. }\end{array}$ & Desacato a superior & 1 ano, 6 meses e 20 dias \\
\hline $\begin{array}{c}\text { B.L. } \\
\text { Soldado do } 9^{\circ} \text { B.E. }\end{array}$ & Embriaguez em serviço & 2 anos, 1 mês e 10 dias \\
\hline
\end{tabular}




\begin{tabular}{|c|c|c|}
\hline $\begin{array}{c}\text { A.R.F. } \\
\text { Soldado da Cia do Dep. de } \\
\text { Intendência }\end{array}$ & Embriaguez em serviço & 1 ano, 5 meses e 10 dias \\
\hline $\begin{array}{c}\text { A.D.P e L.B. de M. } \\
\text { Soldados do Pelotão de Defesa do } \\
\text { QG da } 1^{\text {a }} \text { DIE }\end{array}$ & $\begin{array}{c}\text { Conjunção Carnal. } \\
\text { Homicídio }\end{array}$ & Pena de morte \\
\hline $\begin{array}{c}\text { O.L.F do } \mathrm{P} \text {. } \\
2^{\circ} \text { Ten. do } 7^{\circ} \text { Station- Hospital } \\
\text { Seção Brasileira }\end{array}$ & Peculato & 4 anos, 1 mês e 10 dias \\
\hline $\begin{array}{c}\text { E.F.B. } \\
\text { Soldado da } 9^{\text {a }} \text { Cia. do Depósito de } \\
\text { Pessoal }\end{array}$ & Desobediência à ordem legal & 8 meses de prisão \\
\hline $\begin{array}{c}\text { J.Q. } \\
\text { Soldado da } 6^{\text {a }} \text { R.I. }\end{array}$ & Deserção & 9 meses e 22 dias \\
\hline $\begin{array}{c}\text { F.A.M } \\
\text { Soldado do I/22 R.O. } \\
\text { Autorrebocado }\end{array}$ & Conjunção carnal & 1 ano, 4 meses e 15 dias \\
\hline $\begin{array}{c}\text { J.C. } \\
\text { Soldado do Batalhão de Saúde }\end{array}$ & $\begin{array}{c}\text { Desobediência à ordem legal e } \\
\text { desacato à superior }\end{array}$ & 3 anos e 4 meses \\
\hline $\begin{array}{c}\text { P.M. de O. } \\
\text { Soldado do } 6^{\circ} \text { R.I. }\end{array}$ & Homicídio culposo & 1 ano, 9 meses e 10 dias \\
\hline $\begin{array}{l}\text { A. C. de O. } \\
\text { Soldado do } 6^{\circ} \text { R.I. }\end{array}$ & Agressão a superior e embriaguez & 5 anos e 1 mês \\
\hline $\begin{array}{c}\text { J.F.V. } \\
\text { Soldado do Depósito da FEB }\end{array}$ & Deserção & Absolvido \\
\hline $\begin{array}{c}\text { A. } \text { de F. } \\
\text { J. M. } \\
\text { J. A. C. } \\
\text { Soldados do I/II R.O.C } \\
\text { Autorrebocado }\end{array}$ & Conjunção carnal & $\begin{array}{c}6 \text { anos e } 4 \text { meses } \\
\text { O último foi absolvido. }\end{array}$ \\
\hline $\begin{array}{c}\text { J.A.G } \\
\text { S.B. } \\
\text { Soldados da Cia. do Depósito de } \\
\text { Intendência e }{ }^{\circ} \text { Batalhão do } \\
\text { Pessoal }\end{array}$ & Tentativa de furto & $\begin{array}{c}5 \text { meses e } 10 \text { dias e } 9 \text { meses e } 10 \\
\text { dias, respectivamente }\end{array}$ \\
\hline $\begin{array}{c}\text { I.R. da S. } \\
\text { Soldado do } 1^{\circ} \text { R.I. }\end{array}$ & Lesão corporal culposa & 4 meses \\
\hline $\begin{array}{l}\text { W.B. } \\
\text { Soldado do Depósito de Pessoal }\end{array}$ & Lesão corporal culposa & 3 meses e 16 dias \\
\hline $\begin{array}{c}\text { L.A. } \\
\text { Civil Italiano }\end{array}$ & Lesão corporal culposa & 4 meses \\
\hline $\begin{array}{c}\text { A.T. } \\
\text { Soldado do } 6^{\circ} \text { R.I. }\end{array}$ & Lesão corporal & Absolvido \\
\hline J.L.V. & Desacato a superior & 1 ano, 4 meses e 20 dias \\
\hline
\end{tabular}




\begin{tabular}{|c|c|c|}
\hline Soldado do $1^{\circ}$ R.I. & & \\
\hline $\begin{array}{c}\text { J.L. dos S. } \\
\text { Soldado do II/1º R.O. } \\
\text { Autorrebocado }\end{array}$ & Desacato a superior & 2 anos, 10 meses e 20 dias \\
\hline $\begin{array}{c}\text { R. A. B. } \\
\text { ST do } 6^{\circ} \text { R.I. }\end{array}$ & Peculato & 4 anos e 8 meses \\
\hline $\begin{array}{c}\text { J.G. da S. } \\
\text { Soldado do II/1 R.O. } \\
\text { Autorrebocado }\end{array}$ & Lesão corporal & 4 anos e 8 meses \\
\hline
\end{tabular}

Soldado $2^{\circ}$ Grupo de Artilharia

$\begin{array}{ccc}\text { G.R. } & \text { Lesão corporal e atropelamento de } \\ \text { Soldado do } \mathbf{1}^{\circ} \text { Grupo de } & \text { civil } & 1 \text { ano } \\ \text { Artilharia } & & \\ \text { J.T. } & \text { Furto } & 3 \text { anos, } 10 \text { meses e } 20 \text { dias }\end{array}$

Soldado do Depósito do Pessoal
A. S.

Soldado do Depósito de

Abandono de posto

8 meses

Intendência

M.G. da S. Embriaguez em serviço 2 anos, 1 mês e 10 dias

Soldado do II Grupo de Artilharia

$\begin{array}{ccc}\text { M.F.P } & \text { Insubordinação } & 1 \text { ano, } 4 \text { meses e } 20 \text { dias } \\ \text { Soldado do Depósito do Pessoal } & \end{array}$

C.F.C.R.P

S.S.S.

E.A.G.T. Inobservância do dever militar C.F.: 1 ano e 8 meses.

J.G.

Demais absolvidos

Capitães e Major do $11^{\circ}$

Reg. de Infantaria

P.A. de S.

M.F.- Soldados;

H. do C.- Cabo

A.C.

Conjunção carnal mediante

violência

P.A. de S.: 16 NOS, 1 mês e 10 dias.

A.S.

Desobediência à ordem superior

$2^{\circ}$ Sgt do $6^{\circ}$ R.I.

J.G.A.

Agressão a superior e embriaguez

Deserção

10 meses e 15 dias

Soldado do $6^{\circ}$ B.I.

J.M.

Violência contra superior

1 ano

W. de M.B.

H. do C.: 5 meses e 10 dias.

M.F.: 5 anos.

21 anos

2 meses e 20 dias

10 anos e 2 meses

A.B. de O. Lesão corporal 5 meses e 10 dias

Soldado $1^{\text {a }}$ G.A 


\begin{tabular}{ccc}
\hline A.F. & Insubordinação em presença do & 10 anos \\
Soldado $\mathbf{1}^{\circ}$ R.I. & inimigo & \\
B.C. & Desacato a superior & 1 ano e 8 meses \\
Soldado do $\mathbf{1}^{\circ}$ R.I. & & \\
W.M.R. & & \\
T.J.N. & Lesão corporal & 4 meses e 20 dias para cada um
\end{tabular}

Soldados do Depósito do Pessoal

da FEB

$\begin{array}{ccc}\text { J.B. de O. } & \text { Covardia e inobservância do dever } & 1 \text { ano e } 8 \text { meses } \\ \text { Cap. do Rgt. Sampaio } & \text { militar } & 4 \text { meses } \\ \text { D. do N. } & \text { Desobediência à ordem legal }\end{array}$

Soldado do $6^{\circ}$ R.I.

$\begin{array}{ccc}\text { P.T. } & \text { Lesão corporal } & 3 \text { meses e } 10 \text { dias } \\ \text { Soldado do } 6^{0} \text { R.I. } & \end{array}$

J.G.A.

Soldado da Cia de Intendência da

Peculato 1 ano

1a Aud. Da 1 ${ }^{\text {a }}$ DIE

V.F. de A.P.N.

Violência contra inferior

O CSJM não conheceu por ser

$2^{\circ}$ Ten. Do $6^{\circ}$ R.I. alçada dos Conselhos de Justiça

G.P.

Punição disciplinar

Cabo do II $/ 1^{\circ}$ R.O.Au.

$\begin{array}{ccc}\text { A.V.S } & \begin{array}{c}\text { Acidente com viatura militar, } \\ \text { homicídio culposo }\end{array} & \begin{array}{c}\text { Determina que seja apresentada } \\ \text { denúncia }\end{array} \\ \text { L.G.M } & \text { Explosão de minas, homicídio } & \text { Arquivado }\end{array}$

$1^{\circ}$ Ten. do $6^{\circ}$ Rgt. Sampaio

$$
\text { culposo }
$$

P. de O.E.S. Acidente com viatura militar, Arquivamento dos autos

$1^{\circ}$ Tenente da Cia. de Manutenção

homicídio culposo

L.M. do N. Aplicação de pena disciplinar

Soldado do $1^{\circ}$ B.E.

$\begin{array}{ccc}\text { N. dos S. Soldado da Cia. de } & \text { Furto } & \text { Devolução dos autos à } 1^{\text {a }} \text { Aud. Para } \\ \text { Infantaria da FEB. } & \text { mover ação penal }\end{array}$

M.M.R. Homicídio culposo

Cabo da Cia. de Intendência da $\mathbf{1}^{\mathrm{a}}$

processado

DIE

$\begin{array}{ccc}\begin{array}{c}\text { A. de A.P. } \\ \text { Soldado do } 2^{\circ} \text { Grupo de }\end{array} & \text { Acidente com viatura militar } & \text { Arquivamento dos autos } \\ \text { Artilharia } & & \\ \text { A.C. de A. } & \text { Acidente com viatura militar, } & \text { Arquivamento dos autos } \\ \text { Cabo da Cia A.G. da } \mathbf{1}^{\text {a }} \text { DIE } & \text { homicídio culposo } & \\ \text { L.P. } & \text { Violência carnal } & \text { Arquivamento dos autos } \\ \text { (Italiana vítima) } & & \\ \text { C.I. de L.C. } & \text { Acidente com viatura militar } & \text { Arquivamento dos autos }\end{array}$

Cabo do $2^{\circ}$ Grupo de Artilharia 


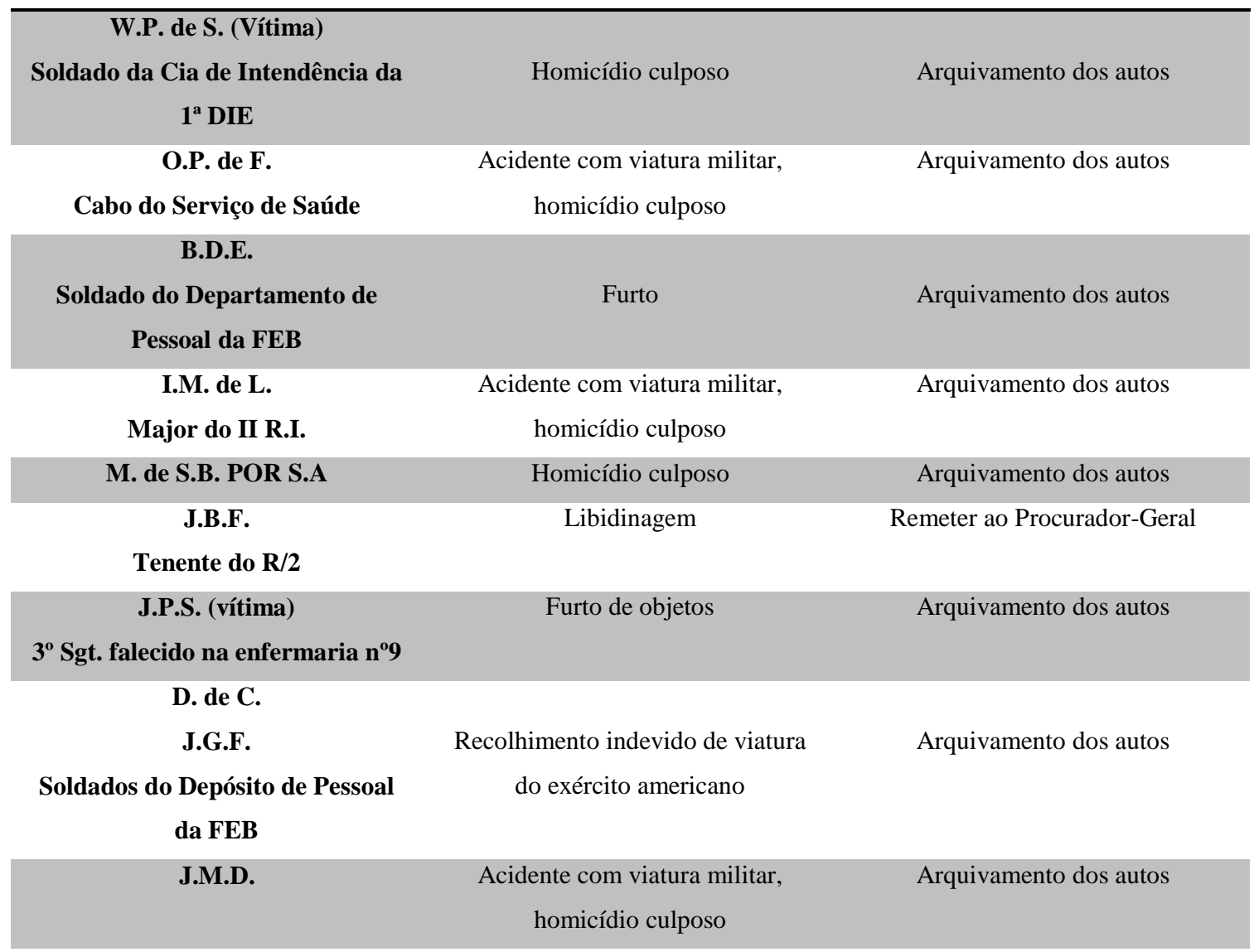

H.V. da C.R.

A.P.,

A.V e

Arquivamento dos autos

M.A. da S.

Soldados do Departamento de

Pessoal

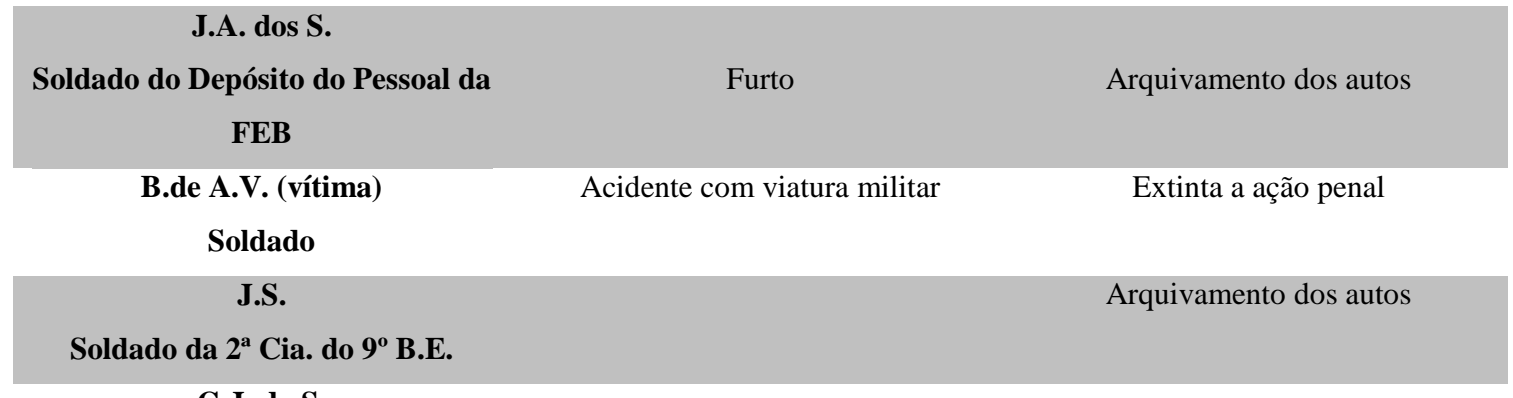

G.J. da S.

M. de S.A.L.

L.A de $O$.

Fuga

Arquivamento dos autos

Soldados do Departamento de 
Julgadores:

Gen. Heitor Augusto Borges- Presidente (nova presidência)

Gen. Washington Vaz de Melo

Gen. Francisco de Paula Cidade

Gen. Waldomiro Gomes Ferreira- Procurador-Geral

\begin{tabular}{|c|c|c|}
\hline ENVOLVIDO & DELITO IMPUTADO & PENA \\
\hline $\begin{array}{c}\text { A.G.C. } \\
\text { Soldado do } 1^{\circ} \text { batalhão de Saúde }\end{array}$ & Desacato a superior & $\begin{array}{l}\text { Ação Penal extinta pelo suicídio } \\
\text { do acusado }\end{array}$ \\
\hline $\begin{array}{c}\text { O.F.R } \\
\text { Soldado do } 6^{\circ} \text { R.I. }\end{array}$ & Furto & Absolvido \\
\hline M.M.M. & Desacato a superior & $\begin{array}{l}\text { Absolvido no Art. } 154 \text { do CPM. } \\
\text { Condenado a } 1 \text { ano e } 8 \text { meses no } \\
\text { art. } 225 \text { do CPM. }\end{array}$ \\
\hline $\begin{array}{c}\text { O.R.V.F. } \\
2^{\circ} \text { Sargento da F.A.B. }\end{array}$ & Apropriação indébita & 10 meses e 20 dias \\
\hline $\begin{array}{c}\text { R.M. de C. } \\
2^{o} \text { Ten. do } 6^{\circ} \text { R.I. }\end{array}$ & $\begin{array}{l}\text { Descumprimento do dever militar. } \\
\text { Temor em presença do inimigo }\end{array}$ & 1 ano \\
\hline W.M. da S. & Violência contra superior & 1 ano \\
\hline $\begin{array}{c}\text { H.S. } \\
\text { J.G.A. } \\
\text { G.F. } \\
\text { Soldados do Serviço de Saúde }\end{array}$ & $\begin{array}{c}\text { Desobediência à ordem de } \\
\text { sentinela }\end{array}$ & $\begin{array}{l}\text { O primeiro indiciado, condenado a } \\
9 \text { meses e } 10 \text { dias. O segundo e o } \\
\text { terceiro, absolvidos. }\end{array}$ \\
\hline $\begin{array}{c}\text { V. dos S. S. P. } \\
\text { Soldado do } 1^{\circ} \text { R.I. }\end{array}$ & Lesão Corporal & 8 meses \\
\hline $\begin{array}{c}\text { A.F. } \\
\text { M.H. da S. } \\
\text { J.T.C. } \\
\text { Soldados do IV G.A. }\end{array}$ & $\begin{array}{c}\text { Conjunção carnal mediante } \\
\text { violência }\end{array}$ & 7 anos e 6 meses \\
\hline O. da C.B. & Desrespeito a superior & 1 ano \\
\hline
\end{tabular}

Cabo do $1^{\circ}$ R.I.

\begin{tabular}{|ccc|}
\hline F.M.J. & Abandono de posto & 1 ano e 8 meses \\
A.J.D. & Insubordinação & 1 ano e 6 meses \\
Soldado do 11 R.I. & & \\
A. dos S. & Deserção & 1 ano e 6 meses \\
Soldado do $\mathbf{1 1}^{\circ}$ R.I. & & \\
W.P. dos S. & Deserção & Absolvido
\end{tabular}

Soldado do Depósito de Pessoal

B.M. Lesão corporal 1 ano

Soldado do $6^{\circ}$ R.I.

J.M.

S. da C.M. 


\begin{tabular}{|c|c|c|}
\hline $\begin{array}{c}\text { M.C. } \\
\text { S.A } \\
\text { Soldados do } 11^{\circ} \text { R.I. e D.P } \\
\text { Da FEB }\end{array}$ & Conjunção carnal & $\begin{array}{c}2 \text { anos, } 2 \text { meses e } 20 \text { dias para o } \\
\text { primeiro indiciado e absolvição } \\
\text { para os demais }\end{array}$ \\
\hline $\begin{array}{c}\text { J.A. } \\
\text { Soldado do } 6^{\circ} \text { R.I. }\end{array}$ & Desacato a superior & 1 ano e 6 meses \\
\hline $\begin{array}{c}\text { L.B.S. } \\
\text { Soldado do } 6^{\circ} \text { R.I. }\end{array}$ & Lesão corporal & 2 anos e 10 dias \\
\hline $\begin{array}{c}\text { M.M.G. } \\
2^{\circ} \text { Sgt do Grupo de Artilharia }\end{array}$ & Homicídio culposo & Absolvido \\
\hline $\begin{array}{l}\text { D.C. } \\
\text { Soldado do Depósito de Pessoal } \\
\text { da FEB }\end{array}$ & Homicídio doloso & 8 anos e 8 meses \\
\hline $\begin{array}{c}\text { P.C.L.A. } \\
\text { Soldado do } 11^{\circ} \text { R.I. }\end{array}$ & Conjunção Carnal & 5 anos e 6 meses \\
\hline $\begin{array}{c}\text { W.P. } \\
\text { A.F.G } \\
\text { J.A. dos S. } \\
\text { Soldados do Depósito de Pessoal } \\
\text { da FEB } \\
\text { A. dos S. } \\
\text { Soldado do Regimento } \\
\text { Sampaio }\end{array}$ & Insubordinação & 1 ano, 4 meses e 10 dias \\
\hline $\begin{array}{c}\text { I.P. de S. } \\
\text { Soldado do Depósito de Pessoal } \\
\text { da FEB }\end{array}$ & Lesão corporal & 8 meses \\
\hline $\begin{array}{c}\text { J. de O.S } \\
\text { Soldado do } 11^{\circ} \text { R.I. }\end{array}$ & Desobediência à ordem legal & 2 meses e 20 dias \\
\hline $\begin{array}{c}\text { A.P.S. } \\
\text { Soldado do } 11^{\circ} \text { R.I. }\end{array}$ & Desobediência à ordem legal & 2 meses e 20 dias \\
\hline $\begin{array}{c}\text { B. de P.C.S. } \\
\text { Soldado do } 6^{\circ} \text { R.I. }\end{array}$ & Libidinagem & 9 anos e 4 meses \\
\hline $\begin{array}{l}\text { J.M.V. } \\
\text { Soldado do Depósito de Pessoal } \\
\text { da FEB }\end{array}$ & Uso indevido de insígnia & 8 meses \\
\hline $\begin{array}{l}\text { B.C. } \\
\text { Soldado do Depósito de Pessoal } \\
\text { da FEB }\end{array}$ & Desacato à superior & 2 anos, 2 meses e 20 dias \\
\hline $\begin{array}{c}\text { C.G. } \\
\text { Soldado do } 11^{\circ} \text { R.I. }\end{array}$ & Lesão corporal & 2 meses e 15 dias \\
\hline $\begin{array}{c}\text { I. da S. } \\
\text { Soldado do Depósito de } \\
\text { Pessoal da FEB }\end{array}$ & Furto & 1 ano e 4 meses \\
\hline O.S. & Desobediência à ordem legal & Absolvido \\
\hline
\end{tabular}




\begin{tabular}{|c|c|c|}
\hline Cabo do $11^{\circ}$ R.I & & \\
\hline $\begin{array}{c}\text { J. dos S. } \\
\text { Soldado do Depósito de } \\
\text { Intendência }\end{array}$ & Desobediência à ordem legal & Absolvido \\
\hline $\begin{array}{l}\text { A.U.A. } \\
\text { Soldado do Depósito de Pessoal } \\
\text { da FEB }\end{array}$ & Lesão corporal & 8 meses \\
\hline $\begin{array}{c}\text { J. da C.N. } \\
\text { Soldado da Cia do QG da } \mathbf{1}^{\mathrm{a}} \\
\text { DIE }\end{array}$ & Lesão corporal, embriaguez & 2 anos \\
\hline $\begin{array}{c}\text { R.P. } \\
\text { Soldado do } 11^{\circ} \text { R.I. }\end{array}$ & Furto & 1 ano, 5 meses e 10 dias \\
\hline $\begin{array}{l}\text { M. de S. } \\
\text { Soldado do Depósito de Pessoal } \\
\text { da FEB }\end{array}$ & Deserção & 7 meses \\
\hline $\begin{array}{l}\text { M. de S. } \\
\text { Soldado do Depósito de Pessoal } \\
\text { da FEB }\end{array}$ & Deserção & 10 meses e 15 dias \\
\hline $\begin{array}{c}\text { G.F. da S. } \\
\text { Soldado do } 11^{\circ} \text { R.I. }\end{array}$ & Homicídio culposo & 1 ano, 8 meses e 6 dias \\
\hline $\begin{array}{c}\text { M. dos S. } \\
\text { Soldado do Batalhão de Saúde }\end{array}$ & Abandono de posto & 17 meses e 20 dias \\
\hline $\begin{array}{c}\text { G.F. de } \mathrm{O} . \\
\text { Cabo do } 11^{\circ} \text { R.I. }\end{array}$ & Lesão corporal & 1 ano \\
\hline $\begin{array}{c}\text { L. de C. } \\
\text { A.R. de O. } \\
\text { W.C } \\
\text { Soldados do } 11^{\circ} \text { R.O.A.R }\end{array}$ & Desobediência à ordem legal & 9 meses \\
\hline $\begin{array}{c}\text { J. de O.L. } \\
\text { S.de A. } \\
\text { Soldados do } 9^{\circ} \text { B.E }\end{array}$ & Insubordinação & 17 meses e 10 dias \\
\hline $\begin{array}{c}\text { M. de J.K. } \\
\text { Soldado do } 6^{\circ} \text { R.I. }\end{array}$ & Desacato a superior & 1 ano, 1 mês e 15 dias \\
\hline $\begin{array}{c}\text { C.A. da P. } \\
\text { Soldado do Batalhão de Saúde }\end{array}$ & Lesão Corporal & 10 meses e 20 dias \\
\hline $\begin{array}{c}\text { P.P.M. } \\
\text { Soldado do } 3^{\circ} \text { G.A. }\end{array}$ & Homicídio & Absolvido \\
\hline $\begin{array}{c}\text { A.A. de A. } \\
\text { Soldado do } 6^{\circ} \text { R.I. }\end{array}$ & Homicídio culposo & 1 ano, 5 meses e 10 dias \\
\hline $\begin{array}{c}\text { J.T. de } O . \\
\text { Soldado do } 1^{\circ} \text { R.I. }\end{array}$ & Desobediência à ordem legal & 5 meses e 28 dias \\
\hline R.P. de S. & Desobediência à ordem legal & 4 meses e 28 dias \\
\hline J. de A. & Desacato a superior e agressão & 1 ano, 7 meses e 15 dias \\
\hline R.G. de O. & Lesão corporal & 4 meses e 4 dias \\
\hline
\end{tabular}




\begin{tabular}{|ccc|}
\hline Soldado da 9 $^{\text {a Cia do DP da FEB }}$ & Furto & 10 meses e 20 dias \\
N. dos S. & & \\
Soldado da Cia. de Intendência & & 1 ano, 4 meses e 10 dias \\
A.V. & Lesão corporal & \\
Soldado do Depósito do Pessoal \\
da FEB
\end{tabular}

D.B.A. (italiano)

Civil, motorista do D. Furto 10 meses e 20 dias

Intendência
A.J. da S.
O $1^{\circ}: 1$ ano, 5 meses e 6 dias.

A.O

O $2^{\circ}: 1$ ano, 3 meses e 12 dias.

A.G.G.C.

Furto

O $3^{\circ}: 1$ ano, 11 meses e 16 dias.

M.H.

O $4^{\circ}: 1$ ano, 4 meses e 26 dias.

J.A.

O 5 : 1 ano, 4 meses e 13 dias.

J.E. dos S.

Deserção no momento de partida

6 meses

Soldado do Rgt. Sampaio

da Unidade

\begin{tabular}{|c|c|c|}
\hline $\begin{array}{l}\text { N.C. } \\
\text { Soldado do Batalhão de Saúde }\end{array}$ & Deserção & 6 meses \\
\hline $\begin{array}{c}\text { J.F. da S. } \\
2^{\circ} \text { Sgt. do Serviço de Saúde }\end{array}$ & Apropriação indébita e falsidade & 1 ano, 4 meses e 20 dias \\
\hline $\begin{array}{l}\text { J.R.P. } \\
\text { Soldado do Dep. de Pessoal da } \\
\text { FEB }\end{array}$ & & Arquivamento dos autos \\
\hline
\end{tabular}

\section{J.H. de A.G.}

Soldado do Dep. de Pessoal da Deserção em presença do inimigo 21 anos

FEB

$\begin{array}{ccc}\begin{array}{c}\text { R.S (italiano) } \\ \text { Civil, posto regulador de } \\ \text { Livorno }\end{array} & \text { Homicídio culposo } & 1 \text { ano e } 4 \text { meses } \\ \text { M.M.P. } & \text { Homicídio culposo } & 1 \text { ano e } 4 \text { meses }\end{array}$

Cabo da Cia. de Intendência

R.P. de M.

$3^{\circ}$ Sgt. do Dep. de Pessoal da

Furto

Punição disciplinar

FEB

O.G.L.
A.R. $\operatorname{dos} \mathrm{S}$.
Furto
Indultado

Sgt. e soldado do Depósito de

Pessoal
P.G.
Incompetência da Justiça Militar
P.U.
para julgar os fatos

Civis Italianos

O.P. Furto e apropriação indébita Arquivamento dos autos

$2^{\circ}$ Ten. da Cia. de Manutenção 


\begin{tabular}{|c|c|c|}
\hline $\begin{array}{c}\text { Furto havido na Companhia de } \\
\text { Comando do Departamento de } \\
\text { Pessoal }\end{array}$ & Furto & Arquivamento dos autos \\
\hline $\begin{array}{c}\text { Grupo de soldados da FEB } \\
\text { IPM procedido pela Tenenza Di } \\
\text { Napoli Arenaccia }\end{array}$ & Homicídio & Arquivamento dos autos \\
\hline $\begin{array}{c}\text { J.L.V. } \\
\text { Soldado do Rgt. Sampaio }\end{array}$ & Desacato a superior & 1 ano, 4 meses e 20 dias \\
\hline $\begin{array}{c}\text { P.P. (vítima) } \\
\text { Soldado do } 11^{\circ} \text { R.I. }\end{array}$ & Homicídio & Arquivamento \\
\hline $\begin{array}{c}\text { A.A. de A. } \\
\text { Soldado da Bateria de Comando } \\
\text { do I Grupo de Obuses }\end{array}$ & Lesão corporal & 1 ano \\
\hline $\begin{array}{c}\text { A.M. dos S. } \\
\text { Soldado do Departamento do } \\
\text { Pessoal da FEB }\end{array}$ & Lesão Corporal & Extinta a punibilidade \\
\hline $\begin{array}{c}\text { P.T. dos R. } \\
\text { Soldado do II/1 }{ }^{\circ} \text { R.O. Au. }\end{array}$ & Violência contra superior & 2 anos e 8 meses \\
\hline
\end{tabular}

Nada obstante, em que pese todo trabalho desempenhado pela Justiça Expedicionária, em dezembro de 1945, o Executivo Federal, por meio de decreto, resolveu indultar a todos os oficiais e praças que, como integrantes da FEB, houvessem cometido crimes, que não de homicídio doloso ou deserção perante os inimigos. Os que não foram alcançados pelo indulto tiveram suas penas comutadas, a posteriori.

Acerca da atuação da Justiça Militar em tempo de guerra, merece registro a opinião do General Francisco de Paula Cidade, integrante do CSJM anteriormente qualificado. Na opinião do General, o inquérito policial militar nada mais era que uma "peça inútil e, em campanha, uma fonte de imperfeições"--, por macular o processo -"que por ele se inicia com vícios fundamentais"--.

Em seu sentir, o problema decorreria, basicamente, da falta de conhecimentos especializados dos oficiais encarregados dos inquéritos policial-militares, tanto no que diz respeito ao direito penal e processual penal militar quanto em razão do desconhecimento das técnicas policiais, além do fato de não se ocuparem exclusivamente dos inquéritos, tendo que acumular a função de encarregado com outras missões relacionadas à guerra.

Embora reconhecendo que o serviço da justiça pretere a qualquer outro, o General assinalou, realisticamente, que -“na guerra, por uma exigência do próprio instinto de conservação, o dever de vencer ou, pelo menos, de enfrentar o inimigo, prima sobre todos os outros"--. Por tais razões, asseverava -“não tenho dúvidas sobre a 
possibilidade de muitos delinquentes não chegarem à barra dos tribunais pelo fato dos inquéritos nunca terem chegado às mãos dos auditores"-- 262 .

Em sentido diverso, o comandante da FEB, João Batista Mascarenhas de Morais, definiu a importância da Justiça na guerra no sentido de que:

\begin{abstract}
“(...) mesmo no quadro tormentoso da guerra, que é o recurso extremo e violento a que lançam mãos os homens para a solução dos conflitos internacionais, não se travariam combates e batalhas, e sim choques e encontros desordenados entre as facções ou hostes desenfreadas, se os exércitos em luta não se movessem dentro dos limites demarcados pelas regras e princípios regulamentares e os soldados individualmente não se submetessem à autoridade soberana da Lei." 263
\end{abstract}

Ressaltou, ainda, que o trabalho da Justiça Militar concorreu "eficientemente" para que os elos da disciplina não se partissem e não se quebrasse a coesão moral da tropa que o Brasil havia enviado ao continente europeu, --“como legítima expressão de seu poder militar"--.

Analisando a atuação da Justiça Militar da FEB, o ex-pracinha Joaquim Xavier da Silveira nos apresenta o dado estatístico de que a maioria dos delitos foi praticada por pessoal do contingente da tropa em serviço de retaguarda ou depósito (em clara divergência à César Maximiano, que afirma o contrário ${ }^{264}$ ).

Dois aspectos da atuação da Justiça Expedicionária Brasileira chamam a atenção por sua gravidade, quer quanto as consequências para as operações militares, quer quanto à sua gravidade jurídica: (i) as citadas deserções julgadas durante a campanha e; (ii) a condenação à pena de morte a dois militares, pela prática de violência carnal e homicídio a familiar da vítima, a fim de garantir a execução do delito sexual.

Em que pese o número de delitos praticados em combate ter sido reduzido ${ }^{265}$, se comparado às demais tropas que tomaram parte no teatro de guerra europeu da $2^{\mathrm{a}}$ Guerra Mundial, o crime de deserção ${ }^{266}$ foi, de longe, o mais cometido durante a guerra,

\footnotetext{
${ }^{262}$ Idem. É notável como tal situação vivenciada na campanha italiana ainda seja vivenciada atualmente. De fato, não é raro que a deficiente condução de um inquérito policial-militar provocada, na maioria das vezes, pelo despreparo jurídico de seu encarregado somado a uma gama de atribuições das quais precisa se desincumbir concomitantemente cause inúmeros óbices à ação penal, impossibilitando muitas vezes uma solução adequada ao caso investigado.

${ }^{263}$ Nota de Comando, datada de 20 de abril de 1945 in: MASCARENHAS DE MORAES, João Baptista. A FEB pelo seu Comandante. Rio de Janeiro: Biblioteca do Exército Ed., 2005.

${ }^{264}$ A $1^{\text {a }}$ Auditoria da DIA registrou trinta julgamentos com elementos do Depósito de Pessoal para 66 com os demais órgãos divisionários. A $2^{\text {a }}$ Auditoria julgou 133 militares da FEB, dos quais 38 eram do Depósito de Pessoal. Grosso modo, o Depósito constituía 40\% do efetivo total da expedição. Albuquerque, p. 622, 628 e 629. Fonte: MAXIMIANO, p. 371.

${ }^{265}$ SILVEIRA, Joaquim Xavier. A FEB por um soldado. Rio de Janeiro: Biblioteca do Exército, 2001. p. 110.

266 "Durante algum tempo houve uma opinião generalizada de que deserção perante o inimigo não teria ocorrido, nenhum militar entregou-se voluntariamente ao inimigo. Sobre esta matéria não há referência precisa da FEB. No entanto houve. Em um desses casos, um soldado filho de alemães entregou-se voluntariamente ao inimigo. O assunto é
} 
sendo seguido pelas lesões corporais e homicídios culposos praticados, geralmente, na condução de veículos automotores e no manuseio imprudente de armamento.

Em verdade, os casos de deserção, em número de 34, foram desclassificados em sua maioria, pois não eram propriamente deserções, mas desobediências aos prazos de licença, dispensa do serviço e prorrogação de passeios, chamados na gíria de tocha, e não decorriam de fuga ao combate ou ao embate para o qual foram selecionados. Eram, tão somente, transgressões disciplinares. De se destacar também, as “deserções às avessas", decorrentes de expedicionários que, evacuados do front, fugiam de suas lotações nos órgãos de retaguarda em direção à linha de frente, na ânsia de permanecer junto aos companheiros, burlando a burocracia militar.

Em tempos de guerra, é cediço que as punições são mais severas, assim como a tipificação dos crimes é, também, muito específica. Covardia, traição, deserção em presença de inimigo, todos constantes da Segunda Parte do Código Penal Militar, estabeleciam penas que poderiam chegar a 20 anos de reclusão ou à morte. Segundo o General Francisco de Paula Cidade, que compunha o Conselho Supremo Militar, --“são as contingências da guerra e não as más entranhas dos juízes que ditam as sentenças mais severas..."--.

Partindo dessa premissa, introduz-se o segundo aspecto que atraiu a atenção do autor: uma sentença da Justiça Militar foi proferida no sentido da impor a pena de morte a dois soldados brasileiros.

Em breve síntese do fato que será pormenorizado no capitulo que se segue, dois soldados do QG de Retaguarda invadiram uma residência civil, violentaram uma jovem italiana e mataram um parente seu, civil, que tentava impedir o crime. Esse fato causou indignação não comando e na tropa, na medida em que havia um algum nível de entendimento entre italianos e brasileiros, o qual restou violado por esses pracinhas que mancharam a farda brasileira. Segundo Joaquim Xavier da Silveira, --“a população civil

\footnotetext{
tratado pelo próprio Comandante Marechal Mascarenhas, que na $2^{\text {a }}$ edição de seu primeiro livro, 'A Feb pelo seu Comandante', comenta: "Houve um único caso de deserção, o do soldado B.L., que não mais foi reincluído na FEB, suicidando-se no Acampamento de Luchy Steik, em Saint-Valéry, França, onde foi inumado. Esse triste episódio deve ser levado a débito da deficiência no processo de seleção do contingente da FEB, pois não deveria ser indicado para a função de combatente um descendente direto de alemães que certamente, durante sua infância e juventude, sofreu forte influência de seus pais. É notória a decisão norte-americana, de não enviar para o Teatro de Operações do Pacífico nenhum descendente de japonês, os chamados nisseis foram todos servir no Teatro da Europa. Esses nisseis, como cidadãos americanos, combateram com extrema bravura, tendo uma dessas unidades compostas de nisseis o famoso "100 Battalion", sido das mais condecoradas Unidades do Exército americano na Europa por excepcional bravura". Fonte: Idem, p. 110.
} 
não olhava os brasileiros como tropa de ocupação e sim combatentes pela liberdade"-267.

Em que pese o violento e injustificado crime ter sido sentenciado com a pena capital, o fuzilamento não foi executado. Restarão doravante explicitados todos os pormenores que permeiam as circunstâncias fáticas desse destacado caso, singular em sua condenação à pena de morte, depois de proclamada a República no Brasil.

\section{IV. - CONDENAÇÃO À MORTE: O CASO MARGELLI.}

\section{(i) Relato dos acontecimentos.}

$\mathrm{Na}$ atualidade, passados mais de sete décadas do fim da Segunda Guerra Mundial, ainda faz parte da memória e da identidade do povo brasileiro a participação da FEB na Itália. Primeira, e até hoje única força de combate latino-americana a lutar em solo europeu, a memória da FEB está relacionada ao engajamento de brasileiros simples, a maioria deles saídos dos campos de um país ainda prioritariamente agrário, para combater no maior conflito da história da humanidade.

Contudo, a participação das Forças Armadas na Segunda Guerra Mundial não fica restrita às ações de combate dos pracinhas na Itália. A experiência foi mais além. Nesse sentido, convém trazer à lume fatos e experiências executadas por soldados brasileiros que se configuraram em crimes, manchas na farda da FEB que restaram processadas e julgadas pela Justiça Militar Expedicionária Brasileira:

\footnotetext{
“(...) o silencio fácil e sem riscos, a conspiração do silêncio, que ninguém ousa quebrar, pode tornar-se criminosa, quando se cala sobre erros cometidos, quando não ousa expor as deficiências observadas. Criminosas, não somente porque se estará, assim, preparando o caminho para repetições destes erros, de nada valendo o sacrifício daqueles que, por casa deles, sofreram uma vez, como sobretudo- tendo tido, como teve, grande parte da nação, um conhecimento dessas falhas, de uma forma, muitas vezes, intencionalmente errônea, parcial ou exagerada- o silêncio relativo a tudo o que se passou, vem, também, criar em torno das autoridades e das suas afirmações, unilateralmente apologéticas, uma atmosfera de falsa confiança, de farisaísmo, consciente, de convencional verniz oficial, que soa falso e que ninguém leva a sério ${ }^{268}$."
}

É partindo desta citação, retirada de uma obra oficial de combatentes que presenciaram as mazelas e os horrores que o homem provoca em guerra, que se propõe a

\footnotetext{
${ }^{267}$ Idem.

${ }^{268}$ Depoimentos de Oficiais da Reserva sobre a FEB. São Paulo: IPÊ, 1950. p.14 e 15.
} 
elucidar os delitos de violência carnal $^{269}$ e homicídio ${ }^{270}$ cometido por dois soldados integrantes da Força Expedicionária Brasileira, durante a campanha na Itália.

Conforme exposto em capítulos anteriores, no ano de 1942, em meio ao torpedeamento de navios na costa brasileira por parte de submarinos alemães, gerando morte e sofrimento, fez com que o povo apoiasse a ida de uma Força Expedicionária à Europa lutar contra os nazifascistas.

Homens e mulheres de várias partes do país foram convocados e aceitaram o compromisso de envergar o uniforme do Exército Brasileiro a fim de ombrear-se com outras nações aliadas pelo fim do conflito.

Muitos jovens, que sequer conheciam algo além da vila mais próxima da fazenda em que viviam com seus familiares, que utilizavam a enxada como instrumento de trabalho e o chapéu de palha para se protegerem do sol, foram deslocados para outros centros, onde existiam sotaques e outros pensamentos. Lá, vislumbraram novos horizontes, receberam o fuzil para realizar o seu novo ofício e colocaram o capacete de aço na cabeça.

Essa situação, extremamente comum dentro das fileiras da FEB, se repetiu com Adão Damasceno Paz (“A.D.P”), 26 anos, e Luís Bernardo de Morais (“L.B. de M.”), 21 anos, agricultores oriundos das regiões rurais de Santiago e São Borja/RS. Após serem convocados, seguiram ao Rio de Janeiro, então capital do país, onde iniciaram um forte e pesado treinamento, aguardando o momento de embarcarem para além mar. Nos momentos de folga, os dois rapazes aproveitavam para conhecer as belezas e o mundo novo que existia na já então Cidade Maravilhosa.

Em 02 de julho do ano de 1944, Adão e Luís estavam em um enorme navio como membros do primeiro escalão da FEB e junto deles, milhares de pracinhas advindos de diversas partes do país.

Não foi possível encontrar registros que confirmassem a hipótese de os dois agricultores terem se conhecido ainda em seu Estado de origem (Rio Grande do Sul), dada a proximidade de suas cidades e a semelhança dos ofícios desempenhados; no campo de treinamento no Rio de Janeiro; ou ainda no navio de transporte americano que os levou á Itália. Contudo, ao chegarem ao "país da bota", tendo adentrado por Nápoles aos 16 de julho de 1944, constam em suas fichas funcionais terem sido lotados no Pelotão de Defesa

\footnotetext{
${ }^{269}$ Art. 192, do Código Penal Militar de 1944: Constranger mulher a conjunção carnal, mediante violência ou grave ameaça. Pena- reclusão, de três a oito anos.

${ }^{270}$ Art. 181, do CPM/44. Matar alguém: $2^{\circ}$. Se o homicídio é cometido: V- para assegurar a execução, ocultação, a impunidade ou vantagem de outro crime. Pena- reclusão, de doze a trinta anos.
} 
do Quartel General (QG), compondo a guarda pessoal do comandante da $1^{\text {a }}$ Divisão de Infantaria da Força Expedicionária Brasileira, o general João Batista Mascarenhas de Morais. Decerto, trabalhar na proteção do General não era tarefa fácil, uma vez que estava sempre em deslocamento por toda área de atuação da FEB no norte da Itália.

Dados os constantes deslocamentos do Comandante da FEB, coube aos rapazes, durante meses, acompanhar o General Mascarenhas em suas viagens à linha de frente, o que lhes parecia muito fatigante, pois -"o general não parava"— (Luís Bernardo de Morais à "Revista da Semana", de 16 de julho de 1949).

Contudo, após quatro meses em solo italiano, Adão Damasceno e Luís Bernardo sucumbiram aos seus instintos mais baixos, em violação à ética e pundonor militar, a fim de incorrerem em um dos crimes mais bárbaros perpetrados por pracinhas no teatro de combate da Itália, consoante a visão da própria Justiça Militar da FEB, que houve por bem aplicar-lhes a sentença mais severa: condenação à pena capital.

O crime em questão ocorreu no dia nove de janeiro do ano de 1945, na pequena aldeia medieval de Madognana, Comune de Franaglione, província da Bolonha, região italiana da Emilia-Romagna, nordeste da Itália e não muito distante da cidade de Porretta-Terme onde estava localizado o QG. Segundo consta nos autos do processo analisado, bem como no Boletim do Exército no 13, de 31 de março de 1945, às fls. 948/953, os soldados do Pelotão de Defesa do Quartel General do $1^{\circ}$ DIE, Adão Damasceno e Luís Bernardo, mediante ameaça e uso de violência, forçaram a menor Giovanna Margelli, virgem e com 15 anos de idade, à prática de conjunção carnal. Para assegurar a execução deste delito, um deles, Luís Bernardo, matou com uma rajada de metralhadora, o tio de Margelli, Leonardo Vivarelli.

Através da análise mais aprofundada do caso $^{271}$, verificou-se que o iter criminis (sucessão dos vários atos que devem ser praticados para atingir o fim desejado) se desenvolveu a partir do momento em que aqueles dois soldados avistaram a vítima, Giovanna Margelli, por volta das 16 horas, enquanto passeava acompanhada de Vittoria Mendola. Os pracinhas seguiram ambas até a casa em que Giovanna estava hospedada. Adentrando, se depararam com a avó de Giovana, Maria Rita; sua prima Tonina, de 23 anos; e uma criança de três anos de idade, Ferdinando, filho de Tonina.

\footnotetext{
${ }^{271}$ Os relatos a seguir expostos neste capítulo foram possíveis através de consulta à fonte histórica primária: Autos da Apelação ${ }^{\circ}$ 21-1945, cuja cópia do arquivo em formato pdf foi gentilmente cedida pelo Setor de Arquivos Históricos do Supremo Tribunal Militar (“STM”) em Brasília/DF.
} 
Inicialmente se limitaram a agradar as pessoas que ali estavam, oferecendo um pedaço de chocolate e dirigindo algumas poucas palavras, declarando aos presentes que não tivessem medo, -- "pois os brasileiros eram bons"--. Fizeram mais alguns comentários e se retiraram, afirmando que iriam entrar em serviço.

No quartel general, os soldados jantaram e armaram-se, cada um com uma metralhadora portátil, voltando à casa onde já haviam estado à tarde, à procura de uma mulher, que segundo informaram, lhes "tinha feito cara feia". Às $20 \mathrm{~h} 30$ do dia 09 de janeiro de 1945, noite de inverno rigoroso na Itália, retornaram à casa onde haviam estado mais cedo, -- "movidos por intuitos que não deveriam ser de natureza nobre"--, pois seguiram para o seu intento utilizando o chamado --"passa montanha"--, gorro com abertura apenas nos olhos.

Lá chegando, encontraram Giovana; sua prima Tonina e seu filho Ferdinando; os primos Stefano, de 20, e Giuseppe, de 14; e a avó doente, Maria Rita. Avistando-os, novamente, os moradores os convidaram a entrar e aquecer-se junto ao fogo, talvez esperançosos de receber alguma migalha que lhes mitigasse a fome.

Em seguida, Adão Damasceno disse a Luís Bernardo que era melhor apagar a luz de uma lamparina a querosene, dizendo-_"Vamos apagar a luz de uma vez para pegar a mulher (Giovanna Margelli) no escuro"--. Consta no Boletim do Exército que Luís repetiu a ordem de apagar a luz para Stefano, mas o rapaz não entendeu. O soldado da FEB, então, deu uma rajada de metralhadora que destruiu a lamparina, apagando a luz e instaurando o pânico nos presentes, que fugiam como podiam. Em seus depoimentos, os soldados disseram que, à exceção de Giovanna, todos fugiram.

O jovem Giuseppe, primo de Giovana, deu outra versão. Relatou que foi trancado no banheiro por Luiz Bernardo e, depois empurrado a um quarto, de onde foi obrigado a pular da janela. O soldado teria, ainda, disparado em sua direção, sem acertálo.

Nesse interregno, Adão teria se atirado sobre Giovana, levando-a para um quarto com a finalidade de violenta-la e saciar seus "instintos carnais". A fim de facilitar a consumação do delito, Luís se colocou de guarda na porta de entrada da casa, o que lhe permitia ficar de olho no movimento de fora do recinto.

É ponto pacífico, atestam os relatos, que Adão agarrou Giovanna. Ela pediu socorro a Stefano, que alegou nada ter feito por estar desarmado. Provavelmente alertado pelos disparos e pelo terror transmitido pelos que fugiram atemorizados, Leonardo Vivarelli, 57 anos, tio da vítima, veio em seu auxílio e tentou adentrar no recinto, 
desarmado. Para seu azar, foi visto pelo soldado brasileiro, que não pestanejou e disparou uma rajada de balas que o atingiram no pescoço e no ouvido, levando-o a óbito no próprio local. Após o assassinato, Luís Bernardo gritou a seu colega -“Apressa-te (Adão) que já matei um homem"--.

Stefano sustentou versão semelhante. Afirmou que ouviu o soldado gritar -“Andare via (vá embora)!"--. Após uns segundos, ouviu a descarga de metralhadora. Depois, o silêncio.

Em meio à confusão, os soldados inverteram os papéis. Adão, finalizando a violação, trocou de posição com seu companheiro. Assim, Luiz Bernardo seguiu para o quarto com a menor, onde passou cerca de 30 minutos, mas se sentiu impossibilitado de realizar o ato sexual, atribuindo isto ao suposto estado de embriaguez em que se encontrava. Contudo, ao sair do quarto da menor, relatou ao seu companheiro que consumara o ato e a havia violentado.

A verdade real dos fatos, contudo, restou admitida em depoimento pelo próprio Luís, confirmada pela vítima e pela junta médica da FEB: Luís de Moraes não praticou o ato. Mentiu por “amor-próprio", conforme ressaltado na investigação do caso.

Findo os trabalhos, os soldados retornaram rapidamente ao acampamento de sua unidade, pois estavam escalados para entrarem de serviço, ainda naquela noite. Na saída de Madognana, Luiz Bernardo deixou cair um cachecol e uma lanterna, que foram encontrados por um dos primos de Giovana, Stefano, ao seguir a dupla.

No dia seguinte, 10 de janeiro de 1945, o irmão do falecido Leonardo Vivarelli foi ao encontro da Polícia da FEB a fim de prestar queixa dos crimes praticados, entregando no Quartel-General da $1^{\mathrm{a}}$ Divisão de Infantaria Expedicionária (“DIE”), em Porreta Terme, cidade cercada por montanhas controladas pelo exército nazista, os materiais encontrados por Stefano.

Detidos, os soldados confessaram seus crimes. Suas confissões conferiam com os depoimentos prestados pelas testemunhas ouvidas, razão pela qual foram prontamente presos pela Polícia do Exército e passaram a figurar como investigados em inquérito instaurado para averiguar os crimes noticiados.

Procedendo com celeridade, a Justiça Militar instaurou o inquérito policialmilitar em 18 de janeiro de 1945, cuja solução data de 21 de janeiro de 1945. Uma vez finalizadas as investigações com a apuração da autoria e materialidade dos crimes, deu-se início ao processo instaurado perante a $2^{\mathrm{a}}$ Auditoria da $1^{\mathrm{a}} \mathrm{DIE}$, nos quais Adão e Luís 
tornaram-se réus, sendo processados e julgados pela Justiça Militar Brasileira, conforme se passa a expor.

\section{(ii) Do julgamento.}

Analisando os autos do processo no qual os acusados Adão Damasceno e Luís Bernardo restaram processados e sentenciados à pena capital (Apelação no 21-1945, no arquivo do Superior Tribunal Militar), é possível vislumbrar que a tutela jurisdicional prestada pela Justiça Militar Expedicionária Brasileira teve início com o recebimento do Ofício $\mathrm{n}^{\mathrm{o}} 15$ (Anexo n. 9), remetido em 18 de janeiro de 1945 pelo Major Chefe do Serviço de Polícia Militar ao Comandante da FEB, através do qual noticiava possível crime perpetrado por soldados da Força Expedicionária na localidade de Madognana:

\footnotetext{
"I- Leve ao conhecimento de V. Excia. Que esta repartição de Polícia recebeu dos Carabineiros locais uma documentação constante de seis (6) termos de declarações prestadas pelas vítimas de atentado levado a efeito por soldados brasileiros na localidade de MADOGNANA, na noite de nove de janeiro corrente, do qual resultou a morte do civil italiano VIVARELLI LEONARDO. II- Apesar da falta de dados positivos e do atraso com que tais declarações chegaram à Polícia, esta Chefia determinou que fossem procedidas investigações as quais, depois de alguns dias, viram-se coroadas de pleno existe. Pelos indícios e provas conseguidas surgiram como suspeitos e muito prováveis autores do atentado os soldados Adão Damasceno Paz e Luiz Bernardo de Moraes que trazidos à esta repartição para serem acariados com a vítima de violação carnal, MARGELLI GIOVANA, e com as testemunhas CANTELLI TONINA e SILVIO GALLI foram por estes reconhecidos como os verdadeiros autores dos crimes cometidos.

III- Presos e interrogados confessaram sem hesitação os crimes que praticaram tendo de suas declarações tomados os respectivos termos.

IV- Em face do exposto encaminho a V. Excia, os seguintes documentos que servirão de base ao processe que ora se inicia: 1- seis (6) termos de declarações prestadas por testemunhas e pela vítima de violação carnal (com as respectivas tradução em português); 2- Laudo Médico pericial com atestado da "Causa Mortis"; 3- Laudo médico pericial de exame procedido na pessoa da menor MARGELLI GIOVANA (Auto de Corpo de Delito); 4- Depoimento prestado e assinado pelo soldado Adão Damasceno Paz; Depoimento prestado e assinado pelo soldado Luiz Bernardo de Moraes".
}

Com efeito, é possível notar que a Polícia Militar, ao tomar ciência de suposto ilícito cometido por pracinhas brasileiros, adotou postura proativa a fim de averiguar os fatos; identificando os suspeitos, recolhendo-os ao cárcere, além de interrogar vítimas, testemunhas e autores, e encaminhando seus respectivos termos ao Comandante da FEB para que tomasse as devidas medidas. 
Verifica-se, ainda, que a Polícia Militar foi responsável por produzir substanciais elementos de provas, como o Laudo Causa Mortis de Leonardo Vivarelli (Anexo n. 10), que atribuía o evento mortis a -“ferimento por projétil de arma de fogo penetrante do tórax, com lesão dos vasos do pescoço. Anemia aguda"--; bem como o Auto de Corpo de Delito na vítima Giovana Margelli (Anexo n. 11), o qual não falhou em aclarar a materialidade delitiva e o defloramento da vítima.

A respeito do Auto de Corpo de Delito, convém aclarar que foram determinados quesitos a serem respondidos pela perícia, conforme se passa a expor:

\begin{abstract}
“(...) carregou-os de proceder ao exame em MARGELLI GIOVANA, filha de Frederico e de Vivarelli Lina, com 15 anos de idade, residente na Casa Bruciata, comuna de Granagliona, e que respondessem aos quesitos seguintes: $1^{\circ}-\mathrm{Se}$ a ofendia é virgem; $2^{\circ}$ - Se há sinais de congresso sexual recente; $3^{\circ}$ - Se há sinais de defloramento recente; $4^{\circ}$ - Se há outras lesões corporais que indiquem violência na consumação da ofensa; $5^{\circ}$ - Em caso afirmativo, quais as lesões e os meios empregados; $6^{\circ}$ - Se as lesões constatadas são de natureza a determinaram incômodo de saúde, especificando o prazo, inabilidade para o trabalho, mutilação, enfermidade incurável ou morte; $7^{\circ}$ - Se já alguma causa independente de idade, caracterizada por lesão ou perturbações funcionais de ordem física ou mental, que impossibilitassem a ofendida de resistir; $8^{\circ}$ - No caso afirmativo, quais as lesões ou perturbações. Em consequência passaram os peritos a fazer os exames e investigações ordenados e os que julgaram necessários, concluídas as quais, declararam o seguinte: que a ofendida relatou haver sido dominada fisicamente por um militar brasileiro, de cor escura, há seis dias passados, enquanto outro de cor branca, armado de arma de fogo montou guarda à entrada de sua casa; que foi pelo primeiro conduzida ao leito, sendo afastadas as suas vestes; que o mesmo a violentou sexualmente, sendo nesse momento tomada por terror e não tendo sentido qualquer sensação sexual ou dor; que nesse dia não teve hemorragia pelo canal vulvo-vaginal, iniciando-se no dia imediato pela manhã o fluxo menstrual; que não tivera nenhum congresso sexual anterior ao fato. Declararam mais os Peritos que encontraram ruptura do hímen da ofendida, com pregas longas, de ponta afilada, túrgidas e róseas e lesões vulvares constates de sufusões discretas na mucosa junto a implantação do hímen, não havendo no corpo da ofendida qualquer outra lesão traumática recente (...)".
\end{abstract}

A fim de facilitar a exposição dos quesitos, com a resposta aos mesmos, colaciona-se a seguinte tabela elucidativa:

Tabela 7: Quesitos do Laudo de Corpo de Delito de Giovana Margelli

\begin{tabular}{|l|c|}
\hline \multicolumn{1}{|c|}{ QUESITOS } & RESPOSTAS \\
\hline 1) Se a ofendida é virgem & NÃO \\
\hline 2) Se há sinais de congresso sexual recente & SIM \\
\hline 3) Se há sinais de defloramento recente & NÃO \\
\hline $\begin{array}{l}\text { 4) Se há outras lesões corporais que indiquem } \\
\text { violência na consumação da ofensa }\end{array}$ & PREJUDICADO \\
\hline 5) Em caso afirmativo, quais as lesões e os meios & \\
\hline
\end{tabular}




\begin{tabular}{|l|c|}
\hline empregados & \\
\hline 6) Se as lesões constatadas são de natureza a & PREJUDICADO \\
determinaram incômodo de saúde, especificando o & \\
prazo, inabilidade para o trabalho, mutilação, & \\
enfermidade incurável ou morte & NÃO \\
\hline 7) Se já alguma causa independente de idade, & \\
caracterizada por lesão ou perturbações funcionais & \\
de ordem física ou mental, que impossibilitassem a & \\
ofendida de resistir & \\
\hline 8) No caso afirmativo, quais as lesões ou & \\
perturbações & \\
\hline
\end{tabular}

Pois bem. Ao tomar ciência do ocorrido, o Comandante da FEB, Gen. de Divisão João Batista Mascarenhas de Moraes, delegou ao Capitão Sylvio de Mello Cahú, através da portaria de $\mathrm{n}^{\circ} 139$ (Anexo n. 12), a competência para instaurar inquérito policial militar ("IPM"), a fim de melhor averiguar os fatos no âmbito da Justiça Militar.

$\mathrm{O}$ inquérito policial militar se presta à apuração sumária do fato, a fim de verificar a configuração de crime militar e de sua autoria. Tem, portanto, o caráter de instrução provisória, cuja finalidade precípua reside em ministrar os elementos necessários à propositura da ação penal, ou seja, fornecer elementos para eventual instauração da ação penal.

Dessa forma, aos 18.01.1945, no acantonamento do Quartel General Avançado de Porreta-Terme, houve a autuação do IPM (Anexo. n. 13), no qual constava como encarregado o capitão Sylvio de Mello Cahú e como escrivão o $2^{\circ}$ Sargento Heitor Sulzer.

Instaurado no dia 18 do mês de janeiro, todo o procedimento de apuração dos fatos no bojo do IPM teve célere solução, tendo sido concluído no dia 21 de janeiro.

Ao longo dos três dias em que presidiu e conduziu o mencionado IPM, o Cap. Cahú se prestou a novamente à inquirir vítimas, autores e testemunhas, tendo sido comprovada a manutenção das mesmas versões dos fatos anteriormente descortinadas pela Autoridade Policial.

Como assinalado, os próprios acusados confessaram as ações delituosas, o que coincidiu com os depoimentos da vítima e das testemunhas. Apesar da confissão, ambos afirmaram, à época, terem agido em estado de embriaguez --a qual, conforme restaria comprovado, não foi capaz de influir na capacidade cognitiva de compreender o caráter 
criminoso dos atos, tanto que: (i) ao retornarem ao QG, entraram de serviço às $22 \mathrm{hrs} \mathrm{e}$; (ii) na manhã do dia seguinte, se deram ao cuidado de limparem as armas (fls. 34 e 60), a fim de evitarem quaisquer suspeitas--.

Concluído o IPM, o Cap. Sylvio de Mello Cahú elaborou relatório final (Anexo n. 14) determinando a prisão preventiva e imediata dos indiciados, forte nas seguintes razões, in verbis:

\begin{abstract}
"Examinando-se atentamente o presente inquérito policial-militar, verifica-se que no dia 9 corrente, cerca de 20:30 horas, na localidade de Madognana, na residência da menor Margelle Giovanna, os indiciados ADÃO DAMASCEDNO PAZ e LUIZ BERNARDO DE MORAIS, soldados do Pelotão de Defesa do Quartel General, da $1^{\text {a }}$ Divisão de Infantaria Expedicionária, aí chegaram e armados de metralhadoras portáteis, expulsaram de casa todos os seus moradores, dando rajadas com suas armas, sendo que o de nome ADÃO DAMASCENO PAZ levou a menor acima citada para um quarto e com ela teve relações sexuais, deflorando-a. Enquanto que o de nome LUIZ BERNARDO DE MORAIS, que ficava montando guarda na porta, assassinou o civil italiano VIVARELLI LEONARDO, que tentava socorrer a menor acima referida.

Há nos autos as provas materiais de folha 5 e 6 , as confissões dos indiciados de folhas $28,29,30$ e 31 , as declarações da ofendida a folhas 32 e 33 e a prova testemunhal de folhas $34,35,37,38,39,40,41,43$ e 44 , que evidenciam a responsabilidade que cabem a ditos indiciados.

Da prova colhida e no interesse da justiça é de ser decretado a prisão preventiva dos referidos indiciados.

Como o fato apurado constitui crime da competência dos tribunais militares, seja estes autos remetidos ao Exmo. Sr. General Comandante da $1^{\text {a }}$ Divisão de Infantaria Expedicionária".
\end{abstract}

Ato contínuo, procedeu com a remessa do feito de volta ao Comandante do Exército o qual, em 23.01.1945, encaminhou-o à $2^{\text {a }}$ Auditoria a fim de que o representante do Ministério Público verificasse a conveniência e a oportunidade do oferecimento de denúncia em desfavor dos Soldados Adão Damasceno e Luiz Bernardo de Morais.

Nesse sentido, em 25.01.1945 restou oferecida denúncia contra os soldados do Pelotão de Defesa do Q. G. avançado, na qual lhes foram imputados os tipos penais do art. $312^{272}$, parágrafo único, letra $\mathrm{b}$, combinado com o art. $192^{273}$, e do art. $302^{274}$, III, combinado com o artigo $181^{275}, \S 2^{\circ}, \mathrm{V}$, tudo do Código Penal Militar de 1944:

\footnotetext{
272 Art. 312. Praticar qualquer dos crimes de violência carnal previstos nos arts. 192 e 193, em lugar de efetivas operações militares:

Pena- reclusão, de quatro a doze anos.

Parágrafo único. Se da violência resulta:

a) lesão corporal de natureza grave:

Pena- reclusão, de oito a vinte anos;

b) morte:

Pena- morte, grau máximo; reclusão, de quinze anos, grau mínimo.

${ }^{273}$ Art. 192. Constranger mulher a conjunção carnal, mediante violência ou grave ameaça:

Pena- reclusão, de três a oito anos.
} 
“O representante do Ministério Público nesta Auditoria, no exercício das suas atribuições e com fundamento nos inclusos autos, vem apresentar denúncia contra:-ADÃO DAMASCENO PAZ, natural do Estado do Rio Grande do Sul, solteiro, soldado, servindo no Pelotão de Defesa do Q.G, filho de João Medina Damaceno Paz e Izaura Damaceno Paz, com 26 anos de idade e LUIZ BERNARDO DE MORAIS, natural do Estado do Rio Grande do Sul, solteiro, soldado, servindo no Pelotão de Defesa do. Q. G., filho de Lino Bernardino Dutra e Maria Candida de Morais com 21 anos de idade, como incursso nas sanções do art. $312 \S$ único, letra b c/c art. 192 e art. $302 \mathrm{n}^{\circ}$ III c/c art. 181, §2 do CPM, pelo que passa a expor: No dia 9 do corrente mês, cerca das 20 horas e 30 minutos, em Madognana, na residência da menor Margelle Giovanna, os denunciados que ai já tinham estado palestrando, chegaram armados com metralhadoras portáteis, entraram na sala onde estavam diversas pessoas, o segundo acusado deu uma rajada com sua metralhadora, apagando a luz do lampeão enquanto o primeiro agarrava a referida menor e os moradores, apavorados, fugiam da casa. Agarrada pelo primeiro acusado, foi Margelle Giovana dominada e levada para um quarto e aí foi por ele deflorada, (Auto de fls. 6) enquanto o segundo acusado permanecia na porta da casa vigiando-a para impedir a aproximação de alguém, sendo que nesse momento, tentando socorrer a ofendida foi o seu tio Vivarelli Leonardo, assassinado pelo referido segundo acusado com uma rajada de sua metralhadora, que lhe causou o ferimento descrito no Auto de fls. 5, que por sua natureza e sede foi a causa eficiente de sua morte. Depois de terminada a conjunção carnal pelo primeiro acusado, trocaram os papeis, ambos, indo o segundo para o quarto da ofendida e o primeiro ficou montando guarda na entrada da casa. O crime foi praticado com as agravantes das letras b, h, 1 e $\mathrm{n}$ do $\mathrm{n}^{\circ} \mathrm{II}$, do art. 59 do CPM.

Assim, para que sejam processados e, afinal julgados, espera esta Promotoria ver recebida e autuada a presente denúncia, para dar lugar a instrução criminal em dia e hora previamente designados, sendo citados os denunciados, sob pena de revelia, intimadas as testemunhas arroladas, pena de desobediência, e cumpridas as formalidades legais.".

A acusação, portanto, residiu no fato de os acusados, mediante ameaça, terem forçado a jovem italiana Giovanna Margelli, à violação sexual, e, visando assegurar a

\footnotetext{
${ }^{274}$ Art. 302. Praticar, em presença do inimigo, homicídio:

I- no caso do art. 181:

Pena- reclusão, de dez a trinta anos;

II- no caso do $\S 1^{\circ}$ do art. 181 :

Pena- reclusão, de seis a vinte anos;

III- no caso do $\S 2^{\circ}$ do art. 181 :

Pena- morte, grau máximo; reclusão, de vinte anos, grau mínimo.

275 Art. 181. Matar alguém:

Pena- reclusão, de 6 a 20 anos.

$\S 1^{\circ}$ Se o agente comete o crime impelido por motivo de relevante valor social ou moral, ou sob o domínio de violenta emoção, logo em seguida a injusta provocação da vítima, o juiz pode reduzir a pena de um sexto a um terço.

$\S 2^{\circ}$ Se o homicídio é cometido:

I- mediante paga ou promessa de recompensa, ou por outro motivo torpe;

II- por motivo fútil;

III- com emprego de veneno, fogo, explosivo, asfixia, tortura ou outro meio insidioso ou cruel, ou de que possa resultar perigo comum;

IV- à traição, de emboscada, ou mediante dissimulação ou outro recurso que dificulte ou torne impossível a defesa do ofendido;

V- para assegurar a execução, a ocultação, a impunidade ou vantagem de outro crime;

VI- prevalecendo-se o agente da situação de serviço:

Pena: reclusão, de doze a trinta anos.
} 
consecução desse delito, terem executado, a tiros de metralhadora, o tio daquela menor, Leonardo Vivarelli, quando este pretendia entrar na casa para salvá-la.

A denúncia foi recebida no dia posterior ao seu oferecimento, em 26.01.1945. Por conseguinte, os acusados restaram citados no dia 29.01.1945, sendo intimados (i) para apresentarem defesa e; (ii) comparecerem perante a $2^{\text {a }}$ Auditoria da $1^{\text {a }}$ D.I.E no dia 01.02.1945, a fim de serem interrogados perante aquele Juízo. Concomitantemente, foi também solicitada a remessa dos assentamentos funcionais dos acusados (Anexo n. 15), que atestava que ambos já haviam sofrido repressão disciplinar, não só por outras transgressões, como por abuso de álcool.

Em relação ao soldado Adão Damasceno Paz, pode-se visualizar ter ingressado na carreira militar no ano de 1942, no $1^{\circ}$ Regimento de Cavalaria Independente, tomando o n. 696, como reservista voluntário. De sua ficha funcional, destacam-se as seguintes anotações, ainda em exercício no Brasil:

Tabela 8: Destaques das Fichas Funcionais de Adão Damasceno e Luís Bernardo

\begin{tabular}{|c|c|}
\hline ELOGIOS & FALTAS \\
\hline \multicolumn{2}{|c|}{ NO $1^{\circ}$ REGIMENTO DE CAVALARIA } \\
\hline $\begin{array}{l}\text { Em março de } 1943 \text {, o Sr. Comandante do } 1^{\circ} \\
\text { Regimento de Cavalaria louvou-o pelo cuidado } \\
\text { demonstrado pelo seu cavalo e pela nítida } \\
\text { compreensão dos seus deveres. }\end{array}$ & $\begin{array}{l}\text { Em junho de 1943, ficou preso por } 8 \text { dias, por ter } \\
\text { abandonado o serviço de reforço e sair à rua sem } \\
\text { licença. Transgressão média. Permaneceu no bom } \\
\text { comportamento. }\end{array}$ \\
\hline & 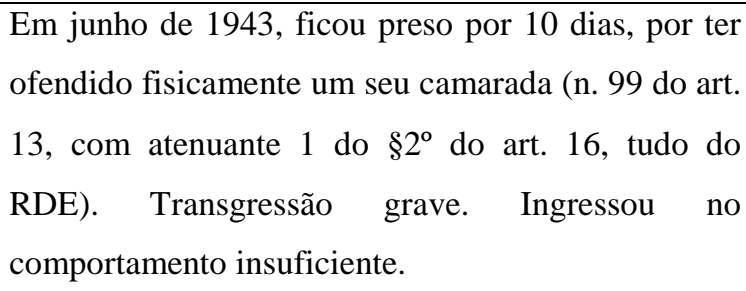 \\
\hline \multicolumn{2}{|c|}{ NA CIA DO QG DA $1^{\text {a }}$ D.I.E } \\
\hline & $\begin{array}{l}\text { Em agosto de 1944, ficou preso por } 8 \text { dias, por } \\
\text { haver se embriagado e respondido de maneira } \\
\text { desatenciosa ao Cmt. Da Guarda do Quartel, } \\
\text { fazendo-se necessária a presença do oficial de dia } \\
\text { (ns. } 99 \text { e } 117 \text { do art. } 13 \text {, com atenuante } 1 \text { do } \S 2^{\circ} \text { e } \\
\text { agravante } 2 \text { do } \$ 3^{\circ} \text { do art. } 16 \text {, tudo do RDE). Falta } \\
\text { Grave. }\end{array}$ \\
\hline
\end{tabular}


Da mesma forma, em relação ao soldado Luiz Bernardo de Moraes, verifica-se que ingressou nas forças armadas no ano de 1942, no $2^{\circ}$ Regimento de Cavalaria Independente, tendo tomado o n. 865 quando de sua incorporação. De sua ficha funcional, destaca-se as seguintes anotações, quando ainda em exercício no Brasil:

\begin{tabular}{|c|c|}
\hline ELOGIOS & FALTAS \\
\hline \multicolumn{2}{|c|}{ NO $1^{\circ}$ REGIMENTO DE CAVALARIA } \\
\hline & $\begin{array}{l}\text { Em fevereiro de } 1942 \text {, ficou preso por } 15 \text { dias, sem } \\
\text { fazer serviço, por ter faltado a parada geral e leitura } \\
\text { do boletim, ter saído para a rua estando detido e só } \\
\text { regressando no dia seguinte e ter faltado com a } \\
\text { verdade quando chamado pelo seu Cmt. De } \\
\text { Esquadrão (ns. } 25 \text { e } 26 \text { do art. } 13 \text {, com as agravantes } \\
\text { dos ns. } 2 \text { e } 6 \text { do } \S 3^{\circ} \text { e atenuante } 1 \text { do } \S 2^{\circ} \text { do art. } 16 \text {, } \\
\text { tudo do RDE). }\end{array}$ \\
\hline \multicolumn{2}{|c|}{ NA CIA DO QG DA $1^{\text {a }}$ D.I.E } \\
\hline & $\begin{array}{l}\text { Em dezembro de } 1943 \text {, ficou preso por } 20 \text { dias, por } \\
\text { ter sido preso por uma patrulha, na noite do dia } 22 \text {, } \\
\text { em completo estado de embriaguez (n. } 117 \text { do art. } \\
\text { 13, com as agravantes } 8 \text { e } 9 \text { do } \$ 3^{\circ} \text { do art. } 16 \text {, tudo } \\
\text { do RDE). Falta Grave. }\end{array}$ \\
\hline
\end{tabular}

Ainda, foi recebido pelo Juízo processante, por meio de Memorando $\mathrm{n}^{\mathrm{o}} 110$ encaminhado pelo Major Chefe do Serviço de Polícia Miliar, a informação de que -“o crime foi praticado em zona de efetivas operações militares"--, o que viria a ser o fator primordial levado em consideração para o apenamento máximo, a posteriori, dos acusados.

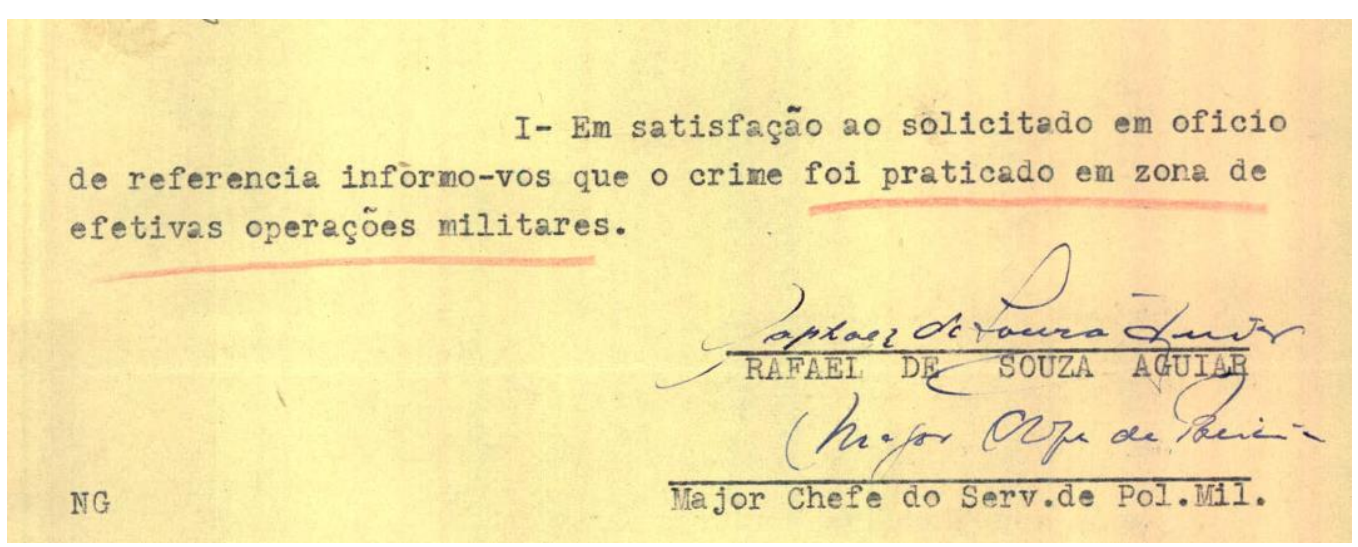


$\mathrm{Na}$ audiência de instrução e julgamento do processo, ocorrida em $1^{\circ}$ de fevereiro de 1945, mais uma vez foram ouvidas as testemunhas, a vítima e os denunciados, conforme consta da seguinte ata da sessão:

Ao primeiro dia do mês de fevereiro do ano de mil novecentos e quarenta e cinco, na séde do Serviço de Polícia Militar da la. D.I.E., em Porreta-Terme, Itália, para onde de deslocou esta Auditoria, ìs 8 horas da manhã, presentes os senhores, Tenente Coronel Eugênio Carvalho do Nascimento, Auditor, Capitão Orlando Moutinho Ribeiro da Costa, Promotor, 20 Tenente Bento Costa Lima Leite de Albuquerque, Advogado de Ofício, comigo, abaixo assinado, 2 우 Tenente Escrivão, foi aberta a sessão as 10 horas e 30 minutos.

Apregoados os nomes dos réus, soldados Adão Damaceno Pas e Luiz Bernardo de Morais, ambos do Pelotão de Defesa do Q.G.,, compareceram anbos acompanhados de escolta e do Advogado de ofício, tendo sido a seguir qualificados na fóma da lei.

Apregoados os nomes dastestemunhas arrolacas, compareceram todas, e foran inquiridas na fórma da lei.

A Promotoria não requereu diligências, nem a Defesa arrolou testemunhas, sendo a seguir os acusados interrogados na fórma da lei.

Nada mais havendo a tratar, foi suspensa a sessão, às 15 horas, regressando todos os componentes desta Auditoria sua séde, no Q.G. Recuado da la. D.I.E., em Pistoia, Itália, onde chegoy às 17 horas; do que, para constar, lavrei esta

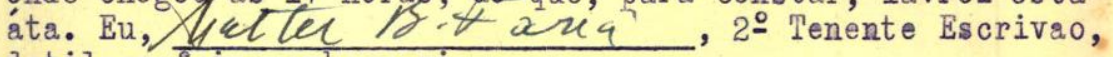
datilografiei e subscrevi.

Em que pese a reiteração dos termos já esposados pelos ouvidos, os denunciados, dessa vez, foram uníssonos em adotar uma postura mais cautelosa em relação à confissão em seus interrogatórios (Anexo. n. 16), respondendo aos questionamentos da seguinte forma: -“seu advogado dirá oportunamente"--.Finalizada a audiência, foi designado o dia 07.02.1945 para julgamento do feito:

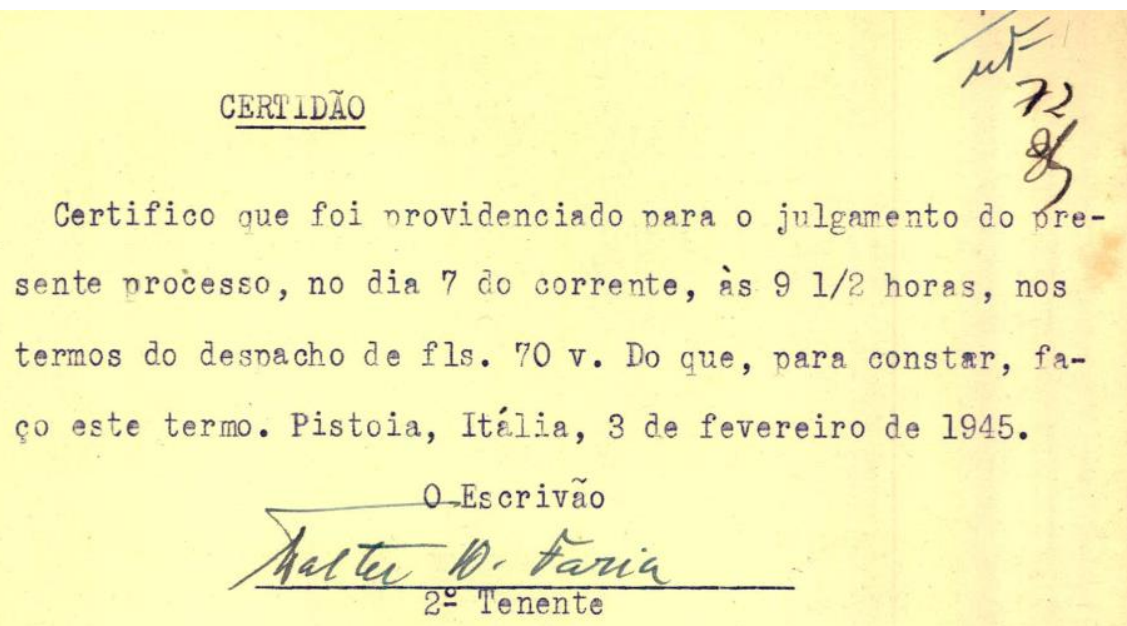


Dessa forma, depois de devidamente citados em 29 de janeiro, interrogados, juntamente com as testemunhas, em $1^{\circ}$ de fevereiro de 1945, os acusados restaram julgados e condenados no dia 07 de fevereiro de 1945.

Durante os debates orais no julgamento, o Capitão Orlando Moutinho Ribeiro da Costa, promotor que oficiava perante a $2^{\mathrm{a}}$ Auditoria da $1^{\mathrm{a}} \mathrm{DIE}$, sustentou que se achava provada a imputação feita na denúncia; que não eram bons os antecedentes dos acusados, e que havia contra eles as agravantes das letras $\mathrm{h}, 1 \mathrm{e} \mathrm{n}, \mathrm{n}^{\mathrm{o}} \mathrm{II}$, do art. $59^{276}$, pugnando pela condenação dos indiciados à pena máxima.

Contestando a acusação, o advogado Bento da Costa Lima Leite de Albuquerque argumentou que Adão Damasceno, não teria praticado o crime de violência que lhe fora imputado, uma vez que não houvera resistência por parte da vítima, tampouco fora responsável por atirar e matar alguém, pois se encontrava no quarto com Giovana.

Quanto a Luís Bernardo, argumentou que não agira dolosamente (com vontade de matar) e sim culposamente (ante às circunstâncias que se apresentavam: estava escuro, alguém vinha correndo em sua direção, então agiu com certa imprudência ao disparar a metralhadora) quando atirou contra Leonardo Vivarelli, pelo que pediu a absolvição daquele acusado.

Isto posto, seguiu-se o sentenciamento de ambos os réus na data de 07 de fevereiro de 1945, no acantonamento da cidade de Pistóia, Itália, onde funcionava a $2^{\mathrm{a}}$ Auditoria da $1^{\text {a }}$ D.I.E (Anexo n. 17).

Valendo-se dos exatos termos proferidos pelo Tenente Coronel e Juiz Auditor Eugênio de Carvalho do Nascimento, responsável por julgar o caso, assim restaram os soldados sentenciados:

\footnotetext{
"Considerando que, nos termos do art. 33 do CPM, quem concorre, de qualquer modo, para o crime, incide nas penas a este cominadas;

Considerando que, consoante a definição do art. 23, I, do mesmo Código, age dolosamente quem quer o resultado ou assume o risco de produzi-lo;

Considerando que, em face desses princípios, se torna irretorquível a co-autoria dos dois denunciados quer no delito de violência carnal, seja no de homicídio, pois, não só este foi cometido visando assegurar a execução daquele, como evidente é, pelo próprio desenrolar dos fatos, que os acusados haviam ajustado que se revezariam na prática do ato sexual, pactuando mais eles que um ficaria
}

\footnotetext{
${ }^{276}$ Art. 59. CPM 44: São circunstâncias que sempre agravam a pena quando não constituem ou qualificam o crime: (...) II- ter o agente cometido o crime:

h) contra criança, velho ou enfermo;

1) com emprego de arma ou instrumento de serviço para esse fim procurado;

n) em país estrangeiro.
} 
de guarda, à mão armada, para impedir, a qualquer custo, que alguém se aproximasse, enquanto o outro satisfizesse seu desejo sexual;

Considerando que tanto havia sido essa a deliberação de ambos, que, mesmo depois de avisado que seu companheiro já havia morto um homem, Adão Damasceno, não só continuou a violentar a menor, como, depois, se prontificou a ficar, como ficou, de guarda, também atirando com sua metralhadora, sempre que ouvia rumor, a fim de que Luís Bernardo, por sua vez, pudesse ter relação sexual com a mesma menor;

Considerando que, atendendo os antecedentes e a personalidade dos agentes, à intensidade do dolo, aos motivos, às circunstâncias e consequências dos crimes, ora sub-judice, os indigitados revelaram acentuada periculosidade, podendo-se nestas condições, estabelecer-lhes por pena base grau não inferior ao médio;

Considerando que, longe de haver qualquer circunstância que pudesse atenuar essa penalidade, há contra os indiciados as agravantes de terem cometido os delitos em estado de embriaguez, com emprego de armas de serviço procuradas para aquele fim, e em país estrangeiro, ex-vi do art. 59, II, letras c, b e n, do CPM;

Considerando que esses fatos, segundo informa o ofício a fls. 58, foram praticados em zona de efetivas operações militares, e, assim, nos termos do art. 318 do texto legal, devem ser tidos como cometidos em presença do inimigo, exigindo assim a repressão enérgica da Justiça, não só para a manutenção da Ordem e da Disciplina, como para resguardar forças aliadas e a população com que entramos em contato.

RESOLVO condenar, como condeno, os soldados Adão Damasceno Paz e Luís Bernardo de Morais à pena máxima do artigo 302, III, combinado com o artigo $181, \S 2^{\circ}, \mathrm{V}$, do CPM, a qual, sendo a de morte, pelo homicídio cometido para assegurar a execução da violência carnal, absorve a pena decorrente da prática deste delito, uma vez que dele não resultou o falecimento do agente passivo."

No dia seguinte ao que foi proferida a sentença condenatória, o advogado de ofício que atuava perante a $2^{\mathrm{a}}$ Auditoria da $1^{\mathrm{a}}$ D.I.E, Tenente Bento Costa Lima Leite de Albuquerque, apresentou, conforme lhe era determinado pelo art. 31 do Decreto- Lei $\mathrm{n}^{\circ}$ $6.396 / 44^{277}$, recurso de Apelação em favor de ambos os condenados:

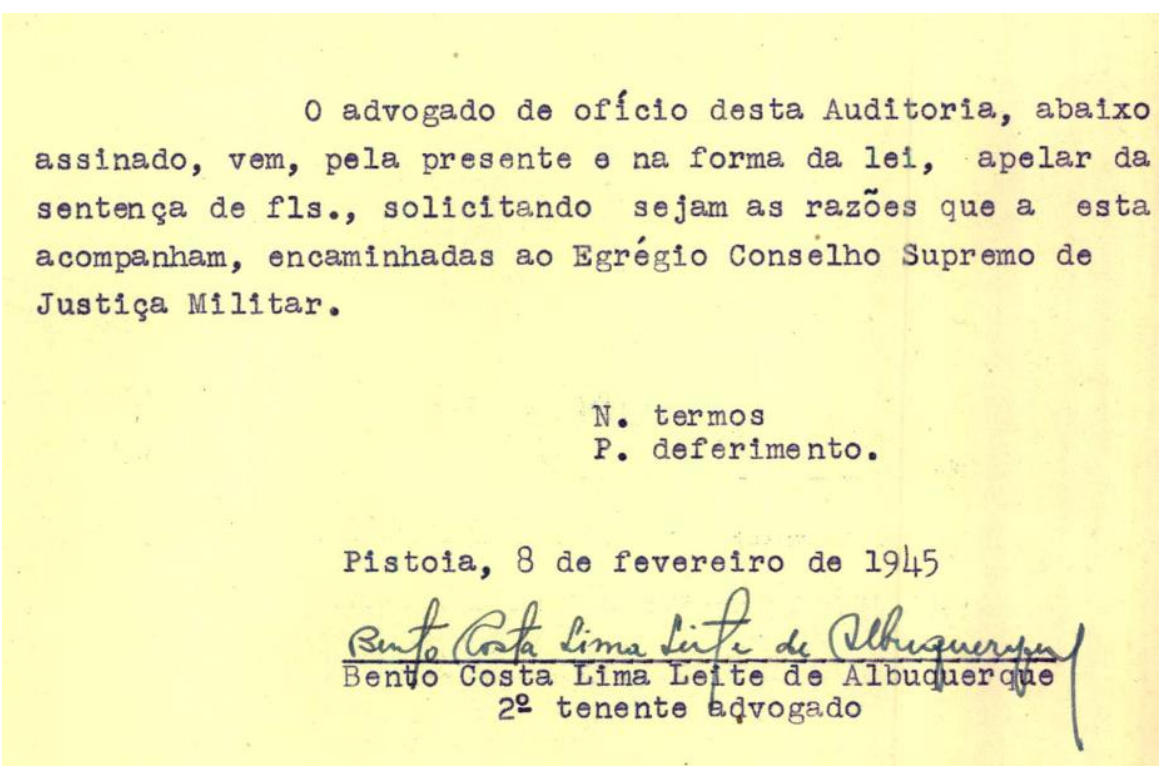

${ }^{277}$ Art. 31 do Decreto- Lei n ${ }^{\circ}$ 6.396/1944: O advogado de ofício apelará, obrigatoriamente, das sentenças condenatórias. 
Em sua apelação (Anexo n. 18), renovou os argumentos de que: (i) o primeiro denunciado, Adão Damasceno, não praticara o crime de violência, uma vez que não teria havido resistência por parte da vítima e; (ii) o segundo denunciado não agira dolosamente, e sim culposamente, quando atirou contra Leonardo Vivarelli; pelo que pediu a absolvição desses sentenciados:

"A respeitável sentença de fls. condenou os soldados ADÃO DAMASCENO PAZ e LUIZ BERNARDO DE MORAIS, à pena máxima do art. 302, III, combinado com o artigo 181, $\S 2^{\circ}$, V, do Código Penal Militar, "pelo homicídio cometido para assegurar a execução da violência carnal".

A participação dos soldados ADÃO E BERNARDO nos fatos de que resultou o presente processo é inteiramente diversa, sendo as ações de ambos perfeitamente independentes, mesmo quanto aos resultados oriundos.

ADÃO DAMASCENO PAZ, praticando a conjunção carnal com Marcelle Giovana, sem que o ato se tenha revestido das características da violência, não pode absolutamente ser responsabilizado pelos tiros que a embriaguez de seu companheiro disparou.

Os depoimentos dos soldados ADÃO e BERNARDO, reconhecidos pela douta sentença como confissão plena da culpabilidade de ambos, não podem ser invocados como prova de acordo preestabelecido, para a execução dos crimes de que são imputados. A regra do artigo 18 do Código Penal Militar -"O resultado de que depende a existência do crime somente é imputável a quem lhe deu causa" - deixa claro a não responsabilidade do soldado ADÃO na morte de Vivarelli Leonardo.

No momento dos disparos causadores da morte do referido italiano, o soldado ADÃO se encontrava no quarto dom Marcelle, não podendo, portanto, ser responsável pela imprudência de seu companheiro.

A declaração da "vítima" (fls. 23), não convence quanto à violência.

E, se ela no depoimento de fls. 64, diz ter sido subjugada, o tempo decorrido entre as duas declarações, pode ter influído numa falsidade, cousa lógica de se admitir pelo interesse que tem na punição do companheiro do causador da morte de seu tio.

XXX

A respeitável sentença aceitou a classificação do delito no artigo 302, III, apoiando-se para tanto, na informação da Chefia de Polícia da Divisão e, considerando como "presença do inimigo", a "zona de efetivas operações militares" onde se passaram os fatos, deixando, assim, de interpretar devidamente o artigo 318 do Código Penal Militar.

Para que se caracteriza a "presença do inimigo" é necessário que se tenha uma "zona de efetivas operações militares" que esteja na iminência ou em situação de hostilidades.

E tanto o é, que o Estatuto Penal Militar diferencia bem as situações, falando no Capítulo XI- Do homicídio e das lesões corporais, "em presença do inimigo"; no Capítulo XIIO Dos crimes contra o patrimônio, "em zona de operações militares" e, finalmente, no Capítulo XV- Do rapto e da violência carnal, "em lugar de efetivas hostilidades".

O lugar onde se passaram os fatos determinantes do caso "sub-judice", é zona de efetivas operações militares, como também é toda a zona de operações dos exércitos aliados na Itália.

Daí concluir que toda zona de operações militares, forçosamente tem que se encontrar "na iminência ou em situação de hostilidades", é fugir a verdadeira interpretação do texto legal.

EGRÉGIO CONSELHO:

$\mathrm{O}$ meritíssimo julgador não aplicou devidamente a lei, condenando à pena de MORTE os soldados ADÃO e BERNARDO. 
Responsabilidades diversas têm os mesmos e, ainda admitindo a co-autoria, a sentença apelada não poderia condena-los à pena do artigo 302, III, por não ter sido o crime praticado "em presença do inimigo".

À vista do exposto, pedem e esperam os apelantes, seja reformada a sentença, fazendo assim, esse EGRÉGIO CONSELHO, mais uma vez, a merecida JUSTIÇA."

Recebida a apelação, foi dada vista ao Promotor de Justiça para, querendo, apresentar contrarrazões de apelação (rebatendo as razões defendidas pelo advogado de ofício), o que foi feito no dia 09.02.1945, na qual expôs os fundamentos pelos quais os termos da sentença deveriam ser mantidos (Anexo n. 19):

\footnotetext{
"Evidentemente não tem razão os apelantes.

Os crimes praticados pelos acusados estão plenamente provados e a responsabilidade que lhes cabe, perfeitamente apurada.

A co-autoria está exuberantemente demonstrada, quer com as confissões prestadas pelos acusados, como pelas demais circunstâncias que se ligam ao caso. Estiveram pela tarde na casa da menor, voltaram ao Quartel General e, combinadamente, armados com metralhadoras, voltaram a referida casa para a prática do crime de conjunção carnal. Enquanto o primeiro acusado violentava e deflorava a menor o segundo montava guarda à porte, momento em que matou com uma rajada o velho tio da mesma. Depois trocaram papeis, indo o primeiro para a porta e o segundo para o quarto.

Como, neste caso tão evidente, contestar a co-autoria?

Os crimes praticados revestiram-se de suma barbaridade, já pela criança deflorada estupidamente sob uma ameaça terrível estando os acusados armados com metralhadoras e dando rajadas com as mesmas, já pela morte do velho que procurava naturalmente, evitar aquele crime, mas, ante a ameaça retirava-se sem resistência.

Fatos idênticos vem se repetindo, uns atrás dos outros, chegando ao conhecimento da Justiça e dando mostras que os comandos não tem meios para por paradeiro a eles. Nem mesmo a ação discreta dos Capelães Militares consegue refrear instintos mais nesses momentos, deixando claro que toda energia é pouca.

A sentença recorrida bem apreciou a prova dos autos e meditadamente aplicou a lei.

Assim, sendo negado provimento a apelação interposta pelos acusados, soldados Adão Damasceno Paz e Luiz Bernardo de Morais, como improcedente, mais uma vez fará esse Egrégio Conselho a merecida JUSTIÇA.”
}

Contudo, mais do que oferecer uma visão contrária ao recurso apresentado, a promotoria da Justiça Militar aproveitou para alardear, ao Conselho Supremo de Justiça Militar, que iria julgar a apelação na sede em funcionamento no Rio de Janeiro, para o fato de que -“(...) Fatos idênticos vem se repetindo, uns atrás dos outros, chegando ao conhecimento da Justiça e dando mostras que os comandos não tem meios para por paradeiro a eles. Nem mesmo a ação discreta dos Capelães Militares consegue refrear"--.

A partir dessa preocupação exposta pelo órgão de acusação da Justiça Militar, resta claro que fatos semelhantes estavam se repetindo e que o comando militar não estava 
conseguindo conter a reiteração dessas práticas delituosas. Por tal razão, se impunha uma sentença e uma condenação exemplar, que saltassem aos olhos dos expedicionários, na tentativa restaurar a manutenção da ordem da tropa.

Com efeito, a apelação, tombada como Apelação nº 21- Pistóia- Itália, foi distribuída à relatoria do Presidente do CSJM, General de Divisão Boanerges Lopes de Souza, a quem coube apresentar os fatos e proferir voto perante os demais membros CSJM, que já funcionava na cidade do Rio de Janeiro, nas dependências da Escola de Educação Física do Exército, na Fortaleza de São João, na Urca, consoante o art. $1^{\circ}$ do Decreto-Lei no 7.057 , de 20/XI/1944 ${ }^{278}$.

Nesse ponto, não é demais relembrar que competia ao Conselho Supremo da Justiça Militar o julgamento de recursos de apelação das sentenças de primeira instância, consoante o preconizado no Decreto-Lei n ${ }^{\circ} 6.396$ de 01.04.1944 ${ }^{279}$.

Assim sendo, no dia 07 de março de 1945, reunidos na então Capital Federal do Brasil, os Juízes do Conselho Supremo de Justiça Militar julgaram o recurso de Apelação $\mathrm{n}^{\mathrm{o}} 21$ interposto em face da sentença condenatória dos réus Adão Damasceno e Luís Bernardo, em sessão de julgamento que assim transcorreu:

Primeiramente, consoante o preconizado pelo art. 36 do Decreto-Lei $\mathrm{n}^{\circ}$ 6.396/44, o Gen. Boanerges Lopes de Souza expôs sua visão dos fatos apresentados nos

\footnotetext{
278 Decreto-Lei $\mathrm{n}^{\circ}$ 7.057, de 20 de novembro de 1944. "O PRESIDENTE DA REPÚBLICA: Considerando que as condições especiais que revestem atualmente as operações em que estão sendo empenhadas as Forças Expedicionárias Brasileiras, não exigem o acompanhamento das tropas pelos tribunais de segunda instância e usando das atribuições que confere o artigo 180 da Constituição, decreta:

Art. $1^{\circ}$ - O Conselho Supremo de Justiça Militar, de que trata o Dec.- Lei $n^{\circ}$ 6.396, de 1 de abril de 1944, passa a ter sede na Capital da República, ou onde fôr designado pelo Govêrno."

${ }^{279}$ Decreto-Lei ${ }^{\circ} 6.396$, de $01^{\circ}$ de abril de 1944.

Art.28- Das sentenças de primeira instância caberá recurso de apelação para o Conselho de Justiça Militar.

Parágrafo único.- Não caberá recurso das decisões proferidas sobre preliminar ou questões incidentes. Essas preliminares ou questões poderão, entretanto, ser renovadas na apelação.

Art. 29- A apelação será interposta, dentro de vinte e quatro horas, a contar da intimação da sentença ao Promotor ou ao defensor do réu, revel ou não.

(...)

Art. 31- O advogado de ofício apelará, obrigatoriamente, das sentenças condenatórias.

Art. 32- As razões de recurso serão apresentadas, com petição, em cartório. Conclusos os autos ao Auditor, este os remeterá, incontinenti, ao Conselho Supremo de Justiça Militar.

Art. 33- A apelação será distribuída, por ordem de entrada dos processos, aos juízes, inclusive ao presidente, que fará a distribuição.

Art. 34- O Procurador- Geral oficiará nos recursos interpostos pelos promotores e naqueles em que, depois de examinados os autos pelo relator, verificar este a necessidade de sua audiência, devendo emitir parecer dentro de vinte e quatro horas.

Art. 35- O relator estudará os autos no intervalo de duas sessões.

Art. 36- Anunciado o julgamento, fará o relator, oralmente, a exposição do fato.

$\S 1^{\circ}$ - Terminado o relatório, poderão o advogado do réu e o Procurador Geral fazer alegações orais, por dez minutos, cada um.

$\S 2^{\circ}$ - Discutida a matéria pelo Conselho Supremo de Justiça Militar, proferirá este sua decisão, que se realizará em sessão secreta, se o réu estiver solto, ou quando assim for deliberado."
} 
autos que lhe foram distribuídos, de forma mais completa e detalhada em comparação aos fatos retratados na sentença condenatória de $1^{\mathrm{a}}$ instância.

Assim, consignou que Giovanna já seria conhecida de Adão Damasceno (não especificando de onde) e estava há poucos dias na cidade prestando assistência à sua avó, conquanto residia em uma localidade próxima, "Casa Bruciata". Em relação ao iter criminis, se ateve aos detalhes dos depoimentos e relatórios do processo, aclarando aos seus pares que:

"Seriam 20 horas quando bateram à porta da casa. "Estavam bem uniformizados", com o rosto coberto pelo "passa-montanha"(agasalho de lã para o rosto e cabeca), disseram as testemunhas.

Depois de trocarem algumas palavras, Luís Bernardo levantou-se e apoiou a metralhadora sobre o espaldar da cadeira que the tinha sido oferecida, ao mesmo tempo em que Adão Damasceno se aproximou de Giovanna, dizendo-lhe: "se falas, eu te mato" (depoimento da vítima, a fls 24), pondo em execucão o plano que havia projetado.

Luís Bernardo apagou a luz, dando uma rajada de metralhadora sobre o lampião de querosene; acendeu sua lanterna elétrica e passou a ameaçar as pessoas presentes com a metralhadora, com a qual fez vários disparos. Atirou em Giuseppe, que logrou escapar-se; Stefano fugiu pela porta, abrigando-se em uma casa vizinha, morada de seu tio Ítalo, onde encontrou Tonina, que havia fugido pela janela. Houve um verdadeiro pânico.

O soldado Adão Damasceno aproveitou a confusão e se atirou sobre a vítima Giovanna - Subjugou-a e levou-a à força para o quarto, onde a deflorou.

É o próprio soldado Adão que confessa em seu depoimento: "Terminado o jantar, apanhamos nossas metralhadoras e subimos novamente para Madognana, dirigindo-nos para a casa. Lá chegados, vimos que o pessoal da casa estava se esquentando, e nós resolvemos também nos esquentar. Meu companheiro sentou-se e eu lhe disse: "vamos apagar a luz de uma vez, a fim de poder pegar a mulher no escuro. A mulher que nós queríamos pegar era a tal que eu tinha dito que era mal-educada. $O$ meu companheiro deu uma rajada de metralhadora na luz e eu segurei a mulher. $O$ meu companheiro ficou de guarda e eu carreguei a mulher para a cama, tendo o resto do pessoal fugido. Eu forcei a mulher, tendo satisfeito o meu desejo sexual com ela, e o Luís Bernardo ficou dando rajadas no pessoal e também num homem que queria entrar. O Luís gritou que me apurasse, pois ele tinha morto um homem. Depois saí para ficar de guarda, enquanto o meu companheiro se agarrava com a mesma mulher (Margelli Giovanna), de 15 anos de idade! Sentindo barulho do lado de fora, e pensando que viesse gente, dei uma rajada de metralhadora para fora, pela porta de entrada que se encontrava meio aberta. Depois que o meu companheiro se serviu da mulher, nós saímos pela mesma porta de entrada e vimos que havia um homem morto na rua, do lado direito de quem sai da casa". Luís Bernardo, em seu depoimento, confirmou essas declarações.

(...) Entretanto, Luís Bernardo, embora tenha passado cerca de meia hora no quarto com Giovanna, não conseguiu realizar a conjunção carnal, por se sentir impotente, fato que atribuiu ao estado de embriagues em que se achava. (...) Praticado o revoltante crime, fugiram os dois soldados. Na fuga, Luís Bernardo deixou cair a lanterna elétrica e o cachenez, os objetos que foram encontrados no dia seguinte por Ítalo Vivarelli, irmão de Leonardo, o morto, e por ele entregues às autoridades na ocasião em que foi queixar-se, acompanhado de seu sobrinho Stefano Canteli." 
Fez questão, ainda, o aludido General, de ressaltar a controversa alegação de Adão Damasceno:

\begin{abstract}
"Adão Damasceno diz ter agido em estado de embriaguez, mas ele, como o seu companheiro Luís Bernardo, embora embriagados, como alegaram, tiveram o cuidado, na manhã seguinte, de limpar as armas de que tinham servido a noite do crime, o que vem atestar que tinham conhecimento dos atos criminosos que praticaram."
\end{abstract}

Quanto ao aspecto formal, teceu análise de que todo trâmite processual havia sido respeitado: polícia militar realizou investigação preliminar dos fatos; uma vez transmitida a notícia do crime ao Comandante do Exército, foi determinada a instauração de inquérito a fim apurar a autoria e materialidade do delito; comprovação se deu a partir dos laudos periciais produzidos, além das oitivas de testemunhas e confissões dos acusados. No mesmo sentido transcorreu a ação penal, com oferecimento de denúncia; nova oitiva de vítimas, testemunhas e réus; oferecimento de defesa; debates orais; sentença condenatória; apelação; parecer do ministério público e; o derradeiro julgamento do CSJM. A seguir, continuou:

\begin{abstract}
“Afinal, proferiu o Dr. Auditor a douta sentença de fls. 73 a 79, pela qual condenou os soldados Adão Damasceno Paz e Luís Bernardo de Moraes à pena máxima do art. 302, III, combinado com o art. $181, \S 2^{\circ}$, V, do CPM, a qual sendo de morte pelo homicídio cometido para assegurar a violência carnal, absorve a pena decorrente da pratica do agente passivo.

E o Dr. Promotor, no parecer de fls. 86v. e 87, ao solicitar do Conselho Supremo fosse negado provimento à apelacão interposta pelos acusados, como improcedente, reafirma «que os crimes praticados pelos denunciados estão plenamente provados e a responsabilidade que lhes cabe, perfeitamente apurada. A co-autoria esta exuberantemente demonstrada, quer pelas confissões feitas pelos acusados, quer pelas circunstâncias que se ligam ao caso. (...) E acrescenta o representante do Ministério Público: «Fatos idênticos vem se repetindo, uns atrás dos outros, chegando ao conhecimento da Justica e dando mostra que os comandos não têm, meios para por paradeiros a eles. Nem mesmo a acão discreta dos capelães militares consegue refrear instintos maus nesses momentos, deixando claro que toda energia é pouca».

Dada vista ao Exmo. Sr. General Procurador, apresentou Sua Excelência fundamentado parecer (fis. 94), conc1uindo por opinar pela confirmacão da sentenca apelada."
\end{abstract}

Nesse ponto, convém trazer à baila o mencionado parecer apresentado pelo General de Brigada R2 e Procurador Geral, Waldomiro Gomes Ferreira, que também oficiava naquela Capital Federal.

Tombado como Parecer de $n^{\circ}$ 8, de 05.03.1945 (Anexo. n. 20), expõe diversas impressões de índole pessoal e de revolta por parte do então Procurador Geral. Nada 
obstante, restou apropriado pelo Julgador de Segunda Instância que, sem a menor cerimônia, reproduziu o entendimento em suas razões de decidir perante o CSJM.

Assim sendo, não é demais apresentar, a seguir e in verbis, o parecer do Procurador Geral, que assim se manifestou pela confirmação da sentença condenatória de primeiro grau:

"Os soldados Adão Damasceno Paz e Luís Bernardo de Moraes confessaram friamente, com abundância de detalhes, os crimes que praticaram em Madognana, comuna de Granaglione, Itália.

Relatam eles que (...) para facilitar a execução de delito, por demais revoltante, Luís Bernardo colocou-se de guarda, à porta, atirando em Vivarelli Leonardo, quando este regressava de uma visita. E, logo depois, gritou «apressa-te (Adão) que já matei um homem».

Consumado o ato sexual, que o incidente ora descrito, a rápidos traços, nem sequer interrompeu, Adão Damasceno ficou, também de guarda, para que Luís se servisse, igualmente, da desventurada Margelli. Não pôde, entretanto, realizar a cópula, por impotência ocasional, oriunda do estado de embriagues em que se encontrava.

$\underline{O}$ inquérito foi instaurado em consequência de «declaracões prestadas pelas vítimas do atentado», e entregues pelos carabineiros locais à Chefia do Servico de Polícia Militar, fIs. 9.

Foram ouvidas, na instrucão criminal, três testemunhas numerárias. Uma, Galli Sylvio, declarou - «que devido à escuridão existente, quer na estrada, seja na casa da família Cantelli, não guardou a fisionomia do soldado que, com o depoente, teve as ocorrências narradas em seu depoimento, fls. 67v. As restantes assistiram à confissão dos acusados, no inquérito, fIs. 68 e 68v. Depuseram ainda, além da ofendida, duas testemunhas informantes: Cantelli Tonina reconheceu, nos dois acusados, as pessoas que estiveram, em sua casa, às $16 \mathrm{e} 20$ horas, praticando os atos constantes das declaracões anteriores, fIs. 66, e Cantelli Steffano, que se exprimiu assim, a fls. 67: «que embora tenha aberto a porta para os soldados brasileiros que entraram em sua casa, não pode afirmar que os referidos soldados sejam os denunciados presentes, visto como a casa do declarante se achava mal iluminada».

Os acusados revelaram, no cometimento de tão graves infrações, ocorridas em zona de efetivas operações militares, fIs. 58, absoluta falta de senso moral. Sua notícia causa dolorosa impressão em todos os espíritos.

A infortunada Margelli se viu despojada de sua honra sexual, em plena mocidade, e um homem tombou sem vida, por gesto meramente sanguinário.

Estatui o Código da Justiça Militar, que o art. 57 do Decreto-Lei no 6.396, de $1^{\circ}$ de abril de 1944, manda observar no que não colidir com esse diploma:

Art. 182. - Nos casos em que possa ser aplicada pena de morte ou de trinta anos de prisão, a confissão, nos termos do artigo anterior (se livre e acorde com as circunstâncias do fato) sujeita o réu à pena imediatamente menor, se não houver outra prova do crime.

O Código Penal Militar prescreve:

Art. 62. - São circunstâncias que sempre atenuam a pena:

IV - Ter o agente:

d) confessado espontaneamente, perante autoridade, a autoria do crime, ignorada ou imputada a outrem. 
Acrescenta o $\S 1^{\circ}$ do mesmo dispositivo, «nos crimes em que a pena máxima é de morte ou de reclusão por vinte anos, ao juiz é facultativo atender ou não às circunstâncias atenuantes enumeradas no artigo».

Não mais vigora, em face do exposto em último lugar, o preceito do art. 182 do Código de Justiça Militar, que não autorizava a aplicabilidade da pena de morte, com apoio exclusivo na confissão do delinquente.

Atualmente, é permitido decretá-la em tal hipótese, sem amparo em prova de outra natureza, que, aliás, existe no processo, embora de testemunha informante, mas cujo depoimento se ajusta às circunstâncias do fato.

É a conclusão que emerge do $\S 1^{\circ}$ do art. 62, que, faculta ao Juiz desprezar a atenuante da confissão da autoria do crime, ignorada ou imputada a outrem, quando se tratar de delito punido, no máximo, com a pena de morte ou de reclusão por 20 anos, naturalmente para que possa aplicar esta ou aquela, mesmo se os autos não fornecerem outros elementos de criminalidade.

Nem a atenuante do art. 62, no IV, alínea d, milita em favor dos acusados, segundo mostram os tópicos, adiante transcritos, do ofício do Sr. Major Chefe do Servico de Policia Militar, a fIs. 9:

Pelos indícios e provas conseguidas surgiram como suspeitos e muito prováveis autores do atentado os soldados Adão Damasceno Paz e Luís Bernardo de Moraes, que, trazidos a esta repartição para serem acareados com a vítima da violação carnal, Margelli Giovanna, e com as testemunhas Cantelli Tonina e Sílvio Galli, foram por estes reconhecidos como os verdadeiros autores dos crimes cometidos.

Presos e interrogados, confessaram sem hesitação os crimes que praticaram, tendo de suas declarações sido tomados os respectivos termos.

Quem, de qualquer modo, concorre para o crime, incide nas penas a este cominadas (art. 33 do Código Penal Militar).

O soldado Adão é, também responsável pela morte de Vivarrelli Leonardo. Ele e Luís Bernardo pactuaram a ida à casa de Margelli. Saíram do Quartel, armados de metralhadoras portáteis.

Foi Luís quem apagou a luz, a pedido de Adão Damasceno, e «permaneceu de guarda na porta», a fim de auxiliar o co-partícipe.

Luís Bernardo matou precisamente no momento em que Adão violentava a infeliz jovem. Houve, assim, a concorrência criminosa de que cogita o mencionado art. 33, e que pressupõe, como se verificou na espécie, e adverte COSTA E SILVA, em Código Penal vol. 1, pág. 199, certo liame psicológico entre os indivíduos que nela tomarem parte.

Opino pela confirmação da sentença apelada."

Isto posto, seguem as razões de decidir do Gen. Boanerges Lopes de Souza, as quais embasaram a opinio delicti dos demais membros do CSJM, que houve por bem assim julgar em derradeira instância os fatos apresentados:

“Considerando que os crimes imputados aos soldados Adão Damasceno Paz e Luís Bernardo de Moraes ficaram evidenciados, de acordo com as provas nos autos;

Considerando que, nos termos do art. 33do C.P.M, quem concorre, de qualquer modo, para o crime, incide nas penas a este cominadas;

Considerando que, consoante a definição ao art. 23, I, do mesmo Código, age dolosamente quem quer o resultado ou assume o risco de produzi-lo;

Considerando que a co-autoria está, assim, perfeitamente caracterizada, quer no delito de violência carnal, quer no de homicídio;

Considerando que, atendendo aos antecedentes e à personalidade dos agentes, à intensidade do dolo, aos motivos, às circunstâncias e consequências dos crimes, os acusados revelaram acentuada periculosidade, o que levou o Dr. Auditor a estabelecer, como pena base, grau não inferior ao médio; 
Considerando que, na ausência de atenuantes, há contra os indiciados as, agravantes previstas no art. 59, II, letras e, 1 e n do C.P.M.;

Considerando que esses crimes, consoante declaração do Chefe de Polícia da FEB, a fIs. 59, foram praticados em zonas de efetivas operações militares, e, exvi do art. 318 do mesmo Código, devem ser considerados como cometidos em presença do inimigo, exigindo, assim corno muito bem se expressou o Dr. Auditor que proferiu a sentenca, repressão enérgica da Justica com o fim de assegurar não só a manutencão da ordem e da disciplina, como o respeito e a confianca que as Forcas Expedicionárias Brasileiras devem inspirar aos nossos aliados no teatro de operacões e junto à populacão em contato com as mesmas Forcas;

Considerando que o Código de Justiça Militar prescreve que o art. 47 do Decreto-Lei $n^{\circ} 6.396$, de $1^{\circ}$ de abril de 1944 , manda observar no que não colidir com o mesmo Código em seu art. 182: «Nos casos em que possa, ser aplicada a pena de morte ou de 30 anos de prisão, a confissão, nos termos do artigo anterior (as livres e acordes com as circunstâncias do fato) sujeita o réu à pena imediatamente inferior, se não houver outra prova do crime» (parecer do Exmo. Sr. Procurador Geral);

Considerando, porém, como muito bem esclareceu o Procurador Geral, que não prevalecem no caso sub-judíce as circunstâncias previstas no art. 62 do C.P.M., que sempre atenuam a pena:

IV-Ter o agente:

d) Confessado espontaneamente, perante a autoridade a autoria do crime, ignorada ou imputada a outrem.

No caso em apreco, a confissão não foi espontânea e resultou de providências tomadas pelo Major Chefe do Servico de Polícia Militar da FEB. (documento a fls. 9), aqui transcritas:

«Pelos indícios e provas conseguidas, surgiram como suspeitos e muito prováveis autores do atentado os soldados A.D.P. e L.B. de M., que trazidos a esta repartição para serem acareados com a vítima da violação carnal, Margelli Giovanna, e com as testemunhas Cantelli Tonina e Silvio Galli, foram por estas reconhecidos como os verdadeiros autores dos crimes cometidos. Presos e interrogados, confessaram, sem hesitação, os crimes que praticaram, tendo de suas declarações sido tomados os respectivos termos»;

Considerando, afinal, que, mesmo na hipótese de terem sido espontâneas as confissões, ao Juiz é facultativo atender ou não as circunstâncias atenuantes enumeradas no artigo acima citado, «nos crimes em que a pena máxima é a de morte ou de reclusão por vinte anos», de acordo com o que prescreve o $\S 1^{\circ}$ do mesmo dispositivo legal, não estando, portanto, em vigor o preceito do art. 182, que não autorizava a aplicabilidade da pena de morte com apoio exclusivo na confissão do delinquente, como ainda pondera o Exmo. Sr. Procurador Geral;

Acordam os Juízes do Conselho Supremo de Justiça Militar em negar provimento à apelação, para confirmar, como confirmam, a sentença que condenou os soldados Adão Damasceno Paz e Luís Bernardo de Moraes à pena máxima ao art. 302, III, combinado com o art. 181, § $2^{\circ}$, V, do Código Penal Militar."

Assim sendo, o CSJM houve por bem, na data de 07 de março de 1945, ratificar, à unanimidade, a pena capital sancionada em primeira instância aos soldados Adão Damasceno Paz e Luiz Bernardo de Morais.

Nada obstante, em que pese os demais membros da CSJM terem acompanhado e votado pela procedência dos termos ditados pelo Relator no acórdão 
condenatório, estes fizeram questão de expor breves manifestações acerca dos fatos julgados, conforme se passa a expor.

Primeiramente, o General de Divisão R2 e Ministro Washington Vaz de Mello, juiz togado, justificando o seu ponto de vista na confirmação da pena, houve por bem assim se manifestar:

"Votei pela confirmação da sentença apelada, nos termos do bem fundamentado acórdão de fls. 97 a 106, por entender que de outro modo não poderiam ser punidos os bárbaros autores de tamanha selvageria.

Confessaram eles, com revoltante cinismo, os abomináveis crimes que praticaram, revelando absoluta falta de senso moral como ressalta em seu douto parecer o ilustrado representante do Ministério Público junto a este Conselho Supremo.

Já haviam estado na casa em que se encontrava a menor Margelli e combinaram ali voltar para violenta-la, saindo do Quartel, depois do jantar, armados com metralhadoras portáteis.

Ao penetrarem no interior da referida casa, um deles - o soldado Luís Bernardo de Moraes - deu, a pedido de Adão Damasceno Paz, «uma rajada de metralhadora», apagando a luz. Tomados de pânico, fugiram os seus moradores deixando a infortunada menor entregue à sanha dos assaltantes. Levada esta, à força, para o quarto pelo soldado Adão que a violentou, ficou seu companheiro de guarda, na porta de entrada, vindo momentos depois assassinar, fria e covardemente, ainda com uma descarga de metralhadora, o tio de Margelli, Vivarelli Leonardo, que, despreocupadamente, regressava de uma visita, ignorando por completo o que ali estava ocorrendo.

Demonstrando completa solidariedade com o seu companheiro, que lhe dissera haver morto um homem, tomou o soldado Adão, sua metralhadora e foi, por sua vez, montar guarda à porta, para que Luís Bernardo saciasse também, na infeliz menor, seus desejos bestiais.

O Código Penal Militar coloca no mesmo pé de igualdade todas as condições do evento, considerando co-autor quem, de qualquer modo, concorre para o crime (art. 33).

Embora os disparos que ocasionaram o homicídio, houvessem sido feitos por Luís Bernardo, não se pode excluir a responsabilidade do soldado Adão Damasceno por esse crime. --Entre os acusados existia um laço psicológico, que tornou comum a ambos a mesma ação delituosa--.

No caso não se verificou nenhuma atenuante que pudesse minorar a situação dos réus.

Tratando-se de crimes praticados em zonas de efetivas operações militares (fls. 59 , e atendendo às circunstâncias de que se revestiram impunha-se a aplicação da pena capital."

Outrossim, o General de Brigada Francisco de Paula Cidade assim se posicionou:

"Deixo de pedir vista destes autos, não obstante a importância do processo, porque estudei demoradamente, com os outros juízes, e me acho perfeitamente informado. Aliás, não há a menor dúvida quanto ao crime e sua autoria.

Votando, como voto, pela confirmacão da sentenca, defendo a honrado Exército e a própria civilizacão brasileira. Não fossem os embaracos opostos pela moderna legislação, estou certo de que o comandante das 
forças brasileiras na Itália teria, com grande proveito para a boa ordem de suas tropas, feito fuzilar, sem quaisquer delongas, esses criminosos."

A partir da leitura dos votos proferidos, resta manifesta a repulsa dos julgadores em relação aos crimes praticados por Adão e Luís Bernardo. Deixam transparecer, sem o menor pundonor, e por diversas vezes, que opiniões de índole pessoal influíram em suas convicções judicantes, conforme se verifica na tabela abaixo, produzida com trechos destacados de seus votos (parecer no caso do Procurador-Geral):

Tabela 9: Trechos de destaque do julgamento da Apelação n²1 pelo CSJM

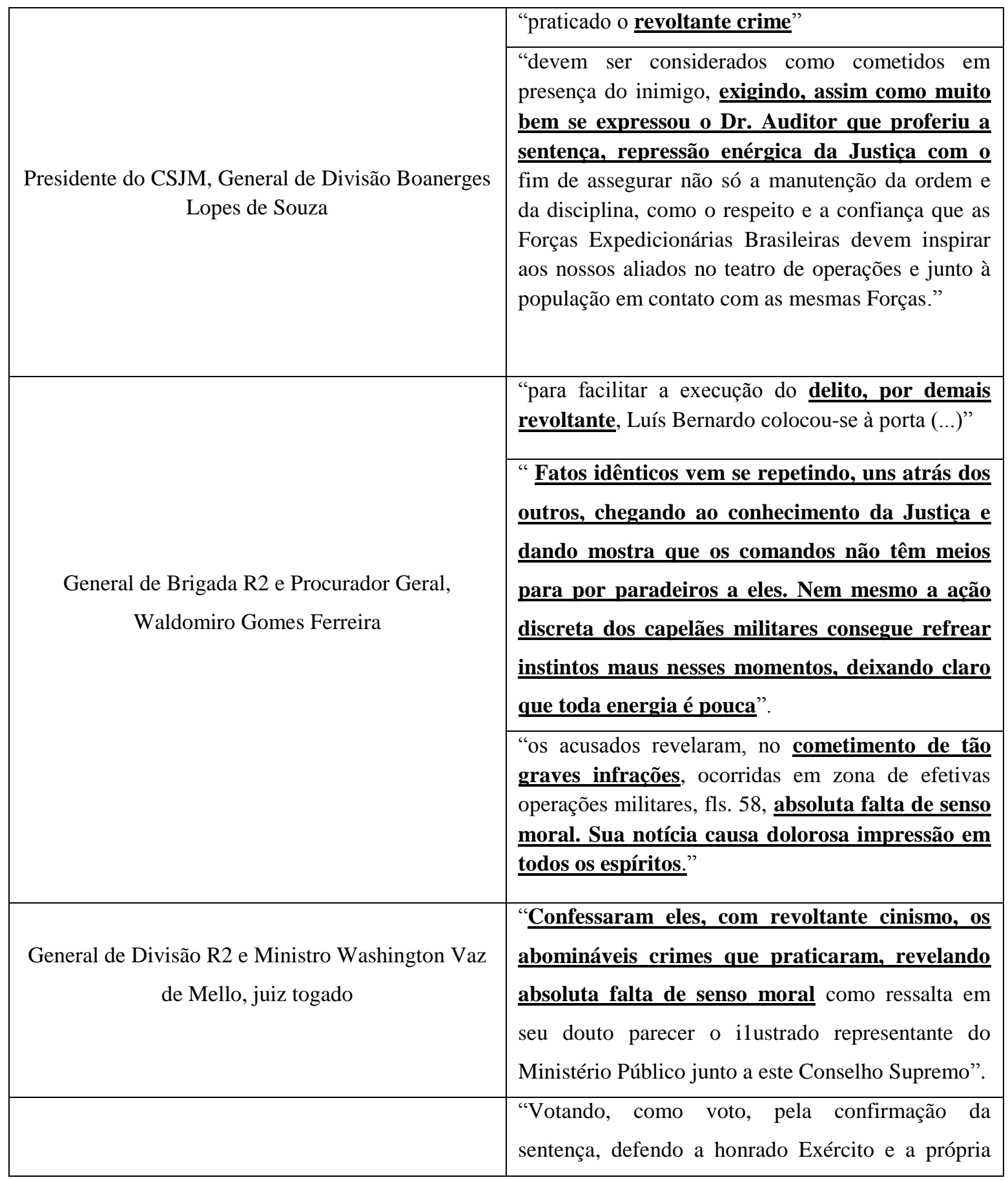




\begin{tabular}{|l|l|}
\hline General de Brigada, Francisco de Paula Cidade & $\begin{array}{l}\text { civilização brasileira. Não fossem os embaraços } \\
\text { opostos pela moderna legislação, estou certo de } \\
\text { que o comandante das forcas brasileiras na Itália }\end{array}$ \\
$\begin{array}{l}\text { teria, com grande proveito para a boa ordem de } \\
\text { suas tropas, feito fuzilar, sem quaisquer } \\
\text { delongas, esses criminosos". }\end{array}$ \\
\hline
\end{tabular}

Aqui, importante abrir um parêntese para ressaltar que nem o crime de delitos de violência carnal ${ }^{280}$, nem o crime de homicídio ${ }^{281}$, previam em seus tipos a pena de morte. A sentença, em verdade, despreza a pena decorrente da violência carnal, ao afirmar que o homicídio cometido para assegurar a execução da violência carnal -“absorve a pena decorrente da prática deste delito, uma vez que não resultou o falecimento do agente passivo"--.

A aplicação da pena capital se deu, portanto, em razão de um conjunto de fatores, dentre os quais citam-se (i) as agravantes de terem cometido os delitos em estado de embriaguez, com emprego de armas de serviço procuradas para aquele fim, e em país estrangeiro (art. 59, II, letras c, b e n, do CPM); (ii) bem como em razão do fato supostamente ter sido realizado em local de "zona de efetivas operações militares" e, ex-vi do art. 318 do $\mathrm{CPM}^{282}$, "considerado como cometidos em presença do inimigo" --em que pese os fatos terem ocorrido na cidade de Madgonana, vilarejo próximo à Porreta-Terme, cidade na qual estava o Pelotão de Defesa do QG da $1^{\text {a }}$ D.I. E onde os soldados estavam lotados, e que, ademais, caracterizava-se por ser órgão de retaguarda, no qual não havia os embates do front--.

Assim, a pena capital lhes foi aplicada com fulcro no art. 302, III, combinado com o artigo $181, \S 2^{\circ}, \mathrm{V}$, do CPM, que preconizavam, in verbis:

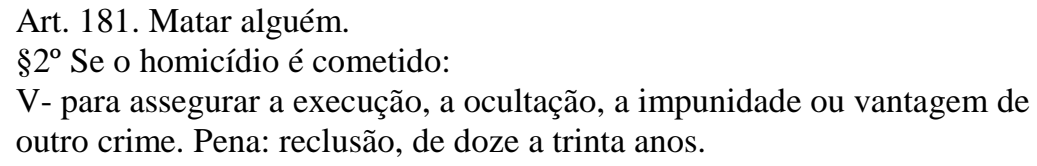

\footnotetext{
${ }^{280}$ Art. 192, do Código Penal Militar de 1944: Constranger mulher a conjunção carnal, mediante violência ou grave ameaça. Pena- reclusão, de três a oito anos.

${ }^{281}$ Art. 181, do CPM/44. Matar alguém: $§ 2^{\circ}$. Se o homicídio é cometido: V- para assegurar a execução, ocultação, a impunidade ou vantagem de outro crime. Pena- reclusão, de doze a trinta anos.

${ }^{282}$ Art. 318, do CPM/44. Diz-se crime militar praticado "em presença do inimigo" quando o fato ocorre em zona de efetivas operações militares, ou na iminência ou em situação de hostilidade.
} 
Consultando-se as fontes pesquisadas e elencadas ao final deste trabalho, pôde-se verificar que, de fato, o processo buscou obedecer a todas as formalidades legais. Quanto aos termos do julgamento, um tanto controversos, deram azo ao seguinte questionamento: se tantos casos semelhantes a esse ocorriam à época, qual o motivo de nesse, única e exclusivamente, ter havido condenação à pena de morte?

Na busca por uma explicação a essa questão, realizou-se um cotejo analítico em tópico subsequente, a partir de um estudo comparativo aos demais casos análogos ressaltados pelo General de Brigada R2 e Procurador Geral, Waldomiro Gomes Ferreira ao oferecer seu parecer pela condenação dos pracinhas.

Por enquanto, importa saber que se findou, dessa forma, o julgamento, pela Justiça Militar Expedicionária Brasileira, dos soldados Adão Damasceno Paz e Luiz Bernardo de Morais, condenados à pena de morte, que deveria ocorrer por fuzilamento.

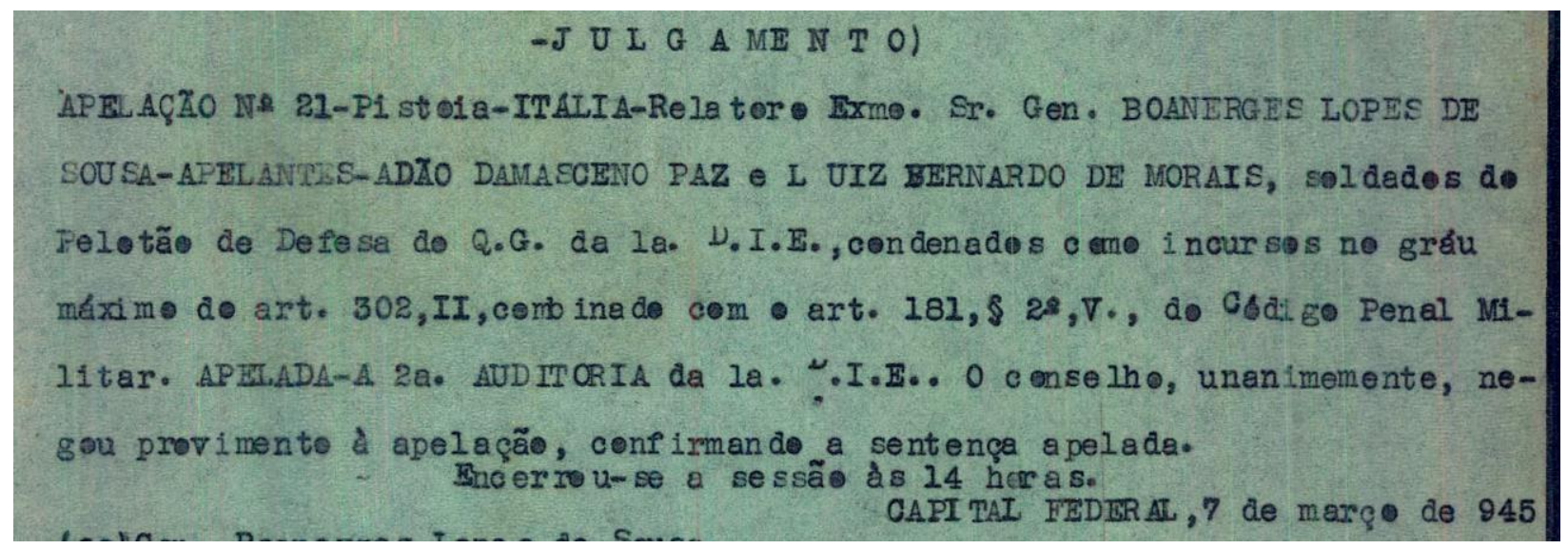

\section{CERTIDÃO}

Certifico que o soldado 1G-286.674, da Cia. do Q.G.,ADÃo DAMACENO PAZ, filho de João Medina Damaceno Paz e D. Izaura Damaceno Paz, com.26 anos de idade, natural do Estado do R10 Grande do Sul, $\theta$ o di to LUIZ BER NARDO DE MORA IS, $1 G-289.213$, tambem da Cia. do Q.G., filho de Lino Bemardo Dutra e D. Marla Candida Mora is, com 21 a nos de 1 dade, natural do Esta do do Rio Grande do Sul, de côr branca, foram condenados, por sentença dêste Juizo de 7 de fevereiro de 1945 , à pena maxima do artigo 302, III, combinado com o artigo 181, \$ $2 \%$, V, tudo do C.P.M., a qual fol conf1rmada por Acordão de 7 de mar ço do mesmo ano; que, por despecho do $\mathrm{E}_{x m}$ o Snr. Presidente da Repúbl ica, de 9.3 .1945 , fol a pena comutada, conforme rádio no $46 \mathrm{~F}$, transcrito no Bóletim Interno ne 75, de 16 do mesmo mês. Oértifico mais que os aludidos sentenciados foram recolhidos a PoIf́cla Militar da la. D.I.E., no dia 13 de janeiro de 1945 , data em que foram presos para investigações, conforme of 1c 1o ñ 372, de 12.2.1945, daquela Polícia. o que é verdade e dou fé. A canto namento em Pavana, Itál la, 12 de abril de 1945

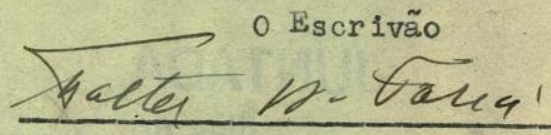




\section{(iii) O "fim da história".}

Não se tem, contudo, nenhum registro de execução, como cumprimento de pena de morte, ocorrida durante a $2^{\mathrm{a}}$ Guerra Mundial na documentação do Exército brasileiro.

Com efeito, uma vez confirmada a condenação pelo CSJM, os dois soldados foram embarcados, em julho de 1945, no navio brasileiro Pedro I, com outros 900 pracinhas, de volta ao Brasil. Durante a travessia oceânica eles ficaram sob a guarda da Polícia do Exército, que além dos soldados Adão e Luís, custodiavam outros 54 condenados $^{283}$.

Consoante o disposto no art. 29 do Regimento Interno ${ }^{284}$ que regulava a atuação do Conselho Supremo de Justiça Militar -“a sentença definitiva de condenação à morte será comunicada ao Presidente da República, logo que transitar em julgado, pelo Presidente do Conselho Supremo"--. Da mesma forma, o artigo 41 do Código Penal Militar de 1944 estipulava que a sentença condenatória que importasse na imposição da pena capital deveria ser comunicada ao Presidente da República logo após o seu trânsito em julgado, só podendo ser executada cinco dias depois da referida comunicação ${ }^{285}$.

Assim, em obediência aos preceitos expostos, o processo e o respectivo acórdão condenatório foram remetidos ao então presidente da República, Getúlio Vargas, a fim de que deliberasse quanto à pena de morte imposta.

Em consequência, ao ser comunicado do trânsito em julgado da pena de morte, o então Presidente da República, deixando claro que o fazia unicamente por ato de graça, comutou ambas as penas de morte, fixando-as na pena máxima de reclusão, ou seja, 30 anos. Nas suas palavras ${ }^{286}$ (Anexo n. 21):

"Se o Comandante em Chefe da FEB não considerou necessário mandar executar desde logo a pena, como lhe permitia o parágrafo único do artigo 41 do Código Penal Militar, se o exigisse o interesse da ordem e da disciplina militar,

\footnotetext{
${ }^{283}$ Relação completa no jornal carioca "Correio da Manhã”, pg. 9, edição de quarta-feira, 25 de julho de 1945. (disponível em: https://tokdehistoria.com.br/2013/02/page/2/. Acesso em 05.10.2016)

${ }^{284}$ Regimento Interno do Conselho Supremo de Justiça:

Art. $29^{\circ}$ - A sentença definitiva de condenação à morte será comunicada ao Presidente da República, logo que transitar em julgado, pelo Presidente do Conselho Supremo.

$\$ 1^{\circ}$ - Ressalvado o disposto no parágrafo único do art. 41 do Código Penal Militar, e após o transcurso do prazo de que trata o mesmo artigo, o Presidente do Conselho Supremo remeterá cópia da sentença ao Comandante-Chefe, que designará um oficial para cumpri-la, ou delegará essa atribuição ao comandante do corpo a que pertencer o condenado. $\S 2^{\circ}$ - Será juntada ao processo uma cópia da ata referente à execução da pena de morte.

${ }^{285} \mathrm{O} \S 1^{\circ}$ do mencionado artigo excepcionava o interesse da ordem e da disciplina, em zona de operações de guerra, quando a pena poderia ser imediatamente executada.

${ }^{286}$ Boletim Interno da $1^{\text {a }}$ D.I.E, $n^{\circ} 75$, de 16-III-945, ITEM XXII.
} 
é de se concluir que esse interesse e essa ordem não serão afetados com a comutação da pena. Esta, entretanto, só se justifica como ato de graça."

Nessa senda, por interferência do poder civil, a sentença não veio a ser executada, tendo sido publicado no Diário Oficial no 64 de 19 de março de 1945, a transcrição da comutação de pena dos praças condenados, restando expresso que:

"O Exmo. Sr. Presidente da República, por Decreto de 12 do corrente, resolve: Comutar para 30 anos de reclusão- Usando da atribuição que lhe confere o artigo 74, letra n, da Constituição, modificado pela Lei Constitucional $n^{\circ} 9$, de 28 de Fevereiro de 1945: A pena imposta pelo Conselho Supremo de Justiça Militar, em grau de apelação, aos soldados da $1^{\text {a }}$ Divisão de Infantaria Expedicionária ADÃO DAMASCENO PAZ e LUIZ BERNARDO DE MORAIS, como incursos no grau máximo do art. 302, III combinado com o Artigo 181, §2², V, do Código Penal Militar (Transcrito do B.I. n 65 , de 20-III1945, D.A."

Houve interesse da imprensa em melhor explorar o ocorrido. Por parte da imprensa nacional em território brasileiro, houve menção ao nome dos envolvidos no jornal "O Globo" (06.10.1945), no semanário "O Cruzeiro" e nos volumes 22 e 27 da Jurisprudência do Supremo Tribunal Militar. Destaca-se matéria no "Diário Carioca" (Anexo n. 22) que demonstra certa perplexidade com a comutação da pena. Também citase, aqui matéria veiculada pela "Revista da Semana" ${ }^{287}$, em 16 de julho de 1949, na qual é apresentada entrevista com os soldados, que tentaram se justificar acerca dos fatos à imprensa.

\footnotetext{
${ }^{287} \mathrm{Na}$ comentada reportagem, falha em termos de detalhes, Adão e Luís comentaram que a miséria na Itália era intensa e a fome estava impiedosamente presente entre os seus habitantes. Não por outro motivo, favores sexuais eram moeda corrente entre a população civil nativa para com os soldados aliados, em troca, principalmente, por alimentos, ou, também, pelo que fosse necessário.

Nesse cenário, segundo os dois pracinhas, as moças italianas, premidas pela necessidade, davam preferência aos soldados norte-americanos, mais ricos e com mais comida, o que suscitava irritação em soldados de demais nacionalidades.

Uma noite, em um dia de folga em meio às andanças do general Mascarenhas, segundo eles --"lá pelos lados de Porretta"--, informaram que passaram dos limites no consumo de álcool, facilmente encontrado. Nesse estado, afirmaram que havia uma casa onde eles sabiam que havia "jovens italianas" que costumavam sair com soldados da U.S. Army.

Alterados pela bebida, os dois rapazes se sentiram estimulados a procurarem essas mulheres a fim saciarem suas vontades sexuais, tendo para lá seguido, armados de submetralhadoras e desejosos de receberem os mesmos favores que eram dispensados aos americanos. Surpresas, as italianas não tiveram como reagir e durante meia hora os brasileiros praticaram várias sevícias contra elas.

Enquanto um violentava uma das vítimas, o outro ficava de guarda. Nisso, Luís teria ouvido um barulho e saiu para ver o que ocorria. Ao perceber que o vulto de um homem que se aproximava, metralhou a estranha figura.

Após novamente confessarem os fatos, afirmaram ter fugido pela praça principal deste lugarejo, próximo à cidade de Porreta, e correram por mais de meia hora, até terem a certeza de que não eram mais perseguidos. Contudo, o comentário do ocorrido no lugarejo foi intenso e em pouco tempo o pelotão da Polícia do Exército, incorporada à FEB e comandada pelo $1^{\circ}$ tenente José Sabino Maciel Monteiro, estava recebendo informações sobre a situação, às quais levaram à captura dos dois militares. Fonte: .http://tokdehistoria.com.br/2013/02/08/eles-desonraram-a-farda-da-forcaexpedicionaria-brasileira/(acesso em 06.03.2016 às 19h15)
} 
Já no teatro de operações, o 'Cruzeiro do Sul' ${ }^{\text {,28 }}$, uma das publicações de iniciativa dos pracinhas brasileiros, divulgou em sua $12^{\mathrm{a}}$ edição ${ }^{289}$, do dia 11 de fevereiro de 1945, a única menção à práticas criminosas por parte do Exército Brasileiro, em artigo intitulado "Condenados à Morte", onde está relatada a decisão de condenação à morte anteriormente retratada, sendo feita uma alusão à imensidão de atos nobres praticados pelos brasileiros, manchada pelo ato criminoso de dois militares brasileiros, consoante o seguinte texto:

\begin{abstract}
"Já é do conhecimento de todos o hediondo crime cometido por dois soldados brasileiros, em Granaglione, nos primeiros dias do mês passado.

Nossas colunas que estão abertas para a divulgação dos atos heroicos, dos feitos valorosos dos nossos expedicionários, não se mancharão para relatar crimes perpetrados por indivíduos indignos da nossa farda e da terra maravilhosa em que nasceram.

Apenas desejamos registrar o desfecho do horrível caso, para mostrar como se encontra vigilante a Justiça Militar da FEB, que não terá clemencia com os que tentarem conspurcar o nome do Brasil, a farda do Exército e o bom conceito que já conquistaram os nossos soldados neste continente, graças à conduta que vêm mantendo, quer na luta contra o inimigo, quer nas relações com a população civil italiana.

Julgando o processo que obedeceu a todas as formalidades legais, a Segunda Auditoria, através do Ten. Cel. Eugenio Carvalho Nascimento, houve por bem condenar, no dia 7 do corrente, os dois criminosos, Adão Damasceno Paz e Luiz Bernardo de Morais, à pena de morte, a única consentania com o crime cometido e com a responsabilidade que à Força Expedicionária cabe, de representar na Itália o nome, o prestígio e a honra da Nação Brasileira."
\end{abstract}

Dessa forma, vê-se a forma de repúdio como foi retrato o aludido crime, que, aliás, foi o único crime julgado pela Justiça Militar retratado nas páginas do Cruzeiro do Sul. É possível presumir que o Serviço Especial, numa tentativa de valorização da tropa, não tivesse intenções de divulgar atitudes criminosas perpetradas pela FEB, na medida em

\footnotetext{
${ }^{288}$ Sistematizada publicação de iniciativa dos pracinhas brasileiros, o Cruzeiro do Sul tinha seu conteúdo alinhado por seções hem compartimentas: 'O que vai pelo Brasil'; 'Noticiário Internacional'; 'A Guerra em 4 frentes'; 'Cartas do Brasil'; 'proclamações e mensagens de chefes militares nacionais e estrangeiros'; 'registro de ações relevantes'; 'notícias das unidades de todas as armas e serviços'; 'citações de combate' e 'condecorações'. Era escrito por expedicionários de todos os postos e patentes, e produzido nas dependências do Quartel-General da Divisão Expedicionária, embora sem conotação oficial. Nas unidades subordinadas, operando mais próximas ao contato com o inimigo, nos regimentos, batalhões, grupos, esquadrões, companhias, surgiram alguns pequenos jornais, mimeografados ou datilografados, tantos e tão diversos que não foi possível localizá-los e recuperá-los. Não foi só o 'Zé Carioca' que chegou a publicar cerca de cinquenta números, mas também 'E a cobra fumou', do $6^{\circ} \mathrm{RI}$; 'O Camelo e A Voz do Petrecho', de unidades de Infantaria; bem como o 'Só penas', da Engenharia de Combate.

Os principais colaboradores de 'O Cruzeiro do Sul' são os correspondentes de guerra, brasileiros e estrangeiros, assim como integrantes de Quartel-General e de outras unidades situadas mais à frente. Destacam-se o Cabo José César Borba, o Major Reynaldo Santana, o Major Souza Júnior, o Capitão Tácito Reis de Freitas, o Major Nelson de Carvalho, o Capitão Antorildo Silveira, o Tenente Amerino Raposo e o Soldado Jacob Gorender.

Cronistas notáveis, correspondentes de guerra, como Rubem Braga, do Diário Carioca; Joel Silveira, dos Diários Associados; Raul Brandão, do Correio da Manhã; Egydio Squeff, de 'O Globo'; Francis Hallawell, da BBC; Bagley, da 'Associated Press'; e ilustradores, como Scliar.

${ }^{289}$ O Cruzeiro do Sul. "Edição Comemorativa dos 30 anos da Poupex, dos 80 anos do Clube Filatélico do Brasil e dos 200 anos da Academia Militar das Agulhas Negras, Aman"/Roberto Mascarenhas de Moraes, organizador.- 2ed. Rio de Janeiro: Léo Christiano Editorial, Biblioteca do Exército, 2011. 240 pg.
} 
que houve, no mínimo, outros doze estupros cometidos por brasileiros durante a campanha na Itália, e nenhum deles está registrado nos 34 números de 'O Cruzeiro do Sul ${ }^{290}$.

O Coronel Ademar Barreto, Juiz da Justiça Militar, em depoimento ${ }^{291}$ que prestou à 'Memória da FEB', relata com precisão o ocorrido:

\begin{abstract}
“(...) prolata a sentença de morte, a sua execução devia ser imediata, como determinava a própria legislação. Acontece, porém, que a sentença tinha obrigatoriamente de ser comunicada ao Presidente da República. Em obediência a esse dispositivo legal, foi dada ciência ao Presidente da República que a execução da pena se impunha, como medida disciplinar e exemplo para a tropa, e também para limpar a nódoa que os dois soldados trouxeram às tropas brasileiras. Mas nessa altura funcionou o sentimentalismo brasileiro: o Presidente da República comutou a pena máxima para prisão perpétua, posteriormente atenuada aos 30 anos, até que foi reduzida, proporcionando aos condenados cumprir apenas seis anos".
\end{abstract}

O Marechal Mascarenhas de Moraes, Comandante da FEB, ao ter ciência dos motivos da comutação da pena, manifestou-se nos seguintes termos em radiograma ${ }^{292}$ :

\begin{abstract}
"Lamento que por má interpretação das leis não tenha sabido, eu, usar das atribuições que me competiam, mandando executar, por interesse da ordem e da disciplina, logo após julgamento do Auditor, os dois condenados, assassinos confessos, nocivos ao prestígio, disciplina, honra e dignidade da tropa brasileira perante Exércitos Aliados e população italiana. Interpretação acima devida do artigo 31 do Decreto-lei ${ }^{\circ}$ 6.396, de 01.04.1944, posterior ao CPM, o qual obrigando apelação na hipótese de todas as sentenças condenatórias, parece impedir aplicação ao parágrafo único do artigo 41 do CPM.",293
\end{abstract}

No final de 1945, com a desagregação do Estado Novo, descompressão da vida política e, valendo-se do clima de conciliação que imperava no Brasil, inclusive com concessão de anistia a presos políticos, o Executivo Federal editou o Decreto $n^{\circ} 20.082$, de 03 de dezembro de 1945, concedendo -“indulto aos oficiais e praças que, como parte

\footnotetext{
290 Maiores detalhes em: http://www.estadao.com.br/noticias/cidades,apos-estupro-soldados-brasileiros-foramcondenados-a-pena-de-morte, $921578,0 . \mathrm{htm}$.

${ }^{291}$ Depoimento do Coronel Ademar Barreto para o projeto “Memória da FEB”. In: SILVEIRA, p. 111.

${ }^{292}$ Em nota de Comando, expedida quando a Justiça Militar ainda funcionava em território italiano, o General Mascarenhas de Moraes teceu o seguinte comentário acerca de sua atuação: "A Justiça Militar da FEB, em todos os degraus da sua hierarquia e atividade, do juízo de $1^{\mathrm{a}}$ entrância do Conselho Supremo, tem estado à altura do momento e da sua nobre missão. Vigilante e inflexível, imparcial e serena, meticulosa na elaboração processual, rígida nos seus julgamentos e exata e exemplar nas suas sentenças, a nossa Justiça Militar vem concorrendo eficientemente para que não se quebre a coesão moral da tropa que o Brasil mandou ao continente europeu, como legítima expressão do seu poder militar e como genuína representante dos princípios jurídicos, secularmente esposado e defendido pela sua nobre e invariável política internacional. Enquanto os nossos bravos soldados conquistam belos e imorredouros triunfos para as armas nacionais, a Justiça Militar da FEB vela permanentemente para que se não empane o brilho da nossa atuação nestes campos de batalha e nem de leve esmaeça o colorido do prestígio e do conceito que já conquistamos, mercê do valor dos nossos homens e da compreensão nítida das nossas responsabilidades. À Justiça Militar da FEB, incansável sentinela da lei, rendemos hoje o preito da nossa admiração, pelo valioso e patriótico trabalho que vem realizando na defesa das nossas tradições de cultura e cavalheirismo e pelo maior e mais puro prestígio do Exército do Brasil. Nota de Comando $\mathrm{n}^{\circ}$ 20, de 30 de abril de 1945, publicada no Boletim Interno $\mathrm{n}^{\circ}$ 126, da $1^{\mathrm{a}} \mathrm{DIE}$, de 06 de maio de 1945.

${ }^{293}$ Boletim Interno da $1^{\text {a }}$ D.I.E, $n^{\circ}$ 75, de 16-III-945, Item XXIII.
} 
integrante da FEB, na Itália, haja cometido crimes que não os de homicídio doloso ou de deserção para o inimigo, tenham sido ou não julgados e condenados"--, bem como para dois civis italianos que tinham sido condenados pela Justiça Militar.

Em consequência, apenas 04 condenados não foram beneficiados pelo indulto, a saber: os dois condenados à morte, que haviam obtido comutação da pena para 30 anos de reclusão, e outros dois condenados pela prática de homicídio doloso.

Dessa forma, Adão e Luís Bernardo tinham previsão de cumprimento de pena até o ano de 1975, data em que finalizariam os 30 anos, contados a partir da prisão preventiva iniciada antes mesmo da audiência de instrução e julgamento do processo:

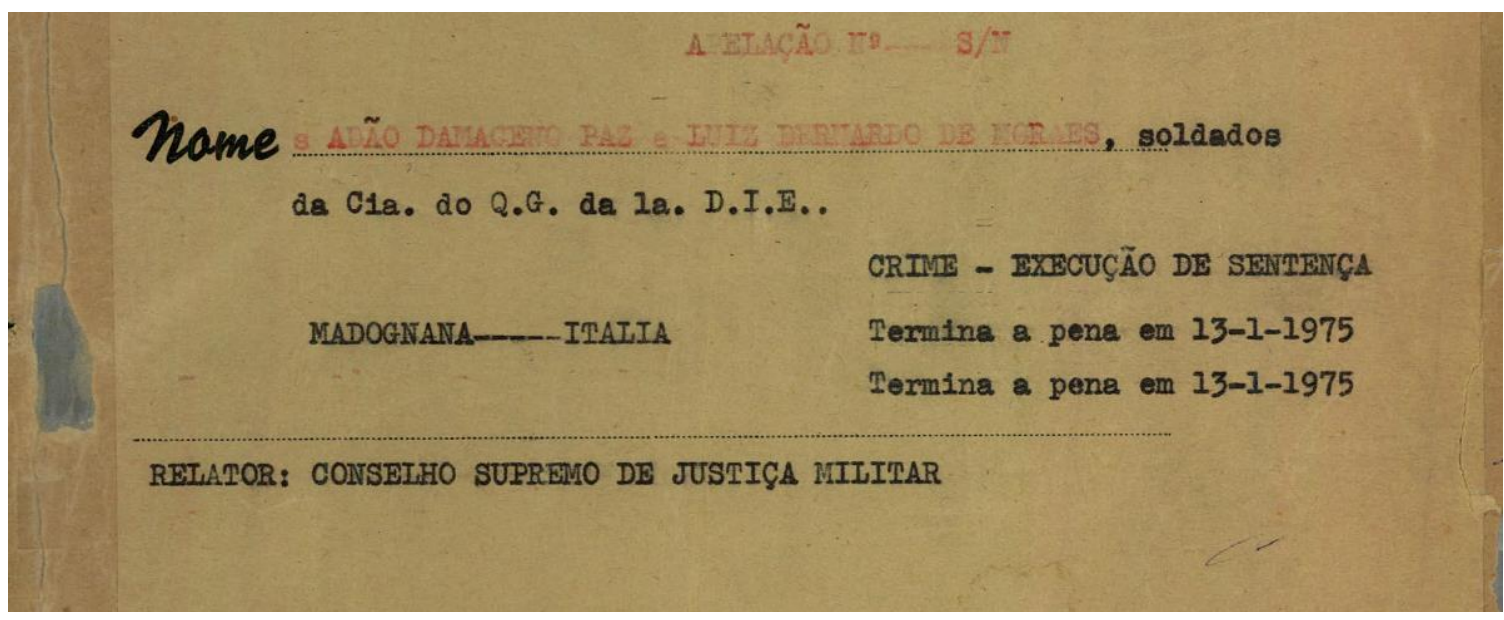

Solicito seja este Juizo informado, para efeito de comouto de tempo para execução de sentença, a data exáta em que foram presos para investigręões policiais, os soldados ADT̃O DANACENO PAZ e LUIZ BEFNARDO DE MORAIS, ambos da Cir. do Q.G..

$$
\text { SEV } 45,0058
$$

WBF

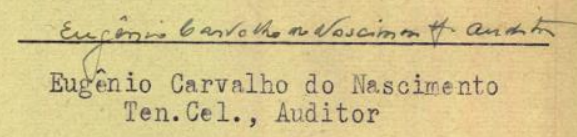

F.E.B. Acantonamento em Porretta Terme

Ia. D.I.E. Em 12 de Fevereiro de 1945 CHEFIA DE POLICIA 372/Rest. ne 11 Do Major Chefe do Serv.de Pol. Mil.. Ao Sr. Ten. Cel. Auditor da 2a. Auditoria.

Assunto: Informą̧ão(presta).

I- Restituo-vos o of. $n^{2} 69$ de 8-II-45, dessa Auditoria, informando-vos que os soldados ADĨO DAMACENO PAZ IUIZ BERNARDO DE MORAIS, foram recolhidos ao zadrez do Pelotão de Policia no dia 13 de Janeiro do eorrente âno às 16.30 (dezeseis e trinta) horas.
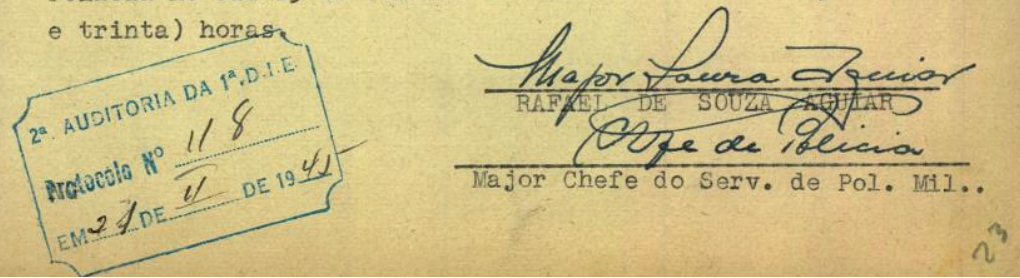
O Decreto-Lei n. 8.443, de 26 de dezembro de 26 de dezembro de 1945 (Anexo n. 8) extinguiu a Justiça Militar Expedicionária, transferindo a sua competência às Auditorias da $1^{\text {a }}$ Região Militar (Rio de Janeiro) (1 ${ }^{\mathrm{a}}$ instância) e ao Supremo Tribunal Militar (2 Instância).

Adão Damasceno e Luís Bernardo, não contemplados pelo indulto, cumpriam os 30 anos de pena que fora comutada por Vargas, na então Penitenciária Central do Distrito Federal ${ }^{294}$, antiga Casa de Correção, que em 1957 seria batizada como Penitenciária Lemos de Brito.

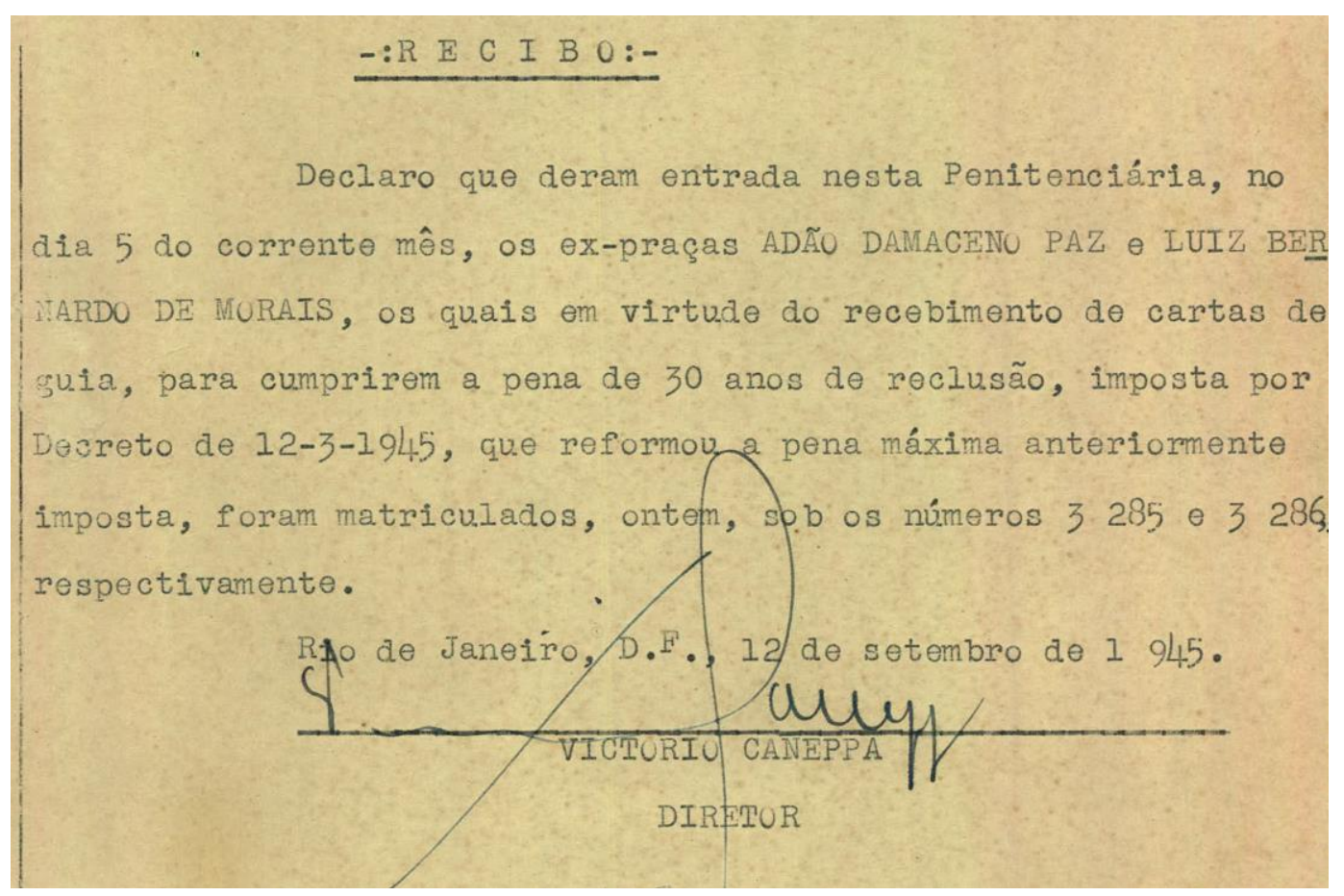

Ambos tinham bom comportamento na Penitenciária. Eram respeitados pelos companheiros de cadeia e não criavam problemas. Como mostra de boa conduta naquele recinto penitenciário, ambos ostentavam um distintivo no formato de estrela que envergavam no peito ${ }^{295}$, cedido pela própria Penitenciária Lemos de Brito.

Por essa razão, em 1949 eles aguardavam um indulto presidencial que havia sido positivamente recomentado pelo Conselho Penitenciário do Distrito Federal. A esse respeito, convém salientar que, na data de 04 de março de 1948, relatando pedido de graça em favor de Adão e Luís Bernardo no Conselho Penitenciário do Distrito Federal, Roberto Lyra exarou o seguinte parecer ${ }^{296}$, que lhes foi favorável e recebeu posterior acolhida:

\footnotetext{
${ }^{294}$ O antigo Distrito Federal, depois Estado da Guanabara e, hoje, capital do Estado do Rio de Janeiro.

295 https://tokdehistoria.com.br/2013/02/08/eles-desonraram-a-farda-da-forca-expedicionaria-brasileira/, acesso em 01.05.2016, às 19h40.

${ }^{296}$ Roberto Lyra; Direito Penal normativo; p. 167-173.
} 
"Depois da guerra, a política criminal afeiçoou-se às legítimas efusões da vitória, justificando a indulgência plenária que alcançou até, a meu ver, indefensavelmente, aos inimigos. Apenas aos agraciados deixou de favorecer. A legenda épica, que também lhes pertence, não preteriu a mácula que eles são os primeiros a deplorar. Crimes dolosos, inclusive contra a vida, foram perdoados (Decreto $\mathrm{n}^{\circ}$ 20.082, de 03 de dezembro de 1945), subsistindo somente os praticados pelos agraciandos e que, dissociados, iniquamente, do quadro da guerra, são repugnantes. Entretanto, diluídos nos seus horrores elementares, perdem a exorbitância (...) Porque a 'ferocidade dos instintos mais baixos' há de ser cobrada apenas aos agraciandos? (...) Os agraciandos têm personalidade e antecedentes que se opõem aos fatos só explicáveis pela brutalidade e pela licença da guerra. É o espetáculo do seu procedimento que impressiona a epiderme psicológica, mas, exatamente, essa insólita singularidade evidencia o divórcio, a vínculo entre o aberrante desregramento e toda a vida dos agraciandos. Entre nós, a comutação da pena de morte para o máximo genérico da privação de liberdade não significa clemência. É 'norma aconselhável' de política criminal comum. Portanto, a bem dizer, os agraciandos não foram, até agora, beneficiados pela política criminal excepcional aplicada aos exexpedicionários. O pedido de clemência é incompatível com as inclemências da receptividade. Seria, pois, absurdo, examinar esta súplica, circunscrever o relatório às aparências, reproduzindo a implacabilidade dos critérios de emergência que, se justificados na provação histórica de nossos soldados nos combates da Europa, não se harmonizam ao julgamento do orgulho cívico e da gratidão patriótica. Os agraciandos foram punidos, e a graça não apaga o crime, não anula, não revê a condenação que subsiste como protesto de nossa consciência moral e como satisfação aos respeitáveis sofrimentos da ofendidas (...)."

Assim, sobreveio a edição do Decreto de 30 de maio de 1951, em $1^{\circ}$ de junho

de 1951. Os últimos condenados pela Justiça Militar que ainda cumpriam pena, foram, enfim, libertos da Penitenciária Central do Distrito Federal ao serem beneficiados com nova comutação de pena, que reduziu suas penas de 30 para 06 anos de reclusão:

"Atendendo a que os sentenciados LUIZ BERNARDO DE MORAIS e ADÃO
DAMASCENO PAZ já cumpriram mais de 6 anos e 3 meses de 30 anos de
reclusão, para quanto foi comutada, por decreto de 12 de março de 1945 , a pena
de morte, a que foram condenados, como incurso no art. 302, III, combinado
com o art. $181, \$ 2^{\circ}, \mathrm{n}$. V, do Código Penal Militar, por sentença da $2^{\text {a }}$ Auditoria
da $1^{\text {a }}$ Diretoria de Intendência do Exército, confirmada por Acórdão do
Conselho Superior de Justiça Militar:
Resolve, usando da atribuição que lhe confere o art. 87, n. XIX, da
Constituição, comutar a mencionada pena para 6 anos de reclusão.
Rio de Janeiro, em 22 de maio de $1951,130^{\circ}$ da Independência e $63^{\circ}$ da
República."

Defronte ao novo decreto presidencial, a Auditoria competente para zelar pela execução da sentença, houve por bem, em 01.06.1951 (Anexo n. 26) se manifestar pela extinção da punibilidade dos réus (já haviam cumprido pena maior do que os 06 anos estipulados pela segunda comutação com a qual foram beneficiados), consoante os termos que se seguem: 
"Pela respeitável sentença do tenente coronel auditor da $2^{\mathrm{a}}$ Auditoria da $1^{\mathrm{a}}$ Divisão de Infantaria Expedicionária, proferida em tempo de guerra, no acantonamento em Pistoia (Itália), a 7 de fevereiro de 1945, confirmada em grau de apelação, sem discrepância de votos, pelo venerando acórdão de 7 de março do mesmo ano, do Conselho Supremo de Justiça Militar, foram condenados à pena de morte, como incursos no art. 302 n. III combinado com o art. $181, \S 2^{\circ}$ n. V do C.P.M., os soldados do Pelotão de Defesa da Cia do QG Avançado, Adão Damasceno Paz e Luiz Bernardo de Morais- fls. 7 e 17.

O Presidente da República, porém, no uso de atribuição constitucional, houve por bem comutar, por decreto de 12 de março daquele ano, a pena para 30 anos de reclusão. E, agora, por decreto de 22 de maio p.p, para 6 anos, com fundamento no art. 87 n. XIX da Constituição- fls. 22 e 64. Ouvido, na forma da lei, o digno representante do M.P, declarou que nada tem a opor. Insurgiu-se, porém, com justa razão, por ter sido tomada, no decreto de indulto, junto por cópia da $1^{\mathrm{a}}$ Divisão de Infantaria Expedicionária, "a gloriosa força armada que tão alto elevou o nome do Brasil”, pela $1^{\text {a }}$ Diretoria de Intendência do Exército (I)- fls. 64 e 65 .

Apura-se, como se vê da certidão de fls. 61v., que os sentenciados já cumpriram até a presente data, a pena de reclusão de 6 anos, 4 meses e 19 dias.

Ajustando, frente ao exposto, a execução da pena nos termos do decreto presidencial, declaro extinta a punibilidade do fato criminoso, com o cumprimento da pena de 6 anos de reclusão a que ficou reduzida a de 30 anos (art. 104 n. II do CPM). Expeça-se, assim, alvará de soltura a favor dos sentenciados Adão Damasceno Paz e Luiz Bernardo de Morais, e cumpram-se as demais formalidades de praxe".

Por conseguinte, ante ao reconhecimento por parte do Estado, da extinção de seu poder punitivo face aos delitos perpetrados pelos réus, estes foram postos em liberdade; não tendo havido a execução dos condenados:

Comunico a Vossa Excelência, para os devi-

dos fins, que ADÃO DAMASCENO PAZ, RG. 67 404, matricula n 3285 ,

foi pôsto em liberdade no dia 1 de junho corrente, em cumprimento

do alvará de soltura expedido no dia 1 de junho corrente.

Comunico a Vossa Excelência, para os devi-

dos fins, que LUIZ BERNARDO DE MORAIS, RG. 67 403, matricula no

3 286, foi pôsto em liberdade em cumprimento do alvará de soltu-

ra expedido no dia 1 de junho corrente.

Segundo a reportagem ${ }^{297}$ de Leonencio Nossa, os dois ex-soldados da FEB morreram na década de 1990. Consta que Adão vivia solitário, andava com dificuldades. Anos depois da guerra, foi acusado de furto. Na audiência, o juiz perguntou se já havia sido processado: "Fui condenado à morte". O juiz se assustou: “Que história é essa? Brasil não tem pena de morte".

\footnotetext{
${ }^{297}$ http://brasil.estadao.com.br/noticias/geral,apos-estupro-soldados-brasileiros-foram-condenados-a-pena-demorte, 921578 (acesso em 01.05.2016, às 20h43).
} 


\section{(iv) Estudo comparativo face a casos análogos.}

Na história da Força Expedicionária Brasileira em campo de combate italiano, ocorreram casos desabonadores, dentre os quais crimes sexuais que chegaram a assustar a população italiana. Verifica-se, a partir das sentenças proferidas pela Justiça da FEB, que os principais delitos sexuais julgados foram o estupro e o uso de violência para forçar a conjunção carnal. Contudo, destaca-se que, comparativamente, aos demais delitos cometidos pelos expedicionários, não foram muitos os crimes sexuais relatados.

Há diversas hipóteses que podem ser aventadas para esse número relativamente reduzido de julgados referentes aos delitos sexuais. Inicialmente, convém aclarar que os favores sexuais eram moeda corrente entre a população civil para com os soldados aliados, em troca, principalmente, por alimentos, ou pelo que fosse necessário dentre os gêneros de primeira necessidade.

Sem se prestar a sair em defesa de atitudes delituosas, convém rememorar que a tropa brasileira saiu para a guerra sem muita instrução, sendo muitos soldados de regiões interioranas do país e de escolaridade precária. Ao chegarem em solo italiano, se depararam com um país que se passava por imensa dificuldade financeira. Nesse cenário, via-se nas ruas, em plena luz do dia, homens oferecendo sexo das filhas ou esposas como moeda de troca por comida ou cigarro, artigo diferenciado à época.

Assim, para quem quisesse, o sexo era fácil e sem muitas restrições, como abordado em depoimento ${ }^{298}$ de Eronides João da Cruz, ex-componente da FEB:

\footnotetext{
“A guerra é a maior desgraça, porque quem sofre mais é a população civil, que não tem nada a ver com a situação, isso acaba gerando uma situação de miséria tal que a prostituição vira um meio de sobrevivência, onde o próprio pai acaba negociando a filha. Como eu tive a oportunidade de falar para um pai, mas essas são suas filhas, o senhor veio aqui negociar elas, e o pai me respondeu, sim e vamos fazer o que, morrer de fome? As mulheres eram de 12 a 60 anos, todas as idades, eu jamais me aproveitei de qualquer mulher que seja, mas vi muitos que se aproveitavam dessa situação. Se trocava sexo por chocolate mesmo".
}

Relatos assim prenunciavam que as consequências da guerra afetavam pessoas de todas as idades. Atitudes julgadas como alarmantes em tempo de paz, se tornavam corriqueiras durante a deflagração de conflitos armados. $\mathrm{O}$ ato sexual, portanto, era considerado mercadoria de troca, dada a miséria e a devastação causadas pela guerra, conforme explica o ex-combatente da FEB, Lindolfo Guilherme Arendt ${ }^{299}$ :

\footnotetext{
${ }^{298}$ In. Depoimentos dos Oficiais da Reserva sobre a FEB. São Paulo: IPE, 1949.

${ }^{299}$ Idem.
} 
“(...) outra coisa que era muito comum de se presenciar era a troca de sexo por uma carteira de cigarro, uma barra de chocolate, dava até pena de se ver aquelas meninas de 11, 12, 13 e 14 anos se oferecendo para sexo, essa é uma verdade."

O padre Inocêncio, capelão do $6^{\circ}$ Regimento de Infantaria, comentou algumas das maneiras de contato entre militares e mulheres civis. Inocêncio, quando do período de estacionamento da tropa em Francolise, no sul da Itália, censurou gravemente o comportamento de uma parcela da FEB. Referindo-se ao tédio que imperava no acampamento, expôs que uma solução dos soldados para enfrentá-lo consistia na seguinte prática:

\begin{abstract}
“(...)Muitos, porém, demandavam às lagoas vizinhas, onde o refrigério do corpo pela banho era ocasião e pretexto para a mais desenfreada bacanal. Ali pululavam as rameiras. Passemos de largo pela triste página de corrupção moral que os soldados brasileiros abandonados na Itália escreveram em Francolise. Cem quilômetros ao sul, além de Nápoles, contornado o Vesúvio, jazem as ruínas de Pompéia antiga, testemunhas mudas de pavorosa tragédia. Mutismo eloquente! Vê-se claramente que toda aquela cidade, estuante de vida em seus tempos áureos, não passava de imenso lupanar! O turista que reflete deixa aquela imensa sepultura convencido de que o vulcão enfurecido foi o gládio de fogo vibrado por Deus, numa repetição do castigo de Sodoma. Pois bem, aquele céu da Itália jamais terá presenciado cenas tão degradantes quanto as que, com os pracinhas brasileiros, se desenrolaram entre as colinas de Francolise. Basta dizer que o mulherio acorreu de toda a Itália, sem excluir a Lombardia e Veneza. Em cada operação de "limpeza" centenas delas eram arrebanhadas. Era só o trabalho de levá-las para bem longe e esperar. Voltavam.",300
\end{abstract}

Nesse cenário de corrupção moral, como alardeado pelo Padre Inocêncio, verifica-se que, os estabelecimentos de prostituição, localizados nas grandes cidadescomo Pistoia, Roma, Nápoles e Florença. Contudo, a audácia sexual dos soldados ia além; concretizavam suas necessidades com mulheres do campo e das montanhas, que se dispunham realizar favores sexuais em troca de víveres, sobretudo em certos pontos de retaguarda, onde esse contato era facilitado ${ }^{301}$.

Ratificando a hipótese de que esses casos, tinham origem, nas mais diversas vezes, na displicência dos serviços de retaguarda, ambiente propício ao desfalecimento moral, apresenta-se o relato do $1^{\mathrm{o}}$ Tenente R2 de Infantaria, José X. Góis de Andrade, segundo o qual:

“(...) Os chamados serviços de retaguarda, organizam-se em vilas e cidades, pela maior facilidade de instalações. Aí é que começam os perigos do que

\footnotetext{
${ }^{300}$ Idem, p. 400.

${ }^{301}$ MAXIMIANO, César Campiani. Barbudos, sujos e fatigados: soldados brasileiros na Segunda Guerra Mundial. São Paulo: Grua, 2010. p. 323.
} 
chamarei - instalação doméstica da retaguarda. O homem procura familiarizarse com o ambiente, instalar-se domesticamente.

Ora, numa guerra, a população local sofre as consequências mais variadas. $\mathrm{Na}$ Itália, grande parte dos homens ausentes, deslocados, prisioneiros, aumento ainda mais a desproporção entre o número de pessoas do sexo feminino geralmente maior e o do sexo masculino, acentuadamente entre os vinte e trinta e cinco anos. Havia falta de certos gêneros essenciais, como gorduras, chocolates, doces, etc., sabão, açúcar, café, couros e sapatos e tecidos, gasolina e outros produtos não vitais, mas de que os povos civilizados sentem a falta no conforto cotidiano, principalmente as mulheres, como perfumarias (baton (sic), pós, sabonetes, talco, etc). O combatente começa por se aproximar das casas, pela curiosidade humana de conhecer aquela gente, saber o que houve, como agiu o inimigo, quais os seus hábitos, etc. Conversa com os velhos mais acessíveis, alisa a cabeça das crianças (o combatente torna-se sentimental. Hajam (sic) vista as fotografias que leva consigo. Os prisioneiros alemães, tinham em seus bolsos inúmeras fotografias de suas famílias. O mesmo acontecia com os americanos e em ponto menor com os brasileiros). Oferece caramelos e chocolates ou conservas de suas rações. Surge, então, a mulher desejada (...) e aí começa a história (...)".302

Assim, a corrente prática de se oferecer o sexo como moeda de troca pode ser encarada como uma das razões pelas quais a incidência de crimes de violência sexual foi considerada pequena, comparativamente aos demais delitos presentes na estatística da $\mathrm{FEB}^{303}$.

A título hipotético, poderia suscitar-se, também, o menor nível de proteção jurídica e de percepção masculina do direito das mulheres sobre o próprio corpo. Nesse sentido, convém consignar que a igualdade de direitos entre homens e mulheres, em documento internacional, é reconhecida apenas em 1945, através da Carta das Nações Unidas. No Brasil, a seu turno, somente com o advento da Constituição de 1967, elaborada após a Declaração Universal dos Direitos do Homem, é que restou fixada, textualmente, a igualdade de todos perante a lei, sem distinção de sexo ${ }^{304}$.

Outra razão que poderia aqui ser elencada, é a suposição de que eventuais punições aos responsáveis por essas violências sexuais fosse visto como pelas autoridades da FEB como uma "desmoralização", ao demonstrar que os pracinhas não seriam apenas bons combatentes, como a propaganda oficial apresentava.

Essa hipótese ganha mais força ao se verificar o 'silenciamento' promovido pelos órgãos judicantes em relação a fatos dessa espécie. Não se está manifestando aqui que tais atitudes eram intencionais. Apenas se visa demonstrar que alguns dos casos

\footnotetext{
${ }^{302}$ Depoimento de Oficiais da Reserva sobre a FEB, p. 373.

${ }^{303}$ Trata-se aqui de oferecer uma explicação para o reduzido número de crimes sexuais julgados, e não uma justificativa para os delitos sexuais perpetrados pelos pracinhas.

${ }^{304}$ Emenda Constitucional n. 1, de 1969 (art. 153, §1 ): “Todos são iguais perante a lei, sem distinção de sexo, raça, trabalho, credo, religiosos, e convicções políticas. Será punido pela lei o preconceito de raça".
} 
levados ao conhecimento das autoridades não tiveram a continuidade e o julgamento com rigor que se demonstrou no caso detalhado no tópico anterior.

Nesse sentido, apresentam-se, a título exemplificativo, os seguintes arquivamentos dos cadernos investigativos promovidos:

\section{INQUÉRITO POLICIAL MILITAR No 13}

Estupro praticado em uma menor. Arquiva-se o Inquérito por não ter sido identificado o autor do crime.

Relator: General Boanerges Lopes de Sousa.

Remessa: Da $2^{\mathrm{a}}$ Auditoria da $1^{\mathrm{a}}$ D.I.E.

Vistos, examinados e discutidos os presentes autos do qual foi encarregado o Cap. ALOYSIO GONDIM GUIMARÃES, do Depósito do Pessoal, para apurar o autor do estupro da menor LUCIANA PALIETTI, resolvem, unanimemente, os Juízes do Conselho Supremo de Justiça Militar, mandar arquivar os autos do mesmo Inquérito, por não ter sido identificado o criminoso.

Capital Federal, 7 de maio de 1945.

\section{INQUÉRITO POLICIAL MILITAR N 20}

Inquérito. Arquiva-se o inquérito por inexistência de crime.

Relator: General Washington Vaz de Mello.

Indiciado: J.S., soldado da $2^{\mathrm{a}}$ Cia. Eng. Do $9^{\circ}$ B.E

Remessa: Da $1^{\text {a }}$ Auditoria da $1^{\text {a }}$ D.I.E

No dia 23 de março deste ano, durante uma festa dançante que se realizava na casa $n^{\circ} 122$ da localidade de Valdibura (Pavana), o indiciado foi visto, no $2^{\circ}$ andar, com uma menor de 6 anos, sendo-lhe atribuída a intenção de embriaga-la para, com ela, praticar atos de libidinagem.

Zini Maria, tia da referida menor, declara que esta descia a escada e que lhe dissera tê-la colocado o indiciado sobre os joelhos e lhe dado vinho e chocolate (...)

$\mathrm{O}$ indiciado nega o fato, dizendo que estivera no $2^{\circ}$ andar à espera de Zini Maria, com quem ia ter conjunção carnal (...).

Efetivamente, não ficou provada a grave imputação feita ao soldado S.E.F. quando houvesse ele ofertado chocolate e vinho à menor, tais atos não poderiam ser considerados início de execução do delito de conjunção carnal, ou idôneos e inequívocos (...).

Em tais condições, acordam os Juízes do Conselho Supremo de Justiça Militar em deferir, como deferem, o pedido de arquivamento do presente inquérito.

Capital Federal, 11 de junho de 1945.

\section{INQUÉRITO POLICIAL MILITAR No 26}

Libidinagem. Quando não constitui crime.

Relator: General Heitor Augusto Borges.

Indiciado: $2^{\circ}$ Tenente R/2, J. B.F.

Remessa: Da $2^{\text {a }}$ Auditoria da $1^{\mathrm{a}}$ D.I.E

Vistos e relatados estes autos de inquérito, em que figura como indiciado o $2^{\circ}$ Tenente da Reserva de $2^{a}$ classe, J.B.F., contra quem pesa a acusação de prática de atos de libidinagem, acordam os Juízes do Conselho Supremo de Justiça Militar, em determinar a remessa dos autos ao Exmo. Sr. Dr. Procurador Geral da Justiça Militar, nos termos do parecer de fls. 56 a 57, que adotam como razões de decidir.

Capital Federal, 27 de novembro de 1945.

Destarte, relatos atestam o quão triste e chocante a alguns, era ver o pai dando a filha por comida e cigarro. Muitas das vezes os soldados davam o cigarro e não queriam 
o sexo. Talvez a maioria tenha feito isso, mas quantos será que não fizeram o contrário? A despeito do cenário de desfalecimento moral apresentado, pracinhas ainda foram responsáveis por forçarem italianas a fazerem sexo com eles, incidindo nos delitos de estupro ou constrangimento para realização de conjunção carnal, quando não conseguiam concretizar o ato.

Decerto, quando esses casos, quando noticiados, não eram silenciados, promovia-se a apuração dos fatos, a fim de que fossem julgados pela Justiça da FEB. Contudo, grande parte dos julgamentos promovidos pela Justiça Expedicionária ao sentenciarem crimes sexuais ocorreram de forma diferenciada à exposta no tópico anterior, não se vislumbrando a odiosa forma de repúdio, demonstrada pelos julgadores, que embasou a condenação à pena capital daqueles dois pracinhas. Nesse sentido, vejamos:

\section{Tabela 10: Casos análogos apenados de forma distinta}

\begin{tabular}{|c|c|c|c|}
\hline Autores & Denúncia & Sentença & Condenação Final \\
\hline $\begin{array}{l}\text { C.P.B, Soldado da } \\
3^{\text {a }} \text { CIA do } 1^{\circ} \\
\text { Grupo do } 1^{\circ} \\
\text { Regimento de } \\
\text { Artilharia Pesada } \\
\text { Curta }\end{array}$ & $\begin{array}{l}\text { "Na estrada que liga Pisa ao } \\
\text { acampamento da FEB, o acusado, } \\
\text { aproximando-se da senhora } \\
\text { Balestra Eletra, nonagenária, de } \\
\text { nacionalidade italiana, sob o } \\
\text { pretexto de examinar um anel, } \\
\text { convidou-a para a prática de } \\
\text { conjunção carnal e como fosse } \\
\text { repelido, empurrou a referida } \\
\text { senhora para uma vala, pisando-a e } \\
\text { dando-lhe pontapés". }\end{array}$ & 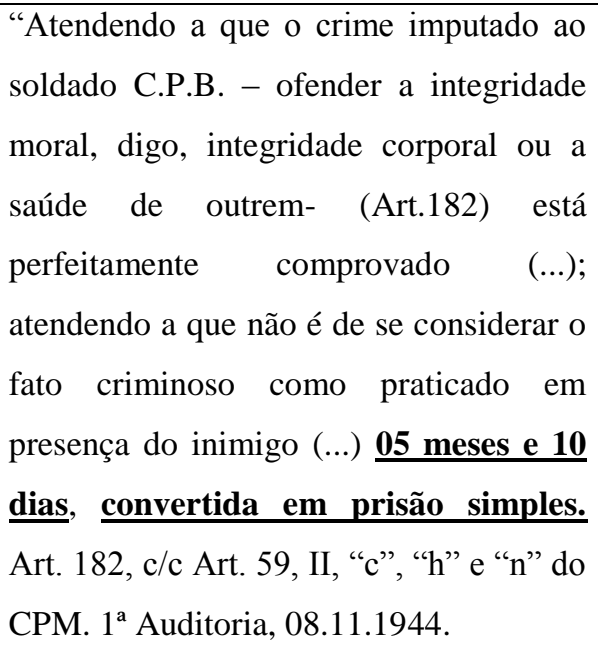 & $\begin{array}{l}\text { APELAÇÃO } \mathrm{N}^{\circ} 3- \\
\text { PISA- ITÁLIA } \\
\text { “Acordam os Juízes do } \\
\text { Conselho Supremo de } \\
\text { Justiça Militar, por } \\
\text { unanimidade de votos, } \\
\text { negar provimento à } \\
\text { apelação para } \\
\text { confirmar a sentença } \\
\text { apelada”. } \\
\text { Nápsoles, 24.11.1944. }\end{array}$ \\
\hline F.A.M, Soldado & $\begin{array}{l}\text { "No caminho que liga a localidade } \\
\text { de Badi a Ponte de Treviana, o } \\
\text { acusado encontrou Belostri Liduina, } \\
\text { chamou-a por três vezes e como } \\
\text { não fosse atendido, aproximou-se, } \\
\text { agarrando-a, jogando-a a uma vala, } \\
\text { procurando com a mão tapar-lhe a } \\
\underline{\text { boca e tentou manter com ela }} \\
\underline{\text { conjunção carnal. Como a mesma }} \\
\text { debatia-se e pedia socorro, atacou-a } \\
\underline{\text { a socos, causando-lhe os ferimentos }}\end{array}$ & $\begin{array}{l}\text { "Atendendo ao que o crime atribuído ao } \\
\text { réu- tentativa de violência carnal, em } \\
\text { lugar de efetivas operações militares- não } \\
\text { se verificou ante a prova colhida (...) } \\
\text { Atendendo, porém, a que o acusado } \\
\text { confessa ter dado uns 'tapas' na senhora } \\
\text { italiana (...) condeno o soldado F.A.M a } \\
\text { seis meses de prisão simples, por julgá- } \\
\text { lo incurso no art. } 182 \text { c/c Art. 59, II, "n” } \\
\text { do CPM. } 1 \text { a Auditoria, } 13.03 .1945 \text {. }\end{array}$ & $\begin{array}{l}\text { APELAÇÃO } \mathrm{N}^{\circ} \text { 25- } \\
\text { PISTÓIA- ITÁLIA } \\
\text { “Acordam os Juízes do } \\
\text { Conselho Supremo de } \\
\text { Justiça Militar em } \\
\text { reformar a sentença } \\
\text { apelada para dar } \\
\text { provimento à apelação } \\
\text { da Promotoria, } \\
\text { condenado o réu F.A.M } \\
\text { à pena de um ano, }\end{array}$ \\
\hline
\end{tabular}




\begin{tabular}{|c|c|c|c|}
\hline & $\begin{array}{l}\text { descritos nos autos e só a } \\
\text { abandonou quando foi socorrida por } \\
\text { outra senhora" }\end{array}$ & & $\begin{array}{l}\text { quatro meses e quinze } \\
\text { dias de prisão simples". } \\
\text { CSJM, Capital Federal, } \\
\text { 09.04.1945. }\end{array}$ \\
\hline $\begin{array}{l}\text { A de F, J. M e } \\
\text { J.A.C, Soldados }\end{array}$ & 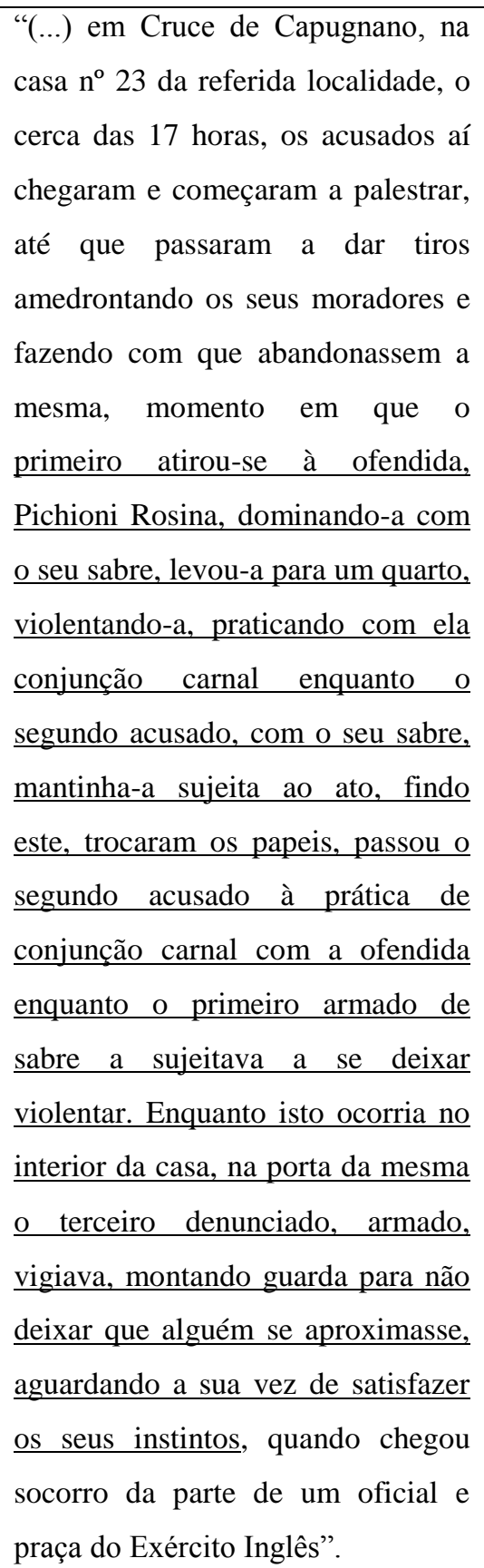 & $\begin{array}{l}\text { "os dois primeiros acusados, acima } \\
\text { mencionados, tiveram relações sexuais } \\
\text { com Pichioni Rosina, contra a vontade } \\
\text { desta (...) considerando que o crime } \\
\text { atribuído aos dito acusados foi praticado } \\
\text { em lugar de efetivas operações militares } \\
\text { (...) considerando que ocorreram as } \\
\text { agravantes do art. } 59 \text {, letras 'e' e 'n', II, } \\
\text { do CPM, respectivamente: 'depois de } \\
\text { embriagar-se e 'em país estrangeiro' (...) } \\
\text { condeno os soldados A. de F e J.M. a } \\
\text { seis anos e quatro meses de reclusão, } \\
\text { por julgá-los no art. } 312 \text { combinado com } \\
\text { o art. } 192 \text { do CPM. (...) Absolvo o } \\
\text { soldado J. A. C (...) ficou esclarecido } \\
\text { que o soldado J.A.C não dava } \\
\text { demonstração de estar vigiando a casa } \\
\text { em que ocorreram os fatos". } 1^{a} \\
\text { Auditoria. } 17.04 .1945 .\end{array}$ & $\begin{array}{l}\text { APELAÇÃO } \mathrm{N}^{\circ} \\
\text { PISTÓIA- ITÁLIA } \\
\text { "Considerando que a } \\
\text { sentença apelada foi } \\
\text { proferida de acordo } \\
\text { com a lei e a prova dos } \\
\text { autos; Acordam os } \\
\text { Juízes do Conselho de } \\
\text { Justiça Militar em } \\
\text { negar provimento às } \\
\text { apelações interpostas, } \\
\text { para confirmar, como } \\
\text { confirmam, a referida } \\
\text { sentença". CSJM, } \\
\text { Capital Federal, } \\
25.05 .1945 .\end{array}$ \\
\hline $\begin{array}{l}\text { Soldado P. A, o } \\
\text { Cabo H. do C. e, } \\
\text { o soldado M.P, } \\
\text { todos da Bateria } \\
\text { de Comando da } \\
\text { Artilharia } \\
\text { Divisionária }\end{array}$ & $\begin{array}{l}\text { "Na Casa Rosa, em Vila } \\
\text { Madognana, Comuna de } \\
\text { Granaglione, Itália, os acusados } \\
\text { chegaram em companhia do } 2^{\circ} \\
\text { Sargento Pavani e mantiveram com } \\
\text { os moradores amistosa palestra até } \\
\text { cerca das 24horas, quando se }\end{array}$ & $\begin{array}{l}\text { "Os documentos informam que os crimes } \\
\text { não se passaram em zona de efetivas } \\
\text { operações militares (...) Considerando } \\
\text { que a capitulação dos mesmos é de se } \\
\text { fazer no art. } 192 \text {, por não se verificar a } \\
\text { hipótese do art. } 312 \text {, quanto ao estupro } \\
\text { praticado em Nerina Giberni, atribuído a }\end{array}$ & $\begin{array}{l}\text { APELAÇÃO } \mathrm{N}^{\circ} \text { 50- } \\
\text { ALESSANDRIA- } \\
\text { ITÁLIA } \\
\text { “(...) resolvem os } \\
\text { Juízes do Conselho } \\
\text { Supremo da Justiça } \\
\text { Militar }\end{array}$ \\
\hline
\end{tabular}




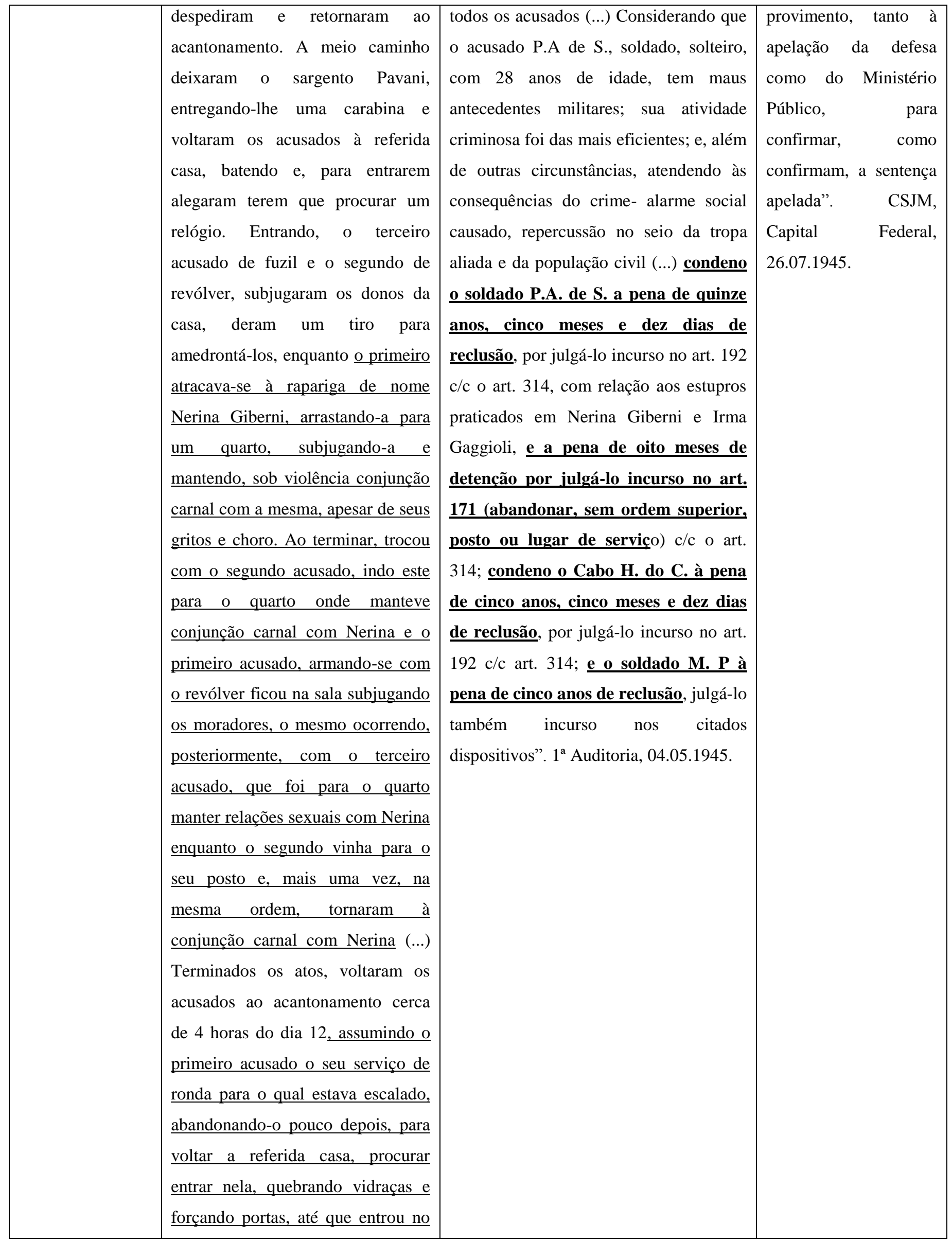




\begin{tabular}{|c|c|c|c|}
\hline & $\begin{array}{l}\text { estábulo da mesma arrombando a } \\
\text { sua porta e aí, encontrando a } \\
\text { italiana Irma Gaggioli, forçou-a, } \\
\text { armado de revólver, dando um tiro } \\
\text { para intimidá-la a ir para o quarto } \\
\text { com ele afim de manterem } \\
\text { conjunção carnal e satisfeito o seu } \\
\text { instinto, retirou-se cerca das } 7 \\
\text { horas, voltando ao seu posto." }\end{array}$ & & \\
\hline $\begin{array}{l}\text { M.G. e J.A. de Q., } \\
\text { Soldados }\end{array}$ & $\begin{array}{l}\text { "Narrou a vítima que ia pela estrada } \\
\text { quando notou que três soldados } \\
\text { vinham ao seu encontro em atitude } \\
\text { suspeita; que, receosa, procurou } \\
\text { fugir por um atalho, no que foi } \\
\text { impedida pelas referidas praças que } \\
\text { passaram a lhe fazer propostas } \\
\text { amorosas; que, esperando ser } \\
\text { respeitada, alegou que era casada, o } \\
\text { que não impediu porém que fosse } \\
\underline{\text { empurrada de modo a cair, sendo }} \\
\text { que, nessa ocasião, lhe vendaram os } \\
\text { olhos, lhe taparam o nariz e a boca, } \\
\underline{\text { e comprimindo-lhe o estômago com }} \\
\underline{\text { o joelho procuraram violenta-la, }} \\
\text { pois notou que lhe rasgavam as } \\
\underline{\text { calças; que, reagindo, entrou em }} \\
\underline{\text { luta com os seus subjugadores, ao }} \\
\underline{\text { mesmo tempo que gritava pedindo }} \\
\underline{\text { socorro, até que foi abandonada e }} \\
\text { regressou à sua casa, sem que } \\
\text { sofresse maior dano". }\end{array}$ & 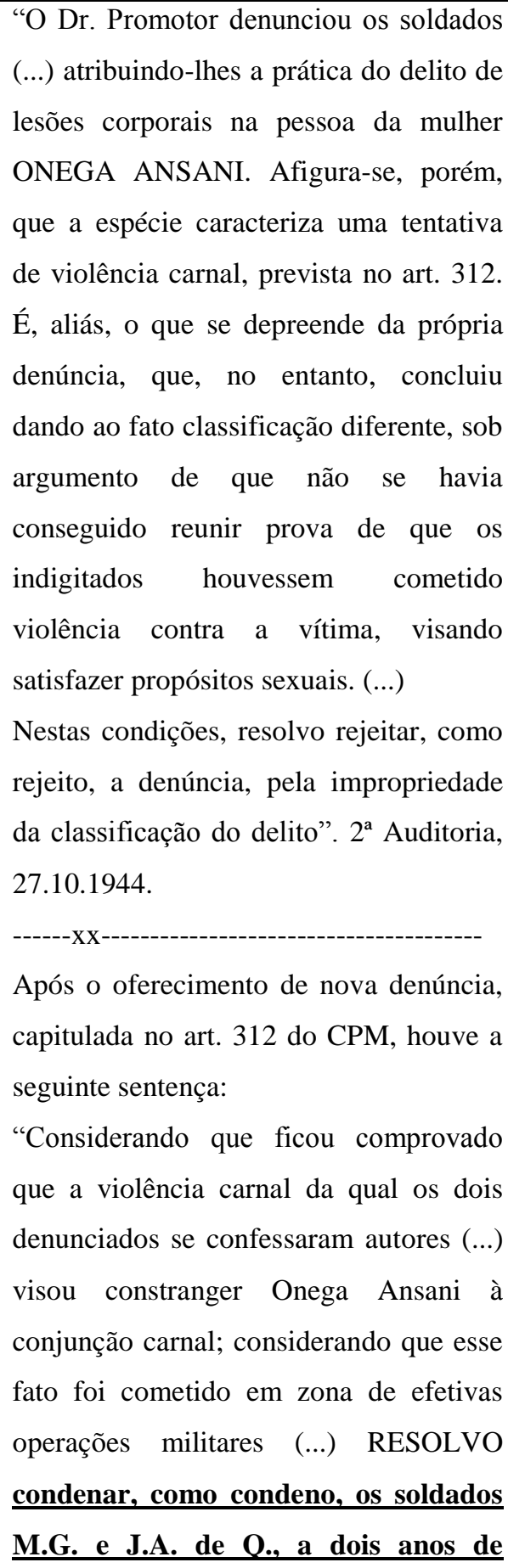 & $\begin{array}{l}\text { APELAÇÃO No 9- } \\
\text { PISTÓIA- ITÁLIA } \\
\text { “(..) acorda o } \\
\text { Conselho Supremo da } \\
\text { Justiça Militar, por } \\
\text { unanimidade de votos } \\
\text { de seus juízes, em } \\
\text { negar provimento à } \\
\text { apelação para } \\
\text { confirmar, como } \\
\text { confirmam, pelos seus } \\
\text { fundamentos, } \\
\text { sentença apelada”. } \\
\text { CSJM, Nápoles, } \\
\text { 16.12.1944. }\end{array}$ \\
\hline
\end{tabular}




\begin{tabular}{|c|c|c|c|}
\hline & & 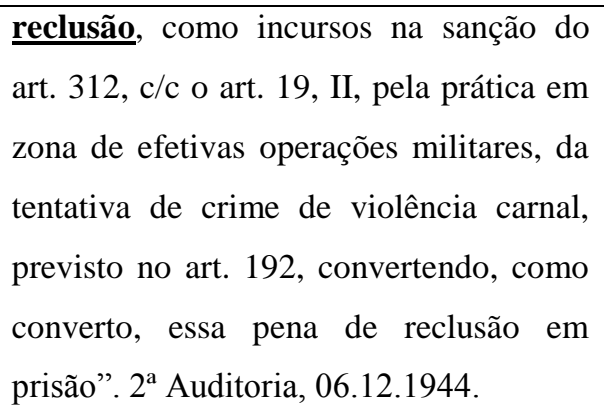 & \\
\hline $\begin{array}{l}\text { Soldados A.F., } \\
\text { M.H. da S. e J.T. } \\
\text { C, do IV Grupo } \\
\text { de Artilharia }\end{array}$ & $\begin{array}{l}\text { "Na madrugada de } 27 \text { de fevereiro } \\
\text { de } 1945 \text {, em Vimignamo, Itália, } \\
\text { zona de efetivas operações } \\
\text { militares, ou em presença do } \\
\text { inimigo, mediante violência, } \\
\text { forçaram ELMI TOSCA, italiana } \\
\text { com } 17 \text { anos de idade, a ter com } \\
\text { eles conjunção carnal, deflorando-a } \\
\text { e produzindo as demais lesões } \\
\text { descritas no auto de corpo de delito } \\
\text { a fls. } 28 \text { - e de ocasionaram ainda as } \\
\text { lesões corporais, constantes do } \\
\text { laudo de fls. 30, na pessoa de ELMI } \\
\text { GIOVANI, pai daquela moça, } \\
\text { quando ele e sua esposa, SAPORI } \\
\text { IDA, procuravam impedir fosse } \\
\text { violentada aquela sua filha". }\end{array}$ & 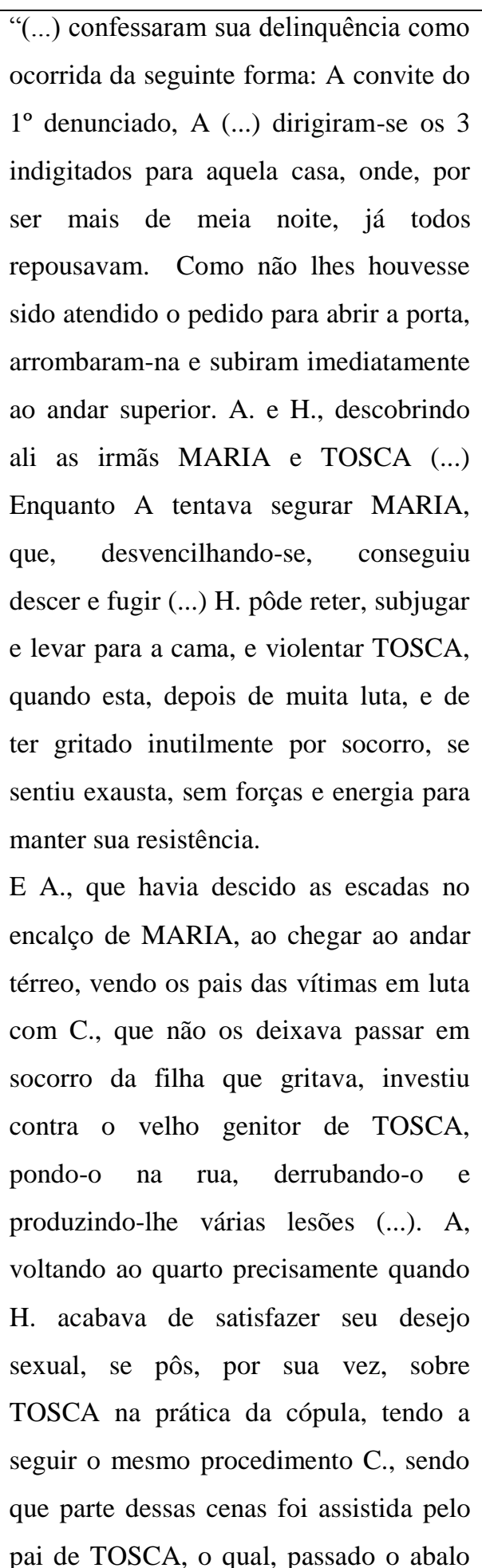 & 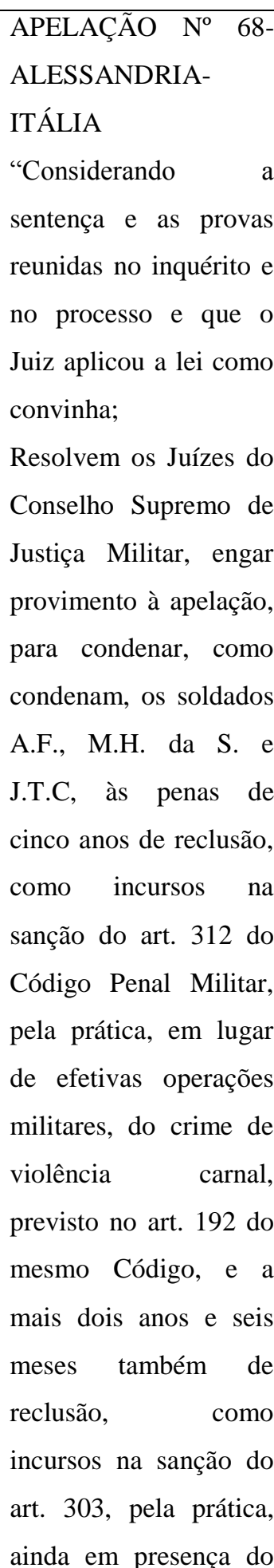 \\
\hline
\end{tabular}




\begin{tabular}{|c|c|c|c|}
\hline & & 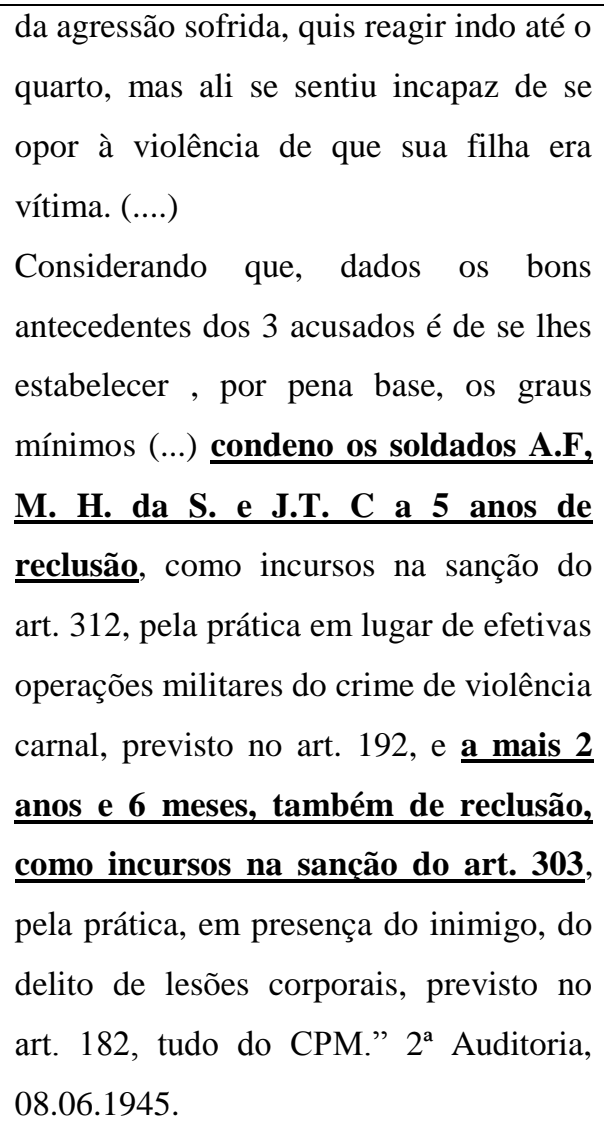 & $\begin{array}{l}\text { inimigo, de lesões } \\
\text { corporais, } \\
\text { previsto no art. 182, } \\
\text { tudo do Código Penal } \\
\text { Militar, ou seja a sete } \\
\text { anos e seis meses de } \\
\text { reclusão, na forma da } \\
\text { sentença apelada". } \\
\text { CJSM, Capital Federal, } \\
\text { 02.08.1945. }\end{array}$ \\
\hline $\begin{array}{l}\text { Soldados do } \\
\text { Depósito de } \\
\text { Pessoal da FEB, } \\
\text { J.M, S. da C. M., } \\
\text { A.M.C e S.A }\end{array}$ & $\begin{array}{l}\text { "No dia } 7 \text { de janeiro de } 1945 \text {, cerca } \\
\text { da } 17 \text { horas, na estrada de Staffoli a } \\
\text { Orantano, Itália- mediante } \\
\text { violência, forcaram a italiana } \\
\text { DINI ANNITA CAMPORINI a } \\
\text { ter com eles conjunção carnal. As } \\
\text { oitivas comprovaram que a D. } \\
\text { ANNITA e seu esposo, Sr. } \\
\text { MAULIO, se encaminhavam para a } \\
\text { Igreja, quando foram cercados e } \\
\text { agredidos por um grupo de } \\
\text { militares. O Sr. MAULIO, } \\
\text { conseguindo desvencilhar-se, saiu } \\
\text { correndo em busca de socorro, } \\
\text { enquanto que D. ANNITA, sendo } \\
\text { agarrada por } 4 \text { praças, foi } \\
\text { derrubada, acontecendo mais que } \\
\text { um dos soldados, armado de faca, } \\
\underline{\text { lhe passou a fazer ameaças ao }} \\
\text { mesmo tempo que lhe rasgava as } \\
\text { calças, não tendo, no entanto, }\end{array}$ & $\begin{array}{l}\text { "Considerando que, pelas declarações da } \\
\text { própria vítima, não se chegou a } \\
\text { consumar o crime de conjunção carnal, } \\
\text { pois pode ela oferecer resistência até que } \\
\text { a ação dos indigitados fosse interrompida } \\
\text { pela intervenção dos dois carabineiros, } \\
\text { sem que aqueles tivessem podido efetuar } \\
\text { a cópula, ficando assim caracterizada na } \\
\text { espécie unicamente uma tentativa (...) } \\
\text { considerando que, pelas narrativas dos } 4 \\
\text { acusados, aliadas às informações das } 2 \\
\text { testemunhas, chega-se à convicção de } \\
\text { que apenas os dois primeiros } \\
\text { denunciados, M. e S., foram os autores } \\
\text { dessa tentativa (...). } \\
\text { RESOLVO condenar os soldados J.M. } \\
\text { e S. da C.M. a } 2 \text { anos, } 2 \text { meses e } 20 \text { dias } \\
\text { de reclusão, como incursos na sanção do } \\
\text { art. } 192 \text { c/c o art. } 19 \text {, II, } 20 \text { e } 314 \text {, tudo } \\
\text { do CPM, pela prática da tentativa do } \\
\text { crime de violência carnal,- e resolvo }\end{array}$ & $\begin{array}{l}\text { APELAÇÃO } \mathrm{N}^{\circ} \text { 75- } \\
\text { FRANCOLISE- } \\
\text { ITÁLIA } \\
\text { “Acordam os Juízes do } \\
\text { Conselho Supremo de } \\
\text { Justiça Militar- em } \\
\text { negar provimento às } \\
\text { apelações, para } \\
\text { confirmar, como } \\
\text { confirmam, por seus } \\
\text { fundamentos, apelada”. } \\
\text { sentença } \\
\text { CSJM, 17.08.1945. }\end{array}$ \\
\hline
\end{tabular}




\begin{tabular}{|c|c|c|c|}
\hline & $\begin{array}{l}\text { chegado a realizar a cópula os que } \\
\text { sobre ela se deitaram, pois graças } \\
\text { aos movimentos que fazia para } \\
\text { fugir ao coito, pode ela evitar que o } \\
\text { contato sexual fosse além de suas } \\
\text { coxas até que seu marido voltasse } \\
\text { com o socorro de } 2 \text { carabineiros, os } \\
\text { quais, com um tiro, puseram os } \\
\text { militares em fuga." }\end{array}$ & $\begin{array}{l}\text { absolver, como absolvo, os soldados } \\
\text { A.M.C. e S.A (....)". 2 } 2^{\text {a }} \text { Auditoria, } \\
\text { 02.07.1945. }\end{array}$ & \\
\hline $\begin{array}{l}\text { Soldado do } 6^{\circ} \\
\text { R.I., B. de P. C. S. }\end{array}$ & $\begin{array}{l}\text { "No dia } 6 \text { de abril de } 1945, \\
\text { achando-se baixado ao 16th } \\
\text { Evacution Hospital, em Pistóia, } \\
\text { Itália, e tendo conseguido levar para } \\
\text { uma das dependências desabitadas } \\
\text { do 'Forte Santa Bárbara', anexo } \\
\text { àquele Hospital, o menor CARLO } \\
\underline{\text { PUCITTA, com dez anos de idade, }} \\
\underline{\text {-havê-lo forçado a se prestar como }} \\
\underline{\text { agente passivo na prática de coito }} \\
\underline{\text { anal, produzindo-lhe as lesões }} \\
\underline{\text { descritas no auto de corpo de delito }} \\
\text { de fls. 11." }\end{array}$ & 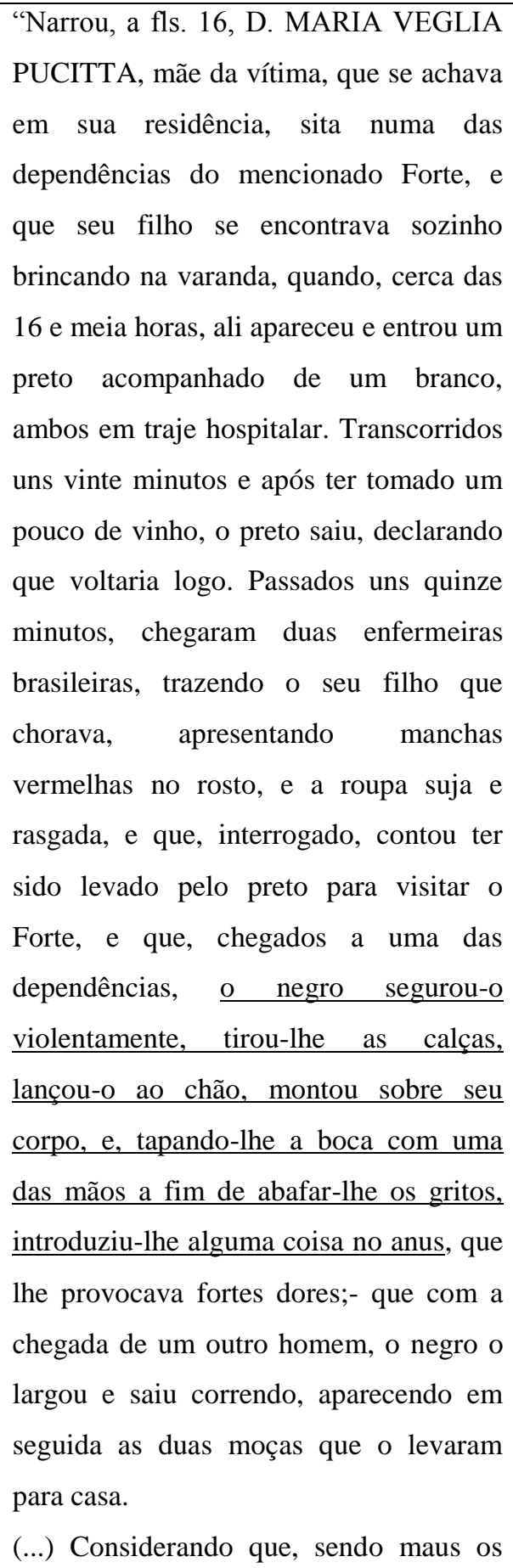 & $\begin{array}{l}\text { APELAÇÃO } \mathrm{N}^{\circ} \\
\text { FRANCOLISE- } \\
\text { ITÁLIA } \\
\text { "Considerando que o } \\
\text { crime está provado o } \\
\text { que evidencia os maus } \\
\text { instintos do ré; } \\
\text { resolvem os juízes do } \\
\text { Conselho Supremo de } \\
\text { Justiça Militar negar } \\
\text { provimento à apelação } \\
\text { e condenar, como } \\
\text { condenam, o soldado } \\
\text { B. de P. C. S. a nove } \\
\text { anos e quatro meses de } \\
\text { reclusão, como incurso } \\
\text { no grau máximo do art. } \\
193 \text { do Código Penal } \\
\text { Militar, tudo na forma } \\
\text { da sentença apelada". } \\
\text { CSJM, Capital Federal, } \\
\text { 13.08.1945. }\end{array}$ \\
\hline
\end{tabular}




\begin{tabular}{|c|c|c|c|}
\hline & & $\begin{array}{l}\text { antecedentes do denunciado, figurando } \\
\text { entre suas punições, três por embriaguez } \\
\text { (...) considerando (...) ter o crime sido } \\
\text { cometido em estado de embriaguez, e em } \\
\text { país estrangeiro (...) } \\
\text { RESOLVO condenar, como condeno, } \\
\text { o soldado B. de P.C.S. a } 9 \text { anos e } 4 \\
\text { meses de reclusão, como incurso na } \\
\text { sanção do art. } 193 \text { do CPM. } 2^{\text {a Auditoria, }} \\
16.07 .1993 \text {. }\end{array}$ & \\
\hline $\begin{array}{l}\text { Soldados do } 11^{\circ} \\
\text { R.I., L.A e P.C. }\end{array}$ & $\begin{array}{l}\text { No dia } 23 \text { de janeiro de } 1945 \text {, cerca } \\
\text { das } 16 \text { horas e } 30 \text { minutos, em } \\
\text { Lizzano, Belvedere, Itália, os dois } \\
\text { acusados, armados respectivamente } \\
\text { de carabina e metralhadora, } \\
\text { entraram na residência da família } \\
\text { Fernando Mouti (...) prenderam } \\
\text { numa sala o dono da casa e os } 4 \\
\text { amigos que ali se achavam em } \\
\text { visita, para em seguida levar, como } \\
\text { levaram, D. Adele Allegrezza, } \\
\underline{\text { esposa de Monti e a sua amiga D. }} \\
\underline{\text { Pia Carrara, para quartos separados, }} \\
\underline{\text { no andar superior, e ali constranger, }} \\
\underline{\text { como constrangeram, }} \text { essas } \\
\underline{\text { senhoras, mediante ameaça e }} \\
\underline{\text { violências, a terem com eles }} \\
\underline{\text { conjunção carnal". }}\end{array}$ & $\begin{array}{l}\text { "Considerando que a espécie se revestiu } \\
\text { das agravantes do art. 59, II, letra 'l' e } \\
\text { 'n', por ter sido o crime praticado com } \\
\text { emprego de arma de serviço, procurada } \\
\text { para esse fim, e em país estrangeiro, e } \\
\text { dada a ausência de atenuantes. } \\
\text { RESOLVO condenar, como condeno, } \\
\text { os soldados L.A. e P.C a } 5 \text { anos e 6 } \\
\text { meses de reclusão, como incursos na } \\
\text { sanção do art. } 312 \text {, pela prática, em zona } \\
\text { de efetivas operações militares, do crime } \\
\text { de violência carnal, previsto no art. 192, } \\
\text { tudo do CPM. } 2^{a} \text { Auditoria, } 17.07 .1945 \text {. }\end{array}$ & $\begin{array}{l}\text { "Vistos e relatados } \\
\text { estes autos, deles se } \\
\text { verifica que } \\
\text { advogado de ofício (...) } \\
\text { apelou da sentença na } \\
\text { parte relativa ao } \\
\text { soldado } \\
\text { condenado a cinco anos } \\
\text { e seis meses de } \\
\text { reclusão (...) deixando } \\
\text { de fazê-lo na parte } \\
\text { referente ao soldado } \\
\text { L.A, } \\
\text { condenado pelo mesmo } \\
\text { delito, porque foi ele } \\
\text { julgado à revelia e se } \\
\text { encontra foragido (...). } \\
\text { Considerando que é } \\
\text { obrigatória a apelação } \\
\text { das sentenças, e que o } \\
\text { advogado de ofício não } \\
\text { apelou da condenação } \\
\text { de réu revel, por uma } \\
\text { errônea interpretação } \\
\text { da Lei; } \\
\text { Acordam os Juízes do } \\
\text { Conselho Supremo de } \\
\text { em diligencia para que, }\end{array}$ \\
\hline
\end{tabular}




\begin{tabular}{|l|l|l|l|}
\hline & & & $\begin{array}{l}\text { intimado o advogado } \\
\text { de ofício da sentença } \\
\text { na parte relativa ao réu } \\
\text { revel, interponha o } \\
\text { recurso legal". CSJM, } \\
\text { Capital Federal, } \\
20.08 .1945 .\end{array}$ \\
\hline
\end{tabular}

A partir dos trechos acima expostos, contido nos autos e copilado no livro "A Justiça Militar na Campanha da Itália" ${ }^{305}$ - citado nas referências bibliográficas, é possível vislumbrar que o modus operandi praticado pelos soldados era bastante semelhante: grupos de dois ou mais pracinhas, iam a uma casa armados, acuavam os presentes, se trancavam no quarto com a vítima e, enquanto um satisfazia sua lascívia, os outros ficavam de guarda, revezando até todos se satisfazerem.

Quase todos os atos eram parecidos com o supra citado, exceto o caso de um soldado que estava baixado no 16th Evacuation Hospital, em Pistoia, Itália, que usou da força para violentar e estuprar um garoto italiano de 10 anos. Conforme relatado, o soldado saiu do hospital com outro amigo em trajes de enfermo e foi à casa da vítima; persuadiu e levou a criança nas dependências de um de um Forte desabitado e a forçou a se prestar como coito passivo na pratica de sexo anal, parando no ato de ser flagrado por enfermeiras brasileiras. Resultado: foi denunciado e recebeu pena de 9 anos e 4 meses de prisão.

Se por um lado, essas histórias mostram a barbárie de soldados despreparados e desorientados; por outro mostra a falta de critério dos julgadores da Justiça Militar Expedicionária Brasileira, que se deixavam influenciar por sentimentos outros, distintos da imparcialidade característica dos órgãos judicantes. Isso podia ser visto a partir da capacidade das sentenças de FEB de prescreverem penas absolutamente distintas, quanto a gravidade, em referência a crimes semelhantes, desenvolvidos a partir do mesmo modus operandi e com as mesmas violações perpetradas: sentenças que flutuavam desde 02 anos a 05 anos de reclusão, passando pelos 15 anos de condenação até chegar à retratada condenação à pena de morte.

Nada obstante, a despeito do alarmante vício de julgamento apontado, a maioria das sentenças proferidas pela Justiça Militar não foi cumprida, pois em 3 de dezembro de 1945, através do Decreto no 20.082, o Executivo Federal resolveu indultar a 
todos os oficias e praças que, como integrantes da FEB, houvessem cometido crimes ou infrações perante os inimigos. Os que ficaram de foram desse indulto (condenados por homicídio doloso), tiveram sua pena comutada.

A respeito do indulto presidencial, observa Joaquim Xavier da Silveira que a disciplina tão duramente observada, fosse pela tropa, fosse pelas duras sentenças proferidas pela Justiça da FEB, na tentativa de resguardar a manutenção da hierarquia e disciplina tão caras àquela Força Expedicionária, foi preterida por esse ato de graça que, sem respaldo na moral ou na razão, acabou igualando todos aqueles que no combate cumpriram com seu dever e observaram a disciplina, aos que cometeram infrações graves ou crimes ${ }^{306}$.

Houve um sentimento de injustiça a esse respeito. A propósito, o General Francisco Paula Cidade, por ocasião da sessão de encerramento do Conselho Supremo da Justiça Militar, em 24.01.1946, pronunciou palavras que merecerem ser transcritas e explicam exatamente o sentimento que permeou a Justiça Militar da FEB, ante às aludidas decisões tomadas pelo Executivo Federal:

"Ao encerrarmos nossos trabalhos com a dissolucão do CSJM, cuja existência se tornou desnecessária com o indulto concedido aos condenados, no cumprimento de um dever penoso, quero entregar à história, para a qual estou depondo, 0 julgamento de nossos atos, na parte que me toca. Ao julgador cauteloso, que alguns anos mais tarde viera folhear esses autos, não escapará que o coração predominou sempre que isso se podia dar sem que a lei fosse ferida. 0 nosso tribunal condenou á morte apenas dois delinquentes, embora houvesse muitas oportunidades para aplicar a pena máxima. Ora, isso é um recorde que espantará os criminalistas de outros Exércitos em luta. Ao deixarmos a Itália, sabíamos que havia, só numa prisão, dezesseis norteamericanos que aguardavam a hora de serem executados, muitos deles por crimes que a nossa legislação pune levemente. São as contingências da guerra e não as más entranhas dos juízes que ditam as sentencas mais severas, o que parece que no Brasil não se compreende bem. Aliás, Sr. Presidente, a maneira por que tenho sido interpelado por muitos de nossos camaradas, que acreditavam que o indulto tivesse partido do Conselho, tem me capacitado que a nossa ação firma agradou à imensa maioria do Exército.

Não se veja, Drs. Juízes, nas minhas palavras o desejo de manter na cadeia todos os que foram por nós condenados, pois em muitos casos eu desejei recomendar ao governo uma medida de clemência, o que não fiz só porque a lei não m'o permitia. Acredito que tenho assim respondido convenientemente aos que, sob o império de outros interesses, tenham visto no Conselho um órgão inútil e tenebroso. Aí ficam nossos acórdãos que, contemplados pelas explanações que eu e outros faremos oportunamente pela imprensa, permitirão aos historiadores do futuro ver claro entre as cortinas de fumaça, que nos envolvem neste momento. Compreender-se-á então como defendemos aos olhos do Mundo o nome do Brasil e a honra de suas forças armadas".

\footnotetext{
305 Albuquerque. B.C.L. L. A Justiça Militar na Campanha da Itália. Fortaleza: Imprensa Oficial, 1958.

${ }^{306}$ SILVEIRA, Joaquim Xavier da. A FEB por um Soldado. Rio de Janeiro. Biblioteca do Exército. 2001. p. 111.
} 
É bem verdade que, se por um lado os juízes da FEB eventualmente agiram com mais benevolência do que seus companheiros de outras das Forças Aliadas, foi possível visualizar que esses mesmos juízes foram capazes de formar convicções e condenarem de forma distinta casos semelhantes, não tendo se podido comprovar se a isenção fora maculada partir de influências externas ao seio da tropa. O que importava, em última análise, era julgar os delitos de acordo com as leis penais existentes e isto o fizeram com aparente segurança.

Em razão disso, ao fim e ao cabo, foi dispensada à Justiça Militar da FEB referência elogiosa ${ }^{307}$ pelo então comandante da Força Expedicionária, a qual se passa a transcrever:

\begin{abstract}
"Os homens não poderiam viver em sociedade, nem a sociedade beneficiar-se da ordem necessária ao seu progresso, se não existissem regras jurídicas capazes de cercear os maus e amparar os bons, fixando claramente os direitos e deveres que a todos cabem no seio das coletividades humanas.

Mesmo no quadro tormentoso da guerra, que é o recurso extremo e violento de que lançam mão os homens para solução dos conflitos internacionais, não se travariam combates e batalhes e, sim, choques e encontros desordenados entre facções ou hostes desenfreadas, se os exércitos em luta não se movessem dentro dos limites demarcados pelas regras e princípios regulamentares e os soldados individualmente não se submetessem à autoridade soberana da Lei. Isto é tanto mais verdade quanto mais amplo o quadro em que vivemos e agimos.

Sem a lei, que é a disciplina e o cimento das aglomerações humanas, e sem a justiça, que é a confiança em que repousam os ideais, e a ânsia de viver da humanidade, a anarquia seria o princípio, e a dissolução e o caos, o destino de todas as coletividades o fim melancólico da própria espécie humana.

Sem esses elementos, que são fatores essenciais da ordem e do progresso, o homem deixaria de ser o artificie de uma civilização, para tornar-se apenas um vulgar espécime da criação divina.

Essas considerações gerais de verdadeira exaltação à majestade da lei vêm a propósito do trabalho realizado neste Teatro de Operações, no âmbito da Força Expedicionária Brasileira, pela Justiça Militar.

A Justiça Militar da FEB, em todos os degraus da sua hierarquia e atividade, do juízo da $1^{a}$ Entrância ao Conselho Supremo, tem estado à altura do momento e da sua nobre missão.

Vigilante e inflexível, imparcial e serena, meticulosa na elaboração processual, rígida nos seus julgamentos e exata e exemplar nas suas sentenças, a nossa Justiça Militar vem concorrendo eficientemente para que não se partam os elos da disciplina e não se quebre a coesão moral da tropa que o Brasil mandou ao Continente Europeu, como legítima expressão do seu poder militar e como genuína representante dos princípios secularmente esposados e defendidos pela sua nobre e invariável política internacional.

Enquanto os nossos bravos soldados conquistam belos e imorredouros triunfos para as armas nacionais, a Justiça Militar da FEB vela permanentemente para que não se empane o brilho da nossa atuação nestes campos de batalha e nem de leve esmaeça o colorido do prestígio e do conceito que já conquistamos, mercê do valor dos nossos homens e da compreensão nítida das nossas responsabilidades.
\end{abstract}

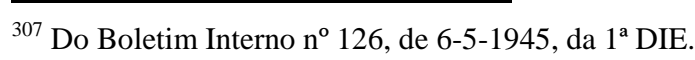


A Justiça Militar da FEB, incansável sentinela da lei, rendemos hoje o preito da nossa admiração, pelo valioso e patriótico trabalho que vem realizando, na defesa das nossas tradições de culturas e cavalheirismo e pelo maior e mais puro prestígio do Exército do Brasil.”

Assim, vislumbra-se que na Itália, cenário de dificuldades em que os esforçados pracinhas se encontravam para combater as tropas nazifascistas, foi reconhecido o valor da Justiça Militar Expedicionária, que se prestou à preservação da hierarquia, disciplina e coesão moral da tropa, com suas "sentenças exemplares" na função de sentinela da lei, merecendo, em função disso, elogio por parte das autoridades militares. 


\section{CONCLUSÕES}

"A Guerra é uma tragédia para quem ganha e para quem perde". (Geraldo Campos Taitson, Veterano da FEB)

As guerras mundiais do século XX mobilizaram milhões de combatentes, de diversos cantos do globo, dentre os quais jovens civis despontavam como a maioria dos soldados enviados para lutar no conflito. Muitos tiveram que deixar seus empregos, estudos e famílias, a fim de combater outros milhões de cidadãos que, porventura, se viam na mesma situação.

A Segunda Guerra Mundial, em especial, fruto da tentativa de imposição de ideologias totalitárias, trouxe grande sofrimento ao mundo, gerado pela maciça perda de combatentes e civis; pela odiosa perseguição étnica e pela miséria que se abateu sobre os povos, devido à escassez de matérias-primas e meios de produção.

O Brasil fez parte do conflito, enviando a Força Expedicionária Brasileira para combater no Teatro de Guerra da Itália. Pracinhas --convocados desde cidades atendidas pela malha ferroviária, até regiões rurais, de difícil acesso-- foram selecionados sem critérios, passando a compor um efetivo de origem eminentemente civil. Deixaram família, amigos e a terra natal, para enfrentarem os obstáculos que se apresentavam naquele cenário estranho à tropa, desconhecido pela grande maioria.

Contudo, as campanhas de Monte Castelo, Castelnuovo, Montese, Vale do Pó e tantas outras, possíveis com a superação dos combatentes brasileiros que fizeram parte da guerra, também contaram com homens tão determinados quanto os oficiais e praças da FEB. Eram juízes, promotores, advogados e servidores que, envergando os uniformes da FEB, com o distintivo da balança com uma espada como fiel, atuaram com a missão de processar e julgar crimes, na tentativa de velar pela hierarquia, disciplina e coesão moral da tropa em combate.

É bem de se ver que o segmento militar, em qualquer país do mundo, é regido por um vasto e profuso campo de normas e princípios jurídicos. Este setor sempre foi valorizado pelas sociedades humanas, ocupando importante parcela do organograma estatal, exatamente por conferir a estabilidade de que cada Estado necessita para realizar suas diferentes tarefas ${ }^{308}$.

\footnotetext{
308 Os serviços militares apresentam tríplice aspecto: (a) defesa da pátria; (b) defesa das instituições que garantem o funcionamento e a vida democrática do Estado: Parlamento, Governo, regiões, administrações locais, etc.; (c) salvaguarda da ordem e da estabilidade interna. Fonte: Norberto Bobbio; Dicionário de Política; p. 505 e 506.
} 
De inferir-se, por sua vez, que a funcionalidade de tão intrincada estrutura militar requer gestão disciplinadora, que não pode se compaginar com a adoção de princípios débeis ou vacilantes. Quando um militar deixa de cumprir a ordem legal de seu superior, o entendimento da caserna ruma no sentido de que tal desobediência não atinge, apenas, a dignidade funcional de quem lhe comanda, mas faz estremecer todo o edifício castrense, permeado, visceralmente, pelos princípios da disciplina e hierarquia, dentre outros que gravitam na administração militar.

Imagine-se os inevitáveis prejuízos para a defesa e imagem do país, que poderiam acarretar afrouxamento da autoridade e da disciplina militar em pleno cenário de beligerância. Tal rigor se justifica, ademais, em razão da necessidade de se resguardar irrestrita harmonia e conformidade aos pilares da ordem e do respeito que calam a estrutura funcional castrense. Uma vez ausentes, não subsistiriam forças armadas, mas meros ajuntamentos de seres humanos, dispersos, sem preocupação maior de unidade.

É a partir de tal perspectiva que se deve observar o ordenamento jurídico militar da guerra, em que a severidade das punições e o tolhimento de garantias constitucionais (como a ausência da figura do habeas corpus, a permissão do superior usar de violência com o inferior hierárquico a fim de compeli-lo ao cumprimento de ordem, a possibilidade do soldado ser julgado e sentenciado abrindo mão de uma defesa técnica, além de sequer ser exigida sua presença nas sessões de instrução e julgamento, etc) apesar de saltar aos olhos dos cidadãos de hoje, guardavam harmonia com a gravidade do momento vivenciado. Não se pode considerá-lo um direito penal de exceção, mas considerá-lo como um ordenamento rígido, que visava garantir o equilíbrio e o senso de responsabilidade no cumprimento das missões, além da preservação da hierarquia, disciplina e coesão moral da FEB, em sua primeira e única incursão nos campos de um conflito bélico de proporção mundial.

Nesses auspícios, a Justiça Expedicionária foi responsável por sentenciar um total de 406 anos, 11 meses e 24 dias $^{309}$. Houve, apenas, duas condenações à pena capital, provenientes de expedicionários lotados em órgãos da retaguarda, acusados de estuprarem uma jovem, e assisarem um civil italiano a fim de assegurarem a execução da violência carnal, tudo com as agravantes de agirem embriagados, com emprego de armas de serviço procuradas para aquele fim; em zona de efetivas operações militares em país estrangeiro.

${ }^{309}$ ALBUQUERQUE, Bento C. L. A Justiça Militar na Campanha da Itália. Fortaleza: Imprensa Oficial, 1958. p. 620. 
É bem verdade que restou noticiado, pelo autor, a falta de critério dos julgadores da Justiça Militar Expedicionária Brasileira, que se deixavam influenciar por sentimentos outros, distintos da imparcialidade característica dos órgãos judicantes. Isso pôde ser verificado a partir de sentenças que prescreveram penas absolutamente distintas, em relação a crimes semelhantes, desenvolvidos com o mesmo modus operandi: condenações que flutuavam desde 02 anos a 05 anos de reclusão, passando pelos 15 anos de prisão, culminando com a retratada pena de morte.

Ademais, em levantamento realizado na Seção de Arquivo do STM, onde estão armazenados os processos originados à época da Campanha da Itália, constatou-se que os crimes mais comuns cometidos durante a campanha da Itália foram os de deserção e os de lesão corporal nos órgãos de retaguarda (os crimes sexuais tiveram baixa incidência, comparativamente, razões explicitadas no tópico anterior), o que pode, em parte, ser explicado pela pesquisa realizada, em $1962^{310}$, pelo terceiro ano da Escola de Comando e Estado-Maior do Exército, intitulada " $O$ comportamento do combatente brasileiro na Itália"311.

Com vistas a tirar ensinamentos de engenharia humana da experiência de guerra brasileira, foram obtidas as conclusões de que o combatente brasileiro não se adaptou, ou mesmos reagiu a normas disciplinares rígidas, aduzindo que os pracinhas -"se submetiam apenas à liderança afetiva dos chefes que o comandavam pelo exemplo e não aos ausentes espiritualmente, e insensíveis às esperanças, aspirações, imaginação e sentimentos de seus homens"--.

Com efeito, nos órgãos de retaguarda da $1^{\text {a }}$ D.I.E era notada uma alocação maior de oficiais do que os regimentos engajados em combate, que relembravam ao soldado a vida militar no Brasil ("Exército Caxias"). Assim, essa pesquisa demonstra, à luz do mandonismo pregado por aqueles oficiais --elemento disciplinador baseado no medo e no receio do castigo--, o porquê da maior incidência de delitos nos órgãos que

\footnotetext{
${ }^{310}$ Destaque-se, aqui, o atraso com que foi produzido relatório referente à FEB. Ainda em guerra, o Departamento de Guerra americano enviou, em 06 de abril de 1945, correspondência ao comandante das forças do Exército dos EUA no Atlântico Sul, sob as quais as tropas brasileiras se viam subordinadas, alertando para a inconveniência da desmobilização imediata da Força Expedicionária Brasileira ("FEB") quando do seu retorno ao Brasil.

Observavam no comentado documento que -"uma vez que é a única unidade do Exército brasileiro inteiramente treinada pelos EUA, considera-se que tem grande valor como um núcleo para o treinamento de outros elementos do Exército brasileiro e como uma contribuição potencialmente valiosa do Brasil à defesa hemisférica ."

Em que pese a preocupação exposta pelos Estados Unidos e, mesmo compartilhando com a máquina de guerra daquele país, os planejamentos e a execução de todas as etapas de combate, foram pouquíssimas - e por que não dizer irrelevantes- asa ações de pesquisa e estudo referentes aos "pracinhas" que vieram a ser adotadas pelo Governo brasileiro, tendo as autoridades militares brasileiras optado por desmobilizar sumariamente a FEB.

${ }^{311} \mathrm{http}: / /$ www.ahimtb.org.br/montecastelo.htm (acesso em 21.09.2016).
} 
operavam $^{312}$ mais recuados, sobretudo na unidade de Depósito de Pessoal da FEB, onde estavam os expedicionários mais insatisfeitos (não se olvidar das "deserções às avessas", também contadas como deserção, nas estatísticas).

Nesse cenário, a Justiça Militar registrou um total de 137 condenações, sendo apenas duas condenações à pena capital --comutadas e reduzidas em duas oportunidades, finalizando com o cumprimento de apenas seis anos de pena -, o que representa $0,54 \%$ de todo o contingente - menos de $1 \%$ da tropa.

Nada obstante, em dezembro de 1945, o Governo, por meio do decreto 20.082 de 1945, concedeu indulto-- ato de perdão do Chefe do Executivo, em virtude do qual ficam isentos da pena, e os efeitos por ela atribuídos, determinados indivíduos-- a todos os oficiais, praças e civis que, fizeram parte integrante da FEB, já condenados ou não (julgamento em trâmite), cujos crimes não fossem de natureza extremamente grave, como homicídio ou deserção para o inimigo.

Uma vez desvirtuada a aplicação real das normas contidas no Código Penal Militar, pois aos criminosos julgados pela Justiça Expedicionária fora concedido indulto, a existência daquela Justiça especializada tornou-se desnecessária. É bem verdade que ainda subsistem dúvidas acerca das verdadeiras motivações que levaram o Executivo Federal a adotar tal medida, conquanto essa atitude política divergia das razões que imperavam quando do envio, ao Teatro de Operações da Itália, da Justiça Militar; que, em última instância, poderia simplesmente ter permanecido no Brasil, em condições adequadas de trabalho.

Contudo, a Justiça Militar expedicionária, criada como indispensável para manter a operacionalidade da FEB, não apenas julgou, mas também foi julgada. Quando do encerramento de seus trabalhos, o General Cidade $^{313}$, reconhecendo que sua existência tornara-se desnecessária em razão do indulto concedido à esmagadora maioria dos condenados, admitiu que nas decisões proferidas naquele órgão -“o coração predominou sempre que isso se podia dar sem que a lei fosse ferida"--, recordando que o tribunal condenou à morte apenas dois criminosos, --“embora houvesse muitas oportunidades para aplicar a pena máxima"--, o que, em sua opinião, -“espantará os criminalistas dos outros Exércitos em luta"--.

Comparando a atuação da Justiça castrense brasileira com a americana, o General recorda que, só em uma prisão, havia 16 soldados americanos que aguardavam a

\footnotetext{
${ }^{312}$ ALBUQUERQUE, p. 622 e 628.

${ }^{313}$ Idem, p. 613 e 614.
} 
execução, sendo que muitos deles haviam cometidos crimes que a legislação brasileira pune muito levemente, para concluir um tanto enigmaticamente -"são as contingências da guerra e não as más estranhas dos juízes que ditam as sentenças mais severas, o que parece que no Brasil não se compreende bem"--- 314.

Por seu turno, Manoel Castelo Branco comentou, a respeito da atuação da Justiça Militar expedicionária, que — “na verdade, os nossos juízes agiram com mais benevolência do que os seus companheiros do Exército norte-americano, sempre mais frios e insensíveis às súplicas dos delinquentes"--. Porém, em seu entender, nem por isso os nossos magistrados seriam merecedores de críticas, já que sempre julgaram -“com isenção e segurança"--.

Embora Castelo Branco reconheça que se os dois condenados à morte fossem militares americanos, -“teriam sido fatalmente fuzilados como tantos outros"--, em seu entendimento, a decisão de protelar a execução de suas penas não decorreu de "interferência deste ou aquele"--, mas simplesmente da -“magnanimidade muito própria dos nossos corações"-- 315 .

Em nota de Comando, datada de 20 de abril de 1945, o comandante da FEB, João Batista Mascarenhas de Morais, definiu em simples palavras, a importância da Justiça na guerra:

\footnotetext{
"Mesmo no quadro tormentoso da guerra, que é o recurso extremo e violento a que lançam mão os homens para a solução dos conflitos internacionais, não se travariam combates e batalhas e sim choques e encontros desordenados entre as facções ou hostes desenfreadas, se os exércitos em luta não se movessem dentro dos limites de marcados pelas regras e princípios regulamentares e os soldados individualmente não se submetessem à autoridade soberana da Lei”.
}

Nesse sentido, o comandante das tropas brasileiras reconheceu o trabalho da Justiça militar e ressaltou que concorreu "eficientemente" para que os elos da disciplina não se partissem e não se quebrasse a coesão moral da tropa que o Brasil havia enviado ao continente europeu, --“como legítima expressão de seu poder militar”--.

É bem verdade, que os julgamentos da Justiça Militar se faziam sentir perante a tropa, sendo motivo de orgulho para os comandantes estarem diante homens que não tivessem sido submetidos àquela justiça especializada, conforme se pode observar do

\footnotetext{
${ }^{314}$ Idem.

${ }^{315}$ CASTEllo BRANCO, Manoel Thomaz. A Força Expedicionária Brasileira; p. 341.
} 
depoimento $^{316}$, em forma de anedota, contado pelo Marechal Waldemar Levy $\operatorname{Cardoso}^{317}$ à edição comemorativa de 60 anos do STM em revista ${ }^{318}$ :

\begin{abstract}
"Outro motivo de orgulho: --"nunca tive um soldado do meu grupo, na FEB, submetido à Justiça Militar. Casos de militares julgados, sabíamos da existência, mas nunca entre os meus comandados"--, revelou o Marechal. Uma das razões é explicada com sinceridade absoluta. Ele conta que, durante o período de formação de seu grupo, recebeu soldados de várias unidades, mas, antes de ir para a Itália, fez uma seleção rigorosa e comunicou ao Ministro da Guerra: --"estou deixando no quartel verdadeiros bandidos. O senhor tome providências para nomear um Oficial que tenha pulso para dirigir essa gente".
\end{abstract}

O Marechal Levy, em sua lucidez de 105 anos de vida, também deixou consignado seu reconhecimento à atuação da Justiça Militar. Se em tempos de guerra -“as decisões são mais rápidas e as punições mais severas"--, tudo é justificado para que -"se mantenha a disciplina na tropa"--. Segundo o Marechal, as punições rigorosas dos culpados serviram de exemplo para os outros, coibindo a ocorrência de outras transgressões (o que poderia explicar o rigor excessivo demonstrado no julgamento de determinados casos, dentre os quais destaca-se as condenações à morte aplicadas).

Com efeito, nenhum país pode se permitir perder uma guerra. Da mesma maneira, forças armadas não se improvisam, pois como nos magistrais versos de Camões, já no século XVI, --“a disciplina militar prestante não se aprende, senhor, na fantasia, sonhando, imaginando. Senão vendo, tratando e pelejando (...)"--.

Só a disciplina mantém a coesão, possibilita a vitória sobre o medo. Só o respeito à hierarquia impede que alguém armado se transforme em uma besta-fera ou em um covarde ao ver companheiros caindo, explosões se sucedendo, gritos, desespero, situações correntes em um cenário de beligerância.

Ainda, impende asseverar que o término da guerra acarretou inevitáveis consequências ao campo político nacional. A participação do Brasil na $2^{\mathrm{a}}$ Guerra, travada contra ditaduras, ao final vencidas, tornou evidente a contradição entre a vida política nacional, pautada pela anormalidade institucional de um regime autocrático, e o regime democrático.

A presença do Brasil naquele conflito, além da contribuição militar propriamente dita e do fornecimento e transporte marítimo das chamadas mercadorias

\footnotetext{
${ }^{316}$ Entrevista realizada em 18 de novembro de 2005 com o Marechal Levy, em sua casa no Rio de Janeiro.

${ }^{317}$ Nascido em 04 de dezembro de 1900, o então Tenente-Coronel Levy comandou cerca de 400 homens do $1^{\circ}$ Grupo de Artilharia Expedicionária no teatro de guerra da Itália e desempenhou, na conquista de Monte Castelo, o papel de Oficial de Ligação entre a Artilharia Divisionária Expedicionária e o Regimento de Infantaria, encarregado do ataque.

${ }^{318}$ STM em Revista, Ano 2, no 2, Julho-Dezembro de 2005, Edição "60 anos da atuação da Justiça Militar na Segunda Guerra".
} 
estratégicas, afinou os sentimentos democráticos e os valores humanísticos do povo brasileiro com os daqueles aliados que se bateram por um mundo fundado em uma ordem jurídica supranacional e no respeito aos direitos humanos.

Com a redemocratização nacional, uma Assembleia Constituinte promulgou uma nova Constituição em 18 de setembro de 1946, conservando a Justiça Militar como órgão integrante do Poder Judiciário, atribuindo-lhe, em seu artigo 108, competência para -“processar e julgar, nos crimes militares definidos em lei, os militares e as pessoas que lhes são assemelhadas"— e admitindo, no parágrafo $\S 1^{\circ}$, que -“o foro especial poderá estender-se aos civis, nos casos expressos em lei, para a repressão de crimes contra a segurança externa do País ou as instituições militares"--.

Também se previu, na Carta Constitucional, a existência da Justiça Militar estadual, organizada com observância dos preceitos gerais da lei federal (disposições do artigo $5^{\circ}$, inciso XV, alínea ' $\mathrm{f}$ ', da Constituição de 46), tendo como órgãos de $1^{\mathrm{a}}$ instância os Conselhos de Justiça e como órgão de $2^{\mathrm{a}}$ instância um Tribunal especial ou o Tribunal de Justiça (artigo 124, inciso XII, da Constituição).

Por sua vez, o Ministério Público Militar foi reconhecido como integrante do Ministério Público Militar, nos termos do artigo 125 da Carta Magna-“a lei organizará o Ministério Público da União, junto à Justiça comum, a Militar, a Eleitoral e a do Trabalho"--.

Por outro lado, a extinção do Estado Novo acarretou, igualmente, a extinção do Tribunal de Segurança Nacional, uma verdadeira- “Justiça de exceção"--, criada para julgar crimes contra a segurança do Estado sob controle da ditadura e seus principais chefes militares, o que se deu com a Lei Constitucional n 14, de 17 de novembro de 1945.

A FEB, a seu turno, de volta ao Brasil, recebeu homenagens e uma recepção de gala no Clube Militar, onde foi inaugurada uma grande placa de bronze e onde o general Mascarenhas de Moraes recebeu o título de Presidente de Honra da entidade.

No dia $1^{\circ}$ de janeiro de 1946, a FEB oficialmente deixou de existir, tendo os pracinhas brasileiros ficado à margem do assistencialismo estatal até a promulgação da Constituição de 88. Com efeito, a parte do Exército que permaneceu no Brasil, envolvida em tarefas de defesa territorial na porção mais ao sul do "Hemisfério Ocidental", continuou atrelada às tradições patriarcais dos tempos em que as forças armadas eram principalmente instrumentos de controle social. Era uma organização militar muito diferente daquela formada e vivenciada por conscritos de todos os níveis sociais que lutara ao lado dos Aliados no front. 
As tendências modernizantes observadas na Itália acabaram produzindo um efeito colateral inesperado: parte do oficialato pressentia que os novos costumes desenvolvidos na guerra poderiam se repetir em detrimento da disciplina e reputação dos oficiais que haviam permanecido no Brasil ${ }^{319}$. Por tal razão, a decisão de Vargas de dissipar a FEB, antes mesmo do retorno à pátria, não foi totalmente desaprovada.

Na solenidade de transladação dos corpos dos pracinhas mortos em combate, o Presidente da República, em sua oração em nome do Governo que representava, declarou que a presença daqueles pracinhas mortos se fazia necessária -“ $O$ Brasil precisava de seus mortos como exemplo para os vivos"-- ${ }^{320}$. Verdades ditas em meio à retórica que pautava o populismo varguista.

Da conclusão dos nossos estudos, uma coisa deve ficar bem clara: longe de diminuir a glória da FEB e suas repercussões na redemocratização do Brasil e da modernização do Exército, mais avulta o acervo de serviços que ela prestou ao Brasil; cumpre ressaltar que, apesar das muitas deficiências, omissões ou erros aqui apontados, a tropa brasileira se conduziu tão bem quanto qualquer outra durante toda a campanha.

Com estas palavras, deixo esta contribuição à História Militar do Brasil na Segunda Guerra Mundial. Foi apresentado, não mais a grandiosidade das vitórias alcançadas sob várias dificuldades, mas sim, aspectos não gloriosos, mas de vital importância para a gênese de uma história desvinculada de estereótipos, que se presta a assumir um maior compromisso com a veracidade dos fatos e da transmissão dos mesmos.

\footnotetext{
${ }^{319}$ MAXIMIANO, César Campiani. Barbudos, sujos e fatigados: soldados brasileiros na Segunda Guerra Mundial. São Paulo: Grua, 2010. p. 360 e 361.

${ }^{320}$ SILVERIA, Joaquim Xavier. A FEB por um soldado. Biblioteca do Exército, Rio de Janeiro. 2001. p. 253.
} 


\section{FONTES}

\section{A) PRIMÁrias}

\section{1- LEGISLAÇÃ̃}

BRASIL, Constituição (1824). Constituição do Império do Brazil. Carta da lei, de 25 de março de 1824/ Otaciano Nogueira- Brasília/DF: Senado Federal e Ministério da Ciência e Tecnologia, Centro de Estudos Estratégicos, 1999. 122 p.- Coleção Constituições Brasileira; v.1.

BRASIL, Constituição (1891). Constituição da República dos Estados Unidos do Brasil, de 24 de fevereiro de 1891/ Aliomar Baleeiro- Brasília/DF: Senado Federal e Ministério da Ciência e Tecnologia, Centro de Estudos Estratégicos, 1999. 122p.- Coleção Constituições Brasileira; v.2.

BRASIL, Constituição (1934). Constituição da República dos Estados Unidos do Brasil, de 16 de julho de 1934/ Ronaldo Poletti- Brasília/DF: Senado Federal e Ministério da Ciência e Tecnologia, Centro de Estudos Estratégicos, 1999. 194p.- Coleção Constituições Brasileira; v.3.

BRASIL, Constituição (1937). Constituição dos Estados Unidos do Brasil, de 10 de novembro de 1937/ Walter Costa Porto- Brasília/DF: Senado Federal e Ministério da Ciência e Tecnologia, Centro de Estudos Estratégicos, 1999. 144p.- Coleção Constituições Brasileira; v.4.

BRASIL, Constituição (1946). Constituição dos Estados Unidos do Brasil, de 18 de setembro de 1946/ Aliomar Baleeiro e Barbosa Lima Sobrinho- Brasília/DF: Senado Federal e Ministério da Ciência e Tecnologia, Centro de Estudos Estratégicos, 1999. 134p.- Coleção Constituiçõoes Brasileira; v.5.

BRASIL, Constituição (1967). Constituição da República Federativa do Brasil, de 24 de janeiro de 1967/ Themístocles Brandão Cavalcanti, Luiz Navarro de Brito e Aliomar Baleeiro- Brasília/DF: Senado Federal e Ministério da Ciência e Tecnologia, Centro de Estudos Estratégicos, 1999. 186p.- Coleção Constituições Brasileira; v.6.

BRASIL, Constituição (1969). Emenda Constitucional de 1969, de 17 de outubro de 1969/ Walter Costa Porto- Brasília/DF: Senado Federal e Ministério da Ciência e Tecnologia, Centro de Estudos Estratégicos, 1999. 157p.- Coleção Constituições Brasileira; v. VI a.

BRASIL, Constituição (1988). Constituição da República Federativa do Brasil: promulgada em 5 de outubro de 1988: atualizada até a Emenda Constitucional $\mathrm{n}^{\mathrm{o}} 19$, de 22-11-1998. 18. ed. rev. e ampl. São Paulo: Saraiva, 1998.

BRASIL, Decreto $\mathrm{n}^{\mathrm{o}} 20.062$, de 03 de dezembro de 1945. Concede indulto a oficiais, praças e civis, que fizeram parte integrante da F.E.B., ou a ela prestaram serviços, quando em operações na Itália, já condenados ou não, cujos crimes não são de natureza infamante. Diário Oficial [da] República Federativa do Brasil, Brasília/DF, 03 dez. 1945. Disponível em: 〈http: //www.presidencia.gov.br>. 
BRASIL, Decreto-Lei nº 6.396, de 01 de abril de 1944. Organiza a Justiça Militar junto às Forças Expedicionárias e regulariza seu funcionamento. Diário Oficial [da] República Federativa do Brasil, Brasília, DF, 01 abril 1944. Disponível em: <http: //www.presidencia.gov.br>.

BRASIL, Decreto-Lei no 6.509, de 18 de maio de 1944. Cria, na Reserva de $1^{\text {a }}$ Classe do Exército, um Quadro Especial para os Membros da Justiça Militar da Força Expedicionária Brasileira. Diário Oficial [da] República Federativa do Brasil, Brasília, DF, 18 maio 1944. Disponível em: 〈http: //www.presidencia.gov.br>.

BRASIL, Decreto-Lei no 7.057, de 20 de novembro de 1944. Altera o Decreto-Lei n. 6.396 que organiza e regula o funcionamento da Justiça junto as Forças Expedicionárias. Diário Oficial [da] República Federativa do Brasil, Brasília, DF, 20 nov. 1944. Disponível em: <http: //www.presidencia.gov.br>.

BRASIL, Decreto-Lei no 8.443, de 26 de dezembro de 1945. Extingue os órgãos da Justiça Militar organizada pelo Decreto-Lei n. 6.396, de 1 de abril de 1944 e dá outras providências. Diário Oficial [da] República Federativa do Brasil, Brasília/DF, 26 dez. 1945. Disponível em: <http: //www.presidencia.gov.br>.

BRASIL. Lei $\mathrm{n}^{\circ}$ 244, de 11 de setembro de 1936. Institui o Tribunal de Segurança Nacional. Brasília, DF. Disponível em: http://www6.senado.gov.br/sicon/ExecutaPesquisaLegislacao.action. Acesso em $\underline{01.05 .2016}$.

BRASIL. Lei no 110, de 28 de dezembro de 1937. Dispõe sobre o recurso de decisões do Tribunal de Segurança Nacional. Brasília, DF. Disponível em: http://www6.senado.gov.br/sicon/ExecutaPesquisaLegislacao.action. Acesso em $\underline{01.05 .2016 .}$.

SUPERIOR TRIBUNAL MILITAR. Regulamento do Superior Tribunal Militar Disponível em: <http://www.stm.gov.br>. Acesso em: 23 de janeiro de 2016.

\section{2- MEMÓRIAS}

BRAYNER, Mal. Floriano de Lima. A verdade sobre a FEB: memórias de um chefe de Estado-Maior na campanha da Itália. Rio de Janeiro: Civilização Brasileira, 1968.

CIDADE, Francisco de Paula. A Justiça Militar na FEB (Do Diário de Um Expedicionário). Rio de Janeiro: Nação Armada, 1945.

Documentário: “Garrafas ao mar: a víbora manda lembranças". Disponível em: https://archive.org/details/GarrafasAoMar (acesso em 22.09.2016).

Entrevista com o Marechal Levy, em sua casa no Rio de Janeiro, in: STM em Revista, Edição “60 anos da atuação da Justiça Militar na Segunda Guerra”.

FREITAS, Ricardo. Memória histórica do Ministério Público Militar.- Brasília: MPM, 2012. 
Histórias de Vida/ Coordenação: Centro de Memória do MPM; organização: Gunter Axt.- Brasília, 2016.

MASCARENHAS DE MORAES, João Baptista. A FEB pelo seu Comandante. Rio de Janeiro: Biblioteca do Exército Ed., 2005.

SALUN, Alfredo Oscar. Zé Carioca vai à guerra: Histórias e Memórias sobre a FEB. Editora: Pulsar, 2004.

SILVEIRA, Joaquim Xavier da. A FEB por um soldado. Rio de Janeiro: Biblioteca do Exército, 2001.

Síntese biográfica dos Procuradores-Gerais da Justiça Militar. Resumo histórico do Ministério Público Militar. Brasília: Serviço Gráfico do DPF, 1995.

Procuradores-Gerais de Justiça Militar 1920-2016/ Centro de Memória do MPM.Brasília, 2016.

\section{3- DOCUMENTOS}

Arquivo Histórico do Exército- AHEx. $1^{\text {a }}$ D.I.E- Relatórios.

Boletim Interno $n^{\circ} 126$, de 6-5-1945, da $1^{\text {a }}$ DIE.

Boletim Interno da $1^{\text {a }}$ D.I.E, $n^{\circ} 75$, de 16-III-945, Item XXIII.

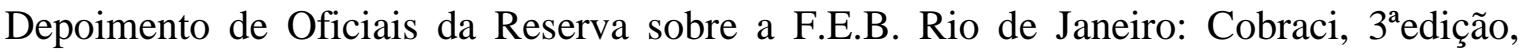
[s.d.].

Documentos inimigos apreendidos- AHEx, Caixeta 30.

Documentos recebidos da $1^{\text {a }}$ Seção da FEB- AHEx, Pasta 27, Caixeta 25.

Documentos recebidos da $1^{\text {a }}$ Seção da FEB- AHEx, Pasta 28, Caixeta 30.

Estudos e impressões sobre o inimigo- Arquivos da 2a Seção- AHEx, Caixeta 25.

Força Expedicionária Brasileira- Relatório Secreto. Volumes I, II e III- 1943-1945.

Hemeroteca- Diário do Congresso Nacional- Seção I. Ano VIII.

Legião Paranaense do Expedicionário, Roteiro da Força Expedicionária Brasileira na Campanha da Itália, Imprensa Oficial, s/d.

Nota de Comando $\mathrm{n}^{\circ}$ 20, de 30 de abril de 1945, publicada no Boletim Interno $\mathrm{n}^{\circ} 126$, da $1^{\mathrm{a}} \mathrm{DIE}$, de 06 de maio de 1945.

Relatório sumário das atividades do Serviço de Saúde da $1^{\text {a }}$ D.I.E, desde o desembarque na Itália do Escalão Avançado até a cessação das hostilidades- AHEx. Livro 151. 


\section{B) BIBLIOGRAFIA}

ALBINO, Daniel. Cobras fumando: a Força Expedicionária Brasileira Brasileira na Campanha da Itália: In: o Brasil e a Segunda Guerra Mundial. Rio de Janeiro: Multifoco, 2010.

ALBUQUERQUE, Bento Costa Lima Leite de. A Justiça Militar na Campanha da Itália. Fortaleza: Imprensa Oficial, 1958.

ALMEIDA, Cel. Adhemar Rivermar de. Montese: Marco Glorioso de uma trajetória, $1^{\mathrm{a}}$-Ed., BIBLIEX, 1985.

ALVES, Vágner Camilo. Da Itália à Coréia: decisões sobre ir ou não à guerra. Belo Horizonte: Editora UFMG; Rio de Janeiro: IUPERJ, 2007.

ALMEIDA, Paulo Roberto. Relações Internacionais e Política Externa do Brasil. Porto Alegre: Editora da Universidade Federal do Rio Grande do Sul. 1998.

ARAGÃO, José Campos de. "O Brasil na Segunda Guerra Mundial”. Revista do Instituto de Geografia e História Militar do Brasil, v. LV, 1984, Rio de Janeiro.

ASSIS, Jorge César. Direito militar: aspectos penais, processuais penais e administrativos. Curitiba: Juruá, 2007.

Comissionamento em postos militares de Juízes- Auditores, membros do Ministério Público Militar e da Defensoria Pública da União, por ocasião do Tempo de Guerra. Revista de Direito Militar. Florianópolis: Associação dos Magistrados das Justiças Militares Estaduais, n 38, novembro/dezembro, 2002.

AZEVEDO, Carlos Eduardo Franco; Gláucio Érico de Almeida Silva, Eros José Sanches (organizadores). $5^{\circ}$ Batalhão de engenharia de combate blindado: 100 anos de história - Tomo II. - União da Vitória (PR): UNIUV, 2015.

BANDEIRA, Esmeraldino. Curso de Direito Penal Militar. Rio de Janeiro: Francisco Alves, 1915.

Direito, justiça e processo militar. $2^{\mathrm{a}}$. ed. Rio de Janeiro: F.

Alves, 1919.

BARBOSA, Raymundo Rodrigues. História do Superior Tribunal. Rio de Janeiro: Departamento de Imprensa Nacional, 1952.

BARRETO, Adalberto. A Justiça Militar em Tempo de Guerra. Rio de Janeiro: A Defesa Nacional, 1947.

BARROSO FILHO, José. Justiça Militar da União. Disponível em: <http://www1.jus.com.br/doutrina/texto.asp?id=1570>. Acesso em: 11.03.2016.

BASBAUM, Leôncio. História sincera da República. V. III. São Paulo: Alfa-Omega, 1976. 
BASTOS, Paulo Cesar. Superior Tribunal Militar: 173 anos de história. Brasília: Superior Tribunal Militar, 1981.

BENTO, Claudio Moreira (Org.) et GIORGIS, Luiz Ernani Caminha. Brasil- Lutas contra invasões, ameaças e pressões externas (Em defesa de sua Integridade, Soberania, Unidade, Independência e Integração; e da Liberdade e Democracias Mundiais). Resende-RJ: FAHIMTB/IHTRGS, 2014.

BEVILAQUA, Clóvis. Código Penal Militar: esclarecimentos preliminares. Revista do Superior Tribunal Militar, Brasília, DF, v. 5, n. 6, 1980; o artigo foi escrito em 1911.

BOBBIO, Norberto; Nicola Matteucci e Gianfranco Pasquino. Dicionário de Política. Vol. I. Trad. Carmen C, Varriale et ai; coord. Trad. João Ferreira. Brasília: Editora Universidade de Brasília, 11 a ed., 1998.

BOITEUX, Nylson Reis. A Justiça Militar no Brasil. Revista A Defesa Nacional, Rio de Janeiro, $\mathrm{n}^{\circ} .786,1^{\circ}$ quad. 2000.

BONALUME NETO, Ricardo. A nossa Segunda Guerra: os brasileiros em combate, (1942-1945). Rio de Janeiro: Expressão e Cultura, 1995.

BOURnE, V. Richard. Getúlio Vargas- A Esfinge dos Pampas. São Paulo: Geração Editorial, 2012.

BRANDI, Paulo. Vargas: da vida para a história. Rio de Janeiro: Zahar, 1983.

BURNS, E. Bradford. A History of Brazil. 3ed. Nova York: Columbia University Press, 1993.

CALMON, Pedro. História do Brasil. Rio de Janeiro: José Olympio Editora, 1961.

CAMÕES, Luis de. Os Lusíadas. Rio de Janeiro: Edições de Ouro, 1995.

CAMPBELL, Keith. Brazil in the Second World War. Pretoria, South Africa: Unisa Centre for Latin American Studies, 1992.

CAMPOS JÚNIOR, José Luiz Dias. Direito Penal e Justiça Militares. Curitiba: Juruá, 2001.

CARTIER, Raymond. A Segunda Guerra Mundial. Rio de Janeiro: Larousse do BrasilParis Match, 1967.

CARVALHO, José Murilo de. Forças armadas e política no Brasil. Rio de Janeiro: Jorge Zahar Editora, 2005.

Civilização Brasileira, 2001.

Os bestializados: o longo caminho. Rio de Janeiro:

CASTELO BRANCO, Manoel Thomaz. O Brasil na Segunda Guerra Mundial. Rio de 
Janeiro: Biblioteca do Exército Editora, 1960.

CASTRO, Therezinha de. José Bonifácio e a Unidade Nacional. Rio de Janeiro: Biblioteca do Exército Editora, 1984.

CERVO, Amado Luiz. As relações históricas entre o Brasil e a Itália. Brasília: UNB, 1991.

CIDADE, Francisco de Paula. Algumas observações sobre o funcionamento da Justiça Militar brasileira no Teatro de Operações da Itália. Revista do Superior Tribunal Militar. Brasília: STM, v.11/13, 1989/1991.

Coletânea de Estudos Jurídicos. Publicação em comemoração ao Bicentenário da Justiça Militar no Brasil./ Maria Elizabeth Guimarães Teixeira Rocha, Zilah Maria Callado Fadul Petersen, coordenadoras; Samantha Ribeiro Meyer -Pflug, colaboradora.- Brasília: Superior Tribunal Militar, 2008.

CONN, Fairchild. The Framework of Hemisphere Defense. Superintendent of Documents, U.S. Government Printing Office, 2002.

CORSI, Francisco Luiz. Estado Novo: política externa e projeto nacional. São Paulo: Unesp, 2000.

COSTA, Octavio. Trinta anos Depois da Volta. Rio de Janeiro, Biblioteca do Exército Editora, 1976.

D' ARAUJO, Maria Celina S. da. Militares, democracia e desenvolvimento: Brasil e América do Sul. Rio de Janeiro: FGV, 2010.

DRAY, William. Laws and Explanations in History. Londres: Oxford University Press, 1957.

DROKE, Maxwell. Good-by to G.I.: How to be a sucessful civilian. New York: AbindonCokesbury Press, 1945.

FACHIN, Odília. Fundamentos de Metodologia. São Paulo: Saraiva, 2002.

FAGUNDES, João Batista. A justiça do comandante. $2^{\mathrm{a}}$. ed. rev. e atual. Brasília, DF, 2002.

FAORO, Raymundo. Os donos do poder: formação do patronato político brasileiro. 6 . ed. Porto Alegre: Globo, 1984.

FAUSTO, Boris. Getúlio Vargas. São Paulo: Companhia das Letras, 2006.

. História do Brasil. 2 ed. São Paulo: Edusp, 1995.

FERRAZ, Francisco César Alves. A guerra que não acabou: a reintegração social dos veteranos da Força Expedicionária Brasileira (1945-2000). 2003. Tese DoutoradoFaculdade de Filosofia, Letras e Ciências Humanas- FFLCH, Universidade de São Paulo, 
São Paulo, 2002.

As guerras mundiais e seus veteranos: uma abordagem comparativa. Revista Brasileira de História. Vol 28, p. 463-486, 2008.

Janeiro: Zahar Editora. 2009.

Os Brasileiros e a Segunda Guerra Mundial. Rio de

FIGUEIREDO, Nébia Maria Almeida de. Método e metodologia na pesquisa científica.

São Paulo: Yendis, 2007.

GAMBONE, Michael D. The Greatest Generation comes home. The veteran in American society. Texas: A\&MUniversity Press, 2005.

GOMES, Laurentino. 1808: como uma rainha louca, um príncipe medroso e uma corte corrupta enganaram Napoleão e mudaram a história de Portugal e do Brasil. São Paulo: Editora: Planeta do Brasil, 2007.

GODINHO, Gualberto. Do direito e da implantação da justiça militar no Brasil. Disponívelem: $<$ http://www.buscalegis.ufsc.br/arquivos/Do_direito_e_da_implatacao_da_j ustica_militar_no_brasil.html >. Acesso em: 11.03.2016.

HIBBERT, Christopher. Mussolini, the rise and fall of il Duce. Nova York: Palgrave Macmillan, 2008.

HILTON, Stanley. Oswaldo Aranha- Uma Biografia. Rio de Janeiro: Objetiva, 1994.

HERRERA, Heitor Almeida. A Estratégia dos Aliados na Segunda Guerra Mundial. Rio de Janeiro: Biblioteca do Exército Editora, 1961.

INNOCENTI, Marco. Ciano- Il fascista che sfidò Hitler. Milano: Ugo Mursia, 2013.

KENNET, L. G.I. The American Soldier in World War II. Norman: University of Oklahoma Press, 1997.

LAPORT, William Pereira. A incompetência da justiça militar para processar e julgar civis por crimes militares impróprios em tempo de paz. 2013. Monografia (Bacharelado em Direito) —Universidade de Brasília, Brasília, 2013.

LIMA, Manoel de Oliveira. D. João VI no Brasil. Rio de Janeiro: Topbooks, 1996.

LINS, Maria de Lourdes F. A Força Expedicionária Brasileira: uma tentativa de interpretação. USP, 1975 (dissertação de mestrado).

LOBÃO, Célio. Direito Penal Militar atualizado. Brasília, DF: Brasília Jurídica,1995.

LOBO, Hélio. Sabres e togas: a autonomia judicante militar, $2^{\mathrm{a}}$. ed. Rio de Janeiro: Borsoi, 1960.

LOPES, Adriana; MOTA, Carlos Guilherme. História do Brasil: uma interpretação. 
São Paulo: SENAC, 2008.

LOUREIRO NETO, José da Silva. Direito Penal Militar. 4a . ed. São Paulo: Atlas, 2001.

MARQUES, Antonio. Aperfeiçoamento da Justiça Militar. Rio de Janeiro: A Defesa Nacional, 1966.

MARQUES, Antônio Henrique Rodrigo de Oliveira, História de Portugal, Volume I, Edições Àgora, Lisboa, 1973.

MAXIMIANO, Cesar Campiani: Barbudos, sujos e fatigados: soldados brasileiros na Segunda Guerra Mundial. São Paulo: Grua, 2010.

MAZZILI, Hugo Nigro. Introdução ao Ministério Público. $7^{\text {a }}$ ed. Saraiva, 2008.

MCCANN, Frank D. A Aliança Brasil Estados Unidos (1937-1945). Rio de Janeiro: BIBLIEX, 1995.

MEIRA MATTOS, Carlos de. O General Mascarenhas de Moraes e sua Época. Rio de Janeiro: Biblioteca do Exército Editora, 1983.

MELLO, Francisco Batista de. O medo, a disciplina e a liberdade. A Defesa Nacional, Rio de Janeiro, n. 699, Jan./Fev. 1982.

MELlO, José Luiz Ribeiro (org.). A legislação do ex-combatente. Compilada e organizada pelo Conselho Nacional das Associações de Ex-Combatentes do Brasil. Rio de Janeiro: Ed. Expedicionario, 1978.

MELLO, Washington Vaz de. A Justiça Militar na Força Expedicionária Brasileira. Rio de Janeiro: Revista do Exército Brasileiro, 1984.

Ministério da Marinha. História Naval Brasileira. $5^{0}$ volume, Tomo II. Rio de Janeiro: Serviço de Documentação da Marinha, 1985.

MONTEIRO, Marcelo. U-507: o submarino que afundou o Brasil na Segunda Guerra Mundial. Santos-Salto, SP: Schoba, 2012.

MONTI, Luisa Sturani. Antologia della Resistenza. Torino: Centro del Libro Popolare, 1951.

MOURA, Gerson. Autonomia na dependência - A política externa brasileira de 1935 a 1942. Rio de Janeiro: Nova Fronteira, 1980.

Sucessos e ilusões: relações internacionais do Brasil durante e após a segunda guerra mundial. Rio de Janeiro: FGV, 1991.

NETO, Lira. Getúlio 1930-1945: Do governo provisório à ditadura do Estado Novo. São Paulo: Companhia das Letras, 2013.

NUNES, Roberto. "Notas sobre a Viagem do Primeiro Escalão da FEB para a Itália". 
Revista do Exército Brasileiro, v. 120, n. 4, out./dez. 1983, p.120-124.

O Cruzeiro do Sul. "Edição Comemorativa dos 30 anos da Poupex, dos 80 anos do Clube Filatélico do Brasil e dos 200 anos da Academia Militar das Agulhas Negras, Aman"/Roberto Mascarenhas de Moraes, organizador.- 2ed. Rio de Janeiro: Léo Christiano Editorial, Biblioteca do Exército, 2011.

PACHECO, Cláudio. Tratado das constituições brasileiras. Revista de Informação Legislativa, ano V, nº 17, Jan. / Mar., Rio de Janeiro: 1968.

PEDROSA, José Júlio. Competência da Justiça Militar da União. Disponível em:<http:<www.neofito.com.br/artigos/art01/milit13.htm>. Acesso em: 11.08.2015.

PENNA, Lincoln de Abreu. República Brasileira: Nova Fronteira, 1999.

PESSÔA, Ruy de Lima. Superior Tribunal Militar. Revista do Superior Tribunal Militar. Brasília, 1988.

PLESCH, Dan. America, Hitler and the UM- How the Allies won World War II and Forged a Peace. Londres: I. B. Taurus, 2011.

REIS, Everaldo de Oliveira. A Justiça Militar Brasileira. Rio de Janeiro: Revista do Exército Brasileiro, 1996.

RICHARDSON, Roberto Jarry. Pesquisa Social Métodos e Técnicas. $3^{\text {a }}$ Edição. São Paulo: Editora Atlas S.A., 1999.

ROBERTS, Geoffrey. Stalin's General- The Life of Georgy Zhykov. Londres: Icon Books, 2012.

ROHWER, Jurgen. "Operações Navais da Alemanha no Litoral do Brasil durante a Segunda Guerra Mundial”. Navigator, $n^{\circ}$. 18, 1982, Rio de Janeiro.

ROMEIRO, João. Um velho advogado na Justiça Militar. Belo Horizonte: Imprensa Oficial, 1962.

ROMEIRO, Jorge Alberto. Curso de Direito Penal Militar: parte geral. São Paulo: Saraiva, 1994.

Disponível

O Código Penal Militar: esse grande desconhecido, em: <http://www.buscalegis.ccj.ufsc.br/arquivos/o_codigo_penal_militar_esse_grande_des conhecido>. Acesso em: 11.08.2015.

ROSA, Paulo Tadeu Rodrigues. Organização da Justiça Militar. Disponível em: <http://www1.jus.com.br/doutrina/texto.asp?id=1569>. Acesso em: 10.04.2016.

ROSS, Davis R.B. Preparing for Ulysses: Politics and Veterans during Worl War II. Nova Iorque e Londres. Columbia University Press, 1969. 
RYAN, Cornelius. The Last Battle. Estados Unidos: Popular Library, 1966.

SAMPAIO, Carlos Alberto H. de Oliveira. "Justiça Militar brasileira”, in Revista do Superior Tribunal Militar, Brasília, 1976, s/n, p. 65-81.

SANDER, Roberto. O Brasil na mira de Hitler: A história dos afundamentos de navios brasileiros pelos nazistas. Rio de Janeiro: Objetiva, 2007.

SCHNAIDERMAN, Boris. Guerra em surdina: história do Brasil na segunda Guerra Mundial. 3 ed., São Paulo: Brasiliense, 1995.

SEITENFUS, Ricardo. O Brasil vai à guerra- O processo de envolvimento brasileiro na Segunda Guerra Mundial. São Paulo: Manole, 2003.

SEMIRIAGA, M. I. Missão libertadora das forças armadas soviéticas na Segunda Guerra Mundial. Rio de Janeiro: Livraria Ciência e Paz, 1985.

SEVERINO, Antonio Joaquim. Metodologia do Trabalho Científico. São Paulo: Cortez, 2000.

SILVEIRA, Joel. Segunda Guerra Mundial: todos erraram, inclusive a FEB. Rio de Janeiro: Espaço e Tempo, 1989.

SILVEIRA, Renato de Mello Jorge. A nova competência da Justiça Militar. Disponível em: <http://buscalegis.ccj.ufsc.br/arquivos/a_nova_competencia_da_justiça_militar.html>. Acesso em: 21.06.2015.

SKIDMORE, TE. Brasil: Getúlio Vargas a Castelo Branco (1930-1964). $7^{\text {a }}$ ed. Rio de Janeiro (RJ): Paz e TERRA; 1996.

SODRÉ, Nelson Werneck. Formação histórica do Brasil. 5a ed. São Paulo: Editora Brasiliense, 1969.

Popular, 2010.

História militar do Brasil. 2 ed. São Paulo: Expressão

STM em Revista, Ano 2, no 2, Julho-Dezembro de 2005, Edição “60 anos da atuação da Justiça Militar na Segunda Guerra".

STOUFFER, Samiel. The American Soldier, Vol. 1: Adjustment during army life. Princeton: Princeton University Press, 1949.

The American Soldier. Vol 2: Combat and its aftermatch.

Princeton: Princeton University Press, 1949.

STUDART FILHO, Paulo. Corpo Jurídico Militar para o Exército. Rio de Janeiro: Escola de Comando e Estado-Maior do Exército. Monografia (MO 0089), 1996.

TEIXEIRA, Sílvio Martins. Código Penal Militar. Rio de Janeiro: Freitas Bastos, 1946. 
TElHADA, Paulo Adriano L.L. A Polícia de São Paulo nos Campos da Itália. KMK Gráfica e Editora Ltda. 2001.

TORRES, Luis Cláudio Alves. Prática do Processo Penal Militar: doutrina e jurisprudência. 2. ed. Rio de Janeiro: Destaque, 1996.

UNITED STATES CONGRESS. Servicemen's Readjustment Act. Washington D. C, 1944.

Disponível em:

http://www.milestonedocuments.com/documents/view/servicements-readjustment-act

Acessado em: 07.12.2015.

VIANA, Hélio. História do Brasil. São Paulo: Melhoramentos, 1967.

VIGEVANI, Tulo. Questão nacional e política exterior. Um estudo de caso: formulação da política internacional do Brasil e motivações da Força Expedicionária Brasileira. São Paulo, 1989, tese de doutorado em História, FFLCH-USP.

VOGEL, R.J. The Veterans Benefits Administration: An Organization History: 17761994. Washington DC, 1995.

WAACK, William. As duas faces da glória: a FEB vista pelos seus aliados e inimigos. Rio de Janeiro: Nova Fronteira, 1985.

WECTER, Dixon. When Johnny comes marching home. Cambridge, Massachussets: Houghton Mifflin Company, 1944. 


\section{ANEXOS}

I

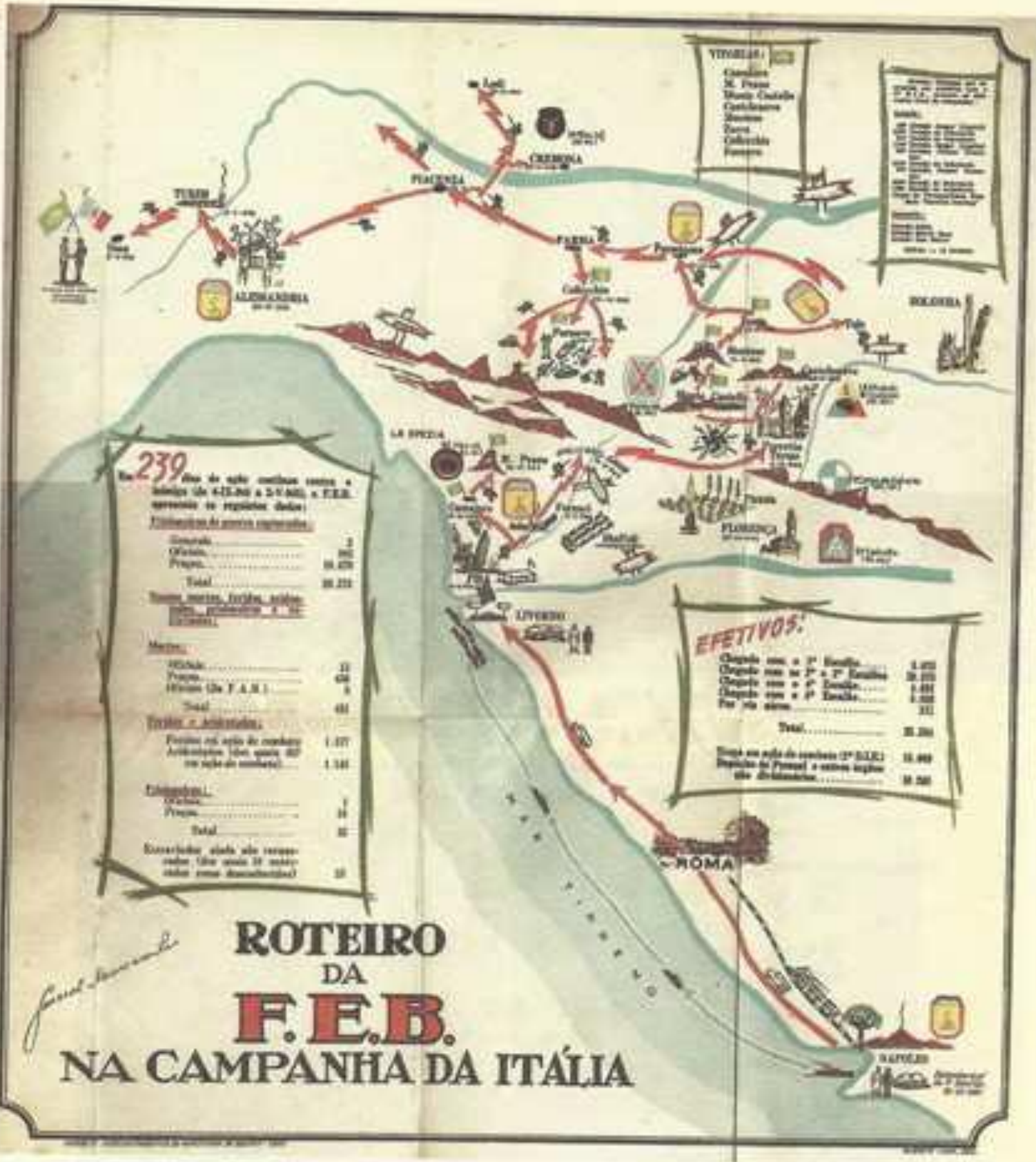

Roteiro da FEB, originalmente pablicado no Ria de Janeimo em 1945

e inclualdo no relato de camponha de autoria da General Mascarenhas de Monais. Fonte: A FEB Pelo Seu Comandante 
Alvará de 1808

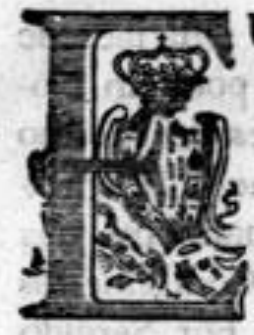

U O PRINCIPE REGENTE Faço faber aos que o pefente Alvarí com força de Lei virem : Que fendo muito conver. niente ao Bem do Meu Real Serviço, que rudo quanto refpeita á boa ordem, e regularidade da Dif́ciplina Militar, Economia, e Regulamento das Minhas Forças tanto de Terra, como de Mar, fe mantenha no melhor eftado; por que delle depende a energia, e confervação das mesmas Forças, que feguräo a tranquillidade, e defeza dos Meus Eftados: E fendo muitos os Negocios defta natureza, que por Minhas Leis, e Ordens fão da competencia dos Confelhos dê Guerra, do Almirantado, e do Ultramar na parte Militar sómente, onde fenão podem deeidir, por Me achar refidindo nefla Capital, os quaes näopodem eftar demorados lem manifefto detrimento do intereffe público, e prejuizo dos Meus. Fieis Vaffallos, que tem a honra de fervir-Me nos Meus Exercitos, e Armadas: E devendo outrofim dar-fe providencias mais adaptadas ás actuaes circunftancias para a boa Administraçăo da Juftiça Criminal no Conselho de Juftiça, que fe fórma nos Confelhos de Guerra, e do Almiranrado, a fim de que fe terminem os Proceflos quanto antes, e com a regularidade, e exactidăo, que convem: Para obviar, e remover eftes, é outros incon. venientes: Sou Servido Determinar o seguinte.

- I. Haverá néfta Cidade hum Confelho Supremo Militar, que entenderá em todas as materias, que pertenciāo ao Confelho de Guerra, e aa do Ultramar na parte Militar fómente; que fe comporá dos Officiaes Generaes do Meu Exercito, e Armada Real, que já sāo Confelheiros de Guerra, e do Almirantado, e 
que fe achăo nefta Capital, e dos outros Officiaes de huma, e ourra Arma, que Eu Houver por bem Nomear, devendo eftes ultimos fer Vogaes do mesmo Confelho em todas as materias, que nelle fe trata$\mathrm{rem}$, fem que com tudo gozem individualmente das Regalias, e Honras, que competem aos Confellheiros de Guerra, que já o são, ou que Eu For Servido Despachar para o fururo com aquelle Titulo por huma Graça efpecial : E ifto mefmo fe deverá entender a refpeito do Titulo do Neu Confelho, de que gozäo os Confellheiros do Almirantado pelo Alvara de feis de Agofo de mil fetecentos noventa e cinco, e $\alpha$ de trinta do mefmo mez e anno.

II. Seria da Competencia do Confelho Supremo Militar todos os Negocius', em que em Lisboa entendiäo os Confelhos de Gurenta, do Almirantado, e do Ultramar na parte Militar fómente, y el todos os mais, que Eu Houver por bem Encarregar-lhe; e poderá o mefmo confultar-Me tudo quanto julgar conveniente para miellhor Economia, e Difciplina do Med Exercito, \& Marinha. Pelo Expediente, e Secretaria do mefmo Conifelho fe expediraiou todas as Patentes affim das Tropas de Linlia, Armada Real, e Briga da, come dos Córpos Milicianos, e Ordenanças, pela mefma fórma, e maneira, por que fexpedião até agora pelas Secretarias de Guerra, do Álmirantado; e do Conselho Ultramarino.

biII Regular-setha o Confelho pelo Regimento de vinte e dous de Dezembro de mil seiscentos quatenta e trés, e por todas as mais Refoluçōes, e Ordéns Régias, poo que fe rege o Confeltho de Guerra de Lisboa, e pelo Alvará de Regimento de vinte e seis de Outubro de mil fetecentos noverita e feis, 
e Determinaçōes Minhas pofteriores; em tudo quì for applicavel ás actuaes circunftancias: E quandb aconteça occorrer algum cafo, que ou nāo efteja providenciado pela Legislação exiftente, ou ella nắ poffa quadrar-lie, o Confelho Mo proporá pelas Secretarias de Eftado competentes, apontando as providencias, que the parecerem mais proprias, para Eu Deliberar o que mais Me Aprourer.

IV. Para o Expediente do Supremo Confelho Militat haverá hum Secretario, que Sou Servido Crear, o qual vencerá annualmente tres mil cruzados de ordenado, além do foldo, fe o tiver: E para ajudar efta, e as mais Defpezas do Confelho; Ordeno, que na Minha Real Fazenda fe entregue o meio soldo de cada humá Patente, que pelo Confelho fe houver de paffar, e o Direito do Sello competente; devendo conftar na Secretaria do mefmo Confelho haver-fe pago eftas defpezas primeiro que fe paflem as Patentes.

V. O Confelho Supremo Vilitar tera as suas Sefsōes todas as fegundas feifas, e fabados dé tarde de cada femana, não fendo feriados, ou de guarda.

VI. Para o conhecimento, e decisāo dos Procef fos Criminaes, que fe formáo aos Reos, que gozăo dó Foro Militar, e que em virtude das Ordens Regias fe devem remetter ao Confelho de Guerra ainda fem appelação de Parte, ou por meio della, haverá o Confelho de Juftiça determinado, e regulado pelos Decretos de vinte de Agofto de mil fetecentos setenta e fete, de cinco de Outubro de mil fetecentos fetenta e oito, de treze de Agofto, e treze de Novem. bro de mil fetecentos e noventa; fazendo-fe para elle huma Sefsão todas as quartas feiras de tarde, $\star$ ii que 
que năอ forem dias feriados, ou de guarda, para efle conhecimento fómente.

vil. 0 Confelho de Juftiça fe comporá dos Con: felheiros de Guerra, Confellheirus do Almirantado, e mais Vogaes, e de tres Miniftros Togados, que Eu Houver de Nomear, dos quaes ferá hum a Re. lator, e os outros dous Adjuntos para $\mathbf{Q}$ defpacho de todos os Proceffos, que fe remettem ao Confetho para ferem julgados em ulvima Inftancia na forma acima expofta; e guardar-fe-ha para afua decisäo, e forma de conhecimento oque fe acha determinado no Decreto de treze de Novembro de mil setecentos e noventa, que interpreton os anteriores. E Hei por bem Revogar a dispofta na Carra Regia de vinte e nove de Novembro de mil oitocentos e feis, que creou os Confelhos de Juftiça nefte Eflada em cutras circunflancías.

VIII, Remetter-fe-hăo para ferem decididos no Con felho de Juftiça todos os Confelhos de Guerra, que fe formarem nos Corpos Vilitries defta Capitania, e de rodąs as mais do Brazil , á excepço da Pará, e Maranhāo, e dos Dominios Ultramarinos, pela geande diffancia, o difficuldade da navegaçäo para efta Capital, onde fe concinuaraó a praticar as Providencias, que houver a efte respeito.

IX. No julgato de todos eftes Proceffos guardaríó - que fe acha difpofto no Regulamento Militar, em vodas as Leis, Ordenanģas Milizares, Alvara de feis de Abril de mil e oitecentos, que dá força de Lei aus Artigos de Guerra eflabelecidos para oServiço, e Difciplina da Armada Real, Regimența Provifional por Mim Approvedo par Decreto de vinte de Junhó de mil fetec entos noventa e fés, e mais Refoluçäes 
Regias, e na Ordenanç̧a Noviffima de nove de Abril de mil oitocentos e cinco; obfervando-fe a difpofto na Carta Regia de dezanove de Fevereira de mil aitocentos e fete, que revogou a referida Ordenança, quanto á pena impofta pelo crime de resceira; e fimples Deferçio; pondo-fe em execuçio todas as Determinaçōes Regias, que não forem revogadas nefte Alvará.

X. O Confelho de Juftiça Supremo Militar fe ajuntará extrăordinariamente nąs quintas ffeias, quan. do pará éfe fim fur avifado, e-requerido pelo Juiz Relator do mefmo Confelho, para julgar em ultima Inftancia da validade das Prezas feitas por Embarcaçóes de Guerra da Armada Real, ou por Armado. res Portuguezes, na forma dos Alvarás de fete de Dezembro de mil fetecentos noventa e feis, nove de Maio de mil fetecentos noventa e fete, e qua* tro de Maio de mil oitocentos e cinco.

- El efle fe curiprirá tă inteirànente como nel. te fe contén. Pelo que; Nando au Cenfelho Süpre: mo Militar, General das Arras defta Capital; Gover nadores, e Capitães Generaes; Miniftros de Juftiça; e todas as mais Peffoas, a quem pertencef o conhecimento, e execução defte Alvará, que o cumpräo, e guardem, e façáo cumprir, e guardar tão inteira.

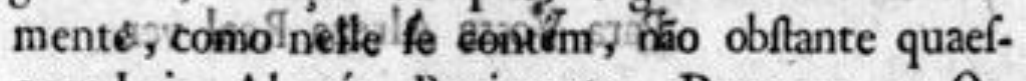
quer Leis, Alvarás, Regimentos, Decretos, ou Ordens em contrario; porque Hei todos, e todas por derogadas para efte effeito fómente, como fe dellas fizeffe individual, e expreffa mencijo, ficando aliás

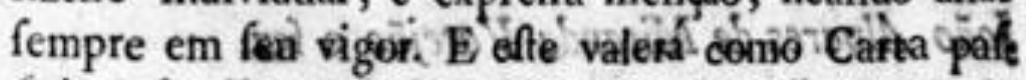
fada pela Chancellaria, ainda que por ella não hade paffar, e que o feu effeito haja de durar mais de

hum 
hum anno, fem embargo das Ordenações em contrario: Regiftando-fe em todos os lugares, onde fe coflumāo regiftar femelhantes Alvaris. Dado no $\mathrm{Pa}$ lacio do Rio de Janeiro em o primeiro de Abril de mil oitocentos e oito.

\section{PRINCIPE : : \\ D. Fernando Jose' de Portugal.}

sinith

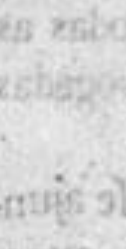

it mgrot cita sip

A Lvảrá com força de Lei, pelo qual Vossa Alte3a Real He Servido Crear hum Confellho Supremo Militar, e de Juftiga; na forma acima declarada.

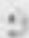

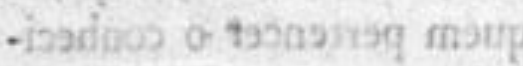

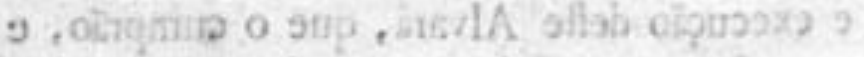

- Tisenp curisfido Para Vossa Alteza Real ver.

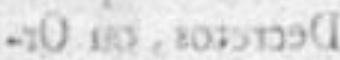

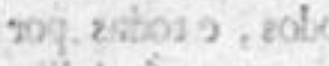

actlob st armos

Joäo Alvares de Miranda Varejäo o fez. obed ait

Re. 
Registado nefta Secretaria de Estado dos Nego. cios do Brazil no Livro I. de Leis, Alvarás, e Cartas Regias a fol. 69 Уे. Rio de Janeiro aos dezafete de Novembro de mil oitocentos e oito.

Jọäo Baptifta de Alvarenga Pimentel.

$\mathrm{Na}$ Impressäo Regia. 


\section{III}

\section{DECRETO-LEI Nº 6.396 - DE 1 DE ABRIL DE 1944 \\ Organiza a Justiça Militar junto às, Forças Expedicionárias e regulariza seu funcionamento}

O Presidente da República usando da atribuição que lhe confere o art. 180 da Constituição,

\section{decreta:}

Art. $1^{\circ}$ São órgãos da Justiça Militar, junto, as Forças Expedicionárias:

I - O Conselho Supremo de Justiça Militar;

II - Os Conselhos de Justiça;

III - Os auditores.

Art. $2^{\circ}$ Aos órgãos referidos no artigo anterior compete o processo e julgamento dos crimes praticados em zonas de operações militares ou em território estrangeiro, militarmente ocupado por Forças brasileiras, pela forma estabelecida nesta lei, ressalvado o disposto em convenções.

Parágrafo único. Consideram-se as Forcas Expedicionárias em operações militares desde o momento de seu embarque para o estrangeiro,

Art. $3^{\circ} \mathrm{O}$ Conselho Supremo de Justiça Militar compor-se á de dois oficiais generais, da ativa ou reserva, e um magistrado militar de carreira, de preferência do Supremo Tribunal Militar, nomeado pelo Presidente da República.

Parágrafo único. A presidência do Conselho Supremo de Justiça Militar será exercida pelo juiz de patente mais, elevada, de qualquer quadro, ou pelo mais antigo, em caso de Igualdade de posto.

Art. $4^{\circ}$ Junto ao Conselho Supremo de Justiça Militar, funcionará um procurador geral, escolhido pelo Presidente da República, dentre os membros do Ministério Público da Justiça Militar, e um advogado de ofício, designado pelo Ministro da Guerra.

Art. $5^{\circ} \mathrm{O}$ presidente do Conselho Supremo de Justiça Militar requisitará ao Ministro da Guerra o pessoal necessário ao serviço da Secretaria, designando o secretário, que será, de preferência, diplomado em direito.

Art. $6^{\circ} \mathrm{O}$ Conselho de Justiça compor-se-á do juiz militar de carreira (auditor) e dois Comandantes de Divisão, e de patente superior ou igual à do acusado, observado, na última hipótese, o princípio da antigüidade de posto.

$\S 1^{\circ}$ Esse Conselho será constituído para cada processo, e dissolver-se-á logo depois de terminado o julgamento, cabendo sua presidência ao juiz de patente mais elevada, ou mais antigo, em caso de igualdade de posto.

$\S 2^{\circ}$ Para o julgamento de oficial da Armada ou Aeronáutica, a nomeação deverá recair, quando possível, em oficiais das respectivas corporações. 
Art. $7^{\circ}$ Haverá, em cada Divisão das Forças Expedicionárias, duas ou mais auditorias.

$\S 1^{\circ}$ Cada auditoria compor-se-á de um auditor, um promotor, um advogado de ofício, um escrivão e escreventes, designados pelo Ministro da Guerra, dentre o pessoal efetivo ou substituto do quadro da Justiça Militar, exceto os escreventes, que serão praças graduadas, requisitadas pelo auditor.

$\S 2^{\circ}$ Um dos escreventes exercerá, por designação do auditor, as funções de oficial de justiça.

\section{DA COMPETÊNCIA}

Art. $8^{\circ}$ Ao auditor compete:

I - presidir instrução criminal dos processo em que forem réus praças, civis, ou oficiais até o posto de tenente-coronel, inclusive.

II - julgar as praças e civis.

Art. $9^{\circ}$ Ao Conselho de Justiça compete o julgamento dos oficiais até o posto de tenente-coronel, inclusive.

Art. 10. Ao Conselho Supremo de Justiça Militar compete;

I - processar e julgar, originariamente os oficiais generais e coronéis;

II - julgar as apelações interpostas das sentenças proferidas pelos auditores e Conselhos de Justiça;

III - julgar os embargos opostos às decisões proferidas nos processos de sua competência originária.

Art. 11. O inquérito ou documentos relativos ao crime será remetidos ao auditor mais antigo e distribuídos de conformidade com o art. 90 do Código da Justiça Militar.

Art. 12. Recebido o inquérito ou documentos, o auditor dará vista, imediata, ao promotor que, dentro de vinte e quatro horas oferecerá denúncia, contendo :

I - o nome do réu;

II - a exposição sucinta dos fatos;

III - a classificação do delito;

IV - a indicação das circunstâncias agravantes, expressamente definidas na lei penal, e de todos os fatos e circunstâncias que devem influir na fixação da pena;

V - a indicação de duas a quatro testemunhas. Parágrafo único. Será dispensado o rol de testemunhas, se a denúncia se fundar em prova documental.

Art. 13. O auditor mandará, uma vez recebida denúncia, citar incontinenti o réu e intimar as testemunhas, nomeando-lhe defensor o advogado de ofício, que terá vista dos autos, em cartório, pelo prazo de vinte e quatro horas, podendo, dentro dele, oferecer defesa escrita e juntar documentos.

Parágrafo único. O réu poderá dispensar a assistência do advogado de ofício, se estiver em condições de fazer a sua defesa. 
Art. 14. O réu preso será requisitado. O que estiver solto e ausentar-se sem permissão será processado e julgado à revelia, independentemente de qualquer outra formalidade.

Art. 15. Na audiência de instrução criminal, que será iniciada vinte e quatro horas após a citação qualificada do réu, que o não tenha sido no inquérito e se estiver presente proceder-se-á às inquirição das testemunhas de acusação. Se estas reportarem às declarações prestadas no inquérito, mencionar-se-á, apenas, o que retificarem ou aditarem.

$\S 1^{\circ}$ Em seguida, serão ouvidas até duas testemunhas de defesa. Se apresentadas no ato, e interrogado o réu.

$\S 2^{\circ}$ As testemunhas de defesa que forem militares poderão ser requisitadas, se o réu o requerer.

$\S 3^{\circ}$ Não se dará vista dos autos às partes, para alegações escritas.

$\S 4^{\circ}$ É dispensado o comparecimento do réu à audiência ou sessão de julgamento.

Art. 16. As questões preliminares ou incidentes que forem suscitados serão resolvidos, conforme o caso, pelo auditor ou Conselho de Justiça.

Art. 17. Se o promotor não oferecer denúncia, ou se esta for rejeitada, os autos serão remetidos ao Conselho Supremo de Justiça Militar, que proferirá a decisão final.

Art. 18. Sendo praça ou civil o réu, o auditor procederá julgamento em outra audiência, dentro de quarenta e oito horas. O promotor e o advogado terão, cada um, vinte minutos para fazer, oralmente, suas alegações. Após os debates orais, o auditor lavrará a sentença, dela mandando intimar o promotor e defensor do réu.

Art. 19. Nos processos a que responder oficial até o posto de tenente-coronel, inclusive, proceder-se-á ao julgamento pelo Conselho de Justiça, no mesmo dia de sua instalação.

$\S 1^{\circ}$ Prestado o compromisso pelos juízes nomeados, serão lidas, pelo escrivão, peças essenciais do processo e, depois dos debates orais, que não excederão ao prazo fixado no artigo anterior, passará o Conselho a deliberar em sessão secreta, devendo a sentença ser lavrada no prazo máximo de vinte e quatro horas.

$\S 2^{\circ}$ A nomeação dos juízes, que constará por certidão, dos solicitada pelo auditor ao Comandante da Divisão, com antecedência de vinte e quatro horas.

$\S 3^{\circ}$ Entre a audiência de instrução criminal e a solicitação de que, trata $\S 2^{\circ}$, não poderá mediar prazo superior a quarenta e oito horas.

$\S 4^{\circ} \mathrm{O}$ promotor e o defensor do réu serão intimados da presença no mesmo dia em que esta for assinada.

Art. 20. A falta de extrato de assentamentos ou da fé de ofício do réu poderá ser suprida por outros meios informativos.

Art. 21. Os órgãos da Justiça Militar, tanto em primeira como em segunda instância, poderão alterar a classificação do delito, sem todavia inovar a acusação.

Parágrafo único. Havendo impossibilidade de alterar a classificação do delito, o juiz ou tribunal mandará renovar o processo, com oferecimento de outra denúncia.

Art. 22. Quando, na denúncia, figurarem diversos réus, poderão mesmos ser processados e julgados, em grupos, em assim o aconselhar o interesse da justiça. 
Art. 23. Nos processos a que responder oficial general ou coronel, as funções do Ministério Público serão desempenhadas pelo Procurador Geral.

$\S 1^{\circ} \mathrm{O}$ relator do processo será o magistrado militar de carreira.

$\S 2^{\circ} \mathrm{O}$ oferecimento da denúncia, citação do réu, intimação de testemunhas, nomeação do defensor, instrução criminal, julgamento, lavratura e intimação do acórdão reger-se-ão, no que lhes for aplicará, pelas normas estabelecidas para o processo da competência do auditor e do Conselho de Justiça.

$\S 3^{\circ} \mathrm{Na}$ instrução criminal não será exercida a presença de todos os juizes,

Art. 24. Nos crimes de responsabilidade, oferecida a denúncia, o relator mandará intimar o denunciado, para apresentar defesa, dentro do prazo de três dias, findo o qual o Conselho Supremo de Justiça Militar decidirá sobre o recebimento, ou não, da denúncia.

Art. 25. Das decisões proferidas pelo Conselho Supremo de Justiça Militar, nos processo de sua competência originária, somente caberá recurso de embargos.

Art. 26. As funções de escrivão serão desempenhadas pelo secretário e as de oficial de justiça por uma praça graduada.

Art. 27. No processo de deserção observar-se-á o seguinte :

$\S 1^{\circ}$ Após o transcurso do prazo de graça, o comandante ou chefe, sob cujas ordens servir o oficial ou praça, fará lavrar um termo com todas as circunstâncias, assinando-o, com duas testemunhas, o qual equivalerá à formação da culpa.

$\S 2^{\circ}$ Fica abolido, para o oficial, o chamamento a que se refere o art. 268 do Código da Justiça Militar.

$\S 3^{\circ}$ Os documentos relativos à deserção serão remetidos, depois da apresentação ou captura do réu, ao auditor e permanecerão em cartório pelo prazo de vinte e quatro horas, com vista ao advogado de ofício, para apresentar defesa escrita, seguindo-se o julgamento pelo auditor ou Conselho de Justiça, conforme a caso.

\section{DOS RECURSOS}

Art. 28. Das sentenças de primeira instância caberá recurso de apelação para o Conselho Supremo de Justiça Militar.

Parágrafo único. Não caberá recurso das decisões proferidas sobre preliminar ou questões incidentes. Essas preliminares ou questões poderão, entretanto, ser renovadas na apelação.

Art. 29. A apelação será interposta, dentro de vinte e quatro horas, a contar da intimação da sentença ao promotor ou ao defensor do réu, revel, ou não.

Art. 30. O promotor apelará, obrigatoriamente:

I - da sentença de absolvição, se a lei cominar para o crime, no máximo, pena privativa da liberdade por tempo superior a seis anos;

II - quando se tratar de crime que a lei comine pena de morte e a sentença for absolutória, ou não aplicar a pena no máximo.

Art. 31. O advogado de ofício apelará, obrigatoriamente, das sentenças condenatórias. 
Art. 32. As razões de recurso serão apresentadas, com a petição, em cartório. Conclusos os autos ao auditor, este os remeterá, incontinenti, ao Conselho Supremo de Justiça Militar.

Art. 33. A aplicação será distribuída, por ordem de entrada dos processos, aos juízes, inclusive ao presidente, que fará a distribuição.

Art. 34. O Procurador Geral oficiará nos recursos interpostos peles promotores e naqueles em que, depois de examinados os autos pelo relator, verificar este a necessidade de sua audiência, devendo emitir parecer dentro de vinte e quatro horas.

Art. 35. O relator estudará os autos no intervalo de duas sessões.

Art. 36. Anunciado o julgamento, fará o relator, oralmente, a exposição do fato.

$\S 1^{\circ}$ Terminado o relatório, poderão o advogado do réu e o procurador geral fazer alegações orais, por dez minutos, cada um.

$\S 2^{\circ}$ Discutida a matéria pelo Conselho Supremo de Justiça Militar, proferirá este sua decisão, que se realizará em sessão secreta, se o réu estiver solto, ou quando assim for deliberado.

Art. 37. O resultado do julgamento constará de ata de que se juntará cópia ao processo, O acórdão será lavrado dentro de três dias, salvo motivo de força maior.

Art. 38. As sentenças proferidas pelo Conselho Supremo de Justiça Militar, como tribunal de segunda instância, não são suscetíveis do embargos.

Art. 39. A apelação do Ministério Público devolve o pleno conhecimento do feito ao Conselho Supremo de Justiça Militar, que poderá reconhecer agravantes, embora não alegados.

Art. 40. O recurso de embargos nos processos originários seguirá as normas estabelecidas para o de apelação, sem debate oral.

Art. 41. Não haverá recurso de revisão nem de habeas-corpus.

\section{DISPOSIÇÕES GERAIS}

Art. 42. O prazo para a conclusão do inquérito é de cinco dias. Por motivos excepcionais, a autoridade que o instaurou poderá prorrogar esse prazo por mais três dias.

Art. 43. Nos casos de violência praticada contra inferior, para compeli-lo ao cumprimento do dever legal, ou em repulsa à agressão, os autos do inquérito serão remetidos, diretamente, no Conselho Supremo de Justiça Militar, que determinará o arquivamento, se o fato estiver justificado, ou a instauração do processo, em caso contrário.

Art. 44. O militar que tiver de ser fuzilado sairá da prisão, com uniforme comum e sem insígnias, e terá os olhos vendados no momento em que tiver de receber as descargas. As vozes de fogo serão substituídas por sinais.

$\S 1^{\circ} \mathrm{O}$ civil ou assemelhado será executado nas, mesmas condições, devendo sair da prisão decentemente vestido.

$\S 2^{\circ}$ Será permitido ao condenado receber socorros espirituais. 
Art. 45. Da execução da pena de morte lavrar-se-á uma ata circunstanciada que, assinada pelo executor e três testemunhas, será remetida ao comandante-chefe das Forças Expedicionárias, para ser publicada em ordem do dia ou boletim.

Art. 46. O presidente do Conselho Supremo de Justiça Militar designará a auditoria que deverá processar e julgar os crimes praticados por oficiais e praças em serviço, ou adidos, no Quartel-General do Comandante-chefe das Forças Expedicionárias.

Parágrafo único. O Regimento Interno regulará as substituições e licenças dos juízes, membros do Ministério Público e demais serventuários da Justiça.

Art. 47. O Código da Justiça Militar e o Regimento Interno do Supremo Tribunal Militar serão observados, no que não colidir com esta lei.

Art. 48. O Presidente da República nomeará, se necessário, substitutos interinos de auditor, promotor, advogado e escrivão.

Art. 49. O presente decreto-lei entra em vigor na data de sua publicação, observando o disposto no art. $2^{\circ}$, parágrafo único.

Art. 50. Revogam-se as disposições em contrário.

Rio de Janeiro, $1^{\circ}$ de abril de $1944,123^{\circ}$ da independência e $56^{\circ}$ da República.

\section{Getúlio Vargas.}

Eurico G. Dutra.

Henrique A, Guilhem.

Joaquim Pedro Salgado Filho. 


\section{DECRETO-LEI N. 6.509 - DE 18 DE MAIO DE 1944}

\section{Cria, na Reserva de $1^{a}$ Classe do Exército, um Quadro Especial para os Membros da Justiça Militar da Força Expedicionária Brasileira}

O Presidente da República, usando da atribuição que lhe confere o artigo 180 da Constituição,

decreta:

Art. $1^{\circ}$ É criado um Quadro Especial de Oficiais na Reserva de $1^{\text {a }}$ Classe do Exército, para Juizes e Membros do Ministério Público e Escrivães da Justiça Militar, organizada na forma do Decreto-lei n ${ }^{\circ}$ 6.396, de 1 de abril de 1944

Parágrafo único. O Ministro civil do Supremo Tribunal Militar terá o posto de General de Divisão; o Procurador Geral, o de General de Brigada; os Auditores de $2^{\mathrm{a}}$ e $1^{\mathrm{a}}$ entrância, respectivamente, os de Coronel e Tenente-Coronel; os Promotores de $2^{\mathrm{a}} \mathrm{e}$ $1^{\mathrm{a}}$ entrância, respectivamente, os de Major e Capitão; os Advogados de Ofício da $2^{\mathrm{a}}$ entrância e o Secretário, o de $1^{\mathrm{o}}$ Tenente; os Advogados de $1^{\mathrm{a}}$ entrância e os Escrivães, o de $2^{\circ}$ Tenente.

Art. $2^{\circ}$ O Plano de Uniformes dos oficiais de que trata o presente Decreto-lei será aprovado por ato do Ministro da Guerra.

Art. $3^{\circ} \mathrm{O}$ presente Decreto-lei entrará em vigor na data da sua publicação, revogadas as disposições em contrário.

Rio de Janeiro, 18 de maio de 1944, $123^{\circ}$ da Independência e $56^{\circ}$ da República. (D.O. de 20-5-1944).

\section{GETULIO VARGAS.}

Eurico G. Dutra. 


\section{DECRETO-LEI Nº 6.678 - DE 13 DE JULHO DE 1944}

\section{Altera um dispositivo do Decreto-lei $n^{\circ} 6.509$, de 18 de maio de 1944}

O Presidente da República, usando da atribuição que lhe confere o artigo 180 da Constituição,

\section{decreta:}

Art. $1^{\circ}$ Fica alterado do seguinte modo o art. $1^{\circ}$ do Decreto-lei número 6.509, de 18 de maio de 1944:

"E' criado um Quadro Especial de Oficiais na Reserva de $2^{a}$ Classe do Exército, para Juizes e Membros do Ministério Público e Escrivães da Justiça Militar, organizado na forma do Decreto-lei no 6.396, de 1 de abril de 1944".

Art. $2^{\circ} \mathrm{O}$ presente Decreto-lei entra em vigor na data da publicação do Decreto-lei $\mathrm{n}^{\circ}$ 6.509, de 18 de maio de 1944, revogadas as disposições em contrário.

Rio de Janeiro, 13 de julho de 1944, $123^{\circ}$ da Independência e $56^{\circ}$ da República.

\section{Getulio Vargas.}

Eurico G. Dutra. 


\section{DECRETO-LEI No 7.057 - DE 20 DE NOVEMBRO DE 1944}

\section{Altera o Decreto-lei n. 6.396 que organiza e regula o funcionamento da Justiça junto as Forças Expedicionárias}

O Presidente da República, considerando que as condições especiais que revestem atualmente as operações em que estão sendo empenhadas as Forças Expedicionárias Brasileiras, não exigem o acompanhamento das tropas pelos tribunais de segunda instância e usando das atribuições que lhe confere o art. 180 da Constituição,

\section{decreta:}

Art. $1^{\circ}$ O Conselho Supremo de Justiça Militar, de que trata o Decreto-lei n. 6.396 de 1 de abril de 1944, passa a ter sua sede na Capital da República, ou onde for designado pelo Governo.

Art. $2^{\circ}$ Os artigos $8^{\circ}$ e $9^{\circ}$ do Decreto-lei n. ${ }^{\circ} 6.396$ citado passam a vigorar com a seguinte redação:

Art. $8^{\circ}$ Ao Auditor compete:

I - presidir a instrução criminal dos processos em que forem réus praças, civis, ou oficiais até o posto de coronel, inclusive.

II - julgar as praças e os civis.

Art. $9^{\circ}$ Ao Conselho de Justiça compete:

I - o julgamento dos oficiais até o posto de coronel, inclusive.

II - decidir, sobre o arquivamento dos autos do inquérito, se o fato estiver justificado, ou sobre a instauração do processo, na hipótese contrária, nos casos de violência praticada contra inferior para compeli-lo ao cumprimento do dever legal, ou em repulsa a agressão".

Art. $3^{\circ} \mathrm{O}$ presente Decreto-lei entrará em vigor na data da sua publicação, revogadas todas as disposições que, implícita ou explicitamente, colidirem com o que determina.

Rio de Janeiro, 20 de novembro de 1944, $123^{\circ}$ da Independência e 56º da República.

\section{Getulio Vargas.}

Henrique A. Guilhem.

Eurico G. Dutra.

Joaquim Pedro Salgado Filho. 


\section{VII}

\section{DECRETO Nº 20.082 - DE 03 DE DEZEMBRO DE 1945}

Concede indulto a oficiais, praças e civis, que fizeram parte integrante da F.E.B., ou a ela prestaram serviços, quando em operações na Itália, já condenados ou não, cujos crimes não são de natureza infamante.

O Presidente da República, usando da atribuição que lhe confere o artigo 75, letra f, da Constituição Federal,

\section{decreta:}

Art. $1^{\circ}$ Fica concedido indulto aos oficiais e praças que, como parte integrante da F.E.B., na Itália, hajam cometido crimes que não os de homicídio ou de deserção para o inimigo, tenham sido ou não julgados e condenados.

Art. $2^{\circ}$ Fica comutada, de dez anos e três meses, de reclusão e dois meses e vinte e seis dias de detenção para cinco anos, um mês e quinze dias de reclusão e um mês e treze dias de detenção a pena a que foi condenado por homicídio doloso e lesões corporais, o cabo Rômulo Testa e de oito anos e oito meses de reclusão para quatro anos e quatro meses de reclusão a pena a que foi condenado o soldado Domingos Cabral, ambos condenados por crimes praticados na Itália, quando a serviço da F.E.B.

Art. $3^{\circ}$ Fica concedido indulto aos civis de nacionalidade italiana Di Bartolomeu Ader e Ranzzete Soliere, empregados do Serviço de Intendência da F.E.B, na Itália e do Posto Regulador de Livorno, condenados pela Justiça da F.E.B., como incursos respectivamente nos arts. $198, \S 4^{\circ}, \mathrm{V}$, e art. $181, \S 3^{\circ}$ e $182, \S 5^{\circ}$, combinado com os artigos $66, \S 1^{\circ}$, e 314 , tudo do C.P.M.

Rio de Janeiro, 03 de dezembro de $1945,124^{\circ}$ da Independência e $57^{\circ}$ da República. (D.O. de 8-12.945)

\section{José Linhares.}

Canrobert P. da Costa.

A. De Sampaio Doria 


\section{VIII}

\section{DECRETO-LEI No 8.443 - DE 26 DE DEZEMBRO DE 1945}

\section{Extingue os órgãos da Justiça Militar organizada pelo Decreto-lei n. 6.396, de 1 de abril de 1944 e dá outras providências}

O Presidente da República, usando da atribuição que lhe confere o artigo 180 da Constituição e

Considerando que, com o regresso da Força Expedicionária Brasileira, não é mais necessário que continue funcionando a Justiça Militar que foi organizada para acompanhala em operações de guerra,

\section{decreta:}

Art. $1^{\circ}$ Ficam extintos os órgãos da Justiça Militar organizada pelo Decreto-lei n. 6.396, de $1^{\circ}$ de abril de 1944, passando suas atribuições a ser exercidas, em primeira instância, pelas Auditorias da $1^{a}$ Região Militar e, em seguida, pelo Supremo Tribunal Militar, na forma do mesmo diploma.

Parágrafo único. A distribuição dos processos e o julgamento da apelação, no referido Tribunal, reger-se-ão pelas normas estabelecidas em seu Regimento Interno.

Art. $2^{\circ} \mathrm{O}$ inquérito ou documentos relativos ao crime, assim como os processos em andamento, serão remetidos ao auditor da $1^{\text {a }}$ Auditoria da $1^{\mathrm{a}}$ Região Militar, que os distribuirá de conformidade com o art. 90 do Código da Justiça Militar.

Art. $3^{\circ}$ A composição do Conselho de Justiça de que trata o art. $6^{\circ}$ do Decreto-Lei $n$. 6.396, na parte referente aos juízes militares, será feita mediante sorteio nos termos do artigo 12 do Código da Justiça Militar.

Art. $4^{\circ}$ Compete ao Auditor da $1^{\text {a }}$ Auditoria da $1^{\text {a }}$ Região Militar executar as sentenças proferidas antes da vigência deste Decreto-lei, inclusive as que dependam de recurso.

Art. $5^{\circ}$ Os autos dos processos findos e os livros e documentos da Secretaria do Conselho Supremo serão arquivados no Supremo Tribunal Militar.

Art. $6^{\circ} \mathrm{O}$ pessoal da Justiça Militar Especial deve voltar às suas primitivas funções, providenciando o Ministério da Guerra a desconvocação respectiva.

Art. $7^{\circ}$ Fica estipulado o prazo de 30 dias a contar da data da publicação do presente Decreto-Lei para que o Conselho Supremo de Justiça Militar da Força Expedicionária Brasileira e as respectivas Auditorias encerrem seus trabalhos e apresentem os respectivos relatórios.

Art. $8^{\circ} \mathrm{O}$ presente Decreto-Lei entrará em vigor da data de sua publicação, revogadas as disposições em contrário.

Rio de Janeiro, 26 de dezembro de 1945, 124º da Independência e 57º da República.

\section{José Linhares.}

Canrobert Pereira da Costa 
IX $^{321}$

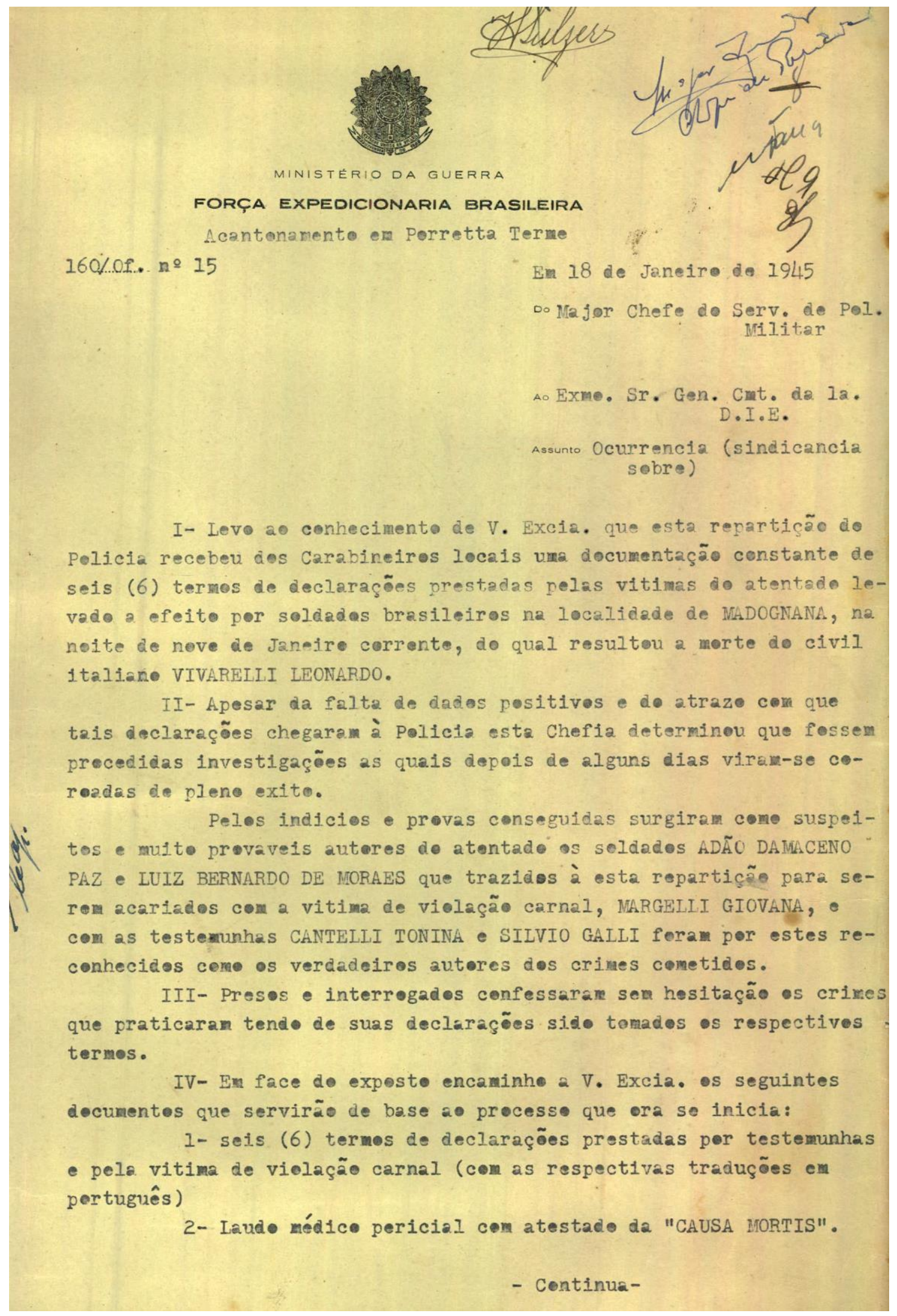

${ }^{321}$ Os anexos IX ao XXI abaixo apresentados foram obtidos dos Autos da Apelação n ${ }^{\circ} 21-1945$, cuja cópia do arquivo em pdf foi gentilmente cedida pelo Setor de Arquivos Históricos do Supremo Tribunal Militar (“STM”) em Brasília/DF. 


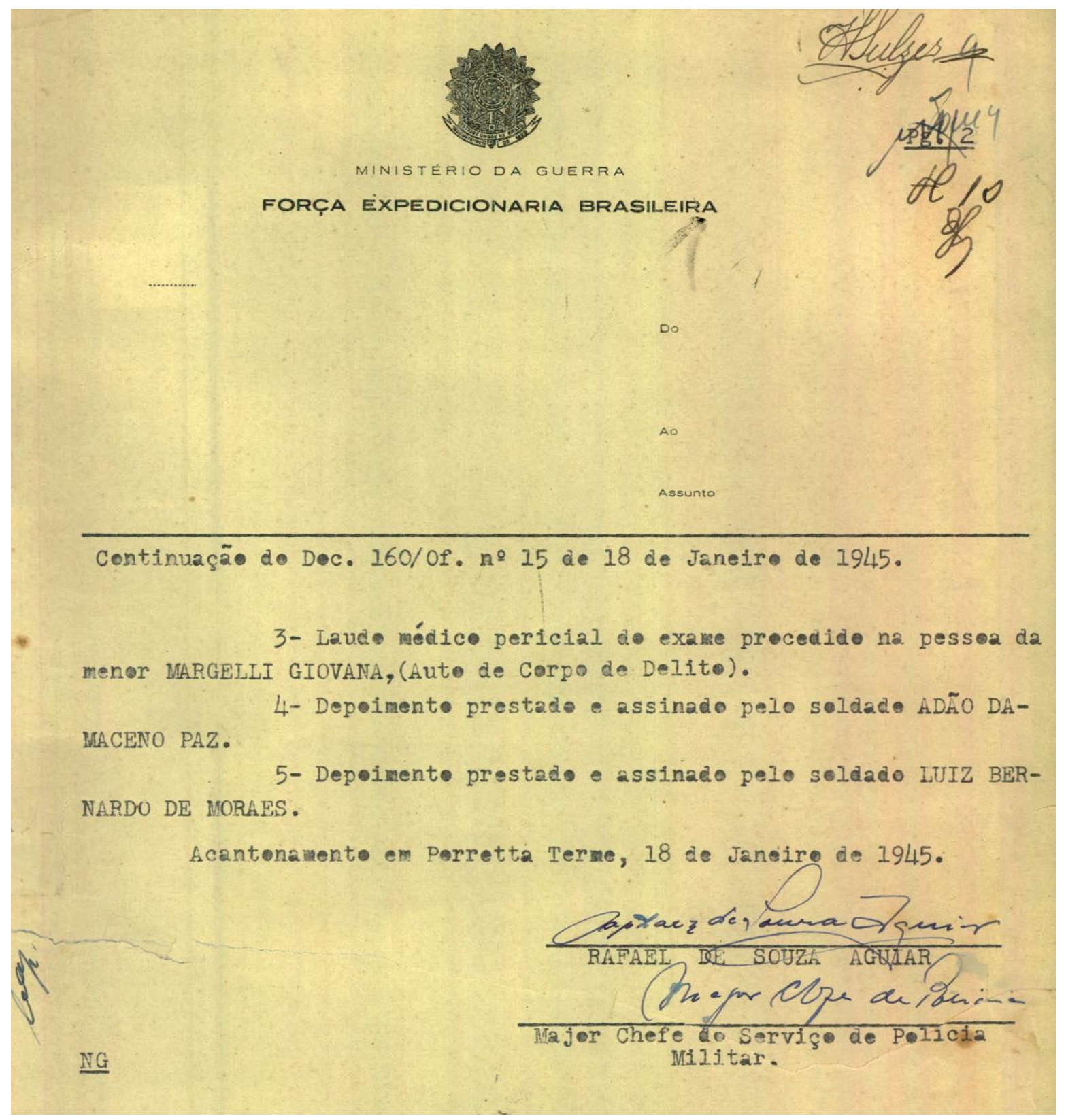




\section{X}

\section{IAUDO MEDICO PIRT I AI}

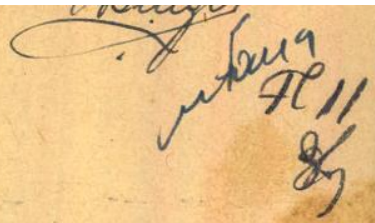

As 16,30 horas do dia de hoje, compareci ao local denominado Iladognana, em frente \& residencia ne 231, e em presença do soldado Pedro Augusto Teikeira, do Pelota de policia Nilitar da la. Divis a de Infantaria Expedicionéria, examinei o cadever de VIVARIII IEONARDO, IV. GIUSEPPS, italiano, com 57 anos de idade, de cor branca, que se achava prostrado em decubito dorsal sobre os degraus da entrada da referida resilencia, havendo so b ele e na cavidade bucal grande quentidade de sangue,

CONSTATI um ferimento penetrante do to rax com o orificio de entrada de cerca de 1 centimetro de diametro a nivel da regiao supra clavicular esquerda, na base do pescoço cujos grandes vasos foram Iesados. Apresentava ainda contusres na regiro ocipital e na regiro dor sal do torax, que deixaram a impressao de terem sido produzidos pela queda.

t.

o ferimento acima referido, tem 0 aspecto de $I$ esa por projetil de ama de fogo.

Nenhuma outra I esro foi constatada.

* "CAUSA moRrIS". Ferimento por projetil de ama de fogo pene trante do torax, com lesto dos vasos do pescoço. Anemia aguda.

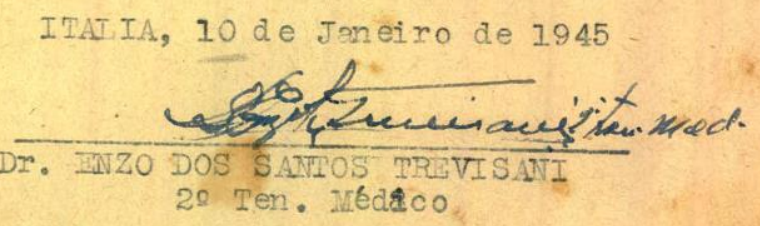




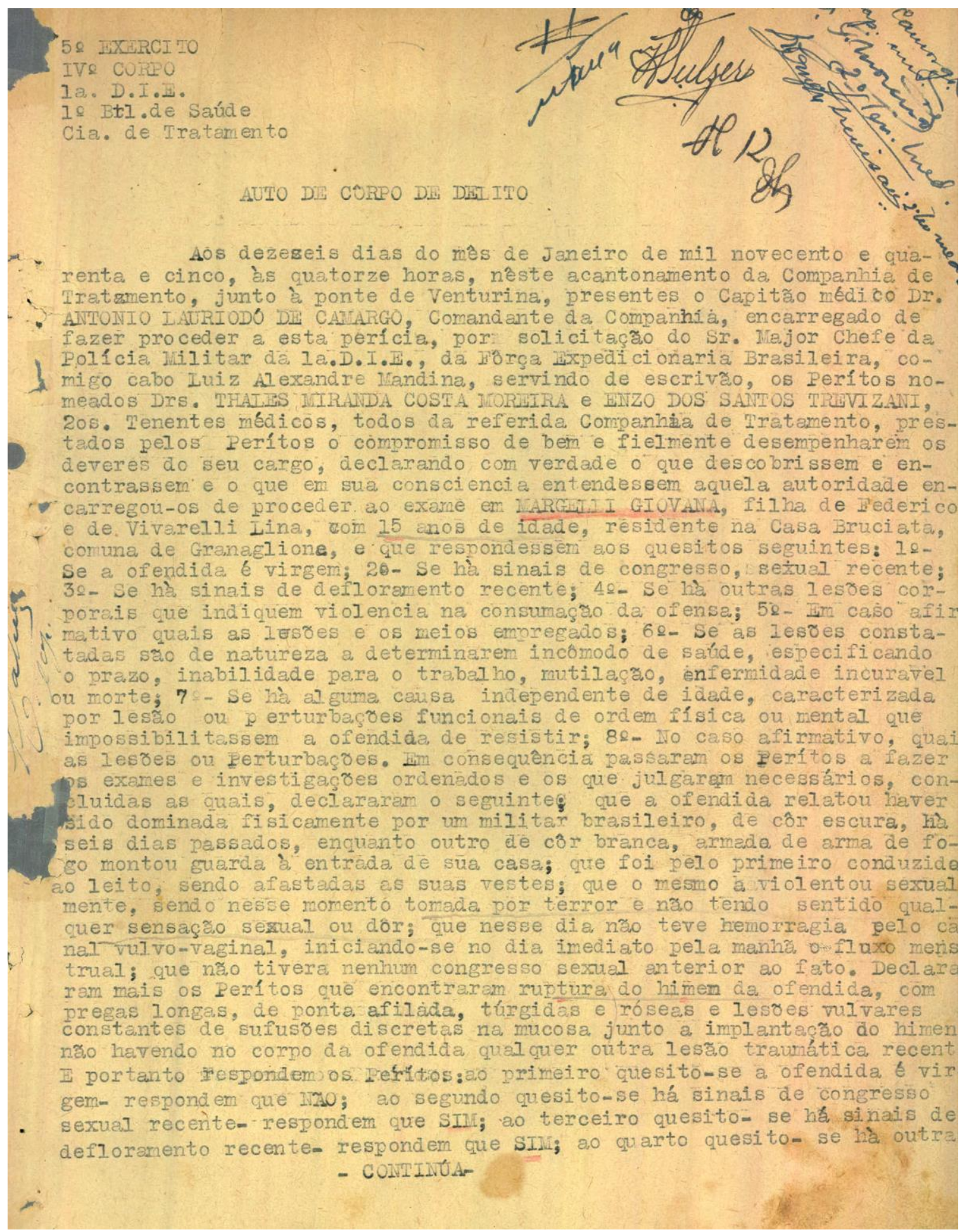


204

outras lesres corporais que indigu-

sa- respondem que $\mathrm{AO} ;$ ao quinto quesitoto- prejucicado; a, sétimo quesito- se hà gI guma causa independente de idade caracterizada por lesa ou perturbaçres funcionais de ordem flisica ou mentaI, que impossibilitassem a ofendida de resitir - respondem que NAO; aO oitavo quesito-prejudicado; e form estas as declaraçres que em sua consciência e deboixo do compromisso prestado fizeram. por nada mais haver deu-se por concluido o exame ordenado e de tudo se Iavrou o presente auto, que vai assinado e rubricado pela autoridade encarregada de fazer proceder a esta perícia, que presidiu a diligência comigo esorivăo que o escreví, pelos perítos e as testemunhaí cabo ARY BARRTIO SIQUETRA e o soldado DANIIO DI ANDRADH, que se achavam presentes: du fouiz Clesamoke C/audiba, servindo de escrivao o

$\int_{1}^{2}$

- th tric $>$

S. Shales hivanda torta hining $20 \mathrm{ten}$. Ined.

Conght hunsais riturned.

edor Ary barreto Siguins

avldadc. Dacilotudiads

babo Luiz Alxanche Maushisea 
XII

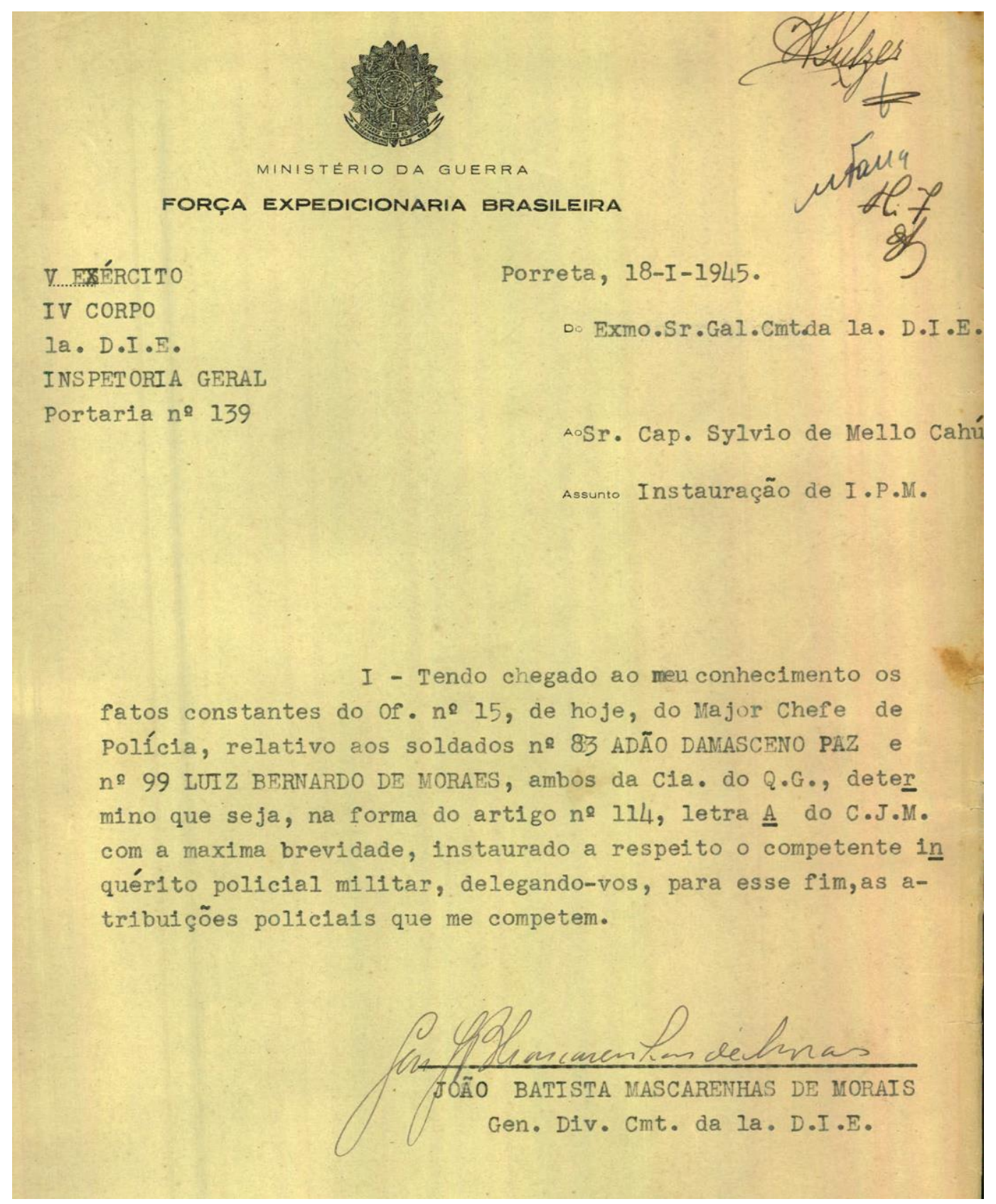


XIII

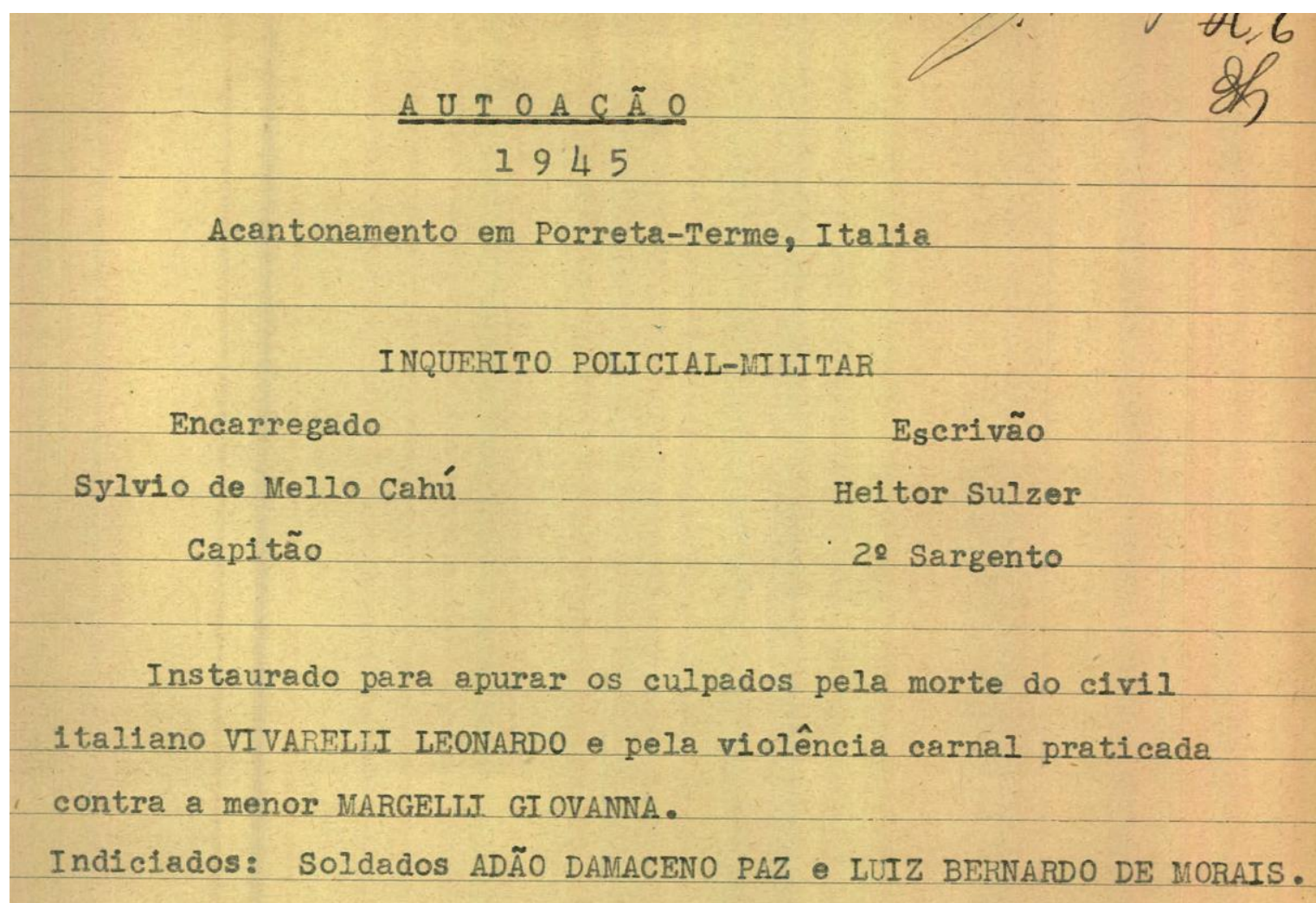

\section{$A U T O A C \tilde{A} O$}

Aos 18 dias do mês de Jañeiro do no de 1945 (mil novecentos e quarenta e cinco), nesta cidade de porreta-Merme, Italia, no acantonamento do Quartel General Avançado, autuo a portarla e mais documentos que se seguem os quais foram entregues a mim pelo encarregado do presente inquer1to; do que, para constar, lavro o presente termo.

EU 20 Sargento Heitgr Sulfer, servindo de escrivão, datilografel e subscrevo. cucuriat?

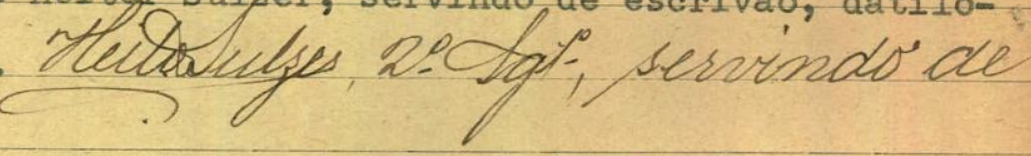




\section{XIV}

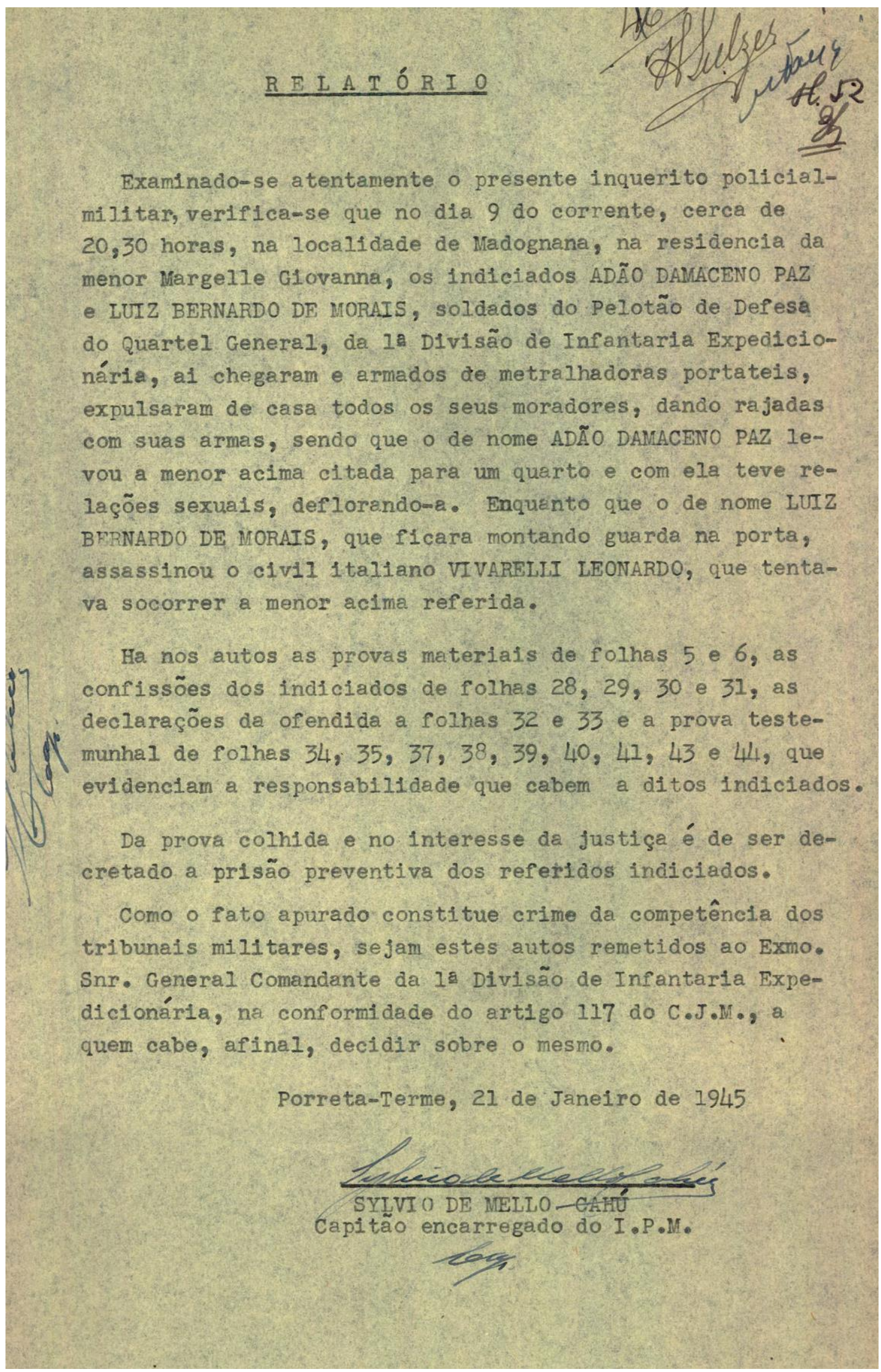


XV

\section{CERTIDÃO}

Certifico que em cumprimento ao despacho de fls. 53 v. e 54, foi providenciado o seguinte: a) em ofício $\mathrm{n}-38$, de hoje, foi comunicado o recebimento da denúncia ao Comando da Divisão; e b), em ofício nㅇ 39, tambem de hoje, foi comunicado ao Major Chefe da Policia Militar, o recebimento da denúncia; solicitada a renessa do extrato dos assentamentos dos acusados; solicitadas providências para que a audiência de instrução criminal seja realizada na séda daquela Chefia, no dia designado, isto é, a primeiro de fevereiro próximo; e finalmente, remetendo o Mandado de Prisão dos acusados, por ter sido decretada a prisão preventiva dos mesmos. Do que, para constar, faco este termo. Pistoia, Itália, 26 de janeiro de 1945.

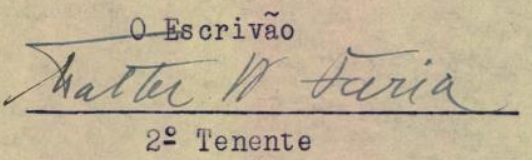

\section{CERTIDÃO}

Certifico que nesta data expedi o Mandado de Citação dos Acusados, afim de virem ver-se processar, no dia 1 - de fevereiro próximo, às 10 horas, na séde da Chafia da Polísia Militar, em Porreta-Itália. Do que, na a constar, lavrei este termo. Pistoia, Itália, 27 de janeiro de 1945.

O Escrivão

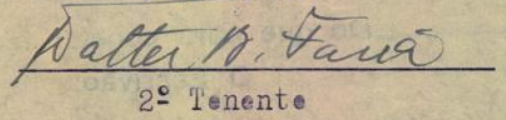




\section{XVI}

\section{AUTO DE INTERROGATÓRIO}

Ads orimeiro dias do mês de fevereino de mil novecentos e quarenta e cinco , em Porreta-Terme, Itália, na Chefia do Servi-

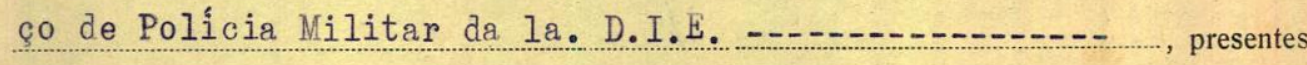
o representante do Ministério Público, o doutor..rlando Moutinho R. Costa e 0 réu foi êste interrogado pelo...Ten.Cel. Auditor do modo que se segue: Perguntado qual o seu nome, naturalidade, idade, filiação, estado e residência? Respondeu chamar-se Ad̃̃o Damaceno Paz ser natural d.. Rio Grande do Sul ter vinte seis anos de idade, ser filho de Jos̃o Medina Dama cono Paz

e de Izaura Damaceno Paz ser.soltai4. e residir no seu quartal do Pelotão de Policia

Qual o seu pôsto emprego ou profissão? Respondeu ser...... soldado da Cia. do Q.G.

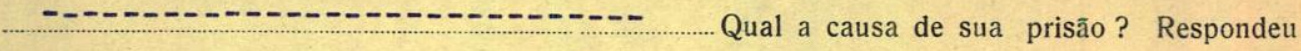
que se acha preso em consequencia do processo

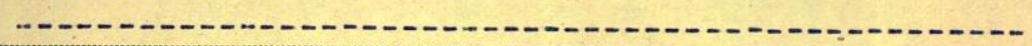
Onde estava ao tempo em que se diz ter sido cometido o crime? Respondeu que em Nadoniana, Itália $\mathrm{Si}$ conhece as pessôas que depuzeram no processo desde quando, e, no caso de revelia, si tem alguma cousa a opôr contra elas? Respondeu que disse que não conhece apenas Galli Sylvio e Cantelli Stefano, não se lembrando de tê--los visto, nada tendo a opôr contra elas.

Si tem algum motivo particular a que atribua a acusação? Respondeu que não.

O que tem a dizer sôbre a imputação que the é feita e si tem fatos a alegar ou provas que justifiquem ou mostrem a sua inocencia? Respondeu que t.m e.s.eu...Advogado dirá oporrumante. E, nada mais disse nem lhe foi nerguntedo, dando-se por findo opresente auto de interrogatorio, que depois de 1 ido e achado conforme, vai assinado pelo Ten. Cel. Aditor e pelo Acusa- 


\section{AUTO DE INTERROGATÓRIO}

Aos orimeiro

dias do mês de fevereiro

de mil novecentos e

quarenta e cinco , em Porreta-Terme, Itália, na Chefia do Servigo de Policia Militar da la. D.I.E. - - . - . - . - .... o representante do Ministério Público, o doutor Or lando Moutinho R. Costa e o

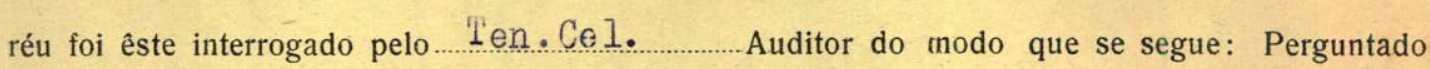
qual o seu nome, naturalidade, idade, filiaçāo, estado e residência? Respondeu chamar-se Luiz Bornardo do Norais ser natural do Estado do Rio Grande do Sul ter vinte e um anos de idade, ser filho de Lino Bernardo Dutra e de D.... Maria Candida de Morais ser soltairo e residir no seu quartel do Pelotão de Polícia

Qual o seu pôsto emprego ou profissão? Respondeu ser soldado da Cia.do Q.G. - - - - -

Qual a causa de sua prisão? Respondeu que se acha preso em consequência do processo

Onde estava

ao tempo em que se diz ter sido cometido o crime? Respondeu que em Madoniana, Itá $1 i_{2}$ $\mathrm{Si}$ conhece as pessôas que depuzeram no processo desde quando, e, no caso de revelia, si tem alguma cousa a opôr contra elas? Respondeu que...não conhece anenas Galli Sylvio e Cantelli Stefano, não se lembrando de tê-los visto, que nada tem a opor con. tra as testemunhas.

Si tem algum motivo particular a que atribua a acusação? Respondeu que não tem.

O que tem a dizer sôbre a imputação que the é feita e si tem fatos a alegar ou provas que justifiquem ou mostrem a sua inocencia? Respondeu que tem e que seu Advogado dirá oportunamente. E, nada mais disse nem the foi perguntado, dandose por findo o presente auto de interrogatorio, que denois de lido e achado conforme, vai ass inado pelo Tenente Coronel Audi- 


\section{XVII}

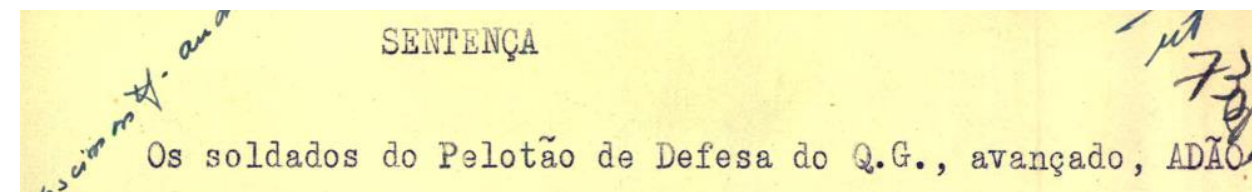
DAMACENO PAZ e LUIZ BERNARDO DE MORAIS, foram denunciados como incursos na sanção do art. 312, §único, letra b- com binado com o art. 192, e do art. 302, III, combinado com o artigo 181, §2, V, tudo do C.P.M., sob a a.cusação de, na noite de 9 de janeiro de 1945, cêrca das 20 horas, em Madognana, Comune de Granaglione, Itália, - haverem, mediante ameaça, forçado MARGELII GIOVANNA, virgem com 15 anos de idade, a ter com êles conjunção carnal, - e de haverem, para assegurar a execução desse delito, morto, a tiros de metralhadora, o tio daquela menor, VIVARELLI LEONARDO, quan do êste pretendia entrar na casa em que estava hospedado,e onde os Indigitados the violentavam a citada sobrinha.

0 processo obedeceu a todas as formalidades legais, ten do sido inquiridas as seis testemunhas arroladas na denúncia, sendo treis numerárias, e treis informantes.

Provando a morte de Vivarelli Leonardo em consequência do ferimento produzido com bala que the lesou na base do pescoço os grandes vasos, há o laudo médico à fls. 10, - e provando o defloramento de Margelli Giovanna, tem-se o auto de corpo de delito a fls. 11.

- Através das provas colhidas no inquérito e no sumário, com as declaracões da Ofencida, Giovanna, a fls. 23, 24,37 e 64, com os depoimentos das testemunhas CANTELII TONINA a fls. 16, 17, 39 e 65, CANTELLI STEFANO a fls. 18, 19, 21, 42 e 66, e GALII SILVIO a fls. 45 e 66 v., e com a confissão dos dois Acusados, DAMASCENO a fls. 13 e 33, e BERNARDo a fls. 14 e 35, - confissão esta que foi testemunhada pelo 3 Sargento VITÓRIO MANGANELII, fls. 34,36 e 67 , e 
pelo cabo RENAN ALVES PINHEIRO, fls. 34,36 e $67 \mathrm{v},,-$ pod se reconstituir os fatos, ora jub-judice, como ocorridos da seguinte forma: -

A vitima, GIOVANNA, - que residia na localidade próxi ma, denominada "Casa. Bruciata", e que se encontrava há uns cinco dias em Madognana, visitando e prestando assistência. a sua avó, doente, - foi vista pelos 2 Denunciados, cêrca das 16 horas, quando passeva pela rua em companhia de MED $\underline{O}$ IA VITTORIA, moça esta que foi ouvida no inquérito a fls. 26 e 27.

Entenderam os dois Acusados de seguir, como seguiram, as duas jovens, e, venco-as entrar na casa em que GIOVAIVNA estava hospedada, ali também entraram êles, movidos eviden temente por sentimentos que não podiam ser castos.

Mas, deparando-se naquela residência com D. MARIA RITA e com D. TONINA CANTELII, respectivamente avó e prima de GIOVANNA, e com um menino de 3 anos de idade, FERDINANDo, filho de D. Tonina, os Indigitados se limitaram em agradar aquela criança, oferecendo- Ihe um pedaço de chocola te, e em dirigir algumas palavras aos presentes, dizendoIhes que não tivessem mêdo, pois os brasileiros eram bons, - e, depois de terem se manisfetado mal impressionados com a educação de GIOVANNA, que naturalmente se mostrava retraída, saíram, declarando que iam entrar de serviço.

Chegados a. Q.G., jantaram, armaram-se, cada um com uma metralhadora portátil, e voltaram os dois Denunciados àquela casa, encontrando alí, já cêrca das 20 horas, senta dos junto da estufa, aquecendo-se, além de GIOVANNA, de D. Maria Rita, de D. Tonina e de seu filhinho Ferdinando, os 
menores Stefano Cantelli e Giuseppe Vivarelli (fls. 30 31), ambos primos da ofendida, com 20 e 14 anos de idade, respectivamente.

Apenas Damasceno, aceitando o convite que então lhes foi feito, sentou-se, preferindo seu companheiro, Bernardo, ficar en pé, apoiando sua metralhadora sobre o espaldar da cadeira que the havia sido oferecida.

$\wedge$ En dado momento, como pondo em execução o plano ajustado entre os dois, BERNARDO, a rajadas de sua arma, apagou a luz, passando a ameaçar os presentes, estabelecendo entre êles o pânico, fazendo-os fugir uns pela porta, outros pela janela, sendo que alguns se abrigaram nas demais dependências da casa, - $a$ mesmo tempo que DAMSENO se ati rava à Giovanna, subjugando-a e levando-a, como a levou,para um quarto.

E, enquanto DAMACENO alí forçava, como forçou, a moça a ter com êle conjunção carnal, - BERNARDO, afim de evitar que a Vítima pudesse receber socorro, se manteve de guarda na porta da casa com tal disposição que não trepidou em atirar sobre LEONARDO VIVARELLI, matando-o, quando este tio da Ofendida, regressando de uma visita que fôra fazer, ali entrava, provavelmente até sem saber do que se passava, e do perigo que o esperava.

Praticado este homicidio, Bernardo gritou para seu com panheiro que "acabasse ligeiro", pois já havia morto um ho$\underline{\text { mem }}$ (fls. 14 e 36).

Apezar de ter recebido esta noticia, e de ouvir as demais descargas de metralhadora que Bernardo continuou a dar (fls. 13 e 34), DAMACENON, não só persistiu e conseguiu con- 
seguiu consumar o ato sexual que iniciára, como, em segui-) da, afim de que Bernardo também pudesse se servir da moça, foi, por sua vez, colocar-se na porta, montando guarda, atirando sempre que ouvia barulho ou temia que alguem estivesse se aproximando.

Bernardo, porém, embora tenha passado no quarto com a Vítima cêrca de meia hora, se sentiu impotente para realizar a conjunção carnal, atribuindo essa sua incapacidade ao estado de èmbriaguês em que se encontrava.

Todavia, ao seu companheiro, naturalmente por amôr próprio, Bernardo se apresentou declarando que também consumára o ato.

Fugiram em seguida os dois Denunciados, tendo Bernardo perdido na estrada a sua lanterna e o seu cachinê, - ob jetos esses que, na manhã do dia seguinte, foram encontra dos e aprésentados às autoridades por ITALO VIVARELII ( $f l s$. 28 e 48), irmão do morto, quando, em companhia de seu sobrinho Stefano Cantelli, foi queixar-se, pedindo providências.

Como já se assinalou, os próprios Acusados confessa ram sua ação delituosa na forma que se acaba de expôr, e que coincide com os depoimentos da Ofendida e das testemunhas nos fatos que assistiram, ou em que se viram envolvi das.

Resta consignar que também Damaceno diz ter agido em estado de embriaguês.

Mas, embora embriagados, os dois Indigitados tanto ti veram e mantiveram plena capacidade de entender o caráter criminoso dos atos cometidos, que, na manhã do dia seguinte, se deram ao cuidado imediáto de limpar suas armas ( $f l s$. 34 e 36$)$. 
Em seus antecedentes a $\mathrm{fls} .60$ e 61 , verifica-se que ambos já haviam sofrido repressão disciplinar, não só por outras transgressões, como por abuso de alcool.

Durante os debates orais para julgamento, o Dr. Promotor, sustentando que se achava provada a imputação feita na denúncia; que não eram bons os antecedentes dos Acu sados, e que havia contra êles as agravantes das letras $\underline{h}$, $\underline{I}$ e $\underline{n}, \mathrm{n}=$ II, do art. 59 , pediu a condenação dos Indiciados à pena máxima.

Contestando a acusação, o Dr. Advogado argunentou que 0 느 Denunciado não praticou o crime de violência uma vez que nẽo houve resistência por parte da vítima, e que - 2ํㅡㄹ Denciado não agira dolosamente e sim cuilposamente quando atirou contra Leonardo Vivarelli, pelo que pediu a absolvição daquele Acusado.

Isto posto, e

CONSIDERANDO que, nos termos do art. 33 do C.P.M., quem concorre, de qualquer modo, para o crime, incide nas penas a êste cominadas

CONSIDERANDO que, consoante a definição do art. 23, I, do mesmo Código, age dolosamente quem quer o resultado ou assume o risco de produzi-io;

CONSIDERANDO que, em face desses principios, se torna irretorquivel a co-autoria dos dois Denunciados quer no delito de violência carnal, seja no dethomicídio,pois, não só êste foi cometido vizando assegurar a execução daquele, como evidente é, pelo próprio desenroler dos fatos, que os Acusados haviam ajustado que se revezariam na prática do ato sexual, pactuando mais êles que um ficaria de 
guarda, à mão armada, para impedir, a quialquer custo, que a.Iguem se aproximasse, enquanto o outro satisfizesse seu desejo sexual;

CONSIDERANDO que tanto havia sido essa a deliberação de ambos, que, mesmo depois de avisado que seu companhe if

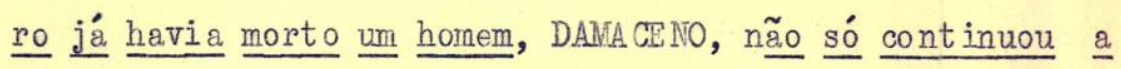

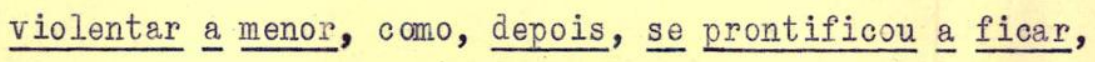
como ficou, de guarda, também atirando com sua metralhadora, sempre que ouvia rumor, afim de que Bernardo, por sua vez, pudesse ter relação sexual com a me sma menor;

CONSIDERANDO que, atendendo aos antecejdentes e a per sonalidade dos agentes, è intensidade do dolo, aos motivos, às circunstâncias e consequências dos crimes, ora sub-judice, os Indigitados revelaram acentuada periculos $\underline{i}$ dade, podendo-se, nestas condições, estabelecer-lhes por pena base grau não inferior ao médio;

CONSIDERANDO que, longe de haver qualquer circunstân cia que pudesse atenuar essa penalidade, há contra os In diciados as agravantes de terem cometido os delitos em estado de embriaguês, com emprego de armas de servico procuradas para aquele fim, e em país estrangeiro, ex-vi do art. 59, II, letras $\underline{c}, \underline{b}$ e $\underline{n}$, do C.P.M.

CONSIDERANDO que esses fatos, segundo informa o oficio a fls. 58, foram praticados em zona de efetivas ope $\underline{\text { rações militares, }}$ e, assim, nos termos do art. 318 do têx to legal, devem ser tidos como cometicos em presença do inimigo, exigindo assim a repressão enérgica da Justiça, não só para manutenção da Ordem e da Disciplina, como pa- 
ra resguardar o respeito e a confiança que deve inspirar o nosso Exército entre as fôrças aliadas e a população com que entramos em contato,

RESOLVO condenar, como condeno, os soldados ADĨO DAVA CENO PAZ e IUIZ BERNARDO DE MORAIS à pena máxima do artigo 302 , III, combinado com o artigo 181, \$2ㅇ, V, do C.P.M., a qual, sendo a de morte, pelo homicídio cometido para assegurar a execução de violência carnal, absorve a pena de corrente da prática deste delito, uma vez que dêle não resultou o falecimento do agente passivo.

$$
\text { P.R.I. }
$$

Acantonamento em Pistoia, 7 de fevereiro de 1945.-

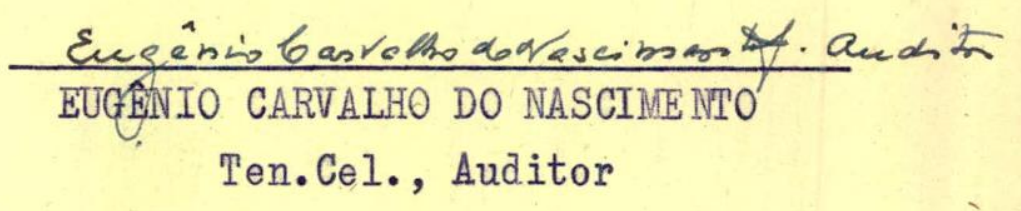




\section{XVIII}

EGREGGIO CONSELHO SUPREMO DE JUSTIÇA MILITAR

A resneitavel sentença de fls. condenou os soldados ADÃO DAMASCENO PAZ e LUIZ BERNARDO DE MORAIS, ¿̀ po na máxima do artigo 302, III, combinado com o artigo '181, $\$ 2$, V, do Código Penal Militar, "pelo homicídio cometi do para assegurar a execução da violência carnal".

A participação dos soldados ADÃO e BERNARDO nos fatos de que resultou o presente processo é inteiramente diversa, sendo as ações de ambos perfeitrmente indepen dentes, meșmo quanto aos resultados oriundos.

ADR̃O DAMASCENO PAZ, praticando a conjução carnal com Marcelle Giovanna, som que o ato se tenha revestido das caracteristicas da violência, não pode absolutamente ser responsabilizado pelos tiros que a embriaguệs de seu companhe i ro disparou.

Os depoimentos dos soldados ADR̃O e BERNARDO, re conhecidos pela douta sentença como confissão plena da culpabilidade de ambos, não podem ser invocados como pro Va de acôrdo preestabelecido, para a execução dos crimes de que são imputados.

A regra do artigo 18 do Código Penal Militar,

$$
\begin{aligned}
& \text { "O resultado de que depende a } \\
& \text { existência do crime somente : } \\
& \text { imputavel a quem lhe deu cau } \\
& \text { sa" }
\end{aligned}
$$

deixa claro a não responsabilidade do soldado ADÃO na morte de Vivarelli Leonardo.

No momento dos disparos causadores da morte do 
referido italiano, o soldado ADÃO se encontrava no quarto com Marcelle, não podendo, portanto, ser responsavel pela imprudência de seu companheiro.

A declaração da "vítima" (fls. 23), não con vence quanto ì violência.

E, se la no depoimento de fls, 64, diz ter sido subjugada, o tempo decorrido entre as duas decla rações, pode ter influido numa falsidade, cousa lógice de se admitir pelo interesse que tem na punição do companheiro do causador da morte de seu tio.

$$
\mathrm{x} \quad \mathrm{x} \quad \mathrm{x}
$$

A respeitavel sentença aceitou a classificação do delito no artigo 302, III, apoiando-se para tanto, na informação da Chefia de Polícia da Divisão e, considerando como"presença do inimigo", a "zona de efetivas operações militares" onde se passaram os fatos, deixando, assim, de interpretar devidamente o artigo 318 do Código Penal Militar.

Para que se caracterize a "presença do inimigo" : necessário que se tenha uma "zona de efetivas operações militares" que esteja na iminência ou em situação de hostilidades.

E tanto o:, que o Estatuto Penal Militar diferencia bem as situações, falando no Capitulo XI Do homicidio e das lesões corporais, "em presença do inimigo"; no Capitulo XII - Dos crimes contra o patrimonio, "em zona de operações militares" •, finalmente, no Capítulo XV - Do rapto da violência carnal, "em lugar de efivas hostilidades".

o lugar onde se passaram os fatos determi - 
nantes do caso "sub-judice", ' zona de fetivas operações militares, como tambem : toda a zona de operações dos exércitos aliados na Itália.

Daí concluir que toda zona de operações militares, forçosamente tem que se encontrar "na iminência ở em situação de hostilidades", é fugir a verdadeira interpretação do texto logal. -EGRÉGIO CONSELHO:

O meretissímo julgador não aplicou devidamente 2 lei, condenando à pena de MORTE os soldados ADR̃O BER NARDO.

Responsabilidades diversas têm os mesmos e, ainda admitindo a co-autoria, a sentença apelada não poderia condena-los à pena do artigo 302, III, por não ter sido o crime praticado "em presença do inimigo".

A vista do exposto, pedem e esperam os apelantes, seja reformada a sentença, fazendo assim, êsse EGRÉGIO CON SELHO, mais uma vez, a merecida

$$
\text { J U S T I Q A. }
$$

Pistoia, 8 de fevereiro de 1.945

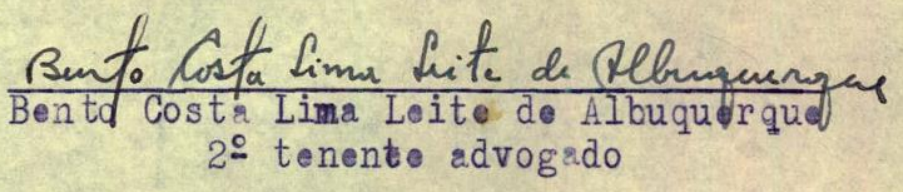


221

XIX

VISTA

Aงs. dias de loverevi do mil novecentos e quareuta e eni faço estes autos com vista pelo praso legal a․

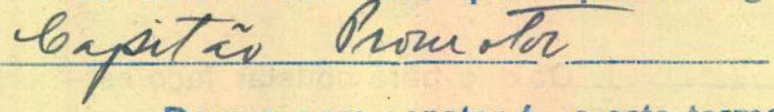
Do que para constar f: ;o este termo.

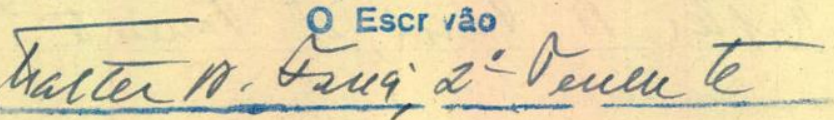

Egregio Conse Iho Supremo.

Evidentemente não tem razão os apelantes. Os crimes praticados pelos acusados estão plenamente provados e a responsabilidade que lhes cabe, perfeitament e apurada.

A co-autoría está exuberantemente demonstrada, quer com as confissões prestadas pelos acusados como pelas demais circunstâncias que se ligam ao caso. Estiveram pela tarde na casa da menor, voltaram ao Quartel Genral e, combinadamente, armados com metralhadoras, voltaram a referida casa para a prática do crime de conjunção carnal. Enquanto o primeiro acusado violentava e deflorava a menor o segundo montava guarda á porta, momento em que matou com uma rajada o velho tio da mesma. Depois torcaram os papeis, indo o primeiro para a porta e o segundo para o guarto.

Como, neste caso tão evidente, contestar a co-autoría :

Os crimas praticados revestiram-se de suma barbaridade, já pela criança deflorada estupidamente sob uma ameaça terrivel estando os acusados armados com motralhadoras e dando rajadas com as mesmas, já pe la morte dolvelho que procurava naturalmente, evitar aquele crime, mas, ante a ameaça retirava-se sem resistência.

Fátos identicos vêm se repetindo, uns atraz dos outros, chegando ao conhecimento da. Justi- 
Justiça e dando mostras que os comandos não têm ff meios para por paradeiro a êles. Nem mesmo a ação discreta dos Capeläes Militares consegue refreiar instintos maus nesses momentos, déixando claro que toda energia é pouca.

A sentença recorrida bem apreciou a prova dos autos e meditadamente aplicou a lei. Assim, sendo negado provimento a apelação interposta pelos acusados, Soldados Adão Damaceno Paz e Luiz Bernardo de Morais, como improcedente, mais uma vez fará esse Egregio Conselho a merecida

$$
\begin{aligned}
& \text { Justiça. } \\
& \text { Pitoia, } 90 \text { e Teveruino ole 1945- } \\
& \text { O.n. Diluino }{ }_{\text {Promi. }} \text { Pata }
\end{aligned}
$$


XX

\section{- PROCURADORIA GERAL -}

PARECER N N $^{\circ}$ -

Os soldados ADÃO DAMAGEHO PAZ $\theta$ LUIZ BERNARDO DE

MORAIS confessaram friamente, com abundâncla de detalhes, os crl mes que praticaram em MADOGNANA, comuna de Granaglione, Itália. Relatam êles que, após o jantar, muniram-se de me tralhadoras portateis, dirigindo-se para a casa onde já haviam estado, $\dot{a}$ tarde, em procura de uma mulher que Ihes "tinha felto cara fela".

Bateram à porta. Os moradoros convidarammos a en trar, e a aquecer-se junto ao fogo. A seguir, DAMACENO disse a BERNARDO que apagasse a luz, "pols querla pegar a moça". Seu com panheiro deu "uma rajada de metralhadora", extinguindo a chama bmuxoleante de uma lamparina a querozene. Enquanto as outras pes sôas fugiam, atemorizadas, DAMACENO conduziu MARGELII GIOVANNA para o quarto, $\theta$, af, saciou os instintos carnais. Para facilltar a execução do delito, por demais revoltante, BERNARDO colocou-ss de guarda, à porta, atirando em VIVARELII LEONARDO, quando êste regressava de uma visita. E, logo depois, gritou : "a pressa-te (Damaceno) que já matel um homem".

Consumado o a to sexual, que o incidente ora descrito, a rápidos traços, nem siquer interrompeu, DAMACENO ficou, tambem, de guarda, para que BERNARDO se servisse, 1gualmente, da desventurada MARGRLII. Não pôde, entretanto, real1zar a cópula, por Impotêncla ocasional, oriunda do estado de embriaguez em que 
se encontrava.

o inquérito fol instaurado em consequêncla de "de clarações prestadas pelas vítimas do atentado", e entregues pe los carabinelros locals à Chefia do Serviço de Polícia Militar, ค1s. 9.

Foram ouvidas, na instrução criminal, tres testemumas numerárias. Uma, GALII SIIVIO, declarou : "que devido à escuridão existente, quer na estrada, seja na casa da familla CAN TFLLI, não guardou a flsionomia do soldado que, com o depoente, te ve as ocorrências narradas em seu depolmento, fls. $67 v$. As restan tes assist1ram $\dot{a}$ confissão dos acusados, no inquérito, fls. 68 e $68 v$

Depuzeram ainda; além da ofendida, duas testemunhas Informantes: CANTELII TONINA reconheceu, nos dols acusados, as pes soas que estiveram, em sua casa, às 16 e 20 horas, praticando os atos constantes das declarações anterlores, fls. 66, CANTELII STEFFANO, que se exprimiu assim, a fls. 67 : "que embora terha aberto a porta para os soldados brasileiros que entraram em sua casa, não pode afirmar que os referidos soldados sejam os denunclados presentes, vistos como a casa do declarante se achava mal 1luminada".

Os acusados revelaram, no cometimento de tão graves infrações, ocorridas em zona de efetivas operações militares, fls. 58, absoluta falta de senso moral. Sua notícla causa dolorosa im pressão em todos os espirftos. A infortunada MARGELII se viu des pojada de sua honra sexual, em plena mocldade, e um homem tombou sem vida, por gesto meramente sanguinário. 
Es tatue o Código da Justiça Militar, que o art.47 do decreto-1e1 6.396, de 1 de abril de 1944 , manda observar no que não colidir com êsse diploma:

Art.182. Nos casos em que possa ser aplicada pena de morte ou de trinta anos de prisão, a confissão, nos têrmos do artigo anterior (se IIvre $\theta$ acorde com as circunstâncias do fa to), suje1ta o réu à pena imediatamente me nor, se não houver outra prova do crime.

o Código Penal Militar prescreve:

Art. 62. São circunstâncias que sempre ate nuam a pena:

IV - ter o agente:

d) confessado espontâneamente, perante au toridade, a autoria do crime, ignorada. ou imputada a outrem.

Acrescenta o $\$ 1^{\circ}$ do mesmo dispositivo - " nos crimes em que a pe na máxima é de morte ou de reclusão por vinte anos, ao juiz é facul tativo atender ou não às circunstâncias atenuantes enumeradas no ar tigo".

Não mais vigora, em face do exposto em último lu gar, o preceito do art. 182 do Código de Justiça Militar, que não autorizava a aplicabilidade da pena de morte, com apoio exclusivo na confissão do delinquente.

Atualmente, é permitido decretá-la em tal hipótese, sem amparo em prova de outra natureza, que, allás, existe no proces so, embora de testemunha informante, mas cujo depoimento se ajusta 
às clrcunstâncias do fato.

E a conclusão que emerge do $\S 1^{\circ}$ do art.62, que faculta ao juiz desprezar a atenuante da confissão da autoriade crime, Ignorada ou Imputada a outrem, quando se tratar de delito pu nido, no máximo, com a pena de morte ou de reclusão por 20 anos, na turalmente para que possa aplicar esta ou aquela, mesmo se os autos não fornecerem outros elementos de criminalidade.

Nem a atenuante do art. 62 , n. IV, alinea $\underline{\mathrm{d}}$, milita em favor dos acusados, segundo mostram os tóplcos, adian to transcritos, do offcio do Sr. Major Chefe do Serviço de Polf́cia Mi11tar, a fls. 9:

Pelos Indicios $\theta$ provas conseguidas surgirem como suspeitos $\theta$ multo provaveis autores do atentado os soldados ADÃO DAMAGENO PAZ \& LUIZ BERNARDO DE MO RAIS, que, trazidos a esta repartição para serem a careados com a vitima da violação carnal, MARGBLLI GIOVANINA, e com as testemunhas CANTELLI TONINA SIIVIO GALII, foram por êstes reconhecidos como os verdadeiros autores dos crimes cometidos. Presos e interrogados, confessaram sem hesitação os crimes que praticaram, tendo de suas declarações si do tomados os respectivos termos.

Quem, de qualquer modo, concorre para o crime, incide nas penas a êste cominadas (art. 33 do Código Penal Militar).

o soldado DAMACENO $\dot{\theta}$, tambem, responsavel pola morte de VIVARELII LEONARDO. Fle e BIRNARDO pactuaram a 1da à casa de MARGELII. Salram, do Quartel, armados de metralhadoras por 
tateis. Fo1 BIRRARDO quem apagou a luz, a pedido de DAMAGENO, e " permaneceu de guarda na porta", afim de auxillar o co-partfcipo . BERNARDO matou, precisamente no momento em que DAMAGENo violentava a Infeliz jovem. Houve, assim, a concorrencia criminosa de que cog1ta o menclonado art. 33, e que pressupõe, como se verlficou na espécie, e adverte Costa e Silva, em Código Penal, vol. $1^{\circ}$, pag. 199. certo liame psicológico entre os individuos que nela tomaram parte.

Opino pela confimação da sentença apelada.

CAPITAL FFEDERAL, 5 de março de 1945 .

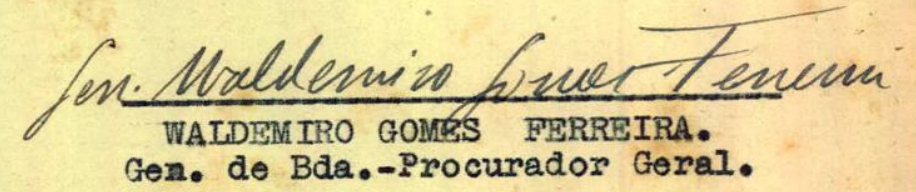




\section{XXI}

CÓPIA - BOLETIN INTERNO DA 1a. D. I. E., ne 75, de 16-III-945, ITEM XXII - "COMUTAÇÃO DE PENA - TRANSCRIÇÃO DE RADIOGRA MA - Este Cmdo. recebeu do Chefe do Gab inete do Exmo.Sr. Ministro o seguinte radiograma de 13 do corrente: "Nr... 48-F. Complemento rádio 46-F, de 9 corrente, transcrevo despacho Sr. Presidente República comunicação acórdão Conselho Supremo: Pela comutação pena máxima de reclusão. Si o Comandante em Chefe da F. E. B. não considerou necessário mandar executar desde logo a pena, como the pormitia o parágrafo único do artigo 41 do Código Penal Militar si o exigisse o interesse da ordem e da discipli na militar, é de se concluir que esse interesse e essa or dem não sorão afetadas com a comutação da pena. Esta, on tretanto, só se justiflca como ato de graça. Peço confir mar recobimento deste rádio". Coupé́ cou

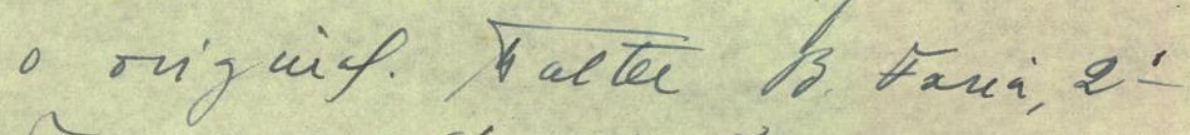
Gercuta, ó crival.

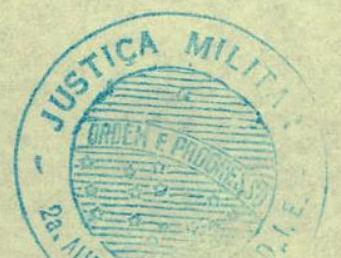


XXII

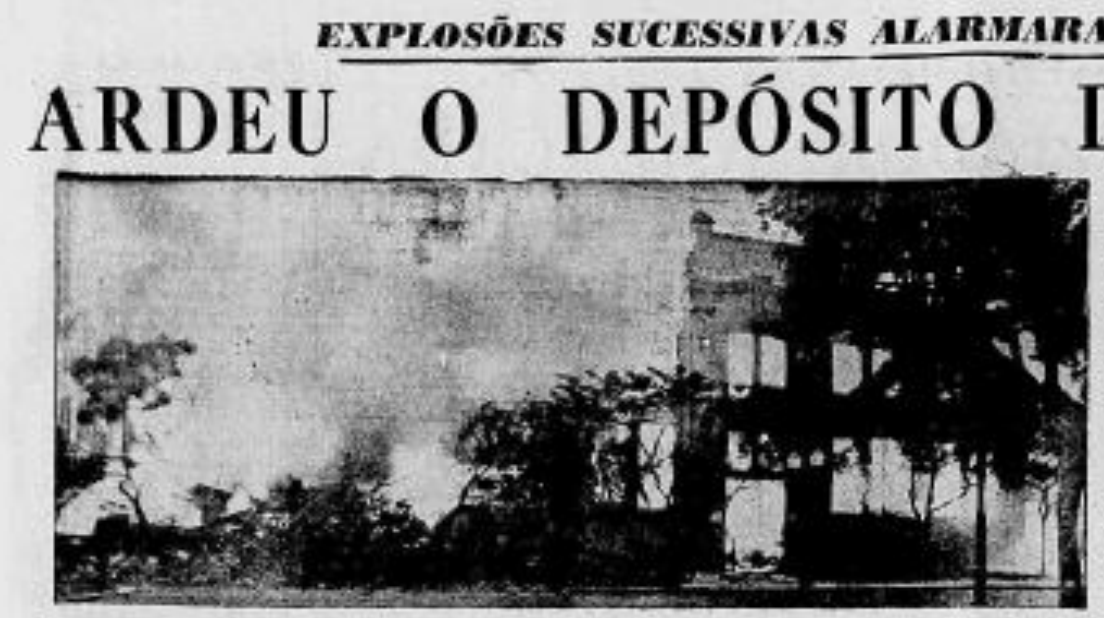

EXPLOSÖES SUCESSIVAS ALMTMARAM, ONTEM, A CIDADE

Divocarioca

(2.2.).

DE INFLAMAVEIS PROVOCANDO PANICO E FAZENDO VITIMAS

Parturientes Internadas na Prō-Matre Abandonaram os Leitos, em Fuga, e Soldados se Jogaram da "Cantina Dos Combatentes" a Rua

AO LADO DO TRAGICO, ESPETA CULOS COMOVENTES - QUEBRADAS TODAS AS VIDRAÇAS NAS IMEDIACCOES - 05 PREJUIZOS DA FIRMA DIAS CARCIA \& CLA. - A ACAO RAPIDA DOS BOMBEI-

POR CRIME DE VIOLENCIA CAR NAL E HOMICIDIO

DOIS SOLDADOS BRASILEIROS IAM SER FUZILADOS NO "FRONT"

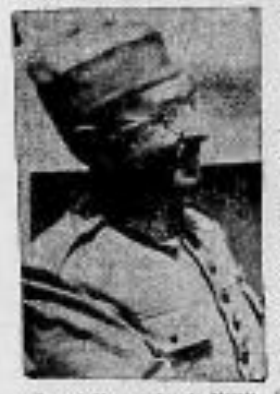

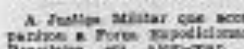

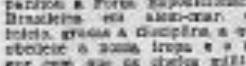

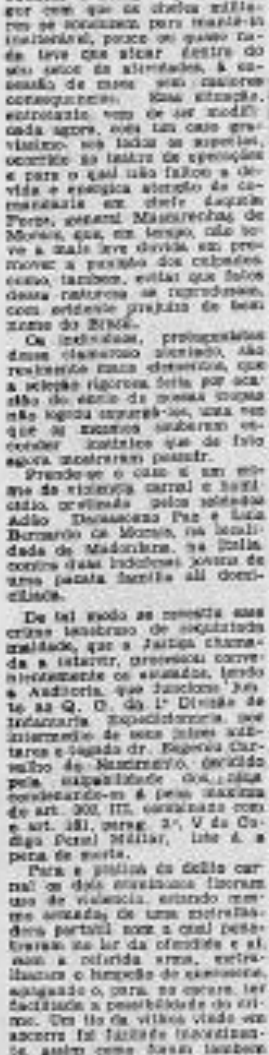

0 PRESIDENTE DA REPUBLICA, POREM COMUTOU A PENA PARA TRINTA ANOS DE PRIST̃O COM TRABALHOS - ENERGICAS PROVIDENCIAS DAS AUTORIDADES MILITARES
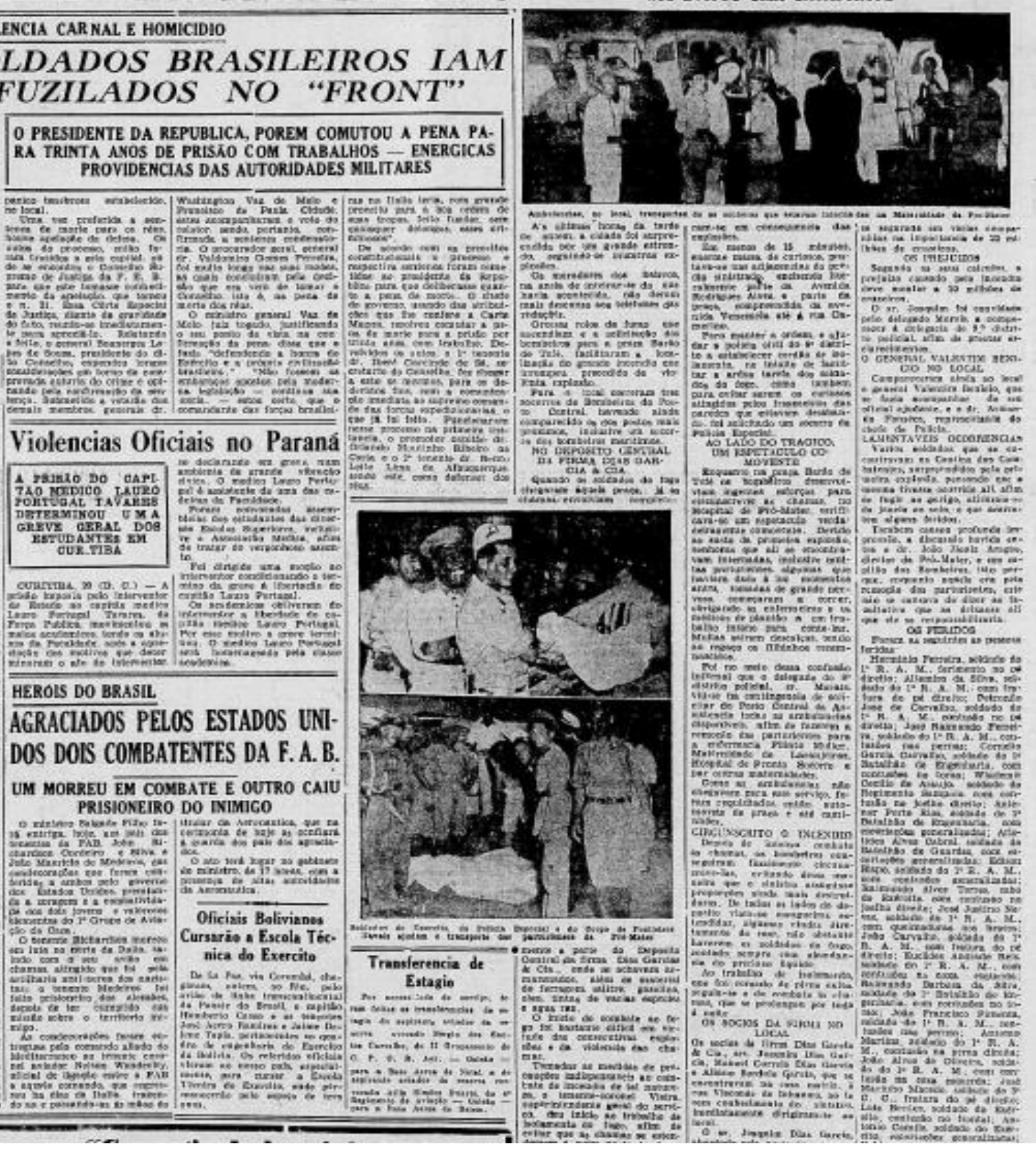


\section{XXIII}

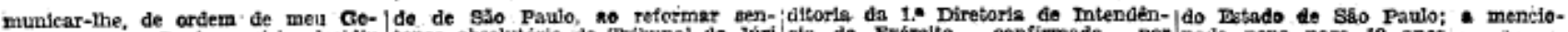
murno que o Goveno sirio deciafu veruo, que Conyencho Internasional para a unificaçáo de certas regras relativas acs priviléglos o liapotseas marítinas e ao protocolo de assiasturn, firmados

Mutto the agradeceria tomar conhecimento desta miti-la aos paises stualmente ligad

Queira 'aceltar, Excelência, or protestos de minha mui alta

A Sua Excelencia o Senhor Paul van zeeland, Ministro das Neźsclos Estrangeiros
Bruxelas.

\section{MINISTER IO D A \\ JUSTIÇA E NEGóCIOS INTERIORES}

da Comarca de rirajü, preenche ss / teordâo do Conselho Superior de Jus-

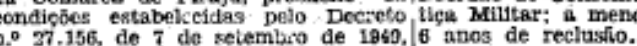

relativo $A$ concess"o da zraça em 60 mada pena parn 6 anos.

Atendendo a que o sentenciado An-

Atendendo que Manuel Jose Noguelra, condenado a pens de 21 anos tânio Batiata da silva já cumpriu mais de 2 anos e 1 mes da pena de fol concenado, como ineurso no artigo 121, do Tribunal do Jüri da Co mitrea de sio Josquin do Monte, Estado de Pernambuco:

Atendendo a que Antonio José Cactano, condenado à pena de 10 anos de reclusso, como incurso no artigo 121 do Código Penal, por declsśo do Tribunal do Júri do Distrito Federal. confirmada por Acóncaso do Tribumal te 7 de setembec de 1949 , relalivo de 7 de setembre de 1949 , relakivo DBCRETOS $\mathrm{DE}_{1951} 22$ DE MAIO çivo ao Ano Santo: a met
para 6 anos de reclusio.

A vista do parecer favoravel do Sho Paulo, e atendendo a que o sentenctado Belisário 1rança Carrapich da cumpriu mais de 2 anos e 11 mese da pena de 11 anos a 6 meses de re
clusso, a que fol condenado, com

o Presidente da República resolve: Coxuras:

Incurso no art. 121, "caput"" do Códe Justica daquele Batado, que refor-

Grando da etributicho que the confere - art. $87, n \cdot X I X$, da Constifúg̣áo A vista do parecer favoravel do Pernambraco o stendendo a que o sen cumpriu mals de 4 anos e 10 meses penariu de 2 anos 06 meses de reclușio, a que fol condenacio como penal. por decisio do Tribunal do Júr a Comarca de Recife, confirmada po: quele Estado: a mencínana pena quele Bstado: 6 anos de reclusio.

A vista do que consta do processo n. 4.041, de 1948, do Ministario da a sentencisdo Adetmar Gomes de Meneses, condenado à pena de 15 anos de rechusio, como tneurso no artsd com o art, 40, lnclso rv, ceta a, fine, do Cóligo Penal, por decisá $\mathrm{Re}$ Trife, confirmads poe acórdáa do Tribunal de Justica do Estado de Per-

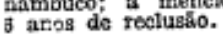

Atendendo a que o sentenctado Ademar Joes Pinto je eurppria mals inos de roclusío. a que fol condenado, como incurso no art. 121 do
Cúdiro Penal, por decisão do Tribunal do Júri do Distrito Federal, confirmada por acordio do Tribunal unos.

A vista do que consta do processo mou, elevsndo 2 persa, decisio do TYbunal do Júr a da Comarea de Proanos de reclusiso, dos quals, dsda su
situagio cumprirs trés quartos situaglio cumprirs tiés quartos no comportamento carcerário, conforme apuractio oportuna.

Atenderido a que Ploriano silvelr rasrte, condensac, a pena de 6 anos no artigo 121, parígrafo 1.\% do $06-$ digo Jenal, por deciosio do do 'Trlbuma Estado â Rio Grantic do Sul, preenche as conditcbes eatabelecidas pelo

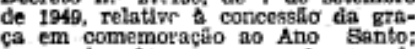
reclusão.

Atendencio a quo Jos6 Teotanio ano de detencio peio reclusiso Justbca do Estado do Fio de Janeiro so reformar, em grau de revisio, a primitiva sentança que lhe impusera

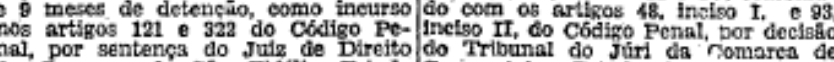
an Comares dé são Pidelis, Eatado Camaratuba, Estado de Pernarabuoo: do Rio de Janeiso, preenche as eonmero 27.156 , de 7 de setembro de 1949 memoracio an Ano Santo a mencioAtendendo a que o sentenciado tus Alves da Gilva, condenado a 24 ano

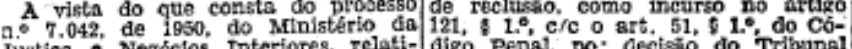

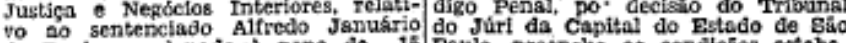
te Paula, condenado a pena de is Paulo, preenche as condicóes estabe-

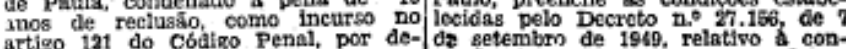
artigo 121 do Cóalgo Penal, por de- de setembro de 1969, relativo a con$\rightarrow$ de Afonso Cláudio, oonfirmada por Acordedio do Espirito Santo: a mencioj.

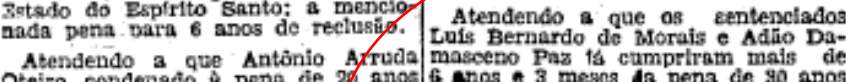

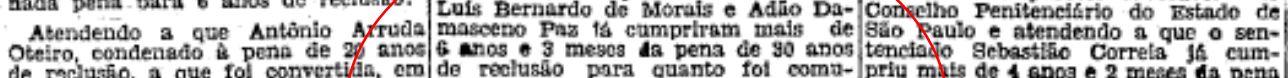
evisio a de $3 n$ anos de prifio ce- tada, por decreto de 12 de mareo de priu mits de 1 anos e 2 metes fa dena

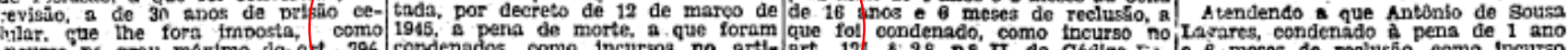

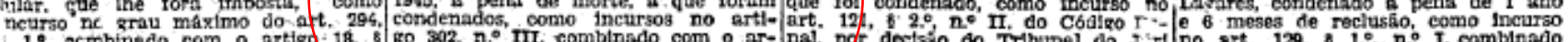

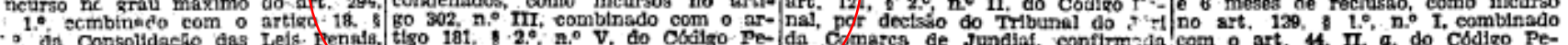

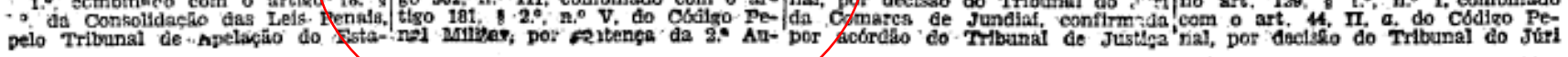

A pista do parecer do Consetho Penituenciario ao Estacio de PernamirsSeverino Jose da sue o sentenciado mals de 6 anos e 8 meses da pena de sto, a que fol condenado, como incur50 no art. 280 , em referencla ao artrgos 57 e 156, \&.2. $20^{\circ}$ do Código Penal Mulitar, por decisio do guperior Tri29 anos e 4 meses de reclusuro, imposConselho Permanente de Justica, da Auditoria da 7,4 Rcgía Midens para 15 anos de reclusáo. Atendendo a que severino Cândido anos de prisio celular. como incurso no art. 224, $22^{\circ}$, dn Consolidackio das de Apelaçắ do Estado do Ceark, que reformou Gecisaio absolutórta do Tr1cavel, proenche as comarca de Caslecidss pelo Decreto n. Z7.156, de cessio da graça $\mathrm{em}$ commoraciio so Ano santo; a menctonada pena pari anos de recluséo.

Atondendo a que o sentenciado Whilson Perefra de Melo jo cumptiu anos de reclusilio, a que fo' condena-

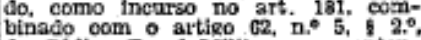
do C6́ligo Penal Miskar. por antenitse; a menetonacia pena para 12 nos de reclusilo.

\section{InLOLTak:}

Atendendo a que Ablio Arruda cluspos, eomo fineurso no artigo 128 sentence do Jula de Direito da por Vara Criminal da Comarca de Samtos, Eatado de Sajo Paulo, preenche creto r. 27.156 , de 7 de setembro de em comemoracío no Ano
resto da mencionada pena.

Atendendo a que Antonso Flrmino anos de roclusso. como tneurso no artigo 121 do Cótigo Penal, por decistio do Tribunal do Júr da Comarca de do Norte, proenche as condicōes estabelecidas pelo Decreto n. 27.156 . conoessto da graça em comemoracúo no Ano Ban

Atendendo a que o sentenctado máso comes da silva fí cumpriu de 16 anos e e meses de recinesio, para quanto fol comutada a de 22 curso no art. 294. 1.9. da Consolido crio das Lets Peniais, por Acorda de Pernambaco, que reformou àecisúo do Tribunal do Júr dia Comirea de Atendendo s que André Paulino, 7 meses a pena total dic 2 anos e nos arts. $129,56.0 .121 .530^{\circ} 04$. 129, $60^{\circ} \mathbf{e}^{\circ}$ do Código Penal, a marea de Mímoso do Sul, Estado d. Espirito Sarto, preenche ss conTo 27.150, da 7 de setermber re concessso da graca 